\title{
Amide $\alpha, \beta$-Dehydrogenation Using Allyl-Palladium Catalysis and a Hindered Monodentate Anilide
}

\author{
Yifeng Chen, Aneta Turlik, and Timothy R. Newhouse* \\ Department of Chemistry, Yale University, 275 Prospect St., New Haven, Connecticut \\ 06520-8107
}

\section{Supporting Information}

\section{Table of Contents}

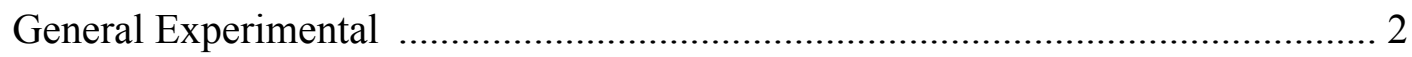

Experimental Procedures and Characterization Data for Amide Substrates ............ 3-17

Experimental Procedures and Characterization Data for Anilines .......................... 18-22

Experimental Procedures and Characterization Data for Amide Products .............. 23-59

Experimental Procedures for Nitrile and Ester Products ........................................ 60-61

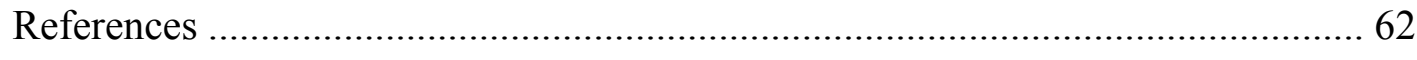

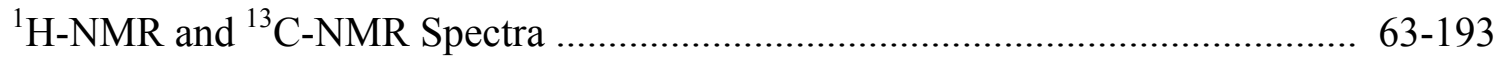




\section{General Experimental}

All reactions were carried out under an inert nitrogen atmosphere with dry solvents under anhydrous conditions unless otherwise stated. All reaction solvents were purified using a Seca solvent purification system by Glass Contour. Reagents were used as received without further purification, unless otherwise stated. Diisopropylamine, triethylamine, $N, N$-diisopropylethylamine and dicyclohexylamine were purified by distillation over $\mathrm{CaH}_{2}$. Reactions were monitored by thin-layer chromatography (TLC) carried out on $0.25 \mathrm{~mm}$ E. Merck silica gel plates (60F-254) using UV light as the visualizing agent and potassium permanganate, iodine, an acidic solution of $p$ anisaldehyde, and Seebach stain with heat as developing agents. All new compounds were characterized by means of ${ }^{1} \mathrm{H}-\mathrm{NMR},{ }^{13} \mathrm{C}-\mathrm{NMR},{ }^{19} \mathrm{~F}-\mathrm{NMR}$ FT-IR, and HR-MS. Melting points were obtained for all solids on a Mel-Temp capillary melting point apparatus. Copies of the ${ }^{1} \mathrm{H}$ - and ${ }^{13} \mathrm{C}$-NMR spectra can be found at the end of the Supporting Information. NMR spectra were recorded using a Varian $400 \mathrm{MHz}$ NMR spectrometer, a Varian $500 \mathrm{MHz}$ NMR spectrometer or a Varian $600 \mathrm{MHz}$ NMR spectrometer. All ${ }^{1} \mathrm{H}-\mathrm{NMR}$ data are reported in $\delta$ units, parts per million (ppm), and were calibrated relative to the signals for residual chloroform $(7.26 \mathrm{ppm})$ in deuterochloroform $\left(\mathrm{CDCl}_{3}\right)$ or residual DMSO $(2.50 \mathrm{ppm})$ in deuterodimethyl sulfoxide ( $\left.\mathrm{d}_{6}-\mathrm{DMSO}\right)$. All

${ }^{13} \mathrm{C}$-NMR data are reported in ppm relative to $\mathrm{CDCl}_{3}$ (77.16 ppm) or $\mathrm{d}_{6}$-DMSO (39.52 ppm) and were obtained with ${ }^{1} \mathrm{H}$ decoupling. The following abbreviations or combinations thereof were used to explain the multiplicities: $\mathrm{s}=$ singlet, $\mathrm{d}=$ doublet, $\mathrm{t}=$ triplet, $\mathrm{q}=$ quartet, quint $=$ quintet, sext $=$ sextet, sept $=$ septet, $\mathrm{br}=$ broad, $\mathrm{m}=$ multiplet, $a=$ apparent. All IR spectra were taken on a FT-IR/Raman Thermo Nicolet 6700. High resolution mass spectra (HRMS) were recorded on a Bruker micrOTOF mass spectrometer using ESI-TOF (electrospray ionization-time of flight). 


\section{Substrates Synthesis}

Amides and lactams $\mathbf{1 b},{ }^{1} \mathbf{1 c},{ }^{2} \mathbf{1} \mathbf{m},{ }^{3} \mathbf{1 q},{ }^{4} \mathbf{1 r},{ }^{5} \mathbf{1 t},{ }^{6} \mathbf{1} \mathbf{u},{ }^{7} \mathbf{1},{ }^{8} \mathbf{1} \mathbf{x}^{9}$ were synthesized according to the published procedures.

\section{General procedure A for amide synthesis}

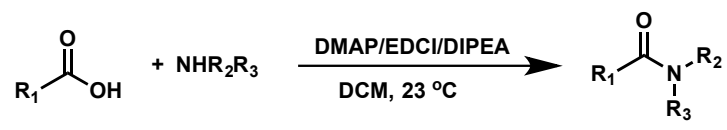

To a solution of acid in $\mathrm{CH}_{2} \mathrm{Cl}_{2}(0.2 \mathrm{M})$ was added EDCI (1.1 equiv), DMAP (0.1 equiv), DIPEA (3.0 equiv), and amine (1.1 equiv). The mixture was stirred for 12 to 48 hours at $23{ }^{\circ} \mathrm{C}$. Water was added, and the organic phase was separated. The aqueous phase was extracted with $\mathrm{CH}_{2} \mathrm{Cl}_{2} 3$ times and the combined organic layers were washed with brine, dried over anhydrous $\mathrm{Na}_{2} \mathrm{SO}_{4}$, filtered, and concentrated under reduced pressure by rotary evaporation. Purification by flash column chromatography afforded the corresponding amide.

\section{General procedure B for amide synthesis}

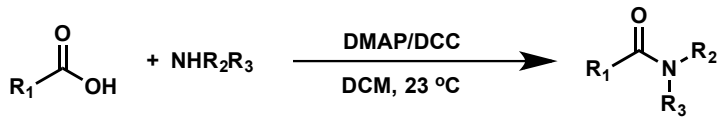

To a solution of acid in $\mathrm{CH}_{2} \mathrm{Cl}_{2}(0.2 \mathrm{M})$ was added DCC (1.1 equiv), DMAP (0.1 equiv), and amine (1.1 equiv). The mixture was stirred for 24 to 72 hours at $23{ }^{\circ} \mathrm{C}$. After filtration, the mixture was concentrated under reduced pressure by rotary evaporation. Purification by flash column chromatography on silica gel afforded the corresponding amide.

\section{General procedure $\mathbf{C}$ for amide synthesis}

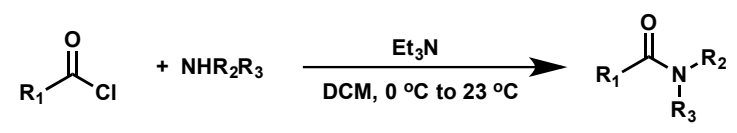

To a $0{ }^{\circ} \mathrm{C}$ solution of acyl chloride (1.0 equiv) in $\mathrm{CH}_{2} \mathrm{Cl}_{2}(0.2 \mathrm{M})$ was added anhydrous $\mathrm{Et}_{3} \mathrm{~N}$ (3.0 equiv) and and amine (1.1 equiv). After stirring for 5 min at $0{ }^{\circ} \mathrm{C}$, the mixture was stirred for overnight at $23{ }^{\circ} \mathrm{C}$. Sat. aq. $\mathrm{NH}_{4} \mathrm{Cl}$ was added, and the organic phase was separated. The aqueous phase was extracted with $\mathrm{CH}_{2} \mathrm{Cl}_{2} 3$ times and the 
combined organic layers were washed with brine, dried over anhydrous $\mathrm{Na}_{2} \mathrm{SO}_{4}$, filtered, and concentrated under reduced pressure by rotary evaporation. Purification by flash column chromatography on silica gel afforded the corresponding amide.

\section{$N, N$-dibenzyl-3-methylbutanamide 1a}

${ }_{\mathrm{Me}} \stackrel{\text { Me }}{\mathrm{CONBn}_{2}}$ General procedure A was followed with a reaction time of 24 hours. $1 \mathrm{a}$ Purification by flash column chromatography on silica gel (hexanes/EtOAc $=8: 1$ to $5: 1)$ afforded the title product as a viscous colorless oil in $79 \%$ yield (11.1 g). $\mathbf{R}_{\mathbf{f}}$ $=0.41$ (hexanes/EtOAc $=4: 1) ;{ }^{1} \mathbf{H}$ NMR $\left(400 \mathrm{MHz}, \mathrm{CDCl}_{3}\right): \delta 7.37(\mathrm{t}, J=7.6 \mathrm{~Hz}, 2 \mathrm{H})$, 7.33-7.22 (m, 6H), 7.16 (d, $J=7.6 \mathrm{~Hz}, 2 \mathrm{H}), 4.62(\mathrm{~s}, 2 \mathrm{H}), 4.46$ (s, 2H), 2.33-2.26 (m, $3 \mathrm{H}), 1.00(\mathrm{~d}, J=6.4 \mathrm{~Hz}, 6 \mathrm{H}) ;{ }^{13} \mathbf{C}$ NMR $\left(100 \mathrm{MHz}, \mathrm{CDCl}_{3}\right): \delta 173.0,137.7,136.7$, 128.9, 128.6, 128.3, 127.6, 127.4, 126.4, 49.9, 48.0, 42.1, 25.8, 22.8; IR ( $\left.\mathrm{cm}^{-1}\right): 2957$, 1641, 1495, 1417, 1207, 1078, 960, 730, 696; ESI-HRMS (m/z): $[\mathrm{M}+\mathrm{H}]^{+}$calc'd for $\mathrm{C}_{19} \mathrm{H}_{24} \mathrm{NO}$ : 282.1852; found: 282.1841 .

\section{tert-Butyl 4-(3-phenylpropanoyl)piperazine-1-carboxylate 1d}

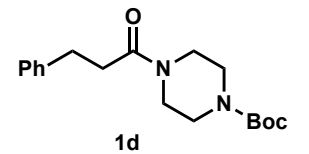

General procedure $\mathrm{C}$ was followed with a reaction time of 14 hours. Purification by flash column chromatography on silica gel (hexanes/EtOAc $=3: 1$ to 2:1) afforded the title product as a white solid in $80 \%$ yield $\left(2.54\right.$ g). M.P. $=66-69{ }^{\circ} \mathrm{C} ; \mathbf{R}_{\mathbf{f}}=0.40($ hexanes $/$ EtOAc $=1: 1) ;{ }^{1} \mathbf{H}$ NMR (400 MHz, $\left.\mathrm{CDCl}_{3}\right): \delta 7.30-7.26(\mathrm{~m}, 2 \mathrm{H}), 7.22-7.18(\mathrm{~m}, 3 \mathrm{H}), 3.58(\mathrm{t}, J=5.2 \mathrm{~Hz}$, 2H), 3.38-3.28 (m, 6H), 2.97 (t, $J=7.2 \mathrm{~Hz}, 2 \mathrm{H}), 2.62$ (t, $J=8.0 \mathrm{~Hz}, 2 \mathrm{H}), 1.45$ (s, 9H); ${ }^{13} \mathrm{C}$ NMR (100 MHz, $\left.\mathrm{CDCl}_{3}\right): \delta 170.9,154.6,141.1,128.6,128.5,126.4,80.4,45.4$, 41.5, 35.2, 31.6, 28.5; IR $\left(\mathrm{cm}^{-1}\right): 2978,1682,1634,1459,1361,1175,1071,742$; ESIHRMS (m/z): $[\mathrm{M}+\mathrm{H}]^{+}$calc'd for $\mathrm{C}_{18} \mathrm{H}_{27} \mathrm{~N}_{2} \mathrm{O}_{3}: 319.2016$; found: 319.2011 .

\section{$N, N$-dibenzyl-3-phenylpropanamide $1 \mathrm{e}$}

$\begin{array}{ll}\mathrm{I}_{\mathrm{NBn}_{2}} & \text { General procedure } \mathrm{C} \text { was followed with a reaction time of } 16 \text { hours. } \\ \text { Purification by flash column chromatography on silica gel (hexanes/EtOAc }\end{array}$ $=10: 1$ to $5: 1)$ afforded the title product as a white solid in $80 \%$ yield $(2.63 \mathrm{~g}) .{ }^{1} \mathbf{H}$ NMR (400 MHz, $\left.\mathrm{CDCl}_{3}\right): \delta 7.37-7.26(\mathrm{~m}, 8 \mathrm{H}), 7.23-7.19(\mathrm{~m}, 5 \mathrm{H}), 7.10(\mathrm{t}, J=6.8 \mathrm{~Hz}, 2 \mathrm{H})$, 
$4.62(\mathrm{~s}, 2 \mathrm{H}), 4.39(\mathrm{~s}, 2 \mathrm{H}), 3.07(\mathrm{t}, J=8.0 \mathrm{~Hz}, 2 \mathrm{H}), 2.74(\mathrm{t}, J=8.0 \mathrm{~Hz}, 2 \mathrm{H}) ;{ }^{13} \mathbf{C}$ NMR $\left(100 \mathrm{MHz}, \mathrm{CDCl}_{3}\right): \delta 172.8,141.3,137.4,136.5,129.1,128.7,128.6,128.6,128.4$, $127.7,127.5,126.4,126.3,50.0,48.4,35.2,31.7$. The spectral data are consistent with those reported in the literature. ${ }^{10}$

\section{$N, N$-dibenzyl-3-(4-methoxyphenyl)propanamide $1 f$}

General procedure B was followed with a reaction time of 48 hours.
Meo $(\mathrm{DCM} / \mathrm{MeOH}=1: 0$ to $10: 1)$ afforded the title product as a white solid in $43 \%$ yield $\left(1.46\right.$ g). M.P. $=72-74{ }^{\circ} \mathrm{C} ; \mathbf{R}_{\mathbf{f}}=0.28$ (hexanes $/$ EtOAc $\left.=4: 1\right) ;{ }^{1} \mathbf{H}$ NMR $\left(400 \mathrm{MHz}, \mathrm{CDCl}_{3}\right): \delta 7.35-7.26(\mathrm{~m}, 6 \mathrm{H}), 7.18(\mathrm{~d}, J=6.8 \mathrm{~Hz}, 2 \mathrm{H}), 7.11-7.06(\mathrm{~m}$, $4 \mathrm{H}), 6.80$ (t, $J=8.4 \mathrm{~Hz}, 2 \mathrm{H}), 4.60$ (s, 2H), 4.37 (s, 2H), 3.78 (s, 3H), 3.00 (t, $J=8.0 \mathrm{~Hz}$, $2 \mathrm{H}), 2.69(\mathrm{t}, J=8.0 \mathrm{~Hz}, 2 \mathrm{H}) ;{ }^{13} \mathbf{C}$ NMR $\left(100 \mathrm{MHz}, \mathrm{CDCl}_{3}\right): \delta 172.9,158.1,137.5,136.6$, 133.3, 129.8, 129.0, 128.7, 128.4, 127.7, 127.5, 126.4, 114.0, 55.4, 50.0, 48.4, 35.4, 30.9. IR $\left(\mathrm{cm}^{-1}\right): 2920,1640,1509,1423,1243,1082,826$; ESI-HRMS (m/z): $[\mathrm{M}+\mathrm{H}]^{+}$calc'd for $\mathrm{C}_{24} \mathrm{H}_{26} \mathrm{NO}_{2}$ : 360.1958 ; found: 360.1959 .

\section{$N, N$-dibenzyl-3-(p-tolyl)propanamide $1 \mathrm{~g}$}

General procedure $\mathrm{B}$ was followed with a reaction time of 48 hours.
Pe (hexanes/EtOAc $=10: 1$ to $3: 1$ ) afforded the title product as a white solid in 59\% yield (2.03 g). M.P. $=43-45{ }^{\circ} \mathrm{C} ; \mathbf{R}_{\mathbf{f}}=0.45$ (hexanes $/$ EtOAc $\left.=4: 1\right) ;{ }^{1} \mathbf{H}$ NMR (400 MHz, $\left.\mathrm{CDCl}_{3}\right): \delta 7.38-7.29(\mathrm{~m}, 6 \mathrm{H}), 7.21(\mathrm{~d}, J=7.6 \mathrm{~Hz}, 2 \mathrm{H}), 7.13-7.05(\mathrm{~m}$, $6 \mathrm{H}), 4.63$ (s, 2H), 4.40 (s, 2H), 3.04 (t, $J=8.0 \mathrm{~Hz}, 2 \mathrm{H}), 2.73$ (t, $J=8.0 \mathrm{~Hz}, 2 \mathrm{H}), 2.34$ (s, $3 \mathrm{H}) ;{ }^{13} \mathrm{C}$ NMR (100 MHz, $\left.\mathrm{CDCl}_{3}\right): \delta$ 172.9, 138.1, 137.4, 136.5, 135.7, 129.2, 129.0, 128.6, 128.5, 128.4, 127.7, 127.5, 126.4, 49.9, 48.3, 35.3, 31.3, 21.1; IR ( $\left.\mathrm{cm}^{-1}\right): 2928$, 1635, 1494, 1228, 1007, 810; ESI-HRMS $(\mathrm{m} / \mathrm{z}):[\mathrm{M}+\mathrm{H}]^{+}$calc'd for $\mathrm{C}_{24} \mathrm{H}_{26} \mathrm{NO}$ : 344.2009; found: 344.2030 . 


\section{$N, N$-dibenzyl-3-(4-(trifluoromethyl)phenyl)propanamide $1 \mathrm{~h}$}

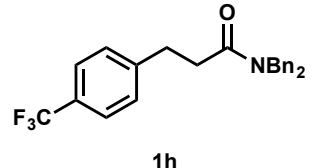

1h

General procedure B was followed with a reaction time of 48 hours.

Purification by flash column chromatography on silica gel (hexanes/EtOAc $=10: 1$ to $7: 1$ ) afforded the title product as a white solid in 35\% yield (1.37 g). M.P. $=46-49{ }^{\circ} \mathrm{C} ; \mathbf{R}_{\mathbf{f}}=0.34$ (hexanes/EtOAc $\left.=4: 1\right) ;{ }^{1} \mathbf{H}$ NMR (400 MHz, $\left.\mathrm{CDCl}_{3}\right): \delta 7.51(\mathrm{~d}, J=8.4 \mathrm{~Hz}, 2 \mathrm{H}), 7.36-7.28(\mathrm{~m}, 8 \mathrm{H}), 7.18(\mathrm{~d}, J=6.0$ $\mathrm{Hz}, 2 \mathrm{H}), 7.05(\mathrm{~d}, J=6.4 \mathrm{~Hz}, 2 \mathrm{H}), 4.61(\mathrm{~s}, 2 \mathrm{H}), 4.40$ (s, 2H), 3.11 (t, J= $7.6 \mathrm{~Hz}, 2 \mathrm{H}), 2.73$ $(\mathrm{t}, J=7.6 \mathrm{~Hz}, 2 \mathrm{H}) ;{ }^{13} \mathbf{C}$ NMR $\left(100 \mathrm{MHz}, \mathrm{CDCl}_{3}\right): \delta 172.3,145.5,137.3,136.4,129.1$, $129.0,128.7,128.4,127.8,127.6,126.3,125.5$ (q, $\left.J_{C-F}=3.8 \mathrm{~Hz}\right), 124.4$ (q, $J_{C-F}=272.0$ $\mathrm{Hz}), 50.0,48.7,34.5,31.3 ;{ }^{19} \mathbf{F}$ NMR $\left(376 \mathrm{MHz}, \mathrm{CDCl}_{3}\right): \delta-62.3, \mathbf{I R}\left(\mathrm{cm}^{-1}\right): 2925,1644$, 1495, 1467, 1445, 1368, 1229, 1016, 834; ESI-HRMS $(\mathrm{m} / \mathrm{z}):[\mathrm{M}+\mathrm{H}]^{+}$calc'd for $\mathrm{C}_{24} \mathrm{H}_{23} \mathrm{~F}_{3} \mathrm{NO}$ : 398.1726; found: 398.1707.

\section{$N, N$-dibenzyl-3-(4-chlorophenyl)propanamide $1 \mathrm{i}$}

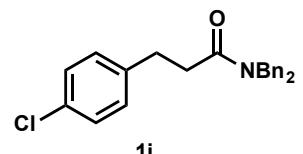

$1 \mathrm{i}$

General procedure B was followed with a reaction time of 48 hours.

Purification by flash column chromatography on silica gel (hexanes/EtOAc $=10: 1$ to $7: 1$ ) afforded the title product as a white solid in 89\% yield (3.15 g). M.P. $=74-76{ }^{\circ} \mathrm{C} ; \mathbf{R}_{\mathbf{f}}=0.33$ (hexanes/EtOAc $\left.=3: 1\right) ;{ }^{1} \mathbf{H}$ NMR $\left(400 \mathrm{MHz}, \mathrm{CDCl}_{3}\right): \delta 7.36-7.28(\mathrm{~m}, 6 \mathrm{H}), 7.23(\mathrm{~d}, J=8.4 \mathrm{~Hz}, 2 \mathrm{H}), 7.18(\mathrm{~d}, J=6.8$ $\mathrm{Hz}, 2 \mathrm{H}), 7.12$ (d, $J=8.4 \mathrm{~Hz}, 2 \mathrm{H}), 7.06$ (d, $J=6.8 \mathrm{~Hz}, 2 \mathrm{H}), 4.61$ (s, 2H), 4.39 (s, 2H), $3.03(\mathrm{t}, J=7.2 \mathrm{~Hz}, 2 \mathrm{H}), 2.70(\mathrm{t}, J=7.2 \mathrm{~Hz}, 2 \mathrm{H}) ;{ }^{13} \mathbf{C}$ NMR $\left(100 \mathrm{MHz}, \mathrm{CDCl}_{3}\right): \delta 172.4$, $139.8,137.3,136.5,132.0,130.0,129.1,128.7,128.6,128.4,127.7,127.5,126.3,50.0$, 48.5, 34.8, 30.9; IR $\left(\mathrm{cm}^{-1}\right):$ 2928, 1635, 1494, 1228, 1007, 810; ESI-HRMS (m/z): $[\mathrm{M}+\mathrm{H}]^{+}$calc'd for $\mathrm{C}_{23} \mathrm{H}_{23} \mathrm{CINO}$ : 364.1463; found: 364.1476 .

\section{$N, N$-dibenzyl-3-(2-bromophenyl)propanamide $1 \mathrm{j}$}

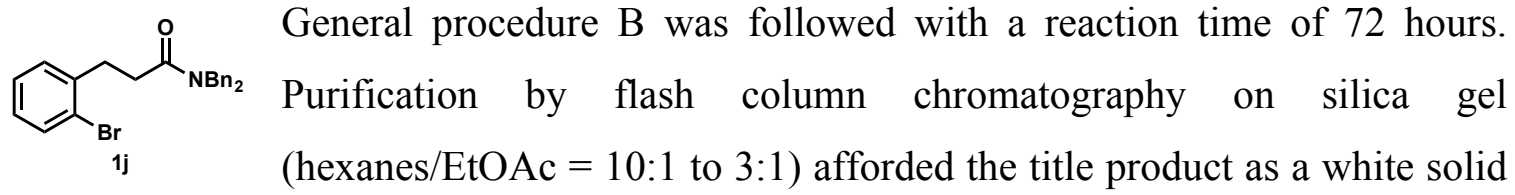
in $85 \%$ yield (3.41 g). M.P. $=46-48{ }^{\circ} \mathrm{C} ; \mathbf{R}_{\mathbf{f}}=0.45$ (hexanes $/$ EtOAc $\left.=4: 1\right) ;{ }^{1} \mathbf{H}$ NMR (400 $\left.\mathrm{MHz}_{\mathrm{CDCl}}\right): \delta 7.50(\mathrm{~d}, J=8.0 \mathrm{~Hz}, 1 \mathrm{H}), 7.36-7.26(\mathrm{~m}, 7 \mathrm{H}), 7.23-7.18(\mathrm{~m}, 3 \mathrm{H}), 7.11-$ 
$7.05(\mathrm{~m}, 3 \mathrm{H}), 4.62(\mathrm{~s}, 2 \mathrm{H}), 4.41$ (s, 2H), 3.19 (t, $J=8.0 \mathrm{~Hz}, 2 \mathrm{H}), 2.76(\mathrm{~d}, J=8.0 \mathrm{~Hz}, 2 \mathrm{H})$;

${ }^{13}$ C NMR (100 MHz, $\left.\mathrm{CDCl}_{3}\right): \delta 172.6,140.5,137.4,136.5,132.9,131.2,129.0,128.7$, 128.4, 128.1, 127.7, 127.7, 127.5, 126.5, 124.4, 50.0, 48.4, 33.2, 32.4; IR ( $\left.\mathrm{cm}^{-1}\right): 2941$, 1631, 1494, 1349, 1204, 1082, 729; ESI-HRMS $(\mathrm{m} / \mathrm{z}):[\mathrm{M}+\mathrm{H}]^{+}$calc'd for $\mathrm{C}_{23} \mathrm{H}_{23}{ }^{81}$ BrNO: 410.0937 ; found: 410.0966 .

\section{$N, N$-diethylhex-4-ynamide $1 \mathrm{k}$}

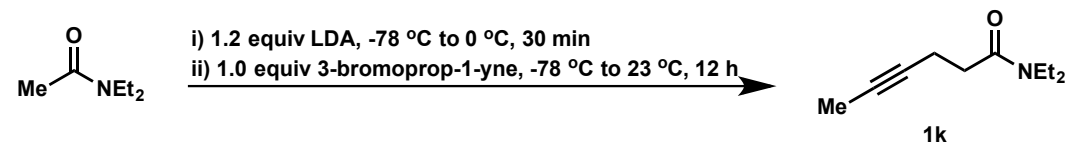

To a $0{ }^{\circ} \mathrm{C}$ solution of diisopropylamine $(0.51 \mathrm{~mL}, 3.6 \mathrm{mmol}, 1.2$ equiv $)$ in THF $(20 \mathrm{~mL}, 0.18 \mathrm{M})$ was added $n$-BuLi (2.5 M in hexanes, $1.4 \mathrm{~mL}, 3.6 \mathrm{mmol}, 1.2$ equiv) and the resulting solution was stirred for $30 \mathrm{~min}$. After the mixture was cooled down to -78 ${ }^{\circ} \mathrm{C}$, diethylacetamide $(0.45 \mathrm{~mL}, 3.6 \mathrm{mmol}, 1.2$ equiv) was added dropwise into the reaction mixture and the mixture became clear immediately. The resulting solution was moved into an ice-water bath and stirred for $30 \mathrm{~min}$. Then the mixture was moved to -78 ${ }^{\circ} \mathrm{C}$ cooling bath, and 1-bromo-2-butyne $(0.20 \mathrm{~mL}, 3.0 \mathrm{mmol}, 1.0$ equiv) was slowly added to the reaction mixture. The mixture was removed from the cooling bath, stirred for $12 \mathrm{~h}$ at $23{ }^{\circ} \mathrm{C}$, and was stopped by addition of sat. aq. $\mathrm{NH}_{4} \mathrm{Cl}(20 \mathrm{~mL})$. The organic phase was separated. The aqueous phase was extracted with EtOAc $(3 \times 20 \mathrm{~mL})$ and the combined organic layers were washed with brine $(30 \mathrm{~mL})$, dried over anhydrous $\mathrm{Na}_{2} \mathrm{SO}_{4}$, filtered and concentrated under reduced pressure by rotary evaporation. Purification by flash column chromatography on silica gel (hexanes/EtOAc $=5: 1$ to $3: 1$ ) afforded the title product as a colorless oil $(441 \mathrm{mg}, 88 \%) . \mathbf{R}_{\mathbf{f}}=0.17$ (hexanes $/$ EtOAc $\left.=4: 1\right) ;{ }^{1} \mathbf{H}$ NMR $\left(500 \mathrm{MHz}, \mathrm{CDCl}_{3}\right): \delta 3.36$ (q, $\left.J=7.0 \mathrm{~Hz}, 2 \mathrm{H}\right), 3.30$ (q, $\left.J=7.0 \mathrm{~Hz}, 2 \mathrm{H}\right), 2.51-2.44(\mathrm{~m}$, 4H), 1.75 (s, 3H), 1.17 (t, $J=7.0 \mathrm{~Hz}, 3 \mathrm{H}), 1.10$ (t, $J=7.0 \mathrm{~Hz}, 3 \mathrm{H}) ;{ }^{13} \mathbf{C}$ NMR $(125 \mathrm{MHz}$, $\left.\mathrm{CDCl}_{3}\right): \delta 170.6,78.4,76.0,42.0,40.3,32.8,15.1,14.4,13.2,3.6$; IR $\left(\mathrm{cm}^{-1}\right): 2973,2921$, 1634, 1481, 1431, 1268, 1139, 786; ESI-HRMS (m/z): $[\mathrm{M}+\mathrm{H}]^{+}$calc'd for $\mathrm{C}_{10} \mathrm{H}_{18} \mathrm{NO}$ : 168.1383; found: 168.1360 . 


\section{(E)-N,N-dimethyl-5-phenylpent-4-enamide 11}

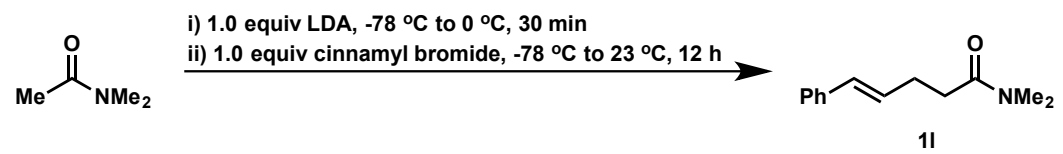

To a $0{ }^{\circ} \mathrm{C}$ solution of diisopropylamine $(2.1 \mathrm{~mL}, 15 \mathrm{mmol}, 1.0$ equiv) in THF (60 $\mathrm{mL}, 0.25 \mathrm{M})$ was added $n$-BuLi $(2.5 \mathrm{M}$ in hexanes, $6.0 \mathrm{~mL}, 15 \mathrm{mmol}, 1.0$ equiv) and the resulting solution was stirred for $30 \mathrm{~min}$. After the mixture was cooled down to $-78{ }^{\circ} \mathrm{C}$, dimethylacetamide (1.4 mL, $15 \mathrm{mmol}, 1.0$ equiv) was added dropwise into the reaction mixture and the mixture became clear immediately. The resulting solution was moved into an ice-water bath and stirred for $30 \mathrm{~min}$. Then the mixture was moved to $-78{ }^{\circ} \mathrm{C}$ cooling bath, and cinnamyl bromide $(2.2 \mathrm{~mL}, 15 \mathrm{mmol}, 1.0$ equiv) was slowly added to the reaction mixture. The mixture was removed from the cooling bath, stirred for $12 \mathrm{~h}$ at $23{ }^{\circ} \mathrm{C}$, and was stopped by addition of sat. aq. $\mathrm{NH}_{4} \mathrm{Cl}(50 \mathrm{~mL})$, the organic phase was separated. The aqueous phase was extracted with EtOAc $(3 \times 30 \mathrm{~mL})$ and the combined organic layers were washed with brine $(50 \mathrm{~mL})$, dried over anhydrous $\mathrm{Na}_{2} \mathrm{SO}_{4}$, filtered and concentrated under reduced pressure by rotary evaporation. Purification by flash column chromatography on silica gel (hexanes/EtOAc $=2: 1$ to $0: 1$ ) afforded the title product as a pale yellow oil (2.68 $\mathrm{g}, 88 \%) . \mathbf{R}_{\mathbf{f}}=0.23($ hexanes/EtOAc $=1: 1) ;{ }^{1} \mathbf{H} \mathbf{~ N M R}$ $\left(400 \mathrm{MHz}, \mathrm{CDCl}_{3}\right): \delta 7.32(\mathrm{~d}, J=7.6 \mathrm{~Hz}, 2 \mathrm{H}), 7.27(\mathrm{t}, J=7.2 \mathrm{~Hz}, 2 \mathrm{H}), 7.17(\mathrm{t}, J=7.2$ $\mathrm{Hz}, 1 \mathrm{H}), 6.42(\mathrm{~d}, J=16.0 \mathrm{~Hz}, 1 \mathrm{H}), 6.26(\mathrm{dt}, J=15.6,6.8 \mathrm{~Hz}, 1 \mathrm{H}), 2.98(\mathrm{~s}, 3 \mathrm{H}), 2.94(\mathrm{~s}$, $3 \mathrm{H}), 2.56-2.51(\mathrm{~m}, 2 \mathrm{H}), 2.47-2.43(\mathrm{t}, J=7.6 \mathrm{~Hz}, 2 \mathrm{H}) ;{ }^{13} \mathbf{C} \mathbf{N M R}\left(100 \mathrm{MHz}, \mathrm{CDCl}_{3}\right): \delta$ $172.2,137.6,130.6,129.6,128.5,127.0,126.0,37.2,35.4,33.1,28.6$; IR $\left(\mathrm{cm}^{-1}\right): 2930$, 1637, 1492, 1395, 1264, 1139, 964, 744, 692; ESI-HRMS (m/z): $[\mathrm{M}+\mathrm{H}]^{+}$calc'd for $\mathrm{C}_{13} \mathrm{H}_{18} \mathrm{NO}$ : 204.1383; found: 204.1382.

\section{1-Benzylazocan-2-one 1p}

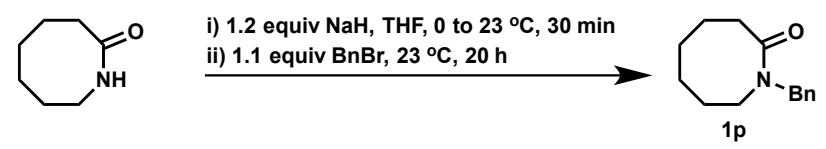


To $0{ }^{\circ} \mathrm{C}$ suspension of $\mathrm{NaH}(0.38 \mathrm{~g}, 9.6 \mathrm{mmol}, 1.2$ equiv, $60 \%$ dispersion in minera oil) in THF $(50 \mathrm{~mL}, 0.2 \mathrm{M})$ was added azocan-2-one $(1.0 \mathrm{~g}$ in $10 \mathrm{~mL}$ THF, 8.0 mmol. 1.0 equiv). After stirring for $10 \mathrm{~min}$ at $0{ }^{\circ} \mathrm{C}$, the cooling bath was removed and the reaction mixture was stirred for another $30 \mathrm{~min}$, then benzyl bromide $(1.0 \mathrm{~mL}, 8.8 \mathrm{mmol}$, 1.1 equiv) was added. The resulting mixture was stirred for $20 \mathrm{~h}$ at $23{ }^{\circ} \mathrm{C}$, and was stopped by addition of sat. aq. $\mathrm{NH}_{4} \mathrm{Cl}(20 \mathrm{~mL})$. The organic phase was separated. The aqueous phase was extracted with EtOAc $(3 \times 20 \mathrm{~mL})$ and the combined organic layers were washed with brine $(30 \mathrm{~mL})$, dried over anhydrous $\mathrm{Na}_{2} \mathrm{SO}_{4}$, filtered and concentrated under reduced pressure by rotary evaporation. Purification by flash column chromatography on silica gel (hexanes/EtOAc $=1: 1$ ) afforded the title product as a white solid (1.56 g, 90\%). M.P. $=43-44{ }^{\circ} \mathrm{C} ; \mathbf{R}_{\mathbf{f}}=0.37$ (hexanes/EtOAc $\left.=1: 1\right) ;{ }^{1} \mathbf{H}$ NMR (400 $\left.\mathrm{MHz}, \mathrm{CDCl}_{3}\right): \delta 7.32-7.22(\mathrm{~m}, 5 \mathrm{H}), 4.57(\mathrm{~s}, 2 \mathrm{H}), 3.39(\mathrm{t}, J=6.0 \mathrm{~Hz}, 2 \mathrm{H}), 2.56(\mathrm{t}, J=6.4$ $\mathrm{Hz}, 2 \mathrm{H}), 1.87-1.81(\mathrm{~m}, 2 \mathrm{H}), 1.59-1.52(\mathrm{~m}, 4 \mathrm{H}), 1.49-1.43(\mathrm{~m}, 2 \mathrm{H}) ;{ }^{13} \mathbf{C}$ NMR (100

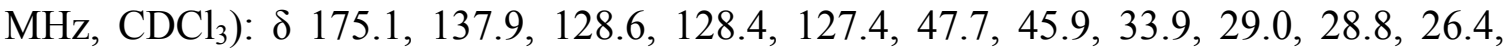
24.5; IR $\left(\mathrm{cm}^{-1}\right):$ 2930, 2853, 1620, 1483, 1451, 1355, 1134, 897, 735; ESI-HRMS (m/z): $[\mathrm{M}+\mathrm{H}]^{+}$calc'd for $\mathrm{C}_{14} \mathrm{H}_{20} \mathrm{NO}$ : 218.1539; found: 218.1521 .

\section{7-Methoxy-1-methyl-3,4-dihydroquinolin-2(1H)-one $1 \mathrm{~s}$}

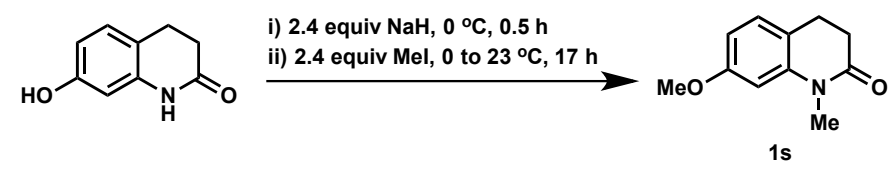

To $0{ }^{\circ} \mathrm{C}$ suspension of $\mathrm{NaH}(0.96 \mathrm{~g}, 24 \mathrm{mmol}, 2.4$ equiv, $60 \%$ dispersion in mineral oil) in THF (30 mL, $0.8 \mathrm{M})$ was added a 7-hydroxy-3,4-dihydroquinolin-2(1H)one (1.63 g, 1.0 equiv). After stirring for $10 \mathrm{~min}$ at $30{ }^{\circ} \mathrm{C}$, methyl iodide $(1.5 \mathrm{~mL}, 24$ mmol, 2.4 equiv) was added. Then the ice bath was removed and the resulting mixture was stirred for $17 \mathrm{~h}$ at $23{ }^{\circ} \mathrm{C}$, and was stopped by addition of sat. aq. $\mathrm{NH}_{4} \mathrm{Cl}(50 \mathrm{~mL})$, the organic phase was separated. The aqueous phase was extracted with EtOAc $(3 \times 30 \mathrm{~mL})$ and the combined organic layers were washed with brine $(50 \mathrm{~mL})$, dried over anhydrous $\mathrm{Na}_{2} \mathrm{SO}_{4}$, filtered and concentrated under reduced pressure by rotary evaporation. Purification by flash column chromatography on silica gel (hexanes/EtOAc $=1: 1$ ) afforded the title product as a white solid (578 $\mathrm{mg}, 30 \%$ ). M.P. $=76-78{ }^{\circ} \mathrm{C} ; \mathbf{R}_{\mathbf{f}}=0.23$ 
(hexanes/EtOAc $=2: 1) ;{ }^{1} \mathbf{H}$ NMR $\left(500 \mathrm{MHz}, \mathrm{CDCl}_{3}\right): \delta 7.06(\mathrm{t}, J=8.0 \mathrm{~Hz}, 1 \mathrm{H}), 6.54-$ $6.52(\mathrm{~m}, 2 \mathrm{H}), 3.81(\mathrm{~s}, 3 \mathrm{H}), 3.33(\mathrm{~s}, 3 \mathrm{H}), 2.83(\mathrm{t}, J=8.0 \mathrm{~Hz}, 2 \mathrm{H}), 2.62(\mathrm{t}, J=7.6 \mathrm{~Hz}, 2 \mathrm{H})$; ${ }^{13}$ C NMR (125 MHz, $\left.\mathrm{CDCl}_{3}\right): \delta 170.8,159.3,141.8,128.3,118.6,106.6,102.3,55.6$, 32.2, 29.8, 24.7; IR ( $\left.\mathrm{cm}^{-1}\right): 2921,1663,1590,1352,1125,829,694$; ESI-HRMS (m/z): $[\mathrm{M}+\mathrm{H}]^{+}$calc'd for $\mathrm{C}_{11} \mathrm{H}_{14} \mathrm{NO}_{2}:$ 192.1019; found: 192.1002. The spectral data are consistent with those reported in the literature. ${ }^{11}$

\section{Amide 1v}

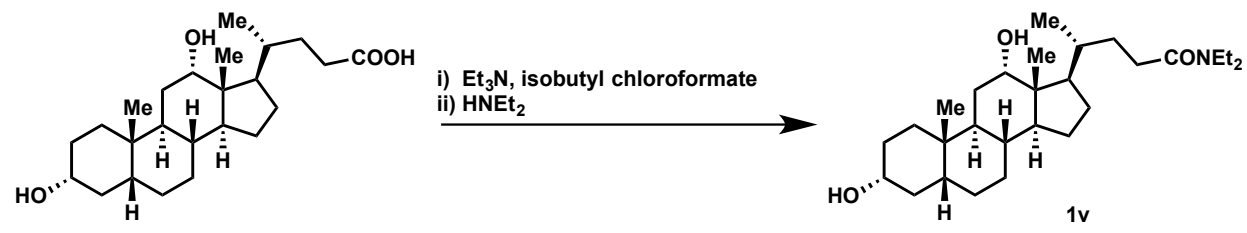

To a $0{ }^{\circ} \mathrm{C}$ solution of deoxycholic acid $\left(3.92 \mathrm{~g}, 10 \mathrm{mmol}, 1.0\right.$ equiv) and $\mathrm{Et}_{3} \mathrm{~N}(2.0$ $\mathrm{mL}, 14 \mathrm{mmol}, 1.4$ equiv) in THF $(200 \mathrm{~mL})$ was added isobutyl chloroformate $(2.0 \mathrm{~mL}$, $15 \mathrm{mmol}, 1.5$ equiv). The mixture was stirred at $0{ }^{\circ} \mathrm{C}$ for $10 \mathrm{~min}$, and then diethylamine $\left(20 \mathrm{~mL}\right.$ ) was added at the same temperature. The resulting mixture was stirred at $23{ }^{\circ} \mathrm{C}$ for $12 \mathrm{~h}$, and then diluted with EtOAc $(100 \mathrm{~mL})$. The organic layer was washed with sat. aq. $\mathrm{NH}_{4} \mathrm{Cl}(150 \mathrm{~mL})$ and brine $(150 \mathrm{~mL})$, dried over anhydrous $\mathrm{Na}_{2} \mathrm{SO}_{4}$, filtered and concentrated under reduced pressure by rotary evaporation. Purification by flash column chromatography on silica gel (EtOAc/ $\mathrm{MeOH}=1: 0$ to 20:1) afforded the title product as a white solid (3.32, 74\%). M.P. $=175-177{ }^{\circ} \mathrm{C} ; \mathbf{R}_{\mathbf{f}}=0.21\left(\right.$ EtOAc); $[\alpha]_{\mathrm{D}}^{23}+43.6(c, 1.16$, $\mathrm{CHCl}_{3}$ ); ${ }^{1} \mathbf{H}$ NMR (400 MHz, $\left.\mathrm{CDCl}_{3}\right): \delta 3.98$ (bs, $\left.1 \mathrm{H}\right), 3.62$ (bs, 1H), 3.44-3.27 (m, 4H), 2.39-2.32 (m, 1H), 2.24-2.16 (m, 1H), 1.91-1.24 (m, 24H), 1.24-1.08 (m, 7H), 1.010.99 (m, 4H), 0.91 (s, 3H), 0.68 (s, 3H); ${ }^{13} \mathbf{C}$ NMR (100 MHz, $\left.\mathrm{CDCl}_{3}\right): \delta$ 172.7, 73.2, 71.8, 48.3, 47.3, 46.5, 42.1, 42.0, 40.0 36.4, 36.0, 35.3, 35.2, 34.1, 33.6, 31.4, 30.5, 29.9, 28.6, 27.5, 27.1, 26.1, 23.6, 23.1, 17.6, 14.4, 13.1, 12.8; IR $\left(\mathrm{cm}^{-1}\right): 3384,2978,2926$, 2861, 1612, 1459, 1306, 1280, 1097, 1044, 797; ESI-HRMS (m/z): $[\mathrm{M}+\mathrm{H}]^{+}$calc'd for $\mathrm{C}_{28} \mathrm{H}_{50} \mathrm{NO}_{3}$ : 448.3785; found: 448.3757 .

\section{7-Hydroxy-1-methyl-3,4-dihydroquinolin-2(1H)-one $1 y$}
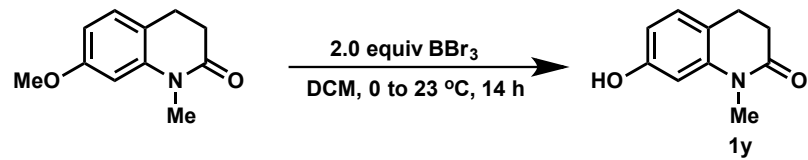
To a $0{ }^{\circ} \mathrm{C}$ solution of $1 \mathrm{~s}(0.33 \mathrm{~g}, 2.0 \mathrm{mmol}, 1.0$ equiv) in DCM (10 mL, $0.2 \mathrm{M})$ was dropwise added $\mathrm{BBr}_{3}(0.40 \mathrm{~mL}, 2.0$ equiv). Then the resulting mixture was slowly warmed up to $23{ }^{\circ} \mathrm{C}$, and stirred for $14 \mathrm{~h}$. The reaction mixture was concentrated under reduced pressure by rotary evaporation. Purification by flash column chromatography on silica gel $($ EtOAc/DCM/hexanes $=1: 1: 1)$ afforded the title product as a yellow solid $(0.29$ g, 83\%). M.P. $=165-169{ }^{\circ} \mathrm{C} ; \mathbf{R}_{\mathbf{f}}=0.30$ (hexanes/EtOAc $\left.=1: 1\right) ;{ }^{1} \mathbf{H}$ NMR $(400 \mathrm{MHz}$, DMSO-d $\left._{6}\right): \delta 9.38(\mathrm{~s}, 1 \mathrm{H}), 6.96(\mathrm{~d}, J=8.4 \mathrm{~Hz}, 1 \mathrm{H}), 6.47(\mathrm{~s}, 1 \mathrm{H}), 6.38(\mathrm{~d}, J=10.0 \mathrm{~Hz}$, 1H), $3.17(\mathrm{~s}, 3 \mathrm{H}), 2.71(\mathrm{t}, J=7.6 \mathrm{~Hz}, 2 \mathrm{H}), 2.47$ (t, $J=7.6 \mathrm{~Hz}, 2 \mathrm{H}) ;{ }^{13} \mathbf{C}$ NMR (100 MHz, DMSO-d $\left.{ }_{6}\right): \delta 169.5,156.7,141.2,128.1,116.1,108.7,102.6,31.7,28.9,23.8 ;$ IR $\left(\mathrm{cm}^{-1}\right)$ : 3141, 1645, 1594, 1518, 1467, 1324, 1126, 1062, 769; ESI-HRMS (m/z): [M+H] $]^{+}$calc'd for $\mathrm{C}_{10} \mathrm{H}_{12} \mathrm{NO}_{2}$ : 178.0863; found: 178.0876 .

\section{$\mathrm{N}, \mathrm{N}$-dibenzyl-3-(1H-indol-3-yl)propanamide $1 \mathrm{z}$}

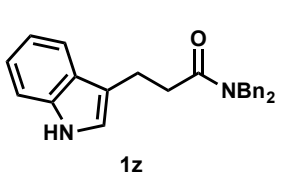

General procedure B was followed with a reaction time of 24 hours.

Purification by flash column chromatography on silica gel (hexanes/EtOAc $=3: 1$ to $2: 1$ ) afforded the title product as a yellow oil in $81 \%$ yield (2.98 g). $\mathbf{R}_{\mathbf{f}}=0.30$ (hexanes/EtOAc $\left.=2: 1\right) ;{ }^{1} \mathbf{H} \mathbf{N M R}\left(400 \mathrm{MHz}, \mathrm{CDCl}_{3}\right): \delta$ $8.00(\mathrm{~s}, 1 \mathrm{H}), 7.50$ (d, $J=8.0 \mathrm{~Hz}, 1 \mathrm{H}), 7.34$ (d, $J=8.0 \mathrm{~Hz}, 1 \mathrm{H}), 7.32-7.24$ (m, 6H), 7.19$7.15(\mathrm{~m}, 3 \mathrm{H}), 7.07$ (d, $J=8.0 \mathrm{~Hz}, 1 \mathrm{H}), 7.06(\mathrm{~d}, J=6.8 \mathrm{~Hz}, 3 \mathrm{H}), 6.98$ (d, $J=2.4 \mathrm{~Hz}, 1 \mathrm{H})$, $4.62(\mathrm{~s}, 2 \mathrm{H}), 4.36(\mathrm{~s}, 2 \mathrm{H}), 3.21(\mathrm{t}, J=8.0 \mathrm{~Hz}, 2 \mathrm{H}), 2.82(\mathrm{t}, J=8.0 \mathrm{~Hz}, 2 \mathrm{H}) ;{ }^{13} \mathbf{C}$ NMR $\left(100 \mathrm{MHz}, \mathrm{CDCl}_{3}\right): \delta 173.5,137.5,136.6,136.4,129.0,128.7,128.4,127.7,127.5$, 127.3, 126.4, 122.1, 121.9, 119.4, 118.8, 115.4, 111.2, 50.0, 48.5, 34.1, 21.3; IR (cm $\left.{ }^{-1}\right)$ : 3312, 3062, 1914, 1626, 1494, 1418, 1209, 1028, 957, 728; ESI-HRMS (m/z): [M+H] ${ }^{+}$ calc'd for $\mathrm{C}_{25} \mathrm{H}_{25} \mathrm{~N}_{2} \mathrm{O}$ : 369.1961 ; found: 369.1962 .

\section{4-(1H-indol-3-yl)-1-morpholinobutan-1-one 1aa}

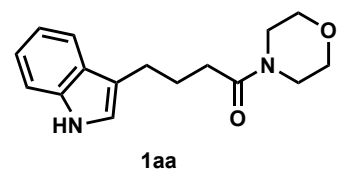

General procedure $B$ was followed with a reaction time of 48 hours. Purification by flash column chromatography on silica gel (hexanes/EtOAc $=1: 1$ to $0: 1$ ) afforded the title product as a white solid in 59\% yield (806 mg). M.P. $=130-131{ }^{\circ} \mathrm{C} ; \mathbf{R}_{\mathbf{f}}=0.55$ (EtOAc); ${ }^{1} \mathbf{H}$ NMR (400 $\left.\mathrm{MHz}_{\mathrm{CDCl}}\right): \delta 8.17(\mathrm{~s}, 1 \mathrm{H}), 7.60(\mathrm{~d}, J=8.0 \mathrm{~Hz}, 1 \mathrm{H}), 7.35(\mathrm{~d}, J=8.0 \mathrm{~Hz}, 1 \mathrm{H}), 7.18(\mathrm{td}$, $J=8.0,0.8 \mathrm{~Hz}, 1 \mathrm{H}), 7.11(\mathrm{td}, J=8.0,0.8 \mathrm{~Hz}, 1 \mathrm{H}), 6.99$ (d, $J=2.0 \mathrm{~Hz}, 1 \mathrm{H}), 3.64-3.55$ 
(m, 6H), 3.33 (t, $J=4.4 \mathrm{~Hz}, 2 \mathrm{H}), 2.84(\mathrm{t}, J=7.2 \mathrm{~Hz}, 2 \mathrm{H}), 2.37$ (t, $J=7.6 \mathrm{~Hz}, 2 \mathrm{H}), 2.08$ (quint, $J=7.6 \mathrm{~Hz}, 2 \mathrm{H}) ;{ }^{13} \mathbf{C}$ NMR $\left(100 \mathrm{MHz}, \mathrm{CDCl}_{3}\right): \delta 171.9,136.5,127.6,122.0$, $121.6,119.3,119.0,115.7,111.3,67.0,66.7,46.0,42.0,32.6,25.6,24.7 ;$ IR $\left(\mathrm{cm}^{-1}\right)$ : 3207, 2948, 1622, 1446, 1409, 1271, 1109, 792; ESI-HRMS (m/z): [M+H $]^{+}$calc'd for $\mathrm{C}_{16} \mathrm{H}_{21} \mathrm{~N}_{2} \mathrm{O}_{2}$ : 273.1598; found: 273.1595 .

\section{Lactam 1ab}

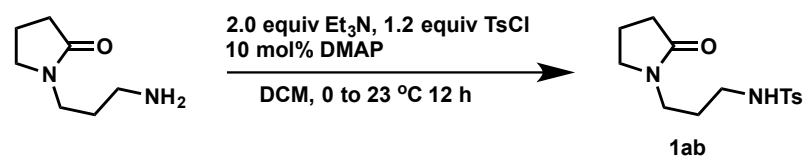

To a $0{ }^{\circ} \mathrm{C}$ solution of 1-(3-aminopropyl)pyrrolidin-2-one $(0.70 \mathrm{~mL}, 5.0 \mathrm{mmol}, 1.0$ equiv) in DCM (10 mL, $0.5 \mathrm{M})$ was added $\mathrm{Et}_{3} \mathrm{~N}$ (1.4 mL, $10 \mathrm{mmol}, 2.0$ equiv), DMAP (61 mg, $0.5 \mathrm{mmol}, 0.5$ equiv) and $\mathrm{TsCl}(1.15 \mathrm{~g}, 2.0$ equiv, $6.0 \mathrm{mmol})$. Then the resulting mixture was slowly warmed up to $23{ }^{\circ} \mathrm{C}$, stirred for $12 \mathrm{~h}$ and stopped with the addition of water $(30 \mathrm{~mL})$, and the organic phase was separated. The aqueous phase was extracted with DCM $(3 \times 20 \mathrm{~mL})$ and the combined organic layers were washed with brine $(50$ $\mathrm{mL}$ ), dried over anhydrous $\mathrm{Na}_{2} \mathrm{SO}_{4}$, filtered, and concentrated under reduced pressure by rotary evaporation. Purification by flash column chromatography on silica gel (EtOAc) afforded the title product as a white solid (1.15 g, 78\%). M.P. $=126-127{ }^{\circ} \mathrm{C} ; \mathbf{R}_{\mathbf{f}}=0.19$ (EtOAc); ${ }^{1} \mathbf{H}$ NMR $\left(400 \mathrm{MHz}, \mathrm{CDCl}_{3}\right): \delta 7.73(\mathrm{~d}, J=8.0 \mathrm{~Hz}, 2 \mathrm{H}), 7.27(\mathrm{~d}, J=8.0 \mathrm{~Hz}$, 2H), $5.91(\mathrm{t}, J=6.4 \mathrm{~Hz}, 1 \mathrm{H}), 3.31$ (t, $J=7.2 \mathrm{~Hz}, 4 \mathrm{H}), 2.84$ (q, $J=6.4 \mathrm{~Hz}, 2 \mathrm{H}), 2.39$ (s, $3 \mathrm{H}$ ), 2.32 (t, $J=7.6 \mathrm{~Hz}, 2 \mathrm{H}$ ), 1.98 (quint, $J=7.6 \mathrm{~Hz}, 2 \mathrm{H}$ ), 1.67 (quint, $J=6.4 \mathrm{~Hz}, 2 \mathrm{H}$ ); ${ }^{13}$ C NMR $\left(100 \mathrm{MHz}, \mathrm{CDCl}_{3}\right): \delta 176.1,143.1,137.5,129.7,127.2,47.5,39.8,39.4,30.8$, 27.1, 21.6, 18.0; IR $\left(\mathrm{cm}^{-1}\right): 3135,2867,1659,1453,1158,1121,1093$, 824, 661; ESIHRMS (m/z): $[\mathrm{M}+\mathrm{H}]^{+}$calc'd for $\mathrm{C}_{14} \mathrm{H}_{21} \mathrm{~N}_{2} \mathrm{O}_{3} \mathrm{~S}$ : 297.1267; found: 297.1281.

\section{$N, N$-dibenzyl-3-(4-pivalamidophenyl)propanamide 1 ac}

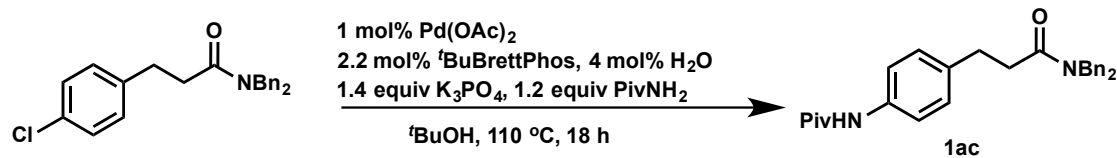

The reaction was performed via Buchwald amidation procedure: ${ }^{12}$ An oven-dried test tube, which was equipped with a magnetic stir bar was charged with $\mathrm{Pd}(\mathrm{OAc})_{2}(2.2$ mg, $0.01 \mathrm{mmol}, 0.01$ equiv) and ${ }^{t} \mathrm{BuBrettPhos}$ (11 mg, $0.022 \mathrm{mmol}, 0.022$ equiv). The 
vessel was evacuated and backfilled with argon (this process was repeated a total of three times) and ${ }^{t} \mathrm{BuOH}(2.0 \mathrm{~mL})$ and degassed $\mathrm{H}_{2} \mathrm{O}(1 \mu \mathrm{L}, 0.04 \mathrm{mmol}, 0.04 \mathrm{mmol})$ were added via syringe. After addition of the water, the solution was heated to $110^{\circ} \mathrm{C}$ for $1.5 \mathrm{~min}$. A second sealed tube, equipped with a magnetic stir bar, was charged with $\mathrm{PivNH}_{2}(121$ mg, 1.2 mmol, 1.2 equiv), $\mathrm{K}_{3} \mathrm{PO}_{4}(297 \mathrm{mg}, 1.4 \mathrm{mmol}, 1.4$ equiv) and aryl chloride $1 \mathbf{i}$ (364 $\mathrm{mg}, 1.0 \mathrm{mmol}, 1.0$ equiv). The vessel was evacuated and backfilled with argon (this process was repeated a total of three times) and the activated catalyst solution was transferred from the first reaction vessel into the second via cannula. The solution was heated to $110{ }^{\circ} \mathrm{C}$ and stirred for $18 \mathrm{~h}$. The reaction mixture was then cooled to room temperature, diluted with EtOAc $(20 \mathrm{~mL})$, and washed with water. The layers were separated and the organic layer was dried over anhydrous $\mathrm{Na}_{2} \mathrm{SO}_{4}$, filtered, and concentrated in vacuo. The crude product was purified via flash chromatography on silica gel (hexanes/EtOAc $=2: 1)$ to afford the title product as a white solid $(327 \mathrm{mg}, 76 \%$ ). M.P. $=99-103{ }^{\circ} \mathrm{C} ; \mathbf{R}_{\mathbf{f}}=0.23$ (hexanes/EtOAc $\left.=2: 1\right) ;{ }^{1} \mathbf{H}$ NMR $\left(600 \mathrm{MHz}, \mathrm{CDCl}_{3}\right): \delta$ $7.41(\mathrm{~d}, J=8.4 \mathrm{~Hz}, 2 \mathrm{H}), 7.34-7.25(\mathrm{~m}, 7 \mathrm{H}), 7.17(\mathrm{~d}, J=7.2 \mathrm{~Hz}, 2 \mathrm{H}), 7.11(\mathrm{~d}, J=7.8 \mathrm{~Hz}$, 2H), 7.07 (d, $J=7.2 \mathrm{~Hz}, 2 \mathrm{H}$ ), 4.59 (s, 2H), 4.38 (s, 2H), 3.00 (t, $J=7.8 \mathrm{~Hz}, 2 \mathrm{H}), 2.68$ (t, $J=7.8 \mathrm{~Hz}, 2 \mathrm{H}), 1.30(\mathrm{~S}, 9 \mathrm{H}) ;{ }^{13} \mathbf{C}$ NMR $\left(150 \mathrm{MHz}, \mathrm{CDCl}_{3}\right): \delta 176.6,172.8,137.4$, 137.2, 136.5, 136.3, 129.1, 128.7, 128.4, 127.7, 127.5, 126.4, 120.2, 50.1, 48.5, 39.7, 35.2, 31.1, 27.8; IR $\left(\mathrm{cm}^{-1}\right): 3353,1652,1635,1494,1448,1224,1160,930,832$; ESIHRMS (m/z): $[\mathrm{M}+\mathrm{H}]^{+}$calc'd for $\mathrm{C}_{28} \mathrm{H}_{33} \mathrm{~N}_{2} \mathrm{O}_{2}$ : 429.2537; found: 429.2548 .

\section{Amide 1ad}

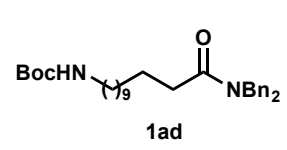

General procedure B was followed with a reaction time of 24 hours from 12-((tert-butoxycarbonyl)amino)dodecanoic acid. ${ }^{13}$ Purification by flash column chromatography on silica gel $\left(\mathrm{CH}_{2} \mathrm{Cl}_{2} / \mathrm{EtOAc}=1: 0\right.$ to 10:1) afforded the title product as a viscous colorless oil in 59\% yield (2.20 g). $\mathbf{R}_{\mathbf{f}}=0.21$ (hexanes/EtOAc = 4:1); ${ }^{1} \mathbf{H}$ NMR $\left(400 \mathrm{MHz}, \mathrm{CDCl}_{3}\right): \delta 7.36-7.24$ (m, 6H), 7.19 (d, $J=$ $7.2 \mathrm{~Hz}, 2 \mathrm{H}$ ), 7.13 (d, $J=7.6 \mathrm{~Hz}, 2 \mathrm{H}), 4.58$ (bs, 3H), 4.43 (s, 2H), 3.07 (q, $J=6.4 \mathrm{~Hz}$, 2H), 2.40 (t, $J=7.6 \mathrm{~Hz}, 2 \mathrm{H}), 1.69$ (t, $J=7.6 \mathrm{~Hz}, 2 \mathrm{H}), 1.42$ (s, 11H), 1.34-1.17 (m, 14H); ${ }^{13} \mathrm{C}$ NMR $\left(100 \mathrm{MHz}, \mathrm{CDCl}_{3}\right): \delta 173.8,156.1,137.6,136.7,129.0,128.6,128.3,127.6$, $127.4,126.4,79.0,50.0,48.1,40.7,33.3,30.1,29.6,29.6,29.5,29.5,29.3,28.5,26.9$, 
25.5; IR $\left(\mathrm{cm}^{-1}\right): 3450,2926,2853,1709,1636,1495,1452,1364,1169,1080,729,698$;

ESI-HRMS (m/z): [M-C $\left.{ }_{5} \mathrm{H}_{7} \mathrm{O}_{2}\right]^{+}$calc'd for $\mathrm{C}_{26} \mathrm{H}_{39} \mathrm{~N}_{2} \mathrm{O}$ : 395.3057; found: 395.3079 .

\section{3-phenyl-1-(piperazin-1-yl)propan-1-one 1ae}

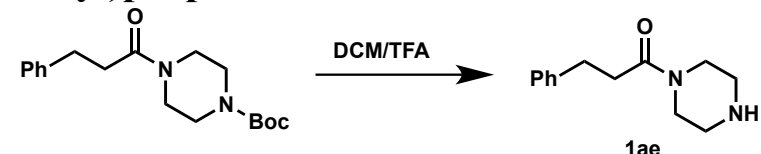

To a $0{ }^{\circ} \mathrm{C}$ solution of $\mathbf{1 d}(636 \mathrm{mg}, 2.0 \mathrm{mmol}, 1.0$ equiv) in DCM (20 mL, $0.1 \mathrm{M})$ was added TFA ( $5 \mathrm{~mL})$. The reaction was slowly warmed up to $23{ }^{\circ} \mathrm{C}$, stirred for $12 \mathrm{~h} .10$ $\mathrm{mL}$ of toluene was added, and the reaction mixture was concentrated under reduced pressure. This process was repeated with an additional $10 \mathrm{~mL}$ toluene. Purification by flash column chromatography on silica gel $(\mathrm{DCM} / \mathrm{MeOH}=10: 1)$ afforded the title product as a colorless oil $(221 \mathrm{mg}, 50 \%) . \mathbf{R}_{\mathbf{f}}=0.19$ (EtOAc); ${ }^{1} \mathbf{H}$ NMR (400 MHz, $\left.\mathrm{CDCl}_{3}\right): \delta 7.27(\mathrm{t}, J=7.6 \mathrm{~Hz}, 2 \mathrm{H}), 7.21-7.17(\mathrm{~m}, 3 \mathrm{H}), 3.60(\mathrm{t}, J=4.8 \mathrm{~Hz}, 2 \mathrm{H}), 3.36(\mathrm{t}, J$ $=4.8 \mathrm{~Hz}, 2 \mathrm{H}), 2.95(\mathrm{t}, J=7.2 \mathrm{~Hz}, 2 \mathrm{H}), 2.80(\mathrm{~s}, 3 \mathrm{H}), 2.72(\mathrm{t}, J=4.8 \mathrm{~Hz}, 2 \mathrm{H}), 2.60(\mathrm{t}, J=$ $7.6 \mathrm{~Hz}, 2 \mathrm{H}) ;{ }^{13} \mathbf{C}$ NMR $\left(100 \mathrm{MHz}, \mathrm{CDCl}_{3}\right): \delta 170.8,141.2,128.6,128.5,126.3,46.4$, 46.0, 45.7, 42.4, 35.0, 31.6; IR ( $\left.\mathrm{cm}^{-1}\right): 3463,2932,1620,1497,1439,1265,1136,1117$, 749; ESI-HRMS (m/z): [M+H] $]^{+}$calc'd for $\mathrm{C}_{13} \mathrm{H}_{19} \mathrm{~N}_{2} \mathrm{O}$ : 219.1492; found: 219.1501 .

\section{Amide 1f}

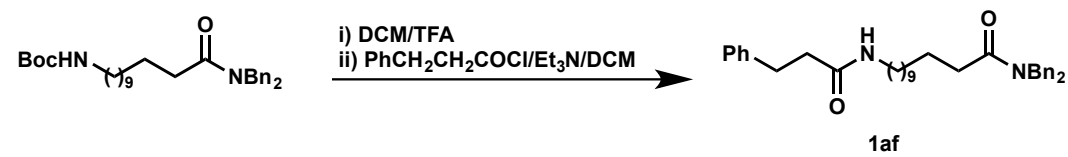

To a $0{ }^{\circ} \mathrm{C}$ solution of $\mathbf{1 a d}(742 \mathrm{mg}, 1.5 \mathrm{mmol}, 1.0$ equiv) in DCM (8 mL, $0.19 \mathrm{M})$ was added TFA $(2 \mathrm{~mL})$. The reaction was warmed up to $23{ }^{\circ} \mathrm{C}$, stirred for $2 \mathrm{~h} .10 \mathrm{~mL}$ of toluene was added, and the reaction mixture was concentrated under reduced pressure. This process was repeated with an additional $10 \mathrm{~mL}$ toluene. To a $0{ }^{\circ} \mathrm{C}$ solution of acid intermediate in $\mathrm{CH}_{2} \mathrm{Cl}_{2}(10 \mathrm{~mL}, 0.13 \mathrm{M})$ was added anhydrous $\mathrm{Et}_{3} \mathrm{~N}(2.1 \mathrm{~mL}, 15 \mathrm{mmol}$, 10 equiv). After stirring for $5 \mathrm{~min}$ at $0{ }^{\circ} \mathrm{C}$, hydrocinnamoyl chloride $(0.22 \mathrm{~mL}, 1.5 \mathrm{mmol}$, 1.0 equiv) was dropwise added into the mixture. Then the resulting mixture was slowly warmed up to $23{ }^{\circ} \mathrm{C}$, stirred for $12 \mathrm{~h}$ and stopped with the addition of water $(20 \mathrm{~mL})$, and the organic phase was separated. The aqueous phase was extracted with DCM $(3 \times 10$ $\mathrm{mL})$ and the combined organic layers were washed with brine $(30 \mathrm{~mL})$, dried over 
anhydrous $\mathrm{Na}_{2} \mathrm{SO}_{4}$, filtered, and concentrated under reduced pressure by rotary evaporation. Purification by flash column chromatography on silica gel (hexanes/EtOAc $=1: 1)$ afforded the title product as a colorless solid ( $702 \mathrm{mg}, 89 \%$ for two steps). M.P. $=$ $60-62{ }^{\circ} \mathrm{C} ; \mathbf{R}_{\mathbf{f}}=0.30$ (hexanes/EtOAc $\left.=1: 1\right) ;{ }^{1} \mathbf{H}$ NMR $\left(500 \mathrm{MHz}, \mathrm{CDCl}_{3}\right): \delta 7.37(\mathrm{t}, J=$ $7.5 \mathrm{~Hz}, 2 \mathrm{H}), 7.32-7.19$ (m, 11H), 7.15 (d, $J=7.5 \mathrm{~Hz}, 2 \mathrm{H}), 5.33$ (bs, 1H), 4.60 (s, 2H), 4.45 (s, 2H), 3.19 (q, $J=6.5 \mathrm{~Hz}, 2 \mathrm{H}), 2.96$ (t, $J=7.5 \mathrm{~Hz}, 2 \mathrm{H}), 2.45$ (q, $J=7.5 \mathrm{~Hz}, 2 \mathrm{H})$, 2.41 (t, $J=7.5 \mathrm{~Hz}, 2 \mathrm{H}$ ), 1.71 (quint, $J=7.5 \mathrm{~Hz}, 2 \mathrm{H}$ ), 1.40 (quint, $J=7.0 \mathrm{~Hz}, 2 \mathrm{H}$ ), 1.31 $1.20(\mathrm{~m}, 14 \mathrm{H}) ;{ }^{13} \mathbf{C}$ NMR $\left(125 \mathrm{MHz}, \mathrm{CDCl}_{3}\right): \delta 173.9,172.1,141.1,137.7,136.8,129.1$, 128.7, 128.6, 128.5, 128.4, 127.7, 127.5, 126.5, 126.3, 50.1, 48.2, 39.7, 38.7, 33.4, 32.0, 30.0, 29.6, 29.6, 29.6, 29.5, 29.4, 27.0, 25.6; IR $\left(\mathrm{cm}^{-1}\right): 3325,2923,2852,1639,1542$, 1469, 1208, 1076, 749, 735; ESI-HRMS $(\mathrm{m} / \mathrm{z}):[\mathrm{M}+\mathrm{H}]^{+}$calc'd for $\mathrm{C}_{35} \mathrm{H}_{47} \mathrm{~N}_{2} \mathrm{O}_{2}$ : 527.3632; found: 527.3638 .

\section{Amide 1ag}

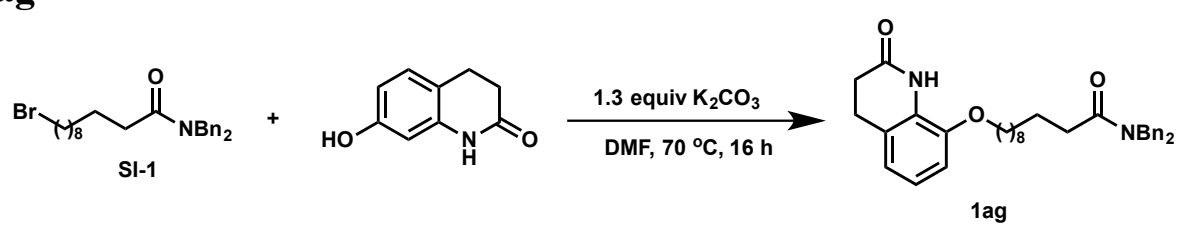

Amide SI-1 was prepared according to the general procedure B with a reaction time of 48 hours. Purification by flash column chromatography on silica gel (hexanes/ $\mathrm{Et}_{2} \mathrm{O}=7: 1$ to $4: 1$ ) afforded the title product as a viscous yellow oil in $73 \%$ yield (13.1 g). $\mathbf{R}_{\mathbf{f}}=0.37$ (hexanes/EtOAc = 3:1); ${ }^{1} \mathbf{H}$ NMR (400 MHz, $\left.\mathrm{CDCl}_{3}\right): \delta 7.39-7.25(\mathrm{~m}$, $6 \mathrm{H}), 7.21$ (d, $J=6.8 \mathrm{~Hz}, 2 \mathrm{H}), 7.15$ (d, $J=7.2 \mathrm{~Hz}, 2 \mathrm{H}), 4.60$ (s, 2H), 4.45 (s, 2H), 3.40 (t, $J=6.8 \mathrm{~Hz}, 2 \mathrm{H}$ ), 2.41 (t, $J=7.6 \mathrm{~Hz}, 2 \mathrm{H}$ ), 1.84 (quint, $J=7.6 \mathrm{~Hz}, 2 \mathrm{H}$ ), 1.71 (quint, $J=6.8$ $\mathrm{Hz}, 2 \mathrm{H}), 1.41$ (quint, $J=7.2 \mathrm{~Hz}, 2 \mathrm{H}), 1.35-1.23(\mathrm{~m}, 10 \mathrm{H}) ;{ }^{13} \mathbf{C} \mathbf{N M R}\left(100 \mathrm{MHz}, \mathrm{CDCl}_{3}\right)$ : $\delta$ 173.9, 137.7, 136.8, 129.1, 128.7, 128.4, 127.7, 127.5, 126.5, 50.0, 48.2, 45.3, 34.2, 33.4, 33.0, 29.5, 29.5, 28.9, 28.3, 25.6; IR $\left(\mathrm{cm}^{-1}\right): 2925,3853,1646,1496,1452,1361$, 1208, 1078, 729; ESI-HRMS (m/z): $[\mathrm{M}+\mathrm{H}]^{+}$calc'd for $\mathrm{C}_{25} \mathrm{H}_{35}{ }^{79} \mathrm{BrNO}$ : 444.1902; found: 444.1883 .

To the solution of SI-1 (1.37 g, $3.0 \mathrm{mmol}, 1.0$ equiv) in DMF (15 mL, $0.2 \mathrm{M})$ was added 7-hydroxy-3,4-dihydroquinolin-2(1H)-one (538 mg, $3.3 \mathrm{mmol}, 1.1$ equiv) and $\mathrm{K}_{2} \mathrm{CO}_{3}\left(538 \mathrm{mg}, 3.9 \mathrm{mmol}, 1.3\right.$ equiv). The mixture was placed into a preheated $70{ }^{\circ} \mathrm{C}$ oil 
bath and stirred for $16 \mathrm{~h}$. The resulting mixture was cooled to room temperature and stopped by the addition of water $(50 \mathrm{~mL})$, diluted with EtOAc $(80 \mathrm{~mL})$, and the organic phase was separated. The aqueous phase was extracted with EtOAc $(3 \times 40 \mathrm{~mL})$ and the combined organic layers were washed with water $(100 \mathrm{~mL})$ and brine $(100 \mathrm{~mL})$, dried over anhydrous $\mathrm{Na}_{2} \mathrm{SO}_{4}$, filtered, and concentrated under reduced pressure by rotary evaporation. Purification by flash column chromatography on silica gel (hexanes/EtOAc $=3: 1$ to $1: 1)$ afforded amide $\mathbf{1 a g}$ as a yellow solid (1.13 g, $72 \%)$. M.P. $=105-107{ }^{\circ} \mathrm{C} ; \mathbf{R}_{\mathbf{f}}$ $=0.35$ (hexanes/EtOAc $=1: 1) ;{ }^{1} \mathbf{H}$ NMR $\left(400 \mathrm{MHz}, \mathrm{CDCl}_{3}\right): \delta 7.96(\mathrm{~s}, 1 \mathrm{H}), 7.36(\mathrm{t}, J=$ $7.6 \mathrm{~Hz}, 2 \mathrm{H}), 7.31-7.27(\mathrm{~m}, 4 \mathrm{H}), 7.20$ (d, $J=6.8 \mathrm{~Hz}, 2 \mathrm{H}), 7.14(\mathrm{~d}, J=7.2 \mathrm{~Hz}, 2 \mathrm{H}), 7.02$ $(\mathrm{d}, J=8.4 \mathrm{~Hz}, 1 \mathrm{H}), 6.51(\mathrm{t}, J=6.0 \mathrm{~Hz}, 1 \mathrm{H}), 6.32(\mathrm{~d}, J=2.4 \mathrm{~Hz}, 1 \mathrm{H}), 4.60(\mathrm{~s}, 2 \mathrm{H}), 4.44$ (s, 2H), $3.90(\mathrm{t}, J=6.8 \mathrm{~Hz}, 2 \mathrm{H}), 2.88(\mathrm{t}, J=8.0 \mathrm{~Hz}, 2 \mathrm{H}), 2.60(\mathrm{t}, J=7.2 \mathrm{~Hz}, 2 \mathrm{H}), 2.41(\mathrm{t}$, $J=7.6 \mathrm{~Hz}, 2 \mathrm{H}), 1.72$ (sept, $J=6.8 \mathrm{~Hz}, 4 \mathrm{H}), 1.44-1.38(\mathrm{~m}, 2 \mathrm{H}), 1.33-1.23(\mathrm{~m}, 10 \mathrm{H}) ;{ }^{13} \mathrm{C}$ NMR $\left(100 \mathrm{MHz}, \mathrm{CDCl}_{3}\right): \delta 173.9,171.7,158.9,138.2,137.7,136.8,129.1,128.8$, $128.7,128.4,127.7,127.5,126.5,115.7,108.7,102.3,68.3,50.0,48.2,33.4,31.3,29.5$, 29.5, 29.4, 29.4, 29.3, 26.1, 25.6, 24.7; IR ( $\left.\mathrm{cm}^{-1}\right): 2912,2848,1677,1640,1594,1522$, 1451, 1381, 1188, 1029, 848, 741; ESI-HRMS (m/z): $[\mathrm{M}+\mathrm{H}]^{+}$calc'd for $\mathrm{C}_{34} \mathrm{H}_{43} \mathrm{~N}_{2} \mathrm{O}_{3}$ : 527.3274; found: 527.3251 .

\section{Amide 1ah}
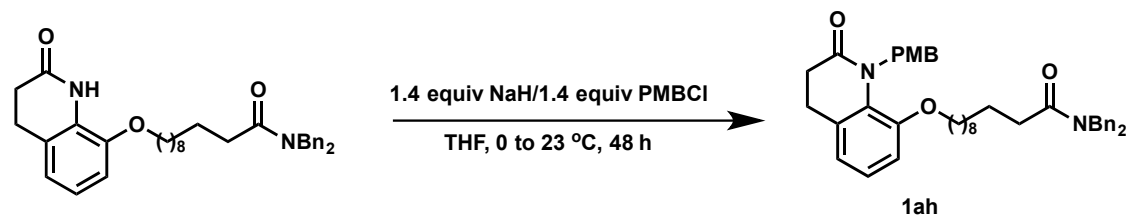

To $0{ }^{\circ} \mathrm{C}$ suspension of $\mathrm{NaH}(82 \mathrm{mg}, 2.1 \mathrm{mmol}, 1.4$ equiv, $60 \%$ dispersion in minera oil) in DMF (10 mL, $0.21 \mathrm{M})$ was added amide 1ag (790 mg, 1.0 equiv). After stirring for $10 \mathrm{~min}$ at $0{ }^{\circ} \mathrm{C}, \mathrm{PMBCl}(1.5 \mathrm{~mL}, 2.1 \mathrm{mmol}, 1.4$ equiv) was added. Then the ice bath was removed and the resulting mixture was stirred for $48 \mathrm{~h}$ at $23{ }^{\circ} \mathrm{C}$, and was stopped by addition of sat. aq. $\mathrm{NH}_{4} \mathrm{Cl}(30 \mathrm{~mL})$, the organic phase was separated. The aqueous phase was extracted with EtOAc $(3 \times 30 \mathrm{~mL})$ and the combined organic layers were washed with water $(50 \mathrm{~mL})$ and brine $(50 \mathrm{~mL})$, dried over anhydrous $\mathrm{Na}_{2} \mathrm{SO}_{4}$, filtered and concentrated under reduced pressure by rotary evaporation. Purification by 
flash column chromatography on silica gel (hexanes/EtOAc $=3: 1$ to $2: 1$ ) afforded the title product as a colorless viscous oil $(793 \mathrm{mg}, 82 \%)$. $\mathbf{R}_{\mathbf{f}}=0.29$ (hexanes/EtOAc $\left.=2: 1\right)$; ${ }^{1}$ H NMR $\left(500 \mathrm{MHz}, \mathrm{CDCl}_{3}\right): \delta 7.40-7.16(\mathrm{~m}, 12 \mathrm{H}), 7.03(\mathrm{~d}, J=7.6 \mathrm{~Hz}, 1 \mathrm{H}), 6.84(\mathrm{~d}, J=$ $8.0 \mathrm{~Hz}, 2 \mathrm{H}), 6.51(\mathrm{~s}, 1 \mathrm{H}), 6.50(\mathrm{~d}, J=10.4 \mathrm{~Hz}, 1 \mathrm{H}), 5.01(\mathrm{~s}, 2 \mathrm{H}), 4.62(\mathrm{~s}, 2 \mathrm{H}), 4.46(\mathrm{~s}$, 2H), $3.81(\mathrm{t}, J=6.0 \mathrm{~Hz}, 2 \mathrm{H}), 3.76(\mathrm{~s}, 3 \mathrm{H}), 2.88(\mathrm{t}, J=6.4 \mathrm{~Hz}, 2 \mathrm{H}), 2.74(\mathrm{t}, J=7.2 \mathrm{~Hz}$, 2H), $2.43(\mathrm{t}, J=7.2 \mathrm{~Hz}, 2 \mathrm{H}), 1.77-1.62(\mathrm{~m}, 4 \mathrm{H}), 1.41-1.19(\mathrm{~m}, 12 \mathrm{H}) ;{ }^{13} \mathrm{C}$ NMR $(125$

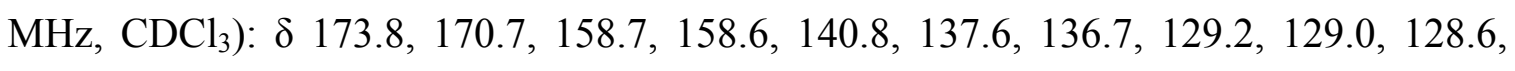
$128.3,128.3,127.8,127.6,127.4,126.4,118.4,114.2,107.9,103.6,68.2,55.3,50.0$, $48.1,45.7,33.3,32.4,29.5,29.5,29.4,29.2,26.0,25.5,24.8$; IR $\left(\mathrm{cm}^{-1}\right): 2927,2859$, 1643, 1612, 1511, 1496, 1438, 1248, 1172, 1029, 804, 697; ESI-HRMS (m/z): [M+H] ${ }^{+}$ calc'd for $\mathrm{C}_{42} \mathrm{H}_{51} \mathrm{~N}_{2} \mathrm{O}_{4}$ : 647.3843; found: 647.3872 .

\section{$N, N$-dibenzyl-3-phenylbutanamide 1ai}

Me ${ }_{\text {ConBn }}^{\text {Ph }}$ The general procedure A was followed with a reaction time of 24 hours.

1ai Purification by flash column chromatography on silica gel (hexanes/EtOAc

$=10: 1$ to $4: 1)$ afforded the title product as a viscous yellow oil in $69 \%$ yield. $\mathbf{R}_{\mathbf{f}}=0.41$ (hexanes/EtOAc $=4: 1) ;{ }^{1} \mathbf{H}$ NMR $\left(400 \mathrm{MHz}, \mathrm{CDCl}_{3}\right): \delta 7.36-7.20(\mathrm{~m}, 11 \mathrm{H}), 7.07(\mathrm{~d}, J=$ $6.8 \mathrm{~Hz}, 4 \mathrm{H}), 4.71(1 / 2 \mathrm{ABq}, J=14.8 \mathrm{~Hz}, 1 \mathrm{H}), 4.41(1 / 2 \mathrm{ABq}, J=14.4 \mathrm{~Hz}, 1 \mathrm{H}), 4.38$ $(1 / 2 \mathrm{ABq}, J=17.2 \mathrm{~Hz}, 1 \mathrm{H}), 4.28(1 / 2 \mathrm{ABq}, J=17.2 \mathrm{~Hz}, 1 \mathrm{H}), 3.52$ (sext, $J=6.8 \mathrm{~Hz}, 1 \mathrm{H})$, $2.76(\mathrm{dd}, J=14.8,7.2 \mathrm{~Hz}, 1 \mathrm{H}), 2.62(\mathrm{dd}, J=14.8,8.0 \mathrm{~Hz}, 1 \mathrm{H}), 1.35(\mathrm{~d}, J=6.8 \mathrm{~Hz}, 3 \mathrm{H})$; ${ }^{13}$ C NMR (150 MHz, $\left.\mathrm{CDCl}_{3}\right): \delta 172.4,146.3,137.4,136.7,129.0,128.7,128.6,128.3$, $127.7,127.4,127.2,126.5,110.0,50.0,48.3,41.8,37.0,21.9$; IR $\left(\mathrm{cm}^{-1}\right): 3060,2968$, 1638, 1494, 1452, 1212, 1078, 950, 698; ESI-HRMS $(\mathrm{m} / \mathrm{z}):[\mathrm{M}+\mathrm{H}]^{+}$calc'd for $\mathrm{C}_{24} \mathrm{H}_{26} \mathrm{NO}$ : 344.2014; found: 344.1999. 


\section{Aniline Synthesis}

\section{General reductive amination procedure for synthesis of $\mathbf{N}$-cyclohexylaniline $4 d$}

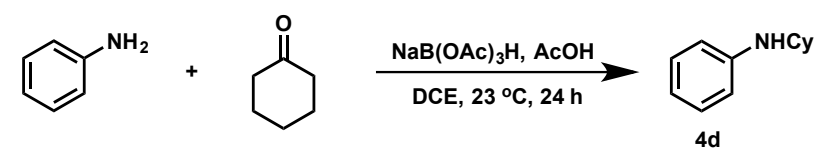

To a $0{ }^{\circ} \mathrm{C}$ solution of aniline $(0.91 \mathrm{~mL}, 10.0 \mathrm{mmol}, 1.0$ equiv) in $1,2-$ dichloroethane $(30 \mathrm{~mL}, 0.33 \mathrm{M})$ was added cyclohexanone $(1.04 \mathrm{~mL}, 10.0 \mathrm{mmol}, 1.0$ equiv) and acetic acid $(0.85 \mathrm{~mL})$. After stirring for 5 min at $0{ }^{\circ} \mathrm{C}$, sodium triacetoxyborohydride ( $4.24 \mathrm{~g}, 20.0 \mathrm{mmol}, 2.0$ equiv) was added. The resulting solution was warmed to $23{ }^{\circ} \mathrm{C}$ and stirred for $24 \mathrm{~h}$ at $23{ }^{\circ} \mathrm{C}$. The reaction mixture was quenched by slow addition of sat. aq. $\mathrm{NaHCO}_{3}(200 \mathrm{~mL})$ at $0{ }^{\circ} \mathrm{C}$, and the organic phase was separated. The aqueous phase was extracted with $\mathrm{CH}_{2} \mathrm{Cl}_{2}(3 \times 50 \mathrm{~mL})$, and the combined organic layers were washed with brine $(100 \mathrm{~mL})$, dried over anhydrous $\mathrm{Na}_{2} \mathrm{SO}_{4}$, filtered, and concentrated under reduced pressure by rotary evaporation. Purification by flash column chromatography on silica gel (hexanes/EtOAc $=20: 1$ to $8: 1$ ) afforded the title product as a colorless oil $(1.57 \mathrm{~g}, 89 \%) .{ }^{1} \mathbf{H}$ NMR $\left(400 \mathrm{MHz}, \mathrm{CDCl}_{3}\right): \delta 7.17(\mathrm{t}, J=7.2 \mathrm{~Hz}, 2 \mathrm{H})$, $6.67(\mathrm{t}, J=7.2 \mathrm{~Hz}, 1 \mathrm{H}), 6.61(\mathrm{~d}, J=7.6 \mathrm{~Hz}, 2 \mathrm{H}), 3.52(\mathrm{bs}, 1 \mathrm{H}), 3.31-3.23(\mathrm{~m}, 1 \mathrm{H}), 2.10$ $2.06(\mathrm{~m}, 2 \mathrm{H}), 1.81-1.75(\mathrm{~m}, 2 \mathrm{H}), 1.70-1.65(\mathrm{~m}, 1 \mathrm{H}), 1.44-1.33(\mathrm{~m}, 2 \mathrm{H}), 1.29-1.11(\mathrm{~m}$, $3 \mathrm{H}) ;{ }^{13} \mathbf{C}$ NMR $\left(100 \mathrm{MHz}, \mathrm{CDCl}_{3}\right): \delta$ 147.5, 129.4, 116.9, 113.2, 51.8, 33.6, 26.1, 25.2; The spectral data are consistent with those reported in the literature. ${ }^{14}$

\section{$N$-cyclohexyl-2,6-diisopropylaniline 4e CyanH}

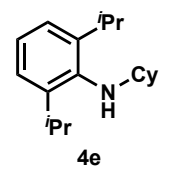

A stirred suspension of $\mathrm{NaBH}_{4}$ (8.56 g, 225 mmol, 3.0 equiv.) in 1,2dichloroethane $(125 \mathrm{~mL})$ was cooled with a $0{ }^{\circ} \mathrm{C}$ ice-water bath. To this suspension was added acetic acid (39 mL, $675 \mathrm{mmol}, 9.0$ equiv.) slowly over 15 minutes. After stirring at that temperature for 40 minutes, 2,6-diisopropylaniline (14.4 $\mathrm{mL}, 75 \mathrm{mmol}, 1.0$ equiv.) was added, followed by cyclohexanone (15.5 mL, $150 \mathrm{mmol}$, 2.0 equiv.). After warming to room temperature and stirring for an additional 39 hours, the reaction was quenched by the dropwise addition of aqueous $1 \mathrm{M} \mathrm{HCl}(20 \mathrm{~mL})$. Saturated aqueous $\mathrm{NaHCO}_{3}(30 \mathrm{~mL})$ was added slowly, followed by aqueous $2.5 \mathrm{M}$ 
$\mathrm{NaOH}(200 \mathrm{~mL})$. The organic layer was separated, and the aqueous layer was extracted with EtOAc $(3 \times 100 \mathrm{~mL})$. The combined organic layers were washed with saturated aqueous $\mathrm{NaHCO}_{3}(100 \mathrm{~mL})$, brine $(100 \mathrm{~mL})$, dried over anhydrous $\mathrm{Na}_{2} \mathrm{SO}_{4}$, filtered, and concentrated under reduced pressure by rotary evaporation. The resulting oil was placed under reduced pressure until a pink solid resulted, which was dissolved in a minimal amount of pentane at $30{ }^{\circ} \mathrm{C}$, then left at room temperature to crystallize in an Erlenmeyer flask open to air. The resulting crystals were recrystallized two more times from pentane, affording a white crystalline solid (7.35 g, $38 \%$ yield). M.P.: $67-68{ }^{\circ} \mathrm{C} ; \mathbf{R}_{\mathbf{f}}=0.37$ (hexanes/EtOAc $=20: 1) ;{ }^{1} \mathbf{H}$ NMR (400 MHz, $\left.\mathrm{CDCl}_{3}\right)$ : $\delta 7.08-6.99(\mathrm{~m}, 3 \mathrm{H}), 3.26$ (sept, $J=6.8 \mathrm{~Hz}, 2 \mathrm{H}), 2.95$ (bs, 1H), 2.76 (t, $J=10.4 \mathrm{~Hz}, 1 \mathrm{H}), 1.98(\mathrm{ad}, J=10.8 \mathrm{~Hz}, 2 \mathrm{H}), 1.75$ (ad, $J=11.2 \mathrm{~Hz}, 2 \mathrm{H}), 1.63(\mathrm{ad}, J=9.6 \mathrm{~Hz}, 1 \mathrm{H}), 1.22(\mathrm{~d}, J=6.8 \mathrm{~Hz}, 12 \mathrm{H}), 1.27-1.06$ (m, 5H); ${ }^{13} \mathrm{C}$ NMR (100 MHz, $\left.\mathrm{CDCl}_{3}\right): \delta$ 142.0, 123.5, 123.0, 59.6, 34.8, 28.0, 26.2, 26.1, 24.4; IR $\left(\mathrm{cm}^{-1}\right)$ : 2960, 2927, 2852, 1445, 1382, 1246, 1083, 792, 754; ESI-HRMS (m/z): $[\mathrm{M}+\mathrm{H}]^{+}$calc'd for $\mathrm{C}_{18} \mathrm{H}_{30} \mathrm{~N}$ : 260.2373; found: 260.2353 .

The CyanH 4e could also been synthesized via general reductive amination procedure with a reaction time of 48 hours at $50{ }^{\circ} \mathrm{C}$. Purification by flash column chromatography on silica gel (hexanes/EtOAc $=100: 1$ to $20: 1$ ) afforded the title product as a pale yellow solid in $50 \%$ yield $(1.47 \mathrm{~g})$.

\section{$N$-cyclohexyl-2,6-diisopropoxyaniline 4 f}

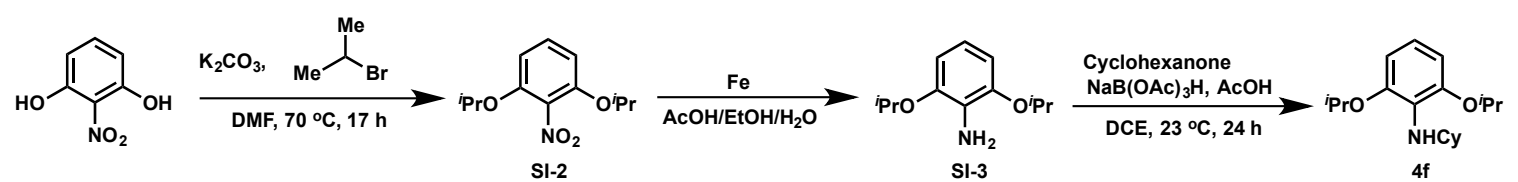

To a solution of 2-nitrobenzene-1,3-diol (3.1 g, $20.0 \mathrm{mmol}, 1.0$ equiv) in DMF $(50 \mathrm{~mL}, 0.4 \mathrm{M})$ were subsequently added $\mathrm{K}_{2} \mathrm{CO}_{3}(11.0 \mathrm{~g}, 80.0 \mathrm{mmol}, 4.0$ equiv) and 2bromopropane $\left(7.5 \mathrm{~mL}, 80 \mathrm{mmol}, 4.0\right.$ equiv). The reaction mixture was heated at $70{ }^{\circ} \mathrm{C}$ for $17 \mathrm{~h}$. The reaction mixture was then allowed to cool to room temperature, water (200 $\mathrm{mL})$ and EtOAc $(200 \mathrm{~mL})$ were added and the layers were separated. The aqueous phase was extracted with EtOAc $(3 \times 50 \mathrm{~mL})$. The combined organic layers were washed with brine, dried over anhydrous $\mathrm{Na}_{2} \mathrm{SO}_{4}$, filtered, and concentrated under reduced pressure by rotary evaporation. Purification by flash column chromatography on silica gel 
(hexanes/EtOAc $=4: 1)$ afforded SI-2 as a colorless oil $(4.70 \mathrm{~g}, 99 \%) .{ }^{1} \mathbf{H}$ NMR (400 $\mathrm{MHz}, \mathrm{CDCl}_{3}$ ): $\delta 7.14(\mathrm{t}, J=8.4 \mathrm{~Hz}, 1 \mathrm{H}), 6.48$ (d, $\left.J=8.8 \mathrm{~Hz}, 2 \mathrm{H}\right), 4.49$ (sept, $J=6.0 \mathrm{~Hz}$, $2 \mathrm{H}), 1.22(\mathrm{~d}, J=6.0 \mathrm{~Hz}, 12 \mathrm{H}) ;{ }^{13} \mathbf{C}$ NMR $\left(100 \mathrm{MHz}, \mathrm{CDCl}_{3}\right): \delta 150.5,130.6,106.7$, 72.5, 22.0; The spectral data are consistent with those reported in the literature. ${ }^{15}$

To a solution of SI-2 (2.70 g, $20.0 \mathrm{mmol}, 1.0$ equiv) in AcOH $(100 \mathrm{~mL}), \mathrm{EtOH}$ $(100 \mathrm{~mL})$, and $\mathrm{H}_{2} \mathrm{O}(50.0 \mathrm{~mL})$ was added iron powder $(9.0 \mathrm{~g}, 160 \mathrm{mmol}, 8.0$ equiv). The reaction mixture was heated at $90{ }^{\circ} \mathrm{C}$ for $12 \mathrm{~h}$. After cooling to the room temperature, the reaction mixture was poured onto ice basified with solid $\mathrm{Na}_{2} \mathrm{CO}_{3}$. The aqueous phase was extracted with EtOAc $(3 \times 200 \mathrm{~mL})$. The combined organic layers were washed with brine, dried over anhydrous $\mathrm{Na}_{2} \mathrm{SO}_{4}$, filtered, and concentrated under reduced pressure by rotary evaporation. Purification by flash column chromatography on silica gel (hexanes/EtOAc $=10: 1)$ afforded SI-3 as a yellow oil $(2.85 \mathrm{~g}, 68 \%) . \mathbf{R}_{\mathbf{f}}=0.29$ (hexanes/EtOAc $=10: 1) ;{ }^{1} \mathbf{H}$ NMR $\left(400 \mathrm{MHz}, \mathrm{CDCl}_{3}\right): \delta 6.62(\mathrm{t}, J=7.6 \mathrm{~Hz}, 1 \mathrm{H}), 6.51$ (d, $J=8.0 \mathrm{~Hz}, 2 \mathrm{H}), 4.52$ (sept, $J=6.0 \mathrm{~Hz}, 2 \mathrm{H}), 3.83$ (s, 2H), 1.35 (d, $J=6.4 \mathrm{~Hz}, 12 \mathrm{H}$ ); ${ }^{13}$ C NMR (100 MHz, $\left.\mathrm{CDCl}_{3}\right): \delta 146.0,128.1,116.7,107.0,70.9,22.5$; IR $\left(\mathrm{cm}^{-1}\right): 3469$, 2974, 2928, 1603, 1562, 1497, 1475, 1288, 1172, 1114, 716; ESI-HRMS (m/z): [M+H] ${ }^{+}$ calc'd for $\mathrm{C}_{12} \mathrm{H}_{20} \mathrm{NO}_{2}$ : 210.1489; found: 210.1462 .

General reductive amination procedure was followed with a reaction time of 24 hours. Purification by flash column chromatography on silica gel (hexanes/EtOAc $=20: 1$ to $10: 1)$ afforded the title product as a yellow oil in $60 \%$ yield $(1.75 \mathrm{~g})$. $\mathbf{R}_{\mathbf{f}}=0.37$ (hexanes/EtOAc $=10: 1) ;{ }^{1} \mathbf{H}$ NMR $\left(400 \mathrm{MHz}, \mathrm{CDCl}_{3}\right): \delta 6.69(\mathrm{t}, J=8.4 \mathrm{~Hz}, 1 \mathrm{H}), 6.48(\mathrm{~d}$, $J=8.0 \mathrm{~Hz}, 2 \mathrm{H}$ ), 4.52 (sept, $J=6.0 \mathrm{~Hz}, 2 \mathrm{H}), 3.81$ (bs, 1H), 3.60-3.53 (m, 1H), 1.93-1.90 (m, 2H), 1.73-1.69 (m, 2H), 1.59-1.55 (m, 1H), $1.33(\mathrm{~d}, J=6.0 \mathrm{~Hz}, 12 \mathrm{H}), 1.30-1.02(\mathrm{~m}$, 5H); ${ }^{13} \mathbf{C}$ NMR $\left(100 \mathrm{MHz}, \mathrm{CDCl}_{3}\right): \delta 149.3,129.0,119.0,107.5,70.5,53.7,34.5,26.3$, 25.3, 22.5; IR $\left(\mathrm{cm}^{-1}\right): 2973,2926,2850,1597,1482,1450,1370,1224,1111,1040,720$; ESI-HRMS (m/z): $[\mathrm{M}+\mathrm{H}]^{+}$calc'd for $\mathrm{C}_{18} \mathrm{H}_{30} \mathrm{NO}_{2}: 292.2271$; found: 292.2158 .

\section{$N, 2,6-t r i i s o p r o p y l a n i l i n e ~ 4 g$}

$\begin{array}{ll}\text { (he } & \text { General reductive amination procedure was followed with a reaction time of } \\ 4 \mathrm{~g} & 24 \text { hours. Purification by flash column chromatography on silica gel } \\ \text { (hexanes/EtOAc }=30: 1) \text { afforded the title product as a colorless oil in } 67 \%\end{array}$ 
yield $(1.47 \mathrm{~g}) . \mathbf{R}_{\mathbf{f}}=0.37($ hexanes $/$ EtOAc $=20: 1) ;{ }^{1} \mathbf{H}$ NMR $\left(400 \mathrm{MHz}, \mathrm{CDCl}_{3}\right): \delta 7.11-$ $7.03(\mathrm{~m}, 3 \mathrm{H}), 3.27$ (sept, $J=6.8 \mathrm{~Hz}, 2 \mathrm{H}), 3.21$ (sept, $J=6.4 \mathrm{~Hz}, 1 \mathrm{H}), 1.23$ (d, $J=6.8 \mathrm{~Hz}$, $12 \mathrm{H}), 1.14(\mathrm{~d}, J=6.4 \mathrm{~Hz}, 6 \mathrm{H}) ;{ }^{13} \mathrm{C} \mathbf{N M R}\left(100 \mathrm{MHz}, \mathrm{CDCl}_{3}\right): \delta$ 142.2, $142.0,123.5$, 123.1, 51.5, 27.9, 24.3, 23.6; IR (cm $\left.{ }^{-1}\right): 2960,2926,2867,1483,1442,1363,1198,1120$, 793, 751; ESI-HRMS (m/z): [M+H] ${ }^{+}$calc'd for $\mathrm{C}_{15} \mathrm{H}_{26} \mathrm{~N}$ : 220.2060; found: 220.2048.

\section{$N$-(tert-butyl)-2,6-diisopropylaniline $4 \mathrm{~h}$}

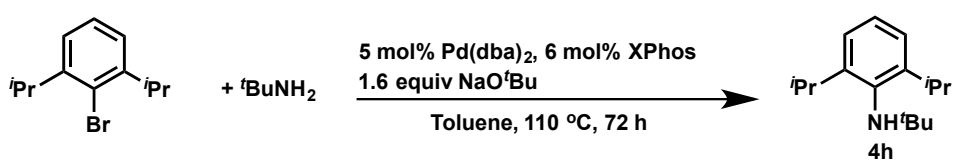

Aniline 4h was synthesized via Buchwald-Hartwig amination: To a solution of 2bromo-1,3-diisopropylbenzene $(0.90 \mathrm{~g}, 3.7 \mathrm{mmol}, 1.0$ equiv) in toluene $(7.0 \mathrm{~mL}, 0.53 \mathrm{M})$ was subsequently added ${ }^{t} \mathrm{BuNH}_{2}\left(0.58 \mathrm{~mL}, 5.6 \mathrm{mmol}, 1.5\right.$ equiv), $\mathrm{NaO}^{t} \mathrm{Bu}(0.57 \mathrm{~g}, 6.0$ mmol, 1.6 equiv), Pd(dba) 2 (0.11 g, $0.19 \mathrm{mmol}, 0.05$ equiv) and XPhos (0.11 g, 0.22 mmol, 0.06 equiv). The reaction mixture was heated at $110^{\circ} \mathrm{C}$ for $72 \mathrm{~h}$. After cooling to the room temperature, the reaction mixture was quenched with addition of of sat. aq. $\mathrm{NH}_{4} \mathrm{Cl}(20 \mathrm{~mL})$, diluted with EtOAc $(20 \mathrm{~mL})$, and the organic phase was separated. The aqueous phase was extracted with EtOAc $(3 \times 10 \mathrm{~mL})$ and the combined organic layers were washed with brine $(50 \mathrm{~mL})$, dried over anhydrous $\mathrm{Na}_{2} \mathrm{SO}_{4}$, filtered, and concentrated under reduced pressure by rotary evaporation. Purification by flash column chromatography on silica gel (hexanes/EtOAc $=20: 1$ ) afforded the title product as a yellow oil (0.73 g, 84\%). $\mathbf{R}_{\mathbf{f}}=0.37$ (hexanes/EtOAc $\left.=20: 1\right) ;{ }^{1} \mathbf{H}$ NMR (400 MHz, $\mathrm{CDCl}_{3}$ ): $\delta 7.10-7.09(\mathrm{~m}, 3 \mathrm{H}), 3.54$ (sept, $\left.J=6.8 \mathrm{~Hz}, 2 \mathrm{H}\right), 2.77$ (bs, $\left.1 \mathrm{H}\right), 1.18$ (d, $J=6.8$ $\mathrm{Hz}, 12 \mathrm{H}), 1.18$ (s, 9H); ${ }^{13} \mathbf{C}$ NMR $\left(100 \mathrm{MHz}, \mathrm{CDCl}_{3}\right): \delta 146.6,139.9,124.6,123.2,54.0$, 30.9, 28.4, 24.4; IR $\left(\mathrm{cm}^{-1}\right): 2962,2931,2867,1464,1387,1362,1253,1197,803,775$;

ESI-HRMS (m/z): [M+H] $]^{+}$calc'd for $\mathrm{C}_{16} \mathrm{H}_{28} \mathrm{~N}$ : 234.2217; found: 234.2200 .

\section{2,6-diisopropyl- $N$-phenylaniline $4 \mathbf{i}$}
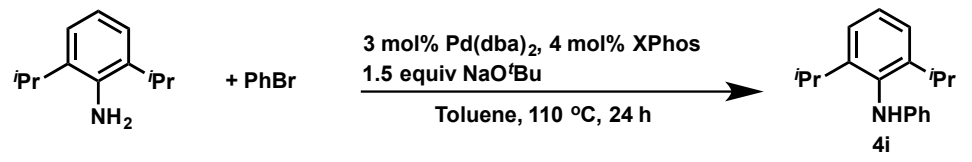
Aniline 4i was synthesized via Buchwald-Hartwig amination: To a solution of bromobenzene $(0.86 \mathrm{~mL}, 8.0 \mathrm{mmol}, 1.0$ equiv) in toluene $(30 \mathrm{~mL}, 0.27 \mathrm{M})$ was subsequently added 2,6-diisopropylaniline (2.12 mL, $11.2 \mathrm{mmol}, 1.4$ equiv), $\mathrm{NaO}^{t} \mathrm{Bu}$ (1.15 g, $12.0 \mathrm{mmol}, 1.5$ equiv), $\mathrm{Pd}(\mathrm{dba})_{2}(0.14 \mathrm{~g}, 0.24 \mathrm{mmol}, 0.03$ equiv) and XPhos (0.15 g, $0.32 \mathrm{mmol}, 0.04$ equiv). The reaction mixture was heated at $110{ }^{\circ} \mathrm{C}$ for $24 \mathrm{~h}$. After cooling to the room temperature, the reaction mixture was quenched with addition of of sat. aq. $\mathrm{NH}_{4} \mathrm{Cl}(20 \mathrm{~mL})$, diluted with EtOAc $(20 \mathrm{~mL})$, and the organic phase was separated. The aqueous phase was extracted with EtOAc $(3 \times 10 \mathrm{~mL})$ and the combined organic layers were washed with brine $(50 \mathrm{~mL})$, dried over anhydrous $\mathrm{Na}_{2} \mathrm{SO}_{4}$, filtered, and concentrated under reduced pressure by rotary evaporation. Purification by flash column chromatography on silica gel (hexanes/EtOAc $=30: 1$ ) afforded the title product as a yellow soild (2.01 g, 99\%). M.P.: $43^{\circ} \mathrm{C} ; \mathbf{R}_{\mathbf{f}}=0.37$ (hexanes/EtOAc $\left.=20: 1\right) ;{ }^{1} \mathbf{H}$ NMR $\left(400 \mathrm{MHz}, \mathrm{CDCl}_{3}\right): \delta 7.35-7.26(\mathrm{~m}, 1 \mathrm{H}), 7.25(\mathrm{~d}, J=8.4 \mathrm{~Hz}, 2 \mathrm{H}), 7.17(\mathrm{t}, J=8.4 \mathrm{~Hz}$, 2H), 6.74 (t, $J=7.2 \mathrm{~Hz}, 1 \mathrm{H}), 6.51$ (d, $J=7.6 \mathrm{~Hz}, 2 \mathrm{H}), 5.14$ (s, 1H), 3.24 (sept, $J=6.8$ $\mathrm{Hz}, 2 \mathrm{H}), 1.17(\mathrm{~d}, J=6.8 \mathrm{~Hz}, 12 \mathrm{H}) ;{ }^{13} \mathbf{C} \mathbf{N M R}\left(100 \mathrm{MHz}, \mathrm{CDCl}_{3}\right): \delta 148.2,147.7,135.2$, 129.3, 127.3, 124.0, 117.8, 113.1, 28.3, 24.0; IR ( $\left.\mathrm{cm}^{-1}\right): 3403,2960,2868,1602,1497$, 1459, 1309, 1177, 869, 804; ESI-HRMS (m/z): $[\mathrm{M}+\mathrm{H}]^{+}$calc'd for $\mathrm{C}_{18} \mathrm{H}_{24} \mathrm{~N}: 254.1909$; found: 254.1890 . 


\section{Amide and Lactam Dehydrogenation}

\section{Stock solutions:}

Zinc chloride $\left(0.5 \mathrm{M}\right.$ in THF): Finely powdered anhydrous $\mathrm{ZnCl}_{2}(0.68 \mathrm{~g}, 5.0$ mmol) was weighed into a 50-mL, flame-dried flask in the glove box in an inert atmosphere. The flask was taken out of the glove box and placed under vacuum. The flask was heated with a heat gun for 2 min under vacuum and then backfilled with nitrogen (This process was repeated 3 times.). After the flask was cooled down to room temperature, the flask was backfilled with nitrogen, THF $(10 . \mathrm{mL})$ was added and the suspension was vigorously stirred for $1.5 \mathrm{~h}$ before it was used.

$\mathrm{ZnCl}_{2}$ (1.9 $\mathrm{M}$ in 2-MeTHF) could also be directly used as received from SigmaAldrich.

$[\mathrm{Pd}(\text { allyl }) \mathrm{Cl}]_{2}$, allyl acetate stock solution A: $[\mathrm{Pd}(\text { allyl }) \mathrm{Cl}]_{2}(27 \mathrm{mg}, 0.075 \mathrm{mmol})$ was weighed into a flame dried vial, the vial was evacuated and backfilled with nitrogen (this process was repeated 3 times). Allyl acetate $(0.39 \mathrm{~mL}, 0.36 \mathrm{~g}, 3.6 \mathrm{mmol})$ and THF $(2.6 \mathrm{~mL})$ were added sequentially and the solution was stirred for 0.5 hour.

$[\mathrm{Pd}(\text { allyl }) \mathrm{Cl}]_{2}$ and allyl acetate stock solution $\mathrm{B}:[\mathrm{Pd}(\text { allyl }) \mathrm{Cl}]_{2}(54.8 \mathrm{mg}, 0.15$ mmol) was weighed into a flame-dried vial; the vial was evacuated and backfilled with nitrogen (this process was repeated 3 times). Allyl acetate $(0.39 \mathrm{~mL}, 0.36 \mathrm{~g}, 3.6 \mathrm{mmol})$ and THF $(2.6 \mathrm{~mL})$ were added sequentially and the solution was stirred for 0.5 hour.

\section{Addition of amides or lactam:}

Amides and lactams were dissolved in THF $(0.5-2.0 \mathrm{~mL})$ depending on the solubility, and added dropwise via syringe unless otherwise noted. The transfers were quantitated by rinsing with additional THF $(0.5-1.0 \mathrm{~mL})$. 


\section{$N, N$-dibenzyl-3-methylbut-2-enamide 2a}

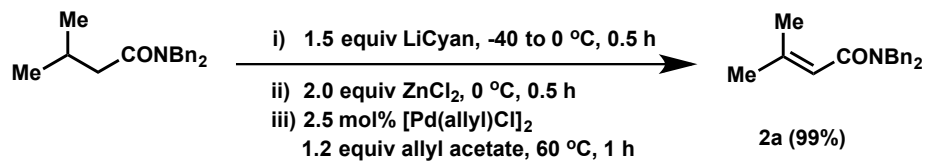

To a $-40{ }^{\circ} \mathrm{C}$ solution of $\mathrm{N}$-cyclohexyl-2,6-diisopropylaniline $(3.89 \mathrm{~g}, 15.0 \mathrm{mmol}$, 1.50 equiv) in THF $(100 \mathrm{~mL}, 0.167 \mathrm{M})$ was added $n$-BuLi $(2.5 \mathrm{M}$ in hexanes, $6.00 \mathrm{~mL}$, $15.0 \mathrm{mmol}, 1.50$ equiv). After 3-5 mins, the reaction mixture became cloudy, and was stirred for $1 \mathrm{~h}$. Amide $1 \mathrm{a}(2.81 \mathrm{~g}, 10.0 \mathrm{mmol}, 1.00$ equiv) was added dropwise into the resulting suspension and the mixture became clear immediately. The resulting solution was moved into an ice-water bath and stirred for $30 \mathrm{~min} . \mathrm{ZnCl}_{2}(0.5 \mathrm{M}$ in THF, $40.0 \mathrm{~mL}$, $20.0 \mathrm{mmol}, 2.00$ equiv) was added and stirred for $30 \mathrm{~min}$. The stock solution of $[\mathrm{Pd}(\text { allyl }) \mathrm{Cl}]_{2}(91.5 \mathrm{mg}, 0.25 \mathrm{mmol}, 0.025$ equiv) and allyl acetate $(1.20 \mathrm{~g}, 12.0 \mathrm{mmol}$, 1.2 equiv) in THF (10.0 mL) was next added at the same temperature. The reaction mixture was placed into a preheated $60{ }^{\circ} \mathrm{C}$ oil bath and stirred for $1 \mathrm{~h}$. The resulting mixture was cooled to room temperature and stopped with the addition of sat. aq. $\mathrm{NH}_{4} \mathrm{Cl}$ $(50 \mathrm{~mL})$, diluted with EtOAc $(50 \mathrm{~mL})$, and the organic phase was separated. The aqueous phase was extracted with EtOAc $(3 \times 30 \mathrm{~mL})$ and the combined organic layers were washed with brine $(100 \mathrm{~mL})$, dried over anhydrous $\mathrm{Na}_{2} \mathrm{SO}_{4}$, filtered, and concentrated under reduced pressure by rotary evaporation. Purification by flash column chromatography on silica gel (hexanes/EtOAc $=1: 0$ to $3: 1$ ) afforded the title product as an off white solid (2.75 g, 99\%) and recycled the CyanH 4e (3.02 g, 78\%). M.P.: 54-55 ${ }^{\circ} \mathrm{C} ; \mathbf{R}_{\mathbf{f}}=0.33$ (hexanes/EtOAc $\left.=4: 1\right) ;{ }^{1} \mathbf{H} \mathbf{N M R}\left(400 \mathrm{MHz}, \mathrm{CDCl}_{3}\right): \delta 7.38-7.24(\mathrm{~m}, 8 \mathrm{H})$, $7.17(\mathrm{~d}, J=7.2 \mathrm{~Hz}, 2 \mathrm{H}), 5.95(\mathrm{~s}, 1 \mathrm{H}), 4.60$ (s, 2H), 4.46 (s, 2H), 2.05 (s, 3H), 1.83 (s, $3 \mathrm{H}) ;{ }^{13} \mathrm{C}$ NMR $\left(100 \mathrm{MHz}, \mathrm{CDCl}_{3}\right): \delta 168.8,148.2,137.5,136.8,128.9,128.6,128.4$, 127.6 127.3, 126.8, 117.7, 50.3, 47.2, 26.5, 20.5; IR $\left(\mathrm{cm}^{-1}\right): 2919,1645,1629,1494$, 1451, 1355, 1173, 963, 740; ESI-HRMS (m/z): [M+H] $]^{+}$calc'd for $\mathrm{C}_{19} \mathrm{H}_{22} \mathrm{NO}$ : 280.1696; found: 280.1711. (Note, the isolated yield of 2a was $96 \%$ when the reaction was conducted on $0.2 \mathrm{mmol}$ scale.) 


\section{(E)-1-morpholino-3-phenylprop-2-en-1-one 2b}

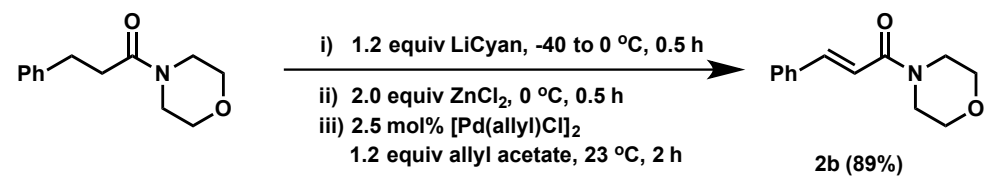

To a $-40{ }^{\circ} \mathrm{C}$ solution of $\mathrm{N}$-cyclohexyl-2,6-diisopropylaniline $(156 \mathrm{mg}, 0.60 \mathrm{mmol}$, 1.2 equiv) in THF (2.0 mL, $0.30 \mathrm{M})$ was added $n$-BuLi (2.5 M in hexanes, $0.24 \mathrm{~mL}, 0.60$ mmol, 1.2 equiv). After $3-5$ mins, the reaction mixture became cloudy, and was stirred for $1 \mathrm{~h}$. Amide $1 \mathbf{b}(110 \mathrm{mg}, 0.50 \mathrm{mmol}, 1.0$ equiv) was added dropwise into the reaction mixture and the mixture became clear immediately. The resulting solution was moved into an ice-water bath and stirred for $30 \mathrm{~min}$. $\mathrm{ZnCl}_{2}(0.5 \mathrm{M}$ in THF, $2.0 \mathrm{~mL}, 1.0 \mathrm{mmol}$, 2.0 equiv) was added and stirred for $30 \mathrm{~min}$. The stock solution of $[\mathrm{Pd}(\text { allyl }) \mathrm{Cl}]_{2}(4.6 \mathrm{mg}$, $0.125 \mathrm{mmol}, 0.025$ equiv) and allyl acetate $(60 \mathrm{mg}, 0.60 \mathrm{mmol}, 1.2$ equiv) in THF (0.5 $\mathrm{mL}$ ) was next added at the same temperature. The reaction mixture was removed from the ice bath and stirred for $2 \mathrm{~h}$ at $23{ }^{\circ} \mathrm{C}$. The resulting mixture was stopped with addition of sat. aq. $\mathrm{NH}_{4} \mathrm{Cl}(8 \mathrm{~mL})$, diluted with EtOAc $(8 \mathrm{~mL})$, and the organic phase was separated. The aqueous phase was extracted with EtOAc $(3 \times 8 \mathrm{~mL})$ and the combined organic layers were washed with brine $(20 \mathrm{~mL})$, dried over anhydrous $\mathrm{Na}_{2} \mathrm{SO}_{4}$, filtered, and concentrated under reduced pressure by rotary evaporation. Purification by flash column chromatography on silica gel (hexanes/EtOAc $=8: 1$ to $1: 2$ ) afforded the title product as an off white solid (97 $\mathrm{mg}, 89 \%$ ). In addition, CyanH was recovered in 99\% yield (155 mg). M.P.: $89{ }^{\circ} \mathrm{C} ; \mathbf{R}_{\mathbf{f}}=0.30$ (hexanes/EtOAc $\left.=1: 2\right) ;{ }^{1} \mathbf{H}$ NMR $(400 \mathrm{MHz}$, $\left.\mathrm{CDCl}_{3}\right): \delta 7.67(\mathrm{~d}, J=15.6 \mathrm{~Hz}, 1 \mathrm{H}), 7.51-7.48(\mathrm{~m}, 2 \mathrm{H}), 7.37-7.30(\mathrm{~m}, 3 \mathrm{H}), 6.83(\mathrm{~d}, J=$ $15.6 \mathrm{~Hz}, 1 \mathrm{H}), 3.69-3.64(\mathrm{~m}, 8 \mathrm{H}) ;{ }^{13} \mathbf{C} \mathbf{N M R}\left(100 \mathrm{MHz}, \mathrm{CDCl}_{3}\right): \delta 165.5,143.1,135.1$, 129.7, 128.8, 127.8, 116.6, 66.8, 46.2, 42.5; IR $\left(\mathrm{cm}^{-1}\right): 2965,2856,1643,1596,1494$, 1453, 1224, 1113, 972, 762; ESI-HRMS (m/z): $[\mathrm{M}+\mathrm{H}]^{+}$calc'd for $\mathrm{C}_{13} \mathrm{H}_{16} \mathrm{NO}_{2}$ : 218.1176; found: 218.1148. The spectral data are consistent with those reported in the literature. $^{16}$ 


\section{(R)-5-Benzyl-1-cinnamoylpyrrolidin-2-one 2c}
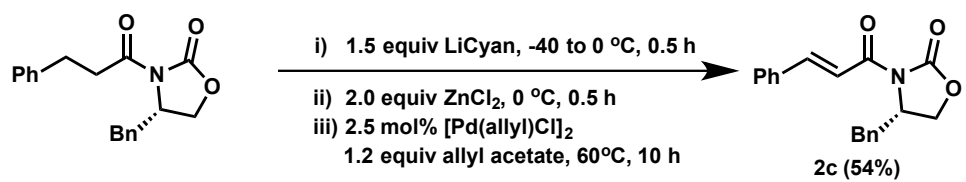

To a $-40{ }^{\circ} \mathrm{C}$ solution of $N$-cyclohexyl-2,6-diisopropylaniline (194 $\mathrm{mg}, 0.75 \mathrm{mmol}$, 1.5 equiv) in THF (3.0 mL, $0.30 \mathrm{M})$ was added $n$-BuLi $(2.5 \mathrm{M}$ in hexanes, $0.30 \mathrm{~mL}, 0.75$ mmol, 1.5 equiv). After $3-5$ mins, the reaction mixture became cloudy, and was stirred for $1 \mathrm{~h}$. Amide $1 \mathrm{c}(155 \mathrm{mg}, 0.50 \mathrm{mmol}, 1.0$ equiv) was added dropwise into the reaction mixture and the mixture became clear immediately. The resulting solution was moved into an ice-water bath and stirred for $30 \mathrm{~min}$. $\mathrm{ZnCl}_{2}(0.5 \mathrm{M}$ in THF, $2.0 \mathrm{~mL}, 0.5 \mathrm{mmol}$, 2.0 equiv) was added and stirred for $30 \mathrm{~min}$. The stock solution of [Pd(allyl)Cl $]_{2}(4.6 \mathrm{mg}$, $0.0125 \mathrm{mmol}, 0.025$ equiv) and allyl acetate $(60 \mathrm{mg}, 0.60 \mathrm{mmol}, 1.2$ equiv) in THF (0.50 $\mathrm{mL}$ ) was next added at the same temperature. The reaction mixture was placed into a preheated $60{ }^{\circ} \mathrm{C}$ oil bath and stirred for $10 \mathrm{~h}$. The resulting mixture was cooled to room temperature and stopped with the addition of sat. aq. $\mathrm{NH}_{4} \mathrm{Cl}(8 \mathrm{~mL})$, diluted with EtOAc $(8 \mathrm{~mL})$, and the organic phase was separated. The aqueous phase was extracted with EtOAc $(3 \times 8 \mathrm{~mL})$ and the combined organic layers were washed with brine $(20 \mathrm{~mL})$, dried over anhydrous $\mathrm{Na}_{2} \mathrm{SO}_{4}$, filtered, and concentrated under reduced pressure by rotary evaporation. Purification by flash column chromatography on silica gel (hexanes/EtOAc $=10: 1$ to $3: 1)$ afforded the title product as a white solid (82 mg, 54\%). M.P.: 120-122 ${ }^{\circ} \mathrm{C} ; \mathbf{R}_{\mathbf{f}}=0.38$ (hexanes/EtOAc $\left.=3: 1\right) ;[\alpha]_{\mathrm{D}}^{23}+56.7\left(c, 0.91, \mathrm{CHCl}_{3}\right) ;{ }^{1} \mathbf{H}$ NMR $(400 \mathrm{MHz}$, $\left.\mathrm{CDCl}_{3}\right): \delta$ 7.93-7.92 (m, 2H), 7.65-7.62 (m, 2H), 7.41-7.23 (m, 8H), 4.83-4.77 (m, 1H), $4.27-4.18(\mathrm{~m}, 2 \mathrm{H}), 3.37(\mathrm{dd}, J=13.6,3.2 \mathrm{~Hz}, 1 \mathrm{H}), 2.85(\mathrm{dd}, J=13.6,9.6 \mathrm{~Hz}, 2 \mathrm{H}) ;{ }^{13} \mathrm{C}$ NMR $\left(100 \mathrm{MHz}, \mathrm{CDCl}_{3}\right): \delta 165.3,153.6,146.6,135.5,134.7,130.8,129.6,129.1$, 129.0, 128.8, 127.5, 66.3, 55.5, 38.1; IR ( $\left.\mathrm{cm}^{-1}\right): 2923,1778,1673,1617,1498,1348$, 1212, 757. ESI-HRMS (m/z): $[\mathrm{M}+\mathrm{H}]^{+}$calc'd for $\mathrm{C}_{19} \mathrm{H}_{18} \mathrm{NO}_{3}$ : 308.1281; found: 308.1275. The spectral data are consistent with those reported in the literature. ${ }^{17}$ 
tert-Butyl 4-cinnamoylpiperazine-1-carboxylate 2d

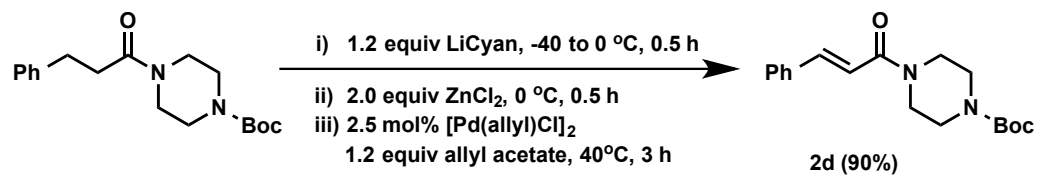

To a $-40{ }^{\circ} \mathrm{C}$ solution of $N$-cyclohexyl-2,6-diisopropylaniline $(78 \mathrm{mg}, 0.30 \mathrm{mmol}$, 1.2 equiv) in THF (2.0 mL, $0.15 \mathrm{M})$ was added $n$-BuLi (2.5 M in hexanes, $0.12 \mathrm{~mL}, 0.30$ mmol, 1.2 equiv). After 3-5 mins, the reaction mixture became cloudy, and was stirred for $1 \mathrm{~h}$. Amide $1 \mathrm{~d}$ ( $80 \mathrm{mg}, 0.25 \mathrm{mmol}, 1.0$ equiv) was added dropwise into the reaction mixture and the mixture became clear immediately. The resulting solution was moved into an ice-water bath and stirred for $30 \mathrm{~min}$. $\mathrm{ZnCl}_{2}(0.5 \mathrm{M}$ in THF, $1.0 \mathrm{~mL}, 0.5 \mathrm{mmol}$, 2.0 equiv) was added and stirred for $30 \mathrm{~min}$. The stock solution of $\left[\mathrm{Pd}(\right.$ allyl $) \mathrm{Cl}_{2}(2.3 \mathrm{mg}$, $0.0063 \mathrm{mmol}, 0.025$ equiv) and allyl acetate $(30 \mathrm{mg}, 0.30 \mathrm{mmol}, 1.2$ equiv) in THF (0.25 $\mathrm{mL}$ ) was next added at the same temperature. The reaction mixture was placed into a preheated $40{ }^{\circ} \mathrm{C}$ oil bath and stirred for $3 \mathrm{~h}$. The resulting mixture was cooled to room temperature and stopped with the addition of sat. aq. $\mathrm{NH}_{4} \mathrm{Cl}(8 \mathrm{~mL})$, diluted with EtOAc $(8 \mathrm{~mL})$, and the organic phase was separated. The aqueous phase was extracted with EtOAc $(3 \times 8 \mathrm{~mL})$ and the combined organic layers were washed with brine $(20 \mathrm{~mL})$, dried over anhydrous $\mathrm{Na}_{2} \mathrm{SO}_{4}$, filtered, and concentrated under reduced pressure by rotary evaporation. Purification by flash column chromatography on silica gel (hexanes/EtOAc $=3: 1$ to $1: 1)$ afforded the title product as a white solid $(71 \mathrm{mg}, 90 \%)$. M.P.: $127-129{ }^{\circ} \mathrm{C}$; $\mathbf{R}_{\mathbf{f}}=0.33$ (hexanes/EtOAc $\left.=1: 1\right) ;{ }^{1} \mathbf{H}$ NMR $\left(400 \mathrm{MHz}, \mathrm{CDCl}_{3}\right): \delta 7.67(\mathrm{~d}, J=15.6 \mathrm{~Hz}$, 1H), 7.50 (dd, $J=7.2,1.6 \mathrm{~Hz}, 2 \mathrm{H}), 7.38-7.33(\mathrm{~m}, 3 \mathrm{H}), 6.85(\mathrm{~d}, J=15.2 \mathrm{~Hz}, 1 \mathrm{H}), 3.68$ (bs, 2H), 3.62 (abs, 2H), 3.46 (abs, 4H), 1.46 (s, 9H); ${ }^{13}$ C NMR (100 MHz, $\left.\mathrm{CDCl}_{3}\right): \delta$ $165.7,154.6,143.3,135.1,129.8,128.9,127.9,116.8,80.4,45.7,43.7,42.1,28.4$; IR $\left(\mathrm{cm}^{-1}\right): 2976,1683,1638,1607,1458,1425,1362,1236,1173,761 ;$ ESI-HRMS (m/z): $[\mathrm{M}+\mathrm{Na}]^{+}$calc'd for $\mathrm{C}_{18} \mathrm{H}_{24} \mathrm{~N}_{2} \mathrm{O}_{3} \mathrm{Na}$ : 339.1680; found: 339.1677 . 


\section{$N, N$-dibenzylcinnamamide $2 \mathrm{e}$}

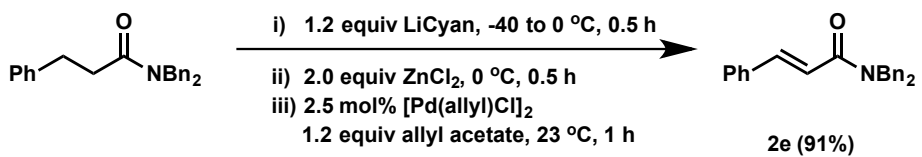

To a $-40{ }^{\circ} \mathrm{C}$ solution of $N$-cyclohexyl-2,6-diisopropylaniline $(156 \mathrm{mg}, 0.60 \mathrm{mmol}$, 1.2 equiv) in THF (2.0 mL, $0.30 \mathrm{M})$ was added $n$-BuLi (2.5 M in hexanes, $0.24 \mathrm{~mL}, 0.60$ mmol, 1.2 equiv). After 3-5 mins, the reaction mixture became cloudy, and was stirred for $1 \mathrm{~h}$. Amide 1e (165 mg, $0.50 \mathrm{mmol}, 1.0$ equiv) was added dropwise into the reaction mixture and the mixture became clear immediately. The resulting solution was moved into an ice-water bath and stirred for $30 \mathrm{~min}$. $\mathrm{ZnCl}_{2}(0.5 \mathrm{M}$ in THF, $2.0 \mathrm{~mL}, 1.0 \mathrm{mmol}$, 2.0 equiv) was added and stirred for $30 \mathrm{~min}$. The stock solution of $[\mathrm{Pd}(\text { allyl }) \mathrm{Cl}]_{2}(4.6 \mathrm{mg}$, $0.125 \mathrm{mmol}, 0.025$ equiv) and allyl acetate $(60 \mathrm{mg}, 0.60 \mathrm{mmol}, 1.2$ equiv) in THF (0.5 $\mathrm{mL}$ ) was next added at the same temperature. The reaction mixture was removed from the ice bath and stirred for $1 \mathrm{~h}$ at $23{ }^{\circ} \mathrm{C}$. The resulting mixture was stopped with addition of sat. aq. $\mathrm{NH}_{4} \mathrm{Cl}(8 \mathrm{~mL})$, diluted with EtOAc $(8 \mathrm{~mL})$, and the organic phase was separated. The aqueous phase was extracted with EtOAc $(3 \times 8 \mathrm{~mL})$ and the combined organic layers were washed with brine $(20 \mathrm{~mL})$, dried over anhydrous $\mathrm{Na}_{2} \mathrm{SO}_{4}$, filtered, and concentrated under reduced pressure by rotary evaporation. Purification by flash column chromatography on silica gel (hexanes/EtOAc $=10: 1$ to $4: 1$ ) afforded the title product as an off white soild (149 $\mathrm{mg}, 91 \%)$. M.P.: $126-128{ }^{\circ} \mathrm{C} ; \mathbf{R}_{\mathbf{f}}=0.39$ (hexanes/EtOAc $=4: 1) ;{ }^{1} \mathbf{H}$ NMR $\left(400 \mathrm{MHz}, \mathrm{CDCl}_{3}\right): \delta 7.89(\mathrm{~d}, J=15.2 \mathrm{~Hz}, 1 \mathrm{H}), 7.49$ $7.47(\mathrm{~m}, 2 \mathrm{H}), 7.41-7.30(\mathrm{~m}, 11 \mathrm{H}), 7.25(\mathrm{~d}, J=7.2 \mathrm{~Hz}, 2 \mathrm{H}), 6.93(\mathrm{~d}, J=15.6 \mathrm{~Hz}, 1 \mathrm{H})$, 4.74 (s, 2H), 4.62 (s, 2H); ${ }^{13} \mathrm{C}$ NMR (100 MHz, $\left.\mathrm{CDCl}_{3}\right): \delta 167.2,143.9,137.4,136.8$, $135.2,129.8,129.0,128.8,128.7,128.4,127.9,127.8,127.5,126.6,117.3,50.1$, 48.9; IR $\left(\mathrm{cm}^{-1}\right):$ 3052, 2923, 1641, 1592, 1494, 1459, 1196, 767; ESI-HRMS (m/z): $[\mathrm{M}+\mathrm{H}]^{+}$ calc'd for $\mathrm{C}_{23} \mathrm{H}_{22} \mathrm{NO}$ : 328.1702 ; found: 328.1729 . The spectral data are consistent with those reported in the literature. ${ }^{18}$ 


\section{(E)-N,N-dibenzyl-3-(4-methoxyphenyl)acrylamide $2 f$}

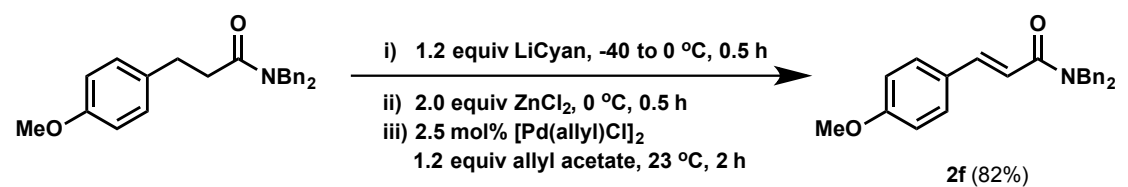

To a $-40{ }^{\circ} \mathrm{C}$ solution of $\mathrm{N}$-cyclohexyl-2,6-diisopropylaniline $(156 \mathrm{mg}, 0.60 \mathrm{mmol}$, 1.2 equiv) in THF (2.0 mL, $0.30 \mathrm{M})$ was added $n-\mathrm{BuLi}(2.5 \mathrm{M}$ in hexanes, $0.24 \mathrm{~mL}, 0.60$ mmol, 1.2 equiv). After 3-5 mins, the reaction mixture became cloudy, and was stirred for $1 \mathrm{~h}$. Amide $\mathbf{1 f}$ ( $180 \mathrm{mg}, 0.50 \mathrm{mmol}, 1.0$ equiv) was added dropwise into the reaction mixture and the mixture became clear immediately. The resulting solution was moved into an ice-water bath and stirred for $30 \mathrm{~min}$. $\mathrm{ZnCl}_{2}(0.5 \mathrm{M}$ in THF, $2.0 \mathrm{~mL}, 1.0 \mathrm{mmol}$, 2.0 equiv) was added and stirred for $30 \mathrm{~min}$. The stock solution of $\left[\mathrm{Pd}(\text { allyl) } \mathrm{Cl}]_{2}(4.6 \mathrm{mg}\right.$, $0.125 \mathrm{mmol}, 0.025$ equiv) and allyl acetate ( $60 \mathrm{mg}, 0.60 \mathrm{mmol}, 1.2$ equiv) in THF ( 0.5 $\mathrm{mL}$ ) was next added at the same temperature. The reaction mixture was removed from the ice bath and stirred for $2 \mathrm{~h}$ at $23{ }^{\circ} \mathrm{C}$. The resulting mixture was stopped with addition of sat. aq. $\mathrm{NH}_{4} \mathrm{Cl}(8 \mathrm{~mL})$, diluted with EtOAc $(8 \mathrm{~mL})$, and the organic phase was separated. The aqueous phase was extracted with EtOAc $(3 \times 8 \mathrm{~mL})$ and the combined organic layers were washed with brine $(20 \mathrm{~mL})$, dried over anhydrous $\mathrm{Na}_{2} \mathrm{SO}_{4}$, filtered, and concentrated under reduced pressure by rotary evaporation. Purification by flash column chromatography on silica gel (hexanes/EtOAc $=10: 1$ to $3: 1$ ) afforded the title product as an off white soild (146 mg, 82\%). M.P.: $94-96{ }^{\circ} \mathrm{C} ; \mathbf{R}_{\mathbf{f}}=0.23$ (hexanes/EtOAc $=3: 1) ;{ }^{1} \mathbf{H}$ NMR $\left(400 \mathrm{MHz}, \mathrm{CDCl}_{3}\right): \delta 7.83(\mathrm{~d}, J=15.2 \mathrm{~Hz}, 1 \mathrm{H}), 7.43-7.22(\mathrm{~m}, 12 \mathrm{H})$, $6.86(\mathrm{~d}, J=8.4 \mathrm{~Hz}, 2 \mathrm{H}), 6.78(\mathrm{~d}, J=15.6 \mathrm{~Hz}, 1 \mathrm{H}), 4.72(\mathrm{~s}, 2 \mathrm{H}), 4.61$ (s, 2H), 3.80 (s, $3 \mathrm{H}) ;{ }^{13} \mathrm{C}$ NMR $\left(100 \mathrm{MHz}, \mathrm{CDCl}_{3}\right): \delta 167.7,161.0,143.6,137.6,137.0,129.6,129.1$, 128.7, 128.5, 128.0, 127.8, 127.5, 126.7, 114.8, 114.3, 55.4, 50.1, 48.9; IR $\left(\mathrm{cm}^{-1}\right): 2927$, 1644, 1595, 1509, 1453, 1251, 1173, 1034, 826, 707; ESI-HRMS (m/z): $[\mathrm{M}+\mathrm{H}]^{+}$calc'd $^{\prime}$ for $\mathrm{C}_{24} \mathrm{H}_{24} \mathrm{NO}_{2}$ : 358.1802 ; found: 358.1815 . 


\section{(E)-N,N-dibenzyl-3-(p-tolyl)acrylamide $2 \mathrm{~g}$}

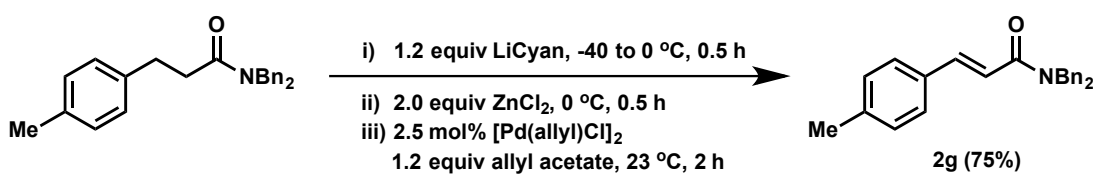

To a $-40{ }^{\circ} \mathrm{C}$ solution of $\mathrm{N}$-cyclohexyl-2,6-diisopropylaniline $(156 \mathrm{mg}, 0.60 \mathrm{mmol}$, 1.2 equiv) in THF (2.0 mL, $0.30 \mathrm{M})$ was added $n-\mathrm{BuLi}(2.5 \mathrm{M}$ in hexanes, $0.24 \mathrm{~mL}, 0.60$ mmol, 1.2 equiv). After 3-5 mins, the reaction mixture became cloudy, and was stirred for $1 \mathrm{~h}$. Amide $1 \mathrm{~g}$ ( $172 \mathrm{mg}, 0.50 \mathrm{mmol}, 1.0$ equiv) was added dropwise into the reaction mixture and the mixture became clear immediately. The resulting solution was moved into an ice-water bath and stirred for $30 \mathrm{~min}$. $\mathrm{ZnCl}_{2}(0.5 \mathrm{M}$ in THF, $2.0 \mathrm{~mL}, 1.0 \mathrm{mmol}$, 2.0 equiv) was added and stirred for $30 \mathrm{~min}$. The stock solution of $[\mathrm{Pd}(\text { allyl }) \mathrm{Cl}]_{2}(4.6 \mathrm{mg}$, $0.125 \mathrm{mmol}, 0.025$ equiv) and allyl acetate ( $60 \mathrm{mg}, 0.60 \mathrm{mmol}, 1.2$ equiv) in THF ( 0.5 $\mathrm{mL}$ ) was next added at the same temperature. The reaction mixture was removed from the ice bath and stirred for $2 \mathrm{~h}$ at $23{ }^{\circ} \mathrm{C}$. The resulting mixture was stopped with addition of sat. aq. $\mathrm{NH}_{4} \mathrm{Cl}(8 \mathrm{~mL})$, diluted with EtOAc $(8 \mathrm{~mL})$, and the organic phase was separated. The aqueous phase was extracted with EtOAc $(3 \times 8 \mathrm{~mL})$ and the combined organic layers were washed with brine $(20 \mathrm{~mL})$, dried over anhydrous $\mathrm{Na}_{2} \mathrm{SO}_{4}$, filtered, and concentrated under reduced pressure by rotary evaporation. Purification by flash column chromatography on silica gel (hexanes/EtOAc $=10: 1$ to $3: 1$ ) afforded the title product as a white soild (128 mg, 75\%). M.P.: $86-87^{\circ} \mathrm{C}$; $\mathbf{R}_{\mathbf{f}}=0.46$ (hexanes/EtOAc $=$ 3:1); ${ }^{1} \mathbf{H}$ NMR (400 MHz, $\left.\mathrm{CDCl}_{3}\right): \delta 7.88(\mathrm{~d}, J=15.6 \mathrm{~Hz}, 1 \mathrm{H}), 7.40-7.24(\mathrm{~m}, 12 \mathrm{H}), 7.16$ (d, $J=8.0 \mathrm{~Hz}, 2 \mathrm{H}), 6.90(\mathrm{~d}, J=15.2 \mathrm{~Hz}, 1 \mathrm{H}), 4.74(\mathrm{~s}, 2 \mathrm{H}), 4.63(\mathrm{~s}, 2 \mathrm{H}), 2.36(\mathrm{~s}, 3 \mathrm{H}) ;{ }^{13} \mathrm{C}$ NMR $\left(100 \mathrm{MHz}, \mathrm{CDCl}_{3}\right): \delta 167.4,143.9,140.0,137.5,136.8,132.5,129.5,129.0$, 128.6, 128.4, 127.9, 127.7, 127.4, 126.6, 116.1, 50.1, 48.8, 21.4; IR $\left(\mathrm{cm}^{-1}\right): 3029,2919$, 1641, 1593, 1477, 1445, 1202, 750; ESI-HRMS (m/z): $[\mathrm{M}+\mathrm{H}]^{+}$calc'd for $\mathrm{C}_{24} \mathrm{H}_{24} \mathrm{NO}$ : 342.1853; found: 342.1866 . 


\section{(E)-N,N-dibenzyl-3-(4-(trifluoromethyl)phenyl)acrylamide $2 \mathrm{~h}$}

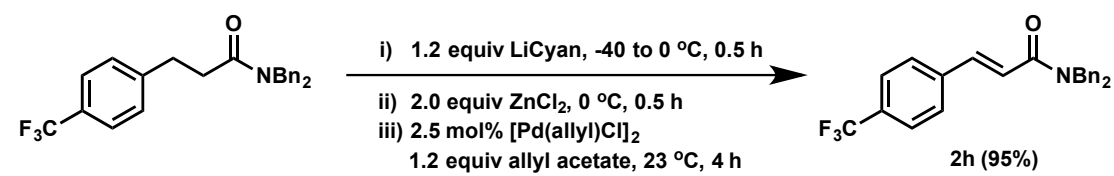

To a $-40{ }^{\circ} \mathrm{C}$ solution of $N$-cyclohexyl-2,6-diisopropylaniline $(156 \mathrm{mg}, 0.60 \mathrm{mmol}$, 1.2 equiv) in THF (2.0 mL, $0.30 \mathrm{M})$ was added $n$-BuLi (2.5 M in hexanes, $0.24 \mathrm{~mL}, 0.60$ mmol, 1.2 equiv). After 3-5 mins, the reaction mixture became cloudy, and was stirred for $1 \mathrm{~h}$. Amide $\mathbf{1 h}$ (199 mg, $0.50 \mathrm{mmol}, 1.0$ equiv) was added dropwise into the reaction mixture and the mixture became clear immediately. The resulting solution was moved into an ice-water bath and stirred for $30 \mathrm{~min}$. $\mathrm{ZnCl}_{2}(0.5 \mathrm{M}$ in THF, $2.0 \mathrm{~mL}, 1.0 \mathrm{mmol}$, 2.0 equiv) was added and stirred for $30 \mathrm{~min}$. The stock solution of $[\mathrm{Pd}(\text { allyl }) \mathrm{Cl}]_{2}(4.6 \mathrm{mg}$, $0.0125 \mathrm{mmol}, 0.025$ equiv) and allyl acetate $(60 \mathrm{mg}, 0.60 \mathrm{mmol}, 1.2$ equiv) in THF (0.5 $\mathrm{mL}$ ) was next added at the same temperature. The reaction mixture was removed from the ice bath and stirred for $4 \mathrm{~h}$ at $23{ }^{\circ} \mathrm{C}$. The resulting mixture was stopped with addition of sat. aq. $\mathrm{NH}_{4} \mathrm{Cl}(8 \mathrm{~mL})$, diluted with EtOAc $(8 \mathrm{~mL})$, and the organic phase was separated. The aqueous phase was extracted with EtOAc $(3 \times 8 \mathrm{~mL})$ and the combined organic layers were washed with brine $(20 \mathrm{~mL})$, dried over anhydrous $\mathrm{Na}_{2} \mathrm{SO}_{4}$, filtered, and concentrated under reduced pressure by rotary evaporation. Purification by flash column chromatography on silica gel (hexanes/EtOAc $=10: 1$ to $4: 1$ ) afforded the title product as an off white soild (188 mg, 95\%). M.P.: $111-112{ }^{\circ} \mathrm{C} ; \mathbf{R}_{\mathbf{f}}=0.32$ (hexanes/EtOAc $=4: 1) ;{ }^{1} \mathbf{H}$ NMR $\left(400 \mathrm{MHz}, \mathrm{CDCl}_{3}\right): \delta 7.86(\mathrm{~d}, J=15.6 \mathrm{~Hz}, 1 \mathrm{H}), 7.56$ $(\mathrm{q}, J=8.4 \mathrm{~Hz}, 4 \mathrm{H}), 7.41-7.22(\mathrm{~m}, 10 \mathrm{H}), 6.97(\mathrm{~d}, J=15.2 \mathrm{~Hz}, 1 \mathrm{H}), 4.73(\mathrm{~s}, 2 \mathrm{H}), 4.63$ (s, $2 \mathrm{H}) ;{ }^{13} \mathrm{C}$ NMR $\left(100 \mathrm{MHz}, \mathrm{CDCl}_{3}\right): \delta 166.7,142.1,138.7,137.2,136.6,131.3$ (q, $J_{C-F}=$ $32.6 \mathrm{~Hz}), 129.2,128.8,128.5,128.1,128.0,127.7,126.6,125.8$ (q, $\left.J_{C-F}=3.8 \mathrm{~Hz}\right), 124.0$ $\left(\mathrm{q}, J_{C-F}=272.2 \mathrm{~Hz}\right), 120.0,50.3,49.1 ;{ }^{19} \mathbf{F}$ NMR (400 MHz, $\left.\mathrm{CDCl}_{3}\right): \delta-62.8 ; \mathbf{I R}\left(\mathrm{cm}^{-1}\right)$ : 3028, 1648, 1603, 1494, 1443, 1321, 1207, 1123, 834, 698; ESI-HRMS (m/z): [M+H] ${ }^{+}$ calc'd for $\mathrm{C}_{24} \mathrm{H}_{21} \mathrm{~F}_{3} \mathrm{NO}$ : 396.1570; found: 396.1549 . 


\section{(E)-N,N-dibenzyl-3-(4-chlorophenyl)acrylamide $2 \mathrm{i}$}

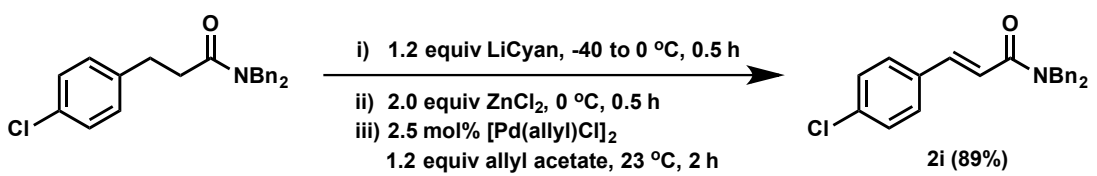

To a $-40{ }^{\circ} \mathrm{C}$ solution of $N$-cyclohexyl-2,6-diisopropylaniline $(156 \mathrm{mg}, 0.60 \mathrm{mmol}$, 1.2 equiv) in THF (2.0 mL, $0.30 \mathrm{M})$ was added $n$-BuLi (2.5 M in hexanes, $0.24 \mathrm{~mL}, 0.60$ mmol, 1.2 equiv). After 3-5 mins, the reaction mixture became cloudy, and was stirred for $1 \mathrm{~h}$. Amide $1 \mathrm{i}$ (182 $\mathrm{mg}, 0.50 \mathrm{mmol}, 1.0$ equiv) was added dropwise into the reaction mixture and the mixture became clear immediately. The resulting solution was moved into an ice-water bath and stirred for $30 \mathrm{~min}$. $\mathrm{ZnCl}_{2}(0.5 \mathrm{M}$ in THF, $2.0 \mathrm{~mL}, 1.0 \mathrm{mmol}$, 2.0 equiv) was added and stirred for $30 \mathrm{~min}$. The stock solution of $[\mathrm{Pd}(\text { allyl }) \mathrm{Cl}]_{2}(4.6 \mathrm{mg}$, $0.125 \mathrm{mmol}, 0.025$ equiv) and allyl acetate $(60 \mathrm{mg}, 0.60 \mathrm{mmol}, 1.2$ equiv) in THF (0.5 $\mathrm{mL}$ ) was next added at the same temperature. The reaction mixture was removed from the ice bath and stirred for $2 \mathrm{~h}$ at $23{ }^{\circ} \mathrm{C}$. The resulting mixture was stopped with addition of sat. aq. $\mathrm{NH}_{4} \mathrm{Cl}(8 \mathrm{~mL})$, diluted with EtOAc $(8 \mathrm{~mL})$, and the organic phase was separated. The aqueous phase was extracted with EtOAc $(3 \times 8 \mathrm{~mL})$ and the combined organic layers were washed with brine $(20 \mathrm{~mL})$, dried over anhydrous $\mathrm{Na}_{2} \mathrm{SO}_{4}$, filtered, and concentrated under reduced pressure by rotary evaporation. Purification by flash column chromatography on silica gel (hexanes/EtOAc $=10: 1$ to $4: 1$ ) afforded the title product as a white soild (162 mg, 89\%). In addition, CyanH was recovered in quantitative yield (156 mg). M.P.: $130-132{ }^{\circ} \mathrm{C} ; \mathbf{R}_{\mathbf{f}}=0.32$ (hexanes/EtOAc $\left.=4: 1\right) ;{ }^{1} \mathbf{H}$ NMR (400 $\left.\mathrm{MHz}_{\mathrm{CDCl}}\right): \delta 7.74(\mathrm{~d}, J=15.6 \mathrm{~Hz}, 1 \mathrm{H}), 7.31-7.14(\mathrm{~m}, 14 \mathrm{H}), 6.81(\mathrm{~d}, J=15.2 \mathrm{~Hz}$, 1H), 4.64 (s, 2H), 4.53 (s, 2H); ${ }^{13} \mathbf{C}$ NMR (100 MHz, $\left.\mathrm{CDCl}_{3}\right): \delta 166.9,142.4,137.3$, $136.7,135.5,133.7,129.1$ (x2), 129.0, 128.7, 128.4, 127.8, 127.5, 126.6, 117.9, 50.1, 48.9; IR ( $\left.\mathrm{cm}^{-1}\right):$ 3029, 1642, 1590, 1492, 1443, 1213, 1198, 823, 744; ESI-HRMS (m/z): $[\mathrm{M}+\mathrm{H}]^{+}$calc'd for $\mathrm{C}_{23} \mathrm{H}_{21} \mathrm{ClNO}$ : 362.1307; found: 362.1309 . 


\section{(E)- $N, N$-dibenzyl-3-(4-(trifluoromethyl)phenyl)acrylamide $2 \mathrm{j}$}

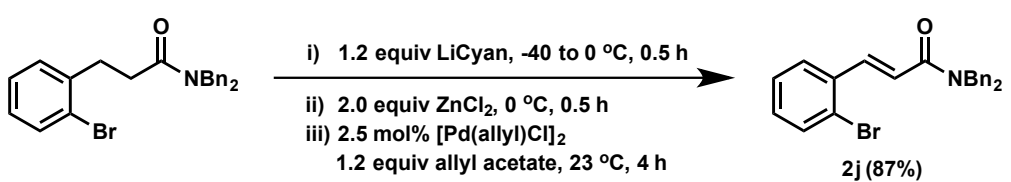

To a $-40{ }^{\circ} \mathrm{C}$ solution of $\mathrm{N}$-cyclohexyl-2,6-diisopropylaniline $(156 \mathrm{mg}, 0.60 \mathrm{mmol}$, 1.2 equiv) in THF (2.0 mL, $0.30 \mathrm{M})$ was added $n-\mathrm{BuLi}(2.5 \mathrm{M}$ in hexanes, $0.24 \mathrm{~mL}, 0.60$ mmol, 1.2 equiv). After 3-5 mins, the reaction mixture became cloudy, and was stirred for $1 \mathrm{~h}$. Amide $\mathbf{1 j}$ (204 $\mathrm{mg}, 0.50 \mathrm{mmol}, 1.0$ equiv) was added dropwise into the reaction mixture and the mixture became clear immediately. The resulting solution was moved into an ice-water bath and stirred for $30 \mathrm{~min}$. $\mathrm{ZnCl}_{2}(0.5 \mathrm{M}$ in THF, $2.0 \mathrm{~mL}, 1.0 \mathrm{mmol}$, 2.0 equiv) was added and stirred for $30 \mathrm{~min}$. The stock solution of $[\mathrm{Pd}(\text { allyl }) \mathrm{Cl}]_{2}(4.6 \mathrm{mg}$, $0.0125 \mathrm{mmol}, 0.025$ equiv) and allyl acetate $(60 \mathrm{mg}, 0.60 \mathrm{mmol}, 1.2$ equiv) in THF ( 0.5 $\mathrm{mL}$ ) was next added at the same temperature. The reaction mixture was removed from the ice bath and stirred for $4 \mathrm{~h}$ at $23{ }^{\circ} \mathrm{C}$. The resulting mixture was stopped with addition of sat. aq. $\mathrm{NH}_{4} \mathrm{Cl}(8 \mathrm{~mL})$, diluted with EtOAc $(8 \mathrm{~mL})$, and the organic phase was separated. The aqueous phase was extracted with EtOAc $(3 \times 8 \mathrm{~mL})$ and the combined organic layers were washed with brine $(20 \mathrm{~mL})$, dried over anhydrous $\mathrm{Na}_{2} \mathrm{SO}_{4}$, filtered, and concentrated under reduced pressure by rotary evaporation. Purification by flash column chromatography on silica gel (hexanes/EtOAc $=10: 1$ to $4: 1$ ) afforded the title product as a viscous oil $(177 \mathrm{mg}, 87 \%) . \mathbf{R}_{\mathbf{f}}=0.41$ (hexanes $/$ EtOAc $\left.=3: 1\right) ;{ }^{1} \mathbf{H}$ NMR $(400$ $\mathrm{MHz}, \mathrm{CDCl}_{3}$ ): $\delta 8.17(\mathrm{~d}, J=15.2 \mathrm{~Hz}, 1 \mathrm{H}), 7.58(\mathrm{dd}, J=7.6,0.8 \mathrm{~Hz}, 1 \mathrm{H}), 7.44-7.22(\mathrm{~m}$, $12 \mathrm{H}), 7.15(\mathrm{td}, J=7.6,1.2 \mathrm{~Hz}, 1 \mathrm{H}), 6.85(\mathrm{~d}, J=15.2 \mathrm{~Hz}, 1 \mathrm{H}), 4.72(\mathrm{~s}, 2 \mathrm{H}), 4.61(\mathrm{~s}, 2 \mathrm{H})$; ${ }^{13}$ C NMR $\left(100 \mathrm{MHz}, \mathrm{CDCl}_{3}\right): \delta 166.7,142.2,137.3,136.7,135.5,133.4,130.7,129.1$, 128.7, 128.5, 127.9, 127.6, 126.6, 125.2, 120.6, 50.2, 48.9; IR $\left(\mathrm{cm}^{-1}\right): 3029,2927,1645$, 1603, 1494, 1418, 1359, 1261, 1201, 1026, 752, 696; ESI-HRMS (m/z): $[\mathrm{M}+\mathrm{H}]^{+}$calc'd $^{\prime}$ for $\mathrm{C}_{23} \mathrm{H}_{21}{ }^{8 I} \mathrm{BrNO}$ : 408.0781; found: 408.0781 . 


\section{(E)-N,N-diethylhex-2-en-4-ynamide $2 \mathrm{k}$}

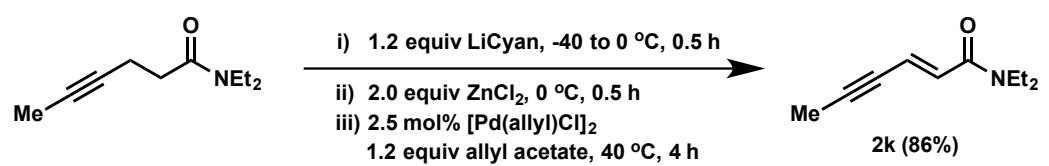

To a $-40{ }^{\circ} \mathrm{C}$ solution of $\mathrm{N}$-cyclohexyl-2,6-diisopropylaniline $(78 \mathrm{mg}, 0.3 \mathrm{mmol}$, 1.2 equiv) in THF (2.0 mL, $0.15 \mathrm{M})$ was added $n-\mathrm{BuLi}(2.5 \mathrm{M}$ in hexanes, $0.12 \mathrm{~mL}, 0.30$ mmol, 1.2 equiv). After 3-5 mins, the reaction mixture became cloudy, and was stirred for $1 \mathrm{~h}$. Amide $1 \mathbf{k}$ ( $42 \mathrm{mg}, 0.25 \mathrm{mmol}, 1.0$ equiv) was added dropwise into the reaction mixture and the mixture became clear immediately. The resulting solution was moved into an ice-water bath and stirred for $30 \mathrm{~min}$. $\mathrm{ZnCl}_{2}(0.5 \mathrm{M}$ in THF, $1.0 \mathrm{~mL}, 0.5 \mathrm{mmol}$, 2.0 equiv) was added and stirred for $30 \mathrm{~min}$. The stock solution of $[\mathrm{Pd}(\text { allyl }) \mathrm{Cl}]_{2}(2.3 \mathrm{mg}$, $0.0063 \mathrm{mmol}, 0.025$ equiv) and allyl acetate ( $30 \mathrm{mg}, 0.30 \mathrm{mmol}, 1.2$ equiv) in THF ( 0.25 $\mathrm{mL}$ ) was next added at the same temperature. The reaction mixture was placed into a preheated $40{ }^{\circ} \mathrm{C}$ oil bath and stirred for $4 \mathrm{~h}$. The resulting mixture was cooled to room temperature and stopped with the addition of sat. aq. $\mathrm{NH}_{4} \mathrm{Cl}(8 \mathrm{~mL})$, diluted with EtOAc $(8 \mathrm{~mL})$, and the organic phase was separated. The aqueous phase was extracted with EtOAc $(3 \times 8 \mathrm{~mL})$ and the combined organic layers were washed with brine $(20 \mathrm{~mL})$, dried over anhydrous $\mathrm{Na}_{2} \mathrm{SO}_{4}$, filtered, and concentrated under reduced pressure by rotary evaporation. Purification by flash column chromatography on silica gel (hexanes/Et $2 \mathrm{O}=$ $1: 1$ to 1:2) afforded the title product as a colorless oil (35 $\mathrm{mg}, 86 \%) . \mathbf{R}_{\mathbf{f}}=0.35$ (hexanes/ $\left.\mathrm{Et}_{2} \mathrm{O}=1: 2\right) ;{ }^{1} \mathbf{H}$ NMR $\left(400 \mathrm{MHz}, \mathrm{CDCl}_{3}\right): \delta 6.72(\mathrm{dd}, J=15.2,2.4 \mathrm{~Hz}, 1 \mathrm{H})$, 6.58 (d, $J=15.2 \mathrm{~Hz}, 1 \mathrm{H}), 3.41$ (q, $J=7.2 \mathrm{~Hz}, 2 \mathrm{H}), 3.34$ (q, $J=7.2 \mathrm{~Hz}, 2 \mathrm{H}), 1.99$ (s, 3H), $1.17(\mathrm{t}, J=7.2 \mathrm{~Hz}, 3 \mathrm{H}), 1.12(\mathrm{t}, J=7.2 \mathrm{~Hz}, 3 \mathrm{H}) ;{ }^{13} \mathbf{C} \mathbf{N M R}\left(100 \mathrm{MHz}, \mathrm{CDCl}_{3}\right): \delta 164.8$, 128.8, 123.6, 93.9, 78.0, 42.2, 41.1, 15.1, 13.2, 4.8; IR $\left(\mathrm{cm}^{-1}\right): 2972,2934,1634,1597$, 1430, 1284, 1218, 1132, 955, 850, 789; ESI-HRMS (m/z): $[\mathrm{M}+\mathrm{H}]^{+}$calc'd for $\mathrm{C}_{10} \mathrm{H}_{16} \mathrm{NO}$ : 166.1189; found: 166.1219 . 
Amide 2l

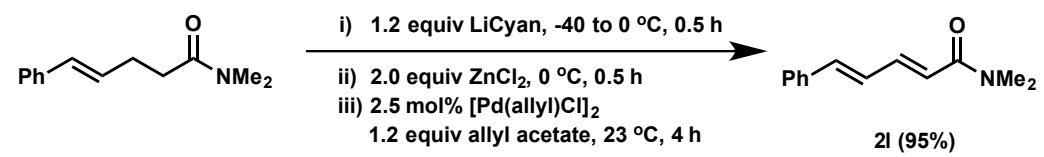

To a $-40{ }^{\circ} \mathrm{C}$ solution of $\mathrm{N}$-cyclohexyl-2,6-diisopropylaniline $(156 \mathrm{mg}, 0.60 \mathrm{mmol}$, 1.2 equiv) in THF (2.0 mL, $0.30 \mathrm{M})$ was added $n-\mathrm{BuLi}(2.5 \mathrm{M}$ in hexanes, $0.24 \mathrm{~mL}, 0.60$ mmol, 1.2 equiv). After 3-5 mins, the reaction mixture became cloudy, and was stirred for $1 \mathrm{~h}$. Amide $1 \mathrm{l}$ (102 $\mathrm{mg}, 0.50 \mathrm{mmol}, 1.0$ equiv) was added dropwise into the reaction mixture and the mixture became clear immediately. The resulting solution was moved into an ice-water bath and stirred for $30 \mathrm{~min}$. $\mathrm{ZnCl}_{2}(0.5 \mathrm{M}$ in THF, $2.0 \mathrm{~mL}, 1.0 \mathrm{mmol}$, 2.0 equiv) was added and stirred for $30 \mathrm{~min}$. The stock solution of $[\mathrm{Pd}(\text { allyl }) \mathrm{Cl}]_{2}(4.6 \mathrm{mg}$, $0.0125 \mathrm{mmol}, 0.025$ equiv) and allyl acetate $(60 \mathrm{mg}, 0.60 \mathrm{mmol}, 1.2$ equiv) in THF ( 0.5 $\mathrm{mL}$ ) was next added at the same temperature. The reaction mixture was removed from the ice bath and stirred for $4 \mathrm{~h}$ at $23{ }^{\circ} \mathrm{C}$. The resulting mixture was stopped with addition of sat. aq. $\mathrm{NH}_{4} \mathrm{Cl}(8 \mathrm{~mL})$, diluted with EtOAc $(8 \mathrm{~mL})$, and the organic phase was separated. The aqueous phase was extracted with EtOAc $(3 \times 8 \mathrm{~mL})$ and the combined organic layers were washed with brine $(20 \mathrm{~mL})$, dried over anhydrous $\mathrm{Na}_{2} \mathrm{SO}_{4}$, filtered, and concentrated under reduced pressure by rotary evaporation. Purification by flash column chromatography on silica gel (hexanes/EtOAc $=3: 1$ to $0: 1$ ) afforded the title product as an off white foam (96 mg, 95\%). $\mathbf{R}_{\mathbf{f}}=0.35$ (EtOAc); ${ }^{1} \mathbf{H}$ NMR $(400 \mathrm{MHz}$, $\mathrm{CDCl}_{3}$ ): $\delta 7.42-7.36(\mathrm{~m}, 3 \mathrm{H}), 7.27(\mathrm{t}, J=7.6 \mathrm{~Hz}, 2 \mathrm{H}), 7.21(\mathrm{t}, J=7.2 \mathrm{~Hz}, 1 \mathrm{H}), 6.89-6.76$ $(\mathrm{m}, 2 \mathrm{H}), 6.40(\mathrm{~d}, J=14.8 \mathrm{~Hz}, 1 \mathrm{H}), 3.02(\mathrm{~s}, 3 \mathrm{H}), 2.96(\mathrm{~s}, 3 \mathrm{H}) ;{ }^{13} \mathbf{C}$ NMR $(100 \mathrm{MHz}$, $\left.\mathrm{CDCl}_{3}\right): \delta 166.5,142.2,138.7,136.3,128.6,128.5,126.9,126.8,120.7,37.2,35.7$; IR ( $\left.\mathrm{cm}^{-1}\right): 2932,2189,2159,1982,1641,1599,1487,1396,1123,1019,757$; ESI-HRMS $(\mathrm{m} / \mathrm{z}):[\mathrm{M}+\mathrm{H}]^{+}$calc'd for $\mathrm{C}_{13} \mathrm{H}_{16} \mathrm{NO}: 202.1227$; found: 202.1212 . 


\section{1-(4-methoxybenzyl)-1,5-dihydro-2H-pyrrol-2-one $2 \mathrm{~m}$}

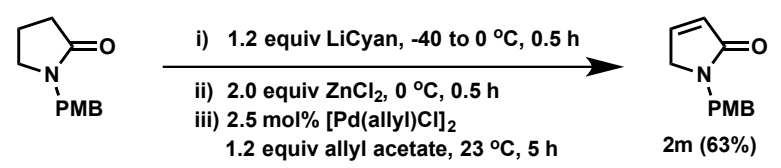

To a $-40{ }^{\circ} \mathrm{C}$ solution of $N$-cyclohexyl-2,6-diisopropylaniline (156 $\mathrm{mg}, 0.60 \mathrm{mmol}$, 1.2 equiv) in THF (2.0 mL, $0.30 \mathrm{M})$ was added $n$-BuLi (2.5 M in hexanes, $0.24 \mathrm{~mL}, 0.60$ mmol, 1.2 equiv). After 3-5 mins, the reaction mixture became cloudy, and was stirred for $1 \mathrm{~h}$. Lactam $1 \mathrm{~m}$ (103 $\mathrm{mg}, 0.50 \mathrm{mmol}, 1.0$ equiv) was added dropwise into the reaction mixture and the mixture became clear immediately. The resulting solution was moved into an ice-water bath and stirred for $30 \mathrm{~min}$. $\mathrm{ZnCl}_{2}(0.5 \mathrm{M}$ in THF, $2.0 \mathrm{~mL}, 1.0 \mathrm{mmol}$, 2.0 equiv) was added and stirred for $30 \mathrm{~min}$. The stock solution of $\left[\mathrm{Pd}(\text { allyl }) \mathrm{Cl}_{2}\right]_{2}(4.6 \mathrm{mg}$, $0.0125 \mathrm{mmol}, 0.025$ equiv) and allyl acetate $(60 \mathrm{mg}, 0.60 \mathrm{mmol}, 1.2$ equiv) in THF (0.5 $\mathrm{mL}$ ) was next added at the same temperature. The reaction mixture was removed from the ice bath and stirred for $5 \mathrm{~h}$ at $23{ }^{\circ} \mathrm{C}$. The resulting mixture was stopped with addition of sat. aq. $\mathrm{NH}_{4} \mathrm{Cl}(8 \mathrm{~mL})$, diluted with EtOAc $(8 \mathrm{~mL})$, and the organic phase was separated. The aqueous phase was extracted with EtOAc $(3 \times 8 \mathrm{~mL})$ and the combined organic layers were washed with brine $(20 \mathrm{~mL})$, dried over anhydrous $\mathrm{Na}_{2} \mathrm{SO}_{4}$, filtered, and concentrated under reduced pressure by rotary evaporation. Purification by flash column chromatography on silica gel (hexanes/EtOAc $=3: 1$ to $0: 1$ ) afforded the title product as a yellow solid (64 mg, 63\%). M.P.: 85-88 ${ }^{\circ} \mathrm{C} ; \mathbf{R}_{\mathbf{f}}=0.35$ (EtOAc); ${ }^{1} \mathbf{H}$ NMR (400 MHz, $\left.\mathrm{CDCl}_{3}\right): \delta 7.15(\mathrm{~d}, J=8.4 \mathrm{~Hz}, 2 \mathrm{H}), 7.01$ (adt, $\left.J=6.0,2.0 \mathrm{~Hz}, 1 \mathrm{H}\right), 6.83(\mathrm{~d}, J$ $=8.4 \mathrm{~Hz}, 2 \mathrm{H}), 6.19-6.17(\mathrm{~m}, 1 \mathrm{H}), 4.55(\mathrm{~s}, 2 \mathrm{H}), 3.83(\mathrm{~s}, 2 \mathrm{H}), 3.78(\mathrm{~s}, 3 \mathrm{H}) ;{ }^{13} \mathbf{C}$ NMR (100 $\left.\mathrm{MHz}, \mathrm{CDCl}_{3}\right): \delta 171.3,159.1,142.9,129.5,129.4,128.1,114.2,55.3,52.2,45.4 ; \mathbf{I R}\left(\mathrm{cm}^{-}\right.$ $\left.{ }^{1}\right): 3074,1663,1610,1510,1451,1241,1174,1121,1028,853,814$; The spectral data are consistent with those reported in the literature. ${ }^{19}$ 


\section{1-Allyl-5,6-dihydropyridin-2(1H)-one 2n}

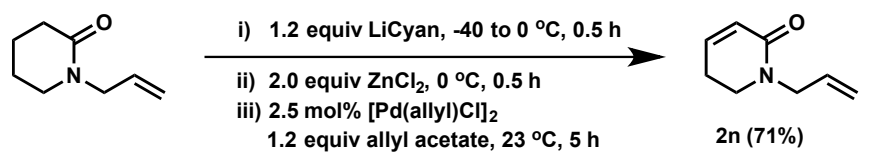

To a $-40{ }^{\circ} \mathrm{C}$ solution of $\mathrm{N}$-cyclohexyl-2,6-diisopropylaniline $(156 \mathrm{mg}, 0.60 \mathrm{mmol}$, 1.2 equiv) in THF (2.0 mL, $0.30 \mathrm{M})$ was added $n-\mathrm{BuLi}(2.5 \mathrm{M}$ in hexanes, $0.24 \mathrm{~mL}, 0.60$ mmol, 1.2 equiv). After 3-5 mins, the reaction mixture became cloudy, and was stirred for $1 \mathrm{~h}$. Lactam $1 \mathrm{n}$ ( $70 \mathrm{mg}, 0.50 \mathrm{mmol}, 1.0$ equiv) was added dropwise into the reaction mixture and the mixture became clear immediately. The resulting solution was moved into an ice-water bath and stirred for $30 \mathrm{~min}$. $\mathrm{ZnCl}_{2}(0.5 \mathrm{M}$ in THF, $2.0 \mathrm{~mL}, 1.0 \mathrm{mmol}$, 2.0 equiv) was added and stirred for $30 \mathrm{~min}$. The stock solution of $[\mathrm{Pd}(\text { allyl }) \mathrm{Cl}]_{2}(4.6 \mathrm{mg}$, $0.0125 \mathrm{mmol}, 0.025$ equiv) and allyl acetate $(60 \mathrm{mg}, 0.60 \mathrm{mmol}, 1.2$ equiv) in THF ( 0.5 $\mathrm{mL}$ ) was next added at the same temperature. The reaction mixture was removed from the ice bath and stirred for $5 \mathrm{~h}$ at $23{ }^{\circ} \mathrm{C}$. The resulting mixture was stopped with addition of sat. aq. $\mathrm{NH}_{4} \mathrm{Cl}(8 \mathrm{~mL})$, diluted with EtOAc $(8 \mathrm{~mL})$, and the organic phase was separated. The aqueous phase was extracted with EtOAc $(3 \times 8 \mathrm{~mL})$ and the combined organic layers were washed with brine $(20 \mathrm{~mL})$, dried over anhydrous $\mathrm{Na}_{2} \mathrm{SO}_{4}$, filtered, and concentrated under reduced pressure by rotary evaporation. Purification by flash column chromatography on silica gel (hexanes/EtOAc $=3: 1$ to $0: 1$ ) afforded the title product as a colorless oil (48 $\mathrm{mg}, 71 \%$ ). In addition, CyanH was recovered in 95\% yield $(148 \mathrm{mg}) . \mathbf{R}_{\mathbf{f}}=0.41$ (EtOAc); ${ }^{1} \mathbf{H}$ NMR $\left(400 \mathrm{MHz}, \mathrm{CDCl}_{3}\right): \delta 6.52(\mathrm{dt}, J=10.0,4.0 \mathrm{~Hz}$, 1H), 5.92 (adt, $J=10.0,2.0 \mathrm{~Hz}, 1 \mathrm{H}$ ), 5.75 (ddt, $J=17.2,10.2,6.0 \mathrm{~Hz}, 1 \mathrm{H}$ ), $5.18-5.13$ $(\mathrm{m}, 2 \mathrm{H}), 4.00(\mathrm{~d}, J=6.0 \mathrm{~Hz}, 2 \mathrm{H}), 3.33(\mathrm{t}, J=7.2 \mathrm{~Hz}, 2 \mathrm{H}), 2.35-2.31(\mathrm{~m}, 2 \mathrm{H}) ;{ }^{13} \mathbf{C} \mathbf{N M R}$ $\left(100 \mathrm{MHz}, \mathrm{CDCl}_{3}\right): \delta 164.3,139.5,133.2,125.5,117.4,48.8,44.6,24.2 ; \mathbf{I R}\left(\mathrm{cm}^{-1}\right): 3074$, 1660, 1608, 1584, 1512, 1482, 1242, 1174, 1026, 815, 802, 758; ESI-HRMS (m/z): $[\mathrm{M}+\mathrm{H}]^{+}$calc'd for $\mathrm{C}_{8} \mathrm{H}_{12} \mathrm{NO}$ : 138.0913; found: 138.0885 . 


\section{1-Methyl-1,5,6,7-tetrahydro-2H-azepin-2-one 20}

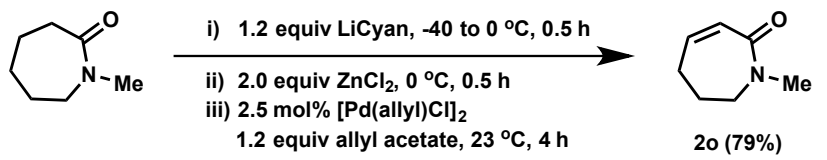

To a $-40{ }^{\circ} \mathrm{C}$ solution of $N$-cyclohexyl-2,6-diisopropylaniline $(156 \mathrm{mg}, 0.60 \mathrm{mmol}$, 1.2 equiv) in THF (2.0 mL, $0.30 \mathrm{M})$ was added $n$-BuLi (2.5 M in hexanes, $0.24 \mathrm{~mL}, 0.60$ mmol, 1.2 equiv). After $3-5$ mins, the reaction mixture became cloudy, and was stirred for $1 \mathrm{~h}$. Lactam $1 \mathrm{o}(67 \mathrm{mg}, 0.50 \mathrm{mmol}, 1.0$ equiv) was added dropwise into the reaction mixture and the mixture became clear immediately. The resulting solution was moved into an ice-water bath and stirred for $30 \mathrm{~min}$. $\mathrm{ZnCl}_{2}(0.5 \mathrm{M}$ in THF, $2.0 \mathrm{~mL}, 1.0 \mathrm{mmol}$, 2.0 equiv) was added and stirred for $30 \mathrm{~min}$. The stock solution of $[\mathrm{Pd}(\text { allyl }) \mathrm{Cl}]_{2}(4.6 \mathrm{mg}$, $0.0125 \mathrm{mmol}, 0.025$ equiv) and allyl acetate $(60 \mathrm{mg}, 0.60 \mathrm{mmol}, 1.2$ equiv) in THF (0.5 $\mathrm{mL}$ ) was next added at the same temperature. The reaction mixture was removed from the ice bath and stirred for $4 \mathrm{~h}$ at $23{ }^{\circ} \mathrm{C}$. The resulting mixture was stopped with addition of sat. aq. $\mathrm{NH}_{4} \mathrm{Cl}(8 \mathrm{~mL})$, diluted with EtOAc $(8 \mathrm{~mL})$, and the organic phase was separated. The aqueous phase was extracted with EtOAc $(3 \times 8 \mathrm{~mL})$ and the combined organic layers were washed with brine $(20 \mathrm{~mL})$, dried over anhydrous $\mathrm{Na}_{2} \mathrm{SO}_{4}$, filtered, and concentrated under reduced pressure by rotary evaporation. Purification by flash column chromatography on silica gel (hexanes/EtOAc/MeOH $=4: 1: 0$ to $0: 8: 1$ ) afforded the title product as a colorless oil $(50 \mathrm{mg}, 79 \%) . \mathbf{R}_{\mathbf{f}}=0.58(\mathrm{DCM} / \mathrm{MeOH}=7: 1) ;{ }^{1} \mathbf{H}$ NMR (400 MHz, $\left.\mathrm{CDCl}_{3}\right): \delta 6.13(\mathrm{dt}, J=12.0,5.2 \mathrm{~Hz}, 1 \mathrm{H}), 5.92(\mathrm{adt}, J=12.0,1.6 \mathrm{~Hz}$, $1 \mathrm{H}), 3.31$ (quint, $J=2.8 \mathrm{~Hz}, 2 \mathrm{H}), 3.00(\mathrm{~s}, 3 \mathrm{H}), 2.30-2.24(\mathrm{~m}, 2 \mathrm{H}), 1.94-1.89(\mathrm{~m}, 2 \mathrm{H})$; ${ }^{13}$ C NMR (100 MHz, $\left.\mathrm{CDCl}_{3}\right): \delta 168.6,137.9,126.7,49.2,35.8,28.2,27.7 ; \mathbf{I R}\left(\mathrm{cm}^{-1}\right)$ : 2927, 1648, 1592, 1491，1438，1398，1263，1229，1122，833，818，798; ESI-HRMS $(\mathrm{m} / \mathrm{z}):[\mathrm{M}+\mathrm{H}]^{+}$calc'd for $\mathrm{C}_{7} \mathrm{H}_{11} \mathrm{NONa}$ : 148.0733; found: 148.0719 . 


\section{(Z)-1-Benzyl-5,6,7,8-tetrahydroazocin-2(1H)-one 2p}

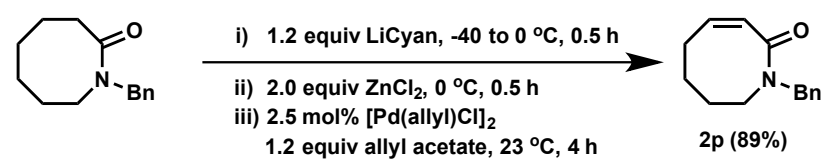

To a $-40{ }^{\circ} \mathrm{C}$ solution of $\mathrm{N}$-cyclohexyl-2,6-diisopropylaniline $(156 \mathrm{mg}, 0.60 \mathrm{mmol}$, 1.2 equiv) in THF (2.0 mL, $0.30 \mathrm{M})$ was added $n-\mathrm{BuLi}(2.5 \mathrm{M}$ in hexanes, $0.24 \mathrm{~mL}, 0.60$ mmol, 1.2 equiv). After 3-5 mins, the reaction mixture became cloudy, and was stirred for $1 \mathrm{~h}$. Lactam $1 \mathbf{p}$ (109 $\mathrm{mg}, 0.50 \mathrm{mmol}, 1.0$ equiv) was added dropwise into the reaction mixture and the mixture became clear immediately. The resulting solution was moved into an ice-water bath and stirred for $30 \mathrm{~min}$. $\mathrm{ZnCl}_{2}(0.5 \mathrm{M}$ in THF, $2.0 \mathrm{~mL}, 1.0 \mathrm{mmol}$, 2.0 equiv) was added and stirred for $30 \mathrm{~min}$. The stock solution of $[\mathrm{Pd}(\text { allyl }) \mathrm{Cl}]_{2}(4.6 \mathrm{mg}$, $0.0125 \mathrm{mmol}, 0.025$ equiv) and allyl acetate $(60 \mathrm{mg}, 0.60 \mathrm{mmol}, 1.2$ equiv) in THF ( 0.5 $\mathrm{mL}$ ) was next added at the same temperature. The reaction mixture was removed from the ice bath and stirred for $4 \mathrm{~h}$ at $23{ }^{\circ} \mathrm{C}$. The resulting mixture was stopped with addition of sat. aq. $\mathrm{NH}_{4} \mathrm{Cl}(8 \mathrm{~mL})$, diluted with EtOAc $(8 \mathrm{~mL})$, and the organic phase was separated. The aqueous phase was extracted with EtOAc $(3 \times 8 \mathrm{~mL})$ and the combined organic layers were washed with brine $(20 \mathrm{~mL})$, dried over anhydrous $\mathrm{Na}_{2} \mathrm{SO}_{4}$, filtered, and concentrated under reduced pressure by rotary evaporation. Purification by flash column chromatography on silica gel (hexanes/EtOAc $=8: 1$ to $1: 1$ ) afforded the title product as an off white solid ( $96 \mathrm{mg}, 89 \%$ ). In addition, $\mathrm{CyanH}$ was recovered in $98 \%$ yield $(153 \mathrm{mg}) . \mathbf{R}_{\mathbf{f}}=0.29$ (hexanes/EtOAc $\left.=1: 1\right) ;{ }^{1} \mathbf{H} \mathbf{~ N M R}\left(400 \mathrm{MHz}, \mathrm{CDCl}_{3}\right): \delta 7.30$ 7.21 (m, 5H), 5.97 (dt, $J=12.4,5.2 \mathrm{~Hz}, 1 \mathrm{H}$ ), 5.81 (adt, $J=12.4,1.6 \mathrm{~Hz}, 1 \mathrm{H}$ ), 4.63 (bs, 2H), 3.68-3.18 (m, 2H), 2.39-2.01 (m, 2H), 1.76-1.43 (m, 4H); ${ }^{13} \mathbf{C}$ NMR (100 MHz, $\left.\mathrm{CDCl}_{3}\right): \delta 169.4,137.4,137.3,128.5,128.3,127.4,122.3,47.6,45.9,30.4,26.7,20.3 ; \mathbf{I R}$ $\left(\mathrm{cm}^{-1}\right):$ 2930, 1648, 1601, 1495, 1472, 1428, 1294, 1194, 1073, 944, 703; ESI-HRMS $(\mathrm{m} / \mathrm{z}):[\mathrm{M}+\mathrm{H}]^{+}$calc'd for $\mathrm{C}_{14} \mathrm{H}_{18} \mathrm{NO}: 216.1383$; found: 216.1395 . 


\section{2,3,8,8a-Tetrahydroindolizin-5(1H)-one $2 q$}

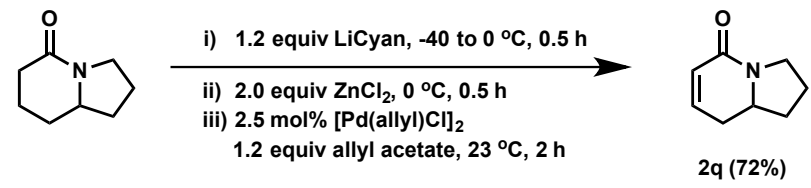

To a $-40{ }^{\circ} \mathrm{C}$ solution of $\mathrm{N}$-cyclohexyl-2,6-diisopropylaniline $(78 \mathrm{mg}, 0.30 \mathrm{mmol}$, 1.2 equiv) in THF (2.0 mL, $0.15 \mathrm{M})$ was added $n$-BuLi (2.5 M in hexanes, $0.12 \mathrm{~mL}, 0.30$ mmol, 1.2 equiv). After 3-5 mins, the reaction mixture became cloudy, and was stirred for $1 \mathrm{~h}$. Lactam 1q (35 mg, $0.25 \mathrm{mmol}, 1.0$ equiv) was added dropwise into the reaction mixture and the mixture became clear immediately. The resulting solution was moved into an ice-water bath and stirred for $30 \mathrm{~min}$. $\mathrm{ZnCl}_{2}(0.5 \mathrm{M}$ in THF, $1.0 \mathrm{~mL}, 0.5 \mathrm{mmol}$, 2.0 equiv) was added and stirred for $30 \mathrm{~min}$. The stock solution of $\left[\mathrm{Pd}(\right.$ allyl $) \mathrm{Cl}_{2}(2.3 \mathrm{mg}$, $0.0063 \mathrm{mmol}, 0.025$ equiv) and allyl acetate $(30 \mathrm{mg}, 0.30 \mathrm{mmol}, 1.2$ equiv) in THF (0.25 $\mathrm{mL}$ ) was next added at the same temperature. The reaction mixture was removed from the ice bath and stirred for $2 \mathrm{~h}$ at $23{ }^{\circ} \mathrm{C}$. The resulting mixture was stopped with addition of sat. aq. $\mathrm{NH}_{4} \mathrm{Cl}(8 \mathrm{~mL})$, diluted with EtOAc $(8 \mathrm{~mL})$, and the organic phase was separated. The aqueous phase was extracted with EtOAc $(3 \times 8 \mathrm{~mL})$ and the combined organic layers were washed with brine $(20 \mathrm{~mL})$, dried over anhydrous $\mathrm{Na}_{2} \mathrm{SO}_{4}$, filtered, and concentrated under reduced pressure by rotary evaporation. Purification by flash column chromatography on silica gel (EtOAc/MeOH $=1: 0$ to $10: 1)$ afforded the title product as a colorless oil (25 mg, 72\%). $\mathbf{R}_{\mathbf{f}}=0.27(\mathrm{EtOAc} / \mathrm{MeOH}=10: 1) ;{ }^{1} \mathbf{H}$ NMR (400 $\mathrm{MHz}, \mathrm{CDCl}_{3}$ ): $\delta 6.48$ (ddd, $\left.J=10.0,5.6,2.0 \mathrm{~Hz}, 1 \mathrm{H}\right), 5.93$ (adt, $J=10.0,3.2 \mathrm{~Hz}, 1 \mathrm{H}$ ), 3.72-3.60 (m, 2H), 3.49-3.42 (m, 1H), $2.46(\mathrm{dt}, J=17.2,5.6 \mathrm{~Hz}, 1 \mathrm{H}), 2.23-1.97(\mathrm{~m}$, $3 \mathrm{H}), 1.83-1.71(\mathrm{~m}, 1 \mathrm{H}), 1.66-1.55(\mathrm{~m}, 1 \mathrm{H}) ;{ }^{13} \mathrm{C}$ NMR $\left(100 \mathrm{MHz}, \mathrm{CDCl}_{3}\right): \delta 163.6$, 138.2, 126.1, 56.6, 44.1, 33.6, 30.5, 22.9; IR $\left(\mathrm{cm}^{-1}\right): 2948,2878,1649,1596,1447,815$; ESI-HRMS (m/z): $[\mathrm{M}+\mathrm{H}]^{+}$calc'd for $\mathrm{C}_{8} \mathrm{H}_{12} \mathrm{NO}$ : 138.0913; found: 138.0906 . 


\section{2-Benzyl-1,2,7,8,9,9a-hexahydro-5H-pyrrolo[1,2-a][1,4]diazepin-5-one $2 \mathrm{r}$}
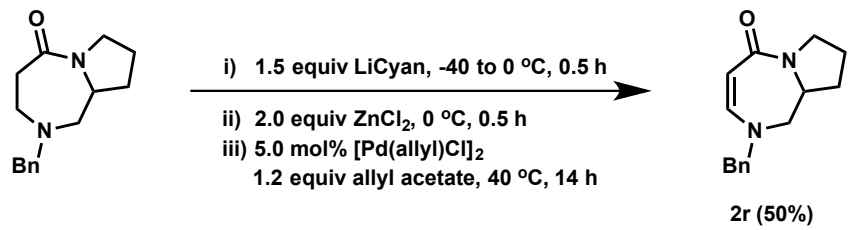

To a $-40{ }^{\circ} \mathrm{C}$ solution of $\mathrm{N}$-cyclohexyl-2,6-diisopropylaniline $(78 \mathrm{mg}, 0.30 \mathrm{mmol}$, 1.5 equiv) in THF (2.0 mL, $0.15 \mathrm{M})$ was added $n-\operatorname{BuLi~}(2.5 \mathrm{M}$ in hexanes, $0.12 \mathrm{~mL}, 0.30$ mmol, 1.5 equiv). After 3-5 mins, the reaction mixture became cloudy, and was stirred for $1 \mathrm{~h}$. Lactam $1 \mathbf{r}$ ( $49 \mathrm{mg}, 0.20 \mathrm{mmol}, 1.0$ equiv) was added dropwise into the reaction mixture and the mixture became clear immediately. The resulting solution was moved into an ice-water bath and stirred for $30 \mathrm{~min}$. $\mathrm{ZnCl}_{2}(0.5 \mathrm{M}$ in THF, $0.8 \mathrm{~mL}, 0.4 \mathrm{mmol}$, 2.0 equiv) was added and stirred for $30 \mathrm{~min}$. The stock solution of $[\mathrm{Pd}(\text { allyl }) \mathrm{Cl}]_{2}(3.9 \mathrm{mg}$, $0.01 \mathrm{mmol}, 0.05$ equiv) and allyl acetate ( $24 \mathrm{mg}, 0.24 \mathrm{mmol}, 1.2$ equiv) in THF ( 0.20 $\mathrm{mL}$ ) was next added at the same temperature. The reaction mixture was placed into a preheated $40{ }^{\circ} \mathrm{C}$ oil bath and stirred for $14 \mathrm{~h}$. The resulting mixture was cooled to room temperature and stopped with the addition of sat. aq. $\mathrm{NH}_{4} \mathrm{Cl}(8 \mathrm{~mL})$, diluted with EtOAc $(8 \mathrm{~mL})$, and the organic phase was separated. The aqueous phase was extracted with EtOAc $(3 \times 8 \mathrm{~mL})$ and the combined organic layers were washed with brine $(20 \mathrm{~mL})$, dried over anhydrous $\mathrm{Na}_{2} \mathrm{SO}_{4}$, filtered, and concentrated under reduced pressure by rotary evaporation. Purification by flash column chromatography on silica gel (hexanes/acetone $=1: 1$ to $0: 1$, then $\mathrm{MeOH} / \mathrm{EtOAc}=10: 1)$ afforded the title product as a yellow solid $(24$ mg, 50\%). M.P.: $102-104{ }^{\circ} \mathrm{C} ; \mathbf{R}_{\mathbf{f}}=0.27$ (acetone); ${ }^{1} \mathbf{H}$ NMR (400 MHz, $\mathrm{CDCl}_{3}$ ): $\delta 7.37-$ 7.28 (m, 3H), 7.19 (d, $J=6.8 \mathrm{~Hz}, 2 \mathrm{H}), 6.41$ (d, $J=10.0 \mathrm{~Hz}, 1 \mathrm{H}), 4.64$ (d, $J=10.0 \mathrm{~Hz}$, $1 \mathrm{H}), 4.28(\mathrm{ABq}, J=15.6 \mathrm{~Hz}, 2 \mathrm{H}), 3.78(\mathrm{ddd}, J=12.0,9.6,2.4 \mathrm{~Hz}, 1 \mathrm{H}), 3.67$ (q, $J=7.2$ Hz, 1H), 3.36 (ddd, $J=12.0,10.0,7.2 \mathrm{~Hz}, 1 \mathrm{H}$ ), 3.26 (d, $J=13.6 \mathrm{~Hz}, 1 \mathrm{H}), 3.11$ (dd, $J=$ 13.6, 7.2 Hz, 1H), 2.15-2.08 (m, 1H), 1.85-1.68 (m, 2H), 1.56-1.48 (m, 1H); ${ }^{13} \mathbf{C}$ NMR $\left(100 \mathrm{MHz}, \mathrm{CDCl}_{3}\right): \delta 167.3,143.4,136.8,129.0,128.1,127.4,91.9,61.7,56.9,56.8$, 47.5, 31.8, 23.3; IR ( $\left.\mathrm{cm}^{-1}\right): 3153,2931,1659,1606,1592,1454,1441,1420,1309,1241$, 1121, 811, 709; ESI-HRMS (m/z): $[\mathrm{M}+\mathrm{H}]^{+}$calc'd for $\mathrm{C}_{15} \mathrm{H}_{19} \mathrm{~N}_{2} \mathrm{O}: 243.1492$; found: 243.1469 . 


\section{7-Methoxy-1-methylquinolin-2(1H)-one $2 \mathrm{~s}$}

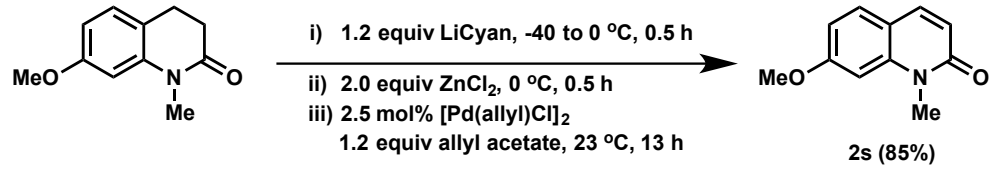

To a $-40{ }^{\circ} \mathrm{C}$ solution of $N$-cyclohexyl-2,6-diisopropylaniline $(78 \mathrm{mg}, 0.30 \mathrm{mmol}$, 1.2 equiv) in THF (2.0 mL, $0.15 \mathrm{M})$ was added $n$-BuLi (2.5 M in hexanes, $0.12 \mathrm{~mL}, 0.30$ mmol, 1.2 equiv). After $3-5$ mins, the reaction mixture became cloudy, and was stirred for $1 \mathrm{~h}$. Lactam $1 \mathrm{~s}$ (48 $\mathrm{mg}, 0.25 \mathrm{mmol}, 1.0$ equiv) was added dropwise into the reaction mixture and the mixture became clear immediately. The resulting solution was moved into an ice-water bath and stirred for $30 \mathrm{~min}$. $\mathrm{ZnCl}_{2}(0.5 \mathrm{M}$ in THF, $1.0 \mathrm{~mL}, 0.5 \mathrm{mmol}$, 2.0 equiv) was added and stirred for $30 \mathrm{~min}$. The stock solution of $[\mathrm{Pd}(\text { allyl }) \mathrm{Cl}]_{2}(2.3 \mathrm{mg}$, $0.0063 \mathrm{mmol}, 0.025$ equiv) and allyl acetate $(30 \mathrm{mg}, 0.30 \mathrm{mmol}, 1.2$ equiv) in THF (0.25 $\mathrm{mL}$ ) was next added at the same temperature. The reaction mixture was removed from the ice bath and stirred for $4 \mathrm{~h}$ at $23{ }^{\circ} \mathrm{C}$. The resulting mixture was stopped with addition of sat. aq. $\mathrm{NH}_{4} \mathrm{Cl}(8 \mathrm{~mL})$, diluted with EtOAc $(8 \mathrm{~mL})$, and the organic phase was separated. The aqueous phase was extracted with EtOAc $(3 \times 8 \mathrm{~mL})$ and the combined organic layers were washed with brine $(20 \mathrm{~mL})$, dried over anhydrous $\mathrm{Na}_{2} \mathrm{SO}_{4}$, filtered, and concentrated under reduced pressure by rotary evaporation. Purification by flash column chromatography on silica gel (hexanes/EtOAc $=1: 1$ to $1: 2$ ) afforded the title product as an off white solid (40 mg, 85\%). M.P.: 96-97 ${ }^{\circ} \mathrm{C} ; \mathbf{R}_{\mathbf{f}}=0.24$ (hexanes/EtOAc $=1: 2) ;{ }^{1} \mathbf{H}$ NMR $\left(400 \mathrm{MHz}, \mathrm{CDCl}_{3}\right): \delta 7.56(\mathrm{~d}, J=9.6 \mathrm{~Hz}, 1 \mathrm{H}), 7.42(\mathrm{~d}, J=8.4 \mathrm{~Hz}, 1 \mathrm{H})$, $6.78(\mathrm{dd}, J=8.8,2.0 \mathrm{~Hz}, 1 \mathrm{H}), 6.74(\mathrm{~d}, J=2.0 \mathrm{~Hz}, 1 \mathrm{H}), 6.51(\mathrm{~d}, J=9.2 \mathrm{~Hz}, 1 \mathrm{H}), 3.89$ (s, 3H), $3.64(\mathrm{~s}, 3 \mathrm{H}) ;{ }^{13} \mathrm{C}$ NMR (100 MHz, $\left.\mathrm{CDCl}_{3}\right): \delta$ 162.8, 161.8, 141.7, 138.8, 130.1, 118.5, 114.9, 109.6, 98.7, 55.6, 29.5; IR ( $\left.\mathrm{cm}^{-1}\right): 2919,1643,1620,1590,1563,1508$, 1418, 1388, 1364, 1223, 1134, 1036, 826; ESI-HRMS $(\mathrm{m} / \mathrm{z}):[\mathrm{M}+\mathrm{H}]^{+}$calc'd for $\mathrm{C}_{11} \mathrm{H}_{12} \mathrm{NO}_{2}$ : 190.0863; found: 190.0865 . 


\section{(E)-5-Hydroxy-1-(piperidin-1-yl)pent-2-en-1-one 2t}

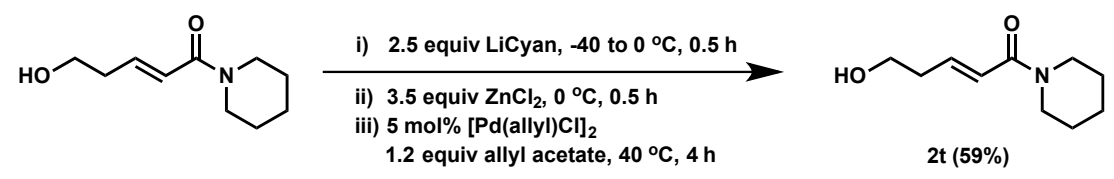

To a $-40{ }^{\circ} \mathrm{C}$ solution of $\mathrm{N}$-cyclohexyl-2,6-diisopropylaniline $(130 \mathrm{mg}, 0.50 \mathrm{mmol}$, 2.5 equiv) in THF (2.0 mL, $0.25 \mathrm{M})$ was added $n$-BuLi (2.5 M in hexanes, $0.30 \mathrm{~mL}, 0.50$ mmol, 2.5 equiv). After 3-5 mins, the reaction mixture became cloudy, and was stirred for $1 \mathrm{~h}$. Amide $1 \mathrm{t}$ (37 mg, $0.20 \mathrm{mmol}, 1.0$ equiv) was added dropwise into the reaction mixture and the mixture became clear immediately. The resulting solution was moved into an ice-water bath and stirred for $30 \mathrm{~min}$. $\mathrm{ZnCl}_{2}(0.5 \mathrm{M}$ in THF, $1.4 \mathrm{~mL}, 0.7 \mathrm{mmol}$, 3.5 equiv) was added and stirred for $30 \mathrm{~min}$. The stock solution of $[\mathrm{Pd}(\text { allyl }) \mathrm{Cl}]_{2}(3.7 \mathrm{mg}$, $0.01 \mathrm{mmol}, 0.05$ equiv) and allyl acetate (24 mg, $0.24 \mathrm{mmol}, 1.2$ equiv) in THF (0.20 $\mathrm{mL}$ ) was next added at the same temperature. The reaction mixture was placed into a preheated $40{ }^{\circ} \mathrm{C}$ oil bath and stirred for $4 \mathrm{~h}$. The resulting mixture was cooled to room temperature and stopped with the addition of sat. aq. $\mathrm{NH}_{4} \mathrm{Cl}(8 \mathrm{~mL})$, diluted with EtOAc $(8 \mathrm{~mL})$, and the organic phase was separated. The aqueous phase was extracted with EtOAc $(3 \times 8 \mathrm{~mL})$ and the combined organic layers were washed with brine $(20 \mathrm{~mL})$, dried over anhydrous $\mathrm{Na}_{2} \mathrm{SO}_{4}$, filtered, and concentrated under reduced pressure by rotary evaporation. Purification by flash column chromatography on silica gel $(\mathrm{DCM} / \mathrm{MeOH}=$ $1: 0$ to $20: 1)$ then preparative thin layer chromatography on silica gel $\left(\mathrm{CHCl}_{3} / \mathrm{MeOH}=\right.$ 15:1) afforded the title product as a colorless oil (22 mg, 59\%). $\mathbf{R}_{\mathbf{f}}=0.27(\mathrm{EtOAc} / \mathrm{MeOH}$ $=10: 1) ;{ }^{1} \mathbf{H}$ NMR $\left(400 \mathrm{MHz}, \mathrm{CDCl}_{3}\right): \delta 6.80(\mathrm{dd}, J=15.2,3.6 \mathrm{~Hz}, 1 \mathrm{H}), 6.46(\mathrm{~d}, J=15.2$ $\mathrm{Hz}, 1 \mathrm{H}), 4.46(\mathrm{~m}, 1 \mathrm{H}), 3.58(\mathrm{~m}, 2 \mathrm{H}), 3.48(\mathrm{~m}, 2 \mathrm{H}), 2.59(\mathrm{~m}, 1 \mathrm{H}), 1.64-1.55(\mathrm{~m}, 6 \mathrm{H})$, $1.31(\mathrm{~d}, J=6.4 \mathrm{~Hz}, 3 \mathrm{H}) ;{ }^{13} \mathrm{C}$ NMR $\left(100 \mathrm{MHz}, \mathrm{CDCl}_{3}\right): \delta 165.5,148.2,118.6,67.5,47.1$, 43.3, 26.8, 25.7, 24.7, 23.1; IR $\left(\mathrm{cm}^{-1}\right): 3384,2933,2857,1657,1595,1442,1267,1138$, 1020, 850; ESI-HRMS (m/z): $[\mathrm{M}+\mathrm{H}]^{+}$calc'd for $\mathrm{C}_{10} \mathrm{H}_{18} \mathrm{NO}_{2}:$ 184.1313; found: 184.1316 . 


\section{1-Benzyl-4-(hydroxymethyl)-1,5-dihydro-2H-pyrrol-2-one $2 u$}

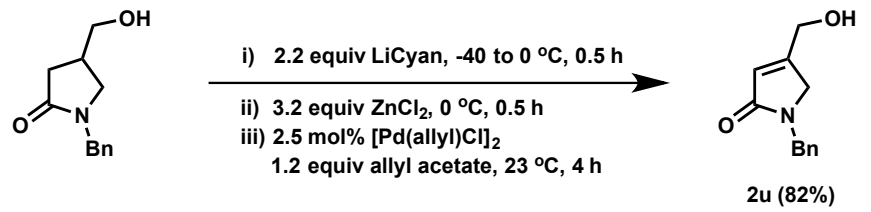

To a $-40{ }^{\circ} \mathrm{C}$ solution of $N$-cyclohexyl-2,6-diisopropylaniline (114 $\mathrm{mg}, 0.44 \mathrm{mmol}$, 2.2 equiv) in THF (3.0 mL, $0.15 \mathrm{M})$ was added $n$-BuLi (2.5 M in hexanes, $0.18 \mathrm{~mL}, 0.44$ mmol, 2.5 equiv). After 3-5 mins, the reaction mixture became cloudy, and was stirred for $1 \mathrm{~h}$. Lactam $1 \mathbf{u}(41 \mathrm{mg}, 0.20 \mathrm{mmol}, 1.0$ equiv) was added dropwise into the reaction mixture and the mixture became clear immediately. The resulting solution was moved into an ice-water bath and stirred for $30 \mathrm{~min}$. $\mathrm{ZnCl}_{2}(0.5 \mathrm{M}$ in THF, $1.3 \mathrm{~mL}, 0.64 \mathrm{mmol}$, 3.2 equiv) was added and stirred for $30 \mathrm{~min}$. The stock solution of [Pd(allyl)Cl $]_{2}(1.8 \mathrm{mg}$, $0.005 \mathrm{mmol}, 0.025$ equiv) and allyl acetate (24 mg, $0.24 \mathrm{mmol}, 1.2$ equiv) in THF (0.20 $\mathrm{mL}$ ) was next added at the same temperature. The reaction mixture was removed from the ice bath and stirred for $4 \mathrm{~h}$ at $23{ }^{\circ} \mathrm{C}$. The resulting mixture was stopped with addition of sat. aq. $\mathrm{NH}_{4} \mathrm{Cl}(8 \mathrm{~mL})$, diluted with EtOAc $(8 \mathrm{~mL})$, and the organic phase was separated. The aqueous phase was extracted with EtOAc $(3 \times 8 \mathrm{~mL})$ and the combined organic layers were washed with brine $(20 \mathrm{~mL})$, dried over anhydrous $\mathrm{Na}_{2} \mathrm{SO}_{4}$, filtered, and concentrated under reduced pressure by rotary evaporation. Purification by flash column chromatography on silica gel (hexanes/EtOAc $=1: 3$ then $\mathrm{EtOAc} / \mathrm{MeOH}=10: 1$ ) afforded the title product as a yellow solid (33 mg, 82\%). M.P.: $58-60{ }^{\circ} \mathrm{C} ; \mathbf{R}_{\mathbf{f}}=0.18$ (EtOAc); ${ }^{1} \mathbf{H}$ NMR (400 MHz, $\left.\mathrm{CDCl}_{3}\right): \delta 7.34-7.27(\mathrm{~m}, 3 \mathrm{H}), 7.22(\mathrm{~d}, J=6.8 \mathrm{~Hz}, 2 \mathrm{H})$, $6.05(\mathrm{~s}, 1 \mathrm{H}), 4.58(\mathrm{~s}, 2 \mathrm{H}), 4.43$ (s, 2H), 3.86 (s, 2H), 3.69 (bs, 1H); ${ }^{13} \mathbf{C}$ NMR (100 MHz, $\left.\mathrm{CDCl}_{3}\right): \delta 172.8,159.8,137.1,128.9,128.1,127.8,121.3,59.8,52.1,46.1 ;$ IR $\left(\mathrm{cm}^{-1}\right)$ : 3300, 2923, 1652, 1620, 1448, 1287, 1047, 855; ESI-HRMS (m/z): [M+H] $]^{+}$calc'd for $\mathrm{C}_{12} \mathrm{H}_{14} \mathrm{NO}_{2}$ : 204.1020; found: 204.0999. 


\section{Amide 2v}
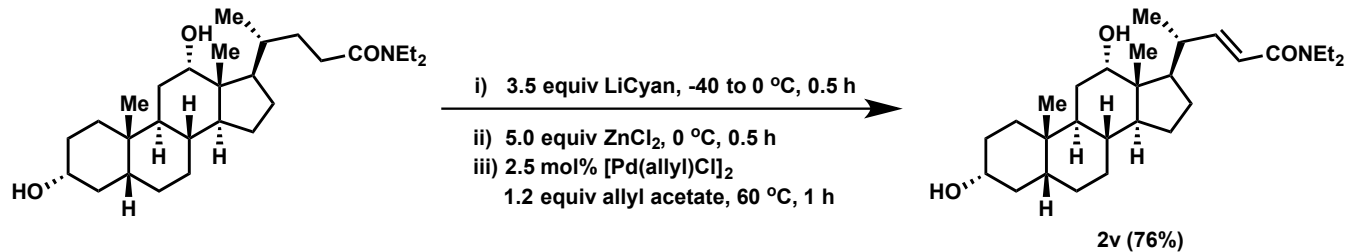

To a $-40{ }^{\circ} \mathrm{C}$ solution of $N$-cyclohexyl-2,6-diisopropylaniline $(91 \mathrm{mg}, 0.35 \mathrm{mmol}$, 3.5 equiv) in THF (2.0 mL, $0.18 \mathrm{M})$ was added $n$-BuLi (2.5 M in hexanes, $0.14 \mathrm{~mL}, 0.35$ mmol, 3.5 equiv). After 3-5 mins, the reaction mixture became cloudy, and was stirred for $1 \mathrm{~h}$. Amide $1 \mathrm{v}$ (45 mg, $0.10 \mathrm{mmol}, 1.0$ equiv) was added dropwise into the reaction mixture and the mixture became clear immediately. The resulting solution was moved into an ice-water bath and stirred for $30 \mathrm{~min}$. $\mathrm{ZnCl}_{2}(0.5 \mathrm{M}$ in THF, $1.0 \mathrm{~mL}, 0.50 \mathrm{mmol}$, 5.0 equiv) was added and stirred for $30 \mathrm{~min}$. The stock solution of $[\mathrm{Pd}(\text { allyl }) \mathrm{Cl}]_{2}(0.9 \mathrm{mg}$, $0.0025 \mathrm{mmol}, 0.025$ equiv) and allyl acetate (12 $\mathrm{mg}, 0.12 \mathrm{mmol}, 1.2$ equiv) in THF (0.10 $\mathrm{mL}$ ) was next added at the same temperature. The reaction mixture was placed into a preheated $60{ }^{\circ} \mathrm{C}$ oil bath and stirred for $1 \mathrm{~h}$. The resulting mixture was cooled to room temperature and stopped with the addition of sat. aq. $\mathrm{NH}_{4} \mathrm{Cl}(8 \mathrm{~mL})$, diluted with EtOAc $(8 \mathrm{~mL})$, and the organic phase was separated. The aqueous phase was extracted with EtOAc $(3 \times 8 \mathrm{~mL})$ and the combined organic layers were washed with brine $(20 \mathrm{~mL})$, dried over anhydrous $\mathrm{Na}_{2} \mathrm{SO}_{4}$, filtered, and concentrated under reduced pressure by rotary evaporation. Purification by flash column chromatography on silica gel (hexanes/acetone $=1: 1$ to $1: 2)$ afforded the title product as a white solid (38 mg, 76\%). M.P.: $93-95{ }^{\circ} \mathrm{C} ; \mathbf{R}_{\mathbf{f}}$ $=0.27$ (hexanes/acetone $=1: 1) ;[\alpha]_{\mathrm{D}}^{23}+28.2\left(c, 0.89, \mathrm{CHCl}_{3}\right) ;{ }^{1} \mathbf{H} \mathbf{~ N M R}(400 \mathrm{MHz}$, $\left.\mathrm{CDCl}_{3}\right): \delta 6.76(\mathrm{dd}, J=15.6,8.8 \mathrm{~Hz}, 1 \mathrm{H}), 6.08(\mathrm{~d}, J=14.8 \mathrm{~Hz}, 1 \mathrm{H}), 3.96(\mathrm{~s}, 1 \mathrm{H}), 3.58$ (sept, $J=4.4 \mathrm{~Hz}, 1 \mathrm{H}), 3.45-3.23$ (m, 4H), 2.26-2.14 (m, 4H), 1.92-1.64 (m, 7H), 1.59$1.42(\mathrm{~m}, 9 \mathrm{H}), 1.32-0.96(\mathrm{~m}, 13 \mathrm{H}), 0.89$ (s, 3H), 0.70 (s, 3H); ${ }^{13} \mathbf{C}$ NMR (100 MHz, $\left.\mathrm{CDCl}_{3}\right): \delta 166.3,151.5,118.2,73.0,71.8,48.2,46.8,46.6,42.3,42.2,40.9,40.0,36.5$, $36.1,35.4,34.3,33.8,30.5,28.9,27.7,27.3,26.3,23.9,23.3,18.8,15.0,13.3$, 13.1; IR $\left(\mathrm{cm}^{-1}\right): 3380,2975,2931,2867,1654,1602,1447,1118,790 ;$ ESI-HRMS (m/z): $[\mathrm{M}+\mathrm{H}]^{+}$calc'd for $\mathrm{C}_{28} \mathrm{H}_{48} \mathrm{NO}_{3}$ : 446.3629; found: 446.3605 . 


\section{1-Benzyl-5-hydroxy-1,5-dihydro-2H-pyrrol-2-one $2 \mathrm{w}$}

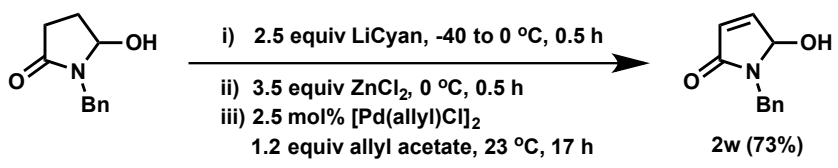

To a $-40{ }^{\circ} \mathrm{C}$ solution of $\mathrm{N}$-cyclohexyl-2,6-diisopropylaniline $(130 \mathrm{mg}, 0.50 \mathrm{mmol}$, 2.5 equiv) in THF (3.0 mL, $0.17 \mathrm{M})$ was added $n$-BuLi (2.5 M in hexanes, $0.20 \mathrm{~mL}, 0.50$ mmol, 2.5 equiv). After 3-5 mins, the reaction mixture became cloudy, and was stirred for $1 \mathrm{~h}$. Lactam $1 \mathbf{w}$ (38 $\mathrm{mg}, 0.20 \mathrm{mmol}, 1.0$ equiv) was added dropwise into the reaction mixture and the mixture became clear immediately. The resulting solution was moved into an ice-water bath and stirred for $30 \mathrm{~min}$. $\mathrm{ZnCl}_{2}(0.5 \mathrm{M}$ in THF, $1.4 \mathrm{~mL}, 0.7 \mathrm{mmol}$, 3.5 equiv) was added and stirred for $30 \mathrm{~min}$. The stock solution of $\left[\mathrm{Pd}(\right.$ allyl $) \mathrm{Cl}_{2}(1.8 \mathrm{mg}$, $0.005 \mathrm{mmol}, 0.025$ equiv) and allyl acetate (24 mg, $0.24 \mathrm{mmol}, 1.2$ equiv) in THF (0.20 $\mathrm{mL}$ ) was next added at the same temperature. The reaction mixture was removed from the ice bath and stirred for $17 \mathrm{~h}$ at $23{ }^{\circ} \mathrm{C}$. The resulting mixture was stopped with addition of sat. aq. $\mathrm{NH}_{4} \mathrm{Cl}(8 \mathrm{~mL})$, diluted with EtOAc $(8 \mathrm{~mL})$, and the organic phase was separated. The aqueous phase was extracted with EtOAc $(3 \times 8 \mathrm{~mL})$ and the combined organic layers were washed with brine $(20 \mathrm{~mL})$, dried over anhydrous $\mathrm{Na}_{2} \mathrm{SO}_{4}$, filtered, and concentrated under reduced pressure by rotary evaporation. Purification by flash column chromatography on silica gel (hexanes/EtOAc $=1: 1$ to $1: 3$ ) afforded the title product as a white solid (28 mg, 73\%). M.P.: 108-109 ${ }^{\circ} \mathrm{C} ; \mathbf{R}_{\mathbf{f}}=0.32$ (hexanes/EtOAc $=$ $1: 3) ;{ }^{1} \mathbf{H}$ NMR $\left(400 \mathrm{MHz}, \mathrm{CDCl}_{3}\right): \delta 7.32-7.24(\mathrm{~m}, 5 \mathrm{H}), 6.92(\mathrm{~d}, J=4.2 \mathrm{~Hz}, 1 \mathrm{H}), 6.09$ $(\mathrm{d}, J=6.0 \mathrm{~Hz}, 1 \mathrm{H}), 5.24(\mathrm{~d}, J=10.8 \mathrm{~Hz}, 1 \mathrm{H}), 4.89(1 / 2 \mathrm{ABq}, J=14.8 \mathrm{~Hz}, 1 \mathrm{H}), 4.21$ $(1 / 2 \mathrm{ABq}, J=14.8 \mathrm{~Hz}, 1 \mathrm{H}), 4.07(\mathrm{~d}, J=10.8 \mathrm{~Hz}, 1 \mathrm{H}) ;{ }^{13} \mathbf{C ~ N M R}\left(100 \mathrm{MHz}, \mathrm{CDCl}_{3}\right): \delta$ 169.7, 146.4, 137.1, 128.9, 128.3, 128.2, 127.7, 82.8, 42.7; IR $\left(\mathrm{cm}^{-1}\right): 3153,2931,1659$, 1592, 1441, 1420, 1241. 1084, 700; ESI-HRMS (m/z): [M+H] $]^{+}$calc'd for $\mathrm{C}_{11} \mathrm{H}_{12} \mathrm{NO}_{2}$ : 190.0863; found: 190.0843 . 


\section{(E)-5-Hydroxy-1-(piperidin-1-yl)pent-2-en-1-one 2x}

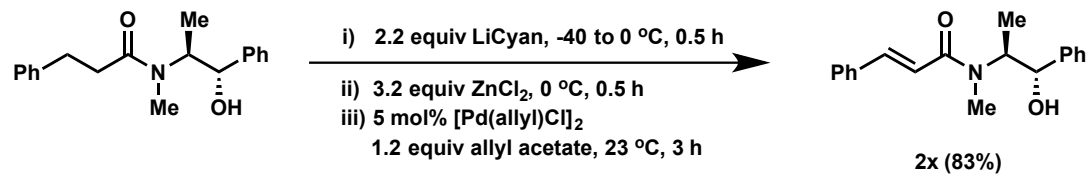

To a $-40{ }^{\circ} \mathrm{C}$ solution of $\mathrm{N}$-cyclohexyl-2,6-diisopropylaniline (114 $\mathrm{mg}, 0.44 \mathrm{mmol}$, 2.2 equiv) in THF (3.0 mL, $0.15 \mathrm{M})$ was added $n$-BuLi (2.5 M in hexanes, $0.18 \mathrm{~mL}, 0.44$ mmol, 2.5 equiv). After 3-5 mins, the reaction mixture became cloudy, and was stirred for $1 \mathrm{~h}$. Amide $1 \times$ (60 mg, $0.20 \mathrm{mmol}, 1.0$ equiv) was added dropwise into the reaction mixture and the mixture became clear immediately. The resulting solution was moved into an ice-water bath and stirred for $30 \mathrm{~min}$. $\mathrm{ZnCl}_{2}(0.5 \mathrm{M}$ in THF, $1.3 \mathrm{~mL}, 0.64 \mathrm{mmol}$, 3.2 equiv) was added and stirred for $30 \mathrm{~min}$. The stock solution of $\left[\mathrm{Pd}(\right.$ allyl $) \mathrm{Cl}_{2}(1.8 \mathrm{mg}$, $0.005 \mathrm{mmol}, 0.025$ equiv) and allyl acetate (24 mg, $0.24 \mathrm{mmol}, 1.2$ equiv) in THF (0.20 $\mathrm{mL}$ ) was next added at the same temperature. The reaction mixture was removed from the ice bath and stirred for $3 \mathrm{~h}$ at $23{ }^{\circ} \mathrm{C}$. The resulting mixture was stopped with addition of sat. aq. $\mathrm{NH}_{4} \mathrm{Cl}(8 \mathrm{~mL})$, diluted with EtOAc $(8 \mathrm{~mL})$, and the organic phase was separated. The aqueous phase was extracted with EtOAc $(3 \times 8 \mathrm{~mL})$ and the combined organic layers were washed with brine $(20 \mathrm{~mL})$, dried over anhydrous $\mathrm{Na}_{2} \mathrm{SO}_{4}$, filtered, and concentrated under reduced pressure by rotary evaporation. Purification by flash column chromatography on silica gel (hexanes/EtOAc $=1: 1$ to $1: 2$ ) afforded the title product as an off white solid (49 mg, 83\%). M.P.: $138-139{ }^{\circ} \mathrm{C} ; \quad \mathbf{R}_{\mathbf{f}}=0.27$ (hexanes/EtOAc $=1: 2) ;[\alpha]_{\mathrm{D}}^{23}+146.5\left(c, 1.09, \mathrm{CHCl}_{3}\right) ;{ }^{1} \mathbf{H} \mathbf{~ N M R}\left(400 \mathrm{MHz}, \mathrm{CDCl}_{3}\right): \delta$ $7.67(\mathrm{~d}, J=15.2 \mathrm{~Hz}, 0.75 \mathrm{H}), 7.55-7.44(\mathrm{~m}, 2.4 \mathrm{H}), 7.39-7.15(\mathrm{~m}, 8 \mathrm{H}), 6.94(\mathrm{~d}, J=15.6$ $\mathrm{Hz}, 0.36 \mathrm{H}), 6.79(\mathrm{~d}, J=15.2 \mathrm{~Hz}, 0.68 \mathrm{H}), 4.64-4.54(\mathrm{~m}, 1.8 \mathrm{H}), 4.21$ (quint, $J=2.8 \mathrm{~Hz}$, $0.53 \mathrm{H}), 2.99,2.97(\mathrm{~s}, 3 \mathrm{H}), 1.10(\mathrm{~d}, J=5.6 \mathrm{~Hz}, 2.09 \mathrm{H}), 1.02(\mathrm{~d}, J=6.8 \mathrm{~Hz}, 0.95 \mathrm{H}) ;{ }^{13} \mathrm{C}$ NMR $\left(100 \mathrm{MHz}, \mathrm{CDCl}_{3}\right): \delta 168.9,168.5,143.3,142.5,141.6,141.5,135.6,135.2$, $129.8,129.5,129.3,128.9,128.7,128.7,128.5,128.3,127.9,127.7,126.7,126.7,119.1$, $119.1,114.0,76.6,75.6,58.8,58.6,55.3,49.5,47.0,32.6,32.4,27.8,23.2,21.4,15.6$, 14.6; (The product results in two sets of NMR signals, due to the presence of rotamers around the $\mathbf{N}, \mathbf{N}$-disubstituted amide.); IR $\left(\mathrm{cm}^{-1}\right): 3267,3975,1596,1439$, 1120, 1025, 775; ESI-HRMS (m/z): $[\mathrm{M}+\mathrm{H}]^{+}$calc'd for $\mathrm{C}_{19} \mathrm{H}_{22} \mathrm{NO}_{2}$ : 296.1646; found: 296.1626. 


\section{7-Hydroxy-1-methylquinolin-2(1H)-one $2 y$}

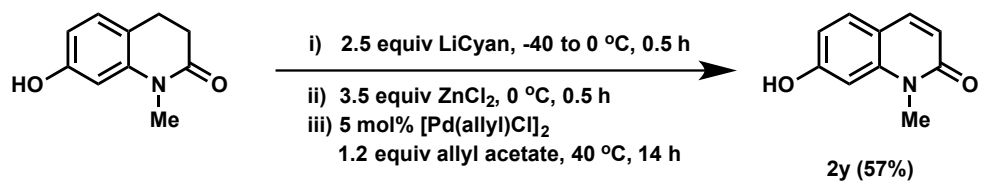

To a $-40{ }^{\circ} \mathrm{C}$ solution of $N$-cyclohexyl-2,6-diisopropylaniline $(130 \mathrm{mg}, 0.50 \mathrm{mmol}$, 2.5 equiv) in THF (3.0 mL, $0.17 \mathrm{M})$ was added $n$-BuLi (2.5 M in hexanes, $0.20 \mathrm{~mL}, 0.50$ mmol, 2.5 equiv). After 3-5 mins, the reaction mixture became cloudy, and was stirred for $1 \mathrm{~h}$. Lactam 1y (35 mg, $0.20 \mathrm{mmol}, 1.0$ equiv) was added dropwise into the reaction mixture and the mixture became clear immediately. The resulting solution was moved into an ice-water bath and stirred for $30 \mathrm{~min}$. $\mathrm{ZnCl}_{2}(0.5 \mathrm{M}$ in THF, $1.4 \mathrm{~mL}, 0.70 \mathrm{mmol}$, 3.5 equiv) was added and stirred for $30 \mathrm{~min}$. The stock solution of [Pd(allyl)Cl $]_{2}(3.6 \mathrm{mg}$, $0.01 \mathrm{mmol}, 0.05$ equiv) and allyl acetate $(24 \mathrm{mg}, 0.24 \mathrm{mmol}, 1.2$ equiv) in THF (0.10 $\mathrm{mL}$ ) was next added at the same temperature. The reaction mixture was placed into a preheated $40{ }^{\circ} \mathrm{C}$ oil bath and stirred for $14 \mathrm{~h}$. The resulting mixture was cooled to room temperature and stopped with the addition of sat. aq. $\mathrm{NH}_{4} \mathrm{Cl}(8 \mathrm{~mL})$, diluted with EtOAc $(8 \mathrm{~mL})$, and the organic phase was separated. The aqueous phase was extracted with EtOAc $(3 \times 8 \mathrm{~mL})$ and the combined organic layers were washed with brine $(20 \mathrm{~mL})$, dried over anhydrous $\mathrm{Na}_{2} \mathrm{SO}_{4}$, filtered, and concentrated under reduced pressure by rotary evaporation. Purification by flash column chromatography on silica gel (hexanes/EtOAc $=1: 1$ to $1: 2)$ afforded starting material $1 \mathbf{y}(14 \mathrm{mg}, 39 \%)$ and the title product as a white solid (20 mg, 57\%). $\mathbf{R}_{\mathbf{f}}=0.17$ (hexanes/EtOAc = 1:2); ${ }^{1} \mathbf{H}$ NMR (400 MHz, $\left.\mathrm{C}_{2} \mathrm{D}_{6} \mathrm{SO}\right): \delta$ $10.3(\mathrm{~s}, 1 \mathrm{H}), 7.75(\mathrm{~d}, J=9.2,1 \mathrm{H}), 7.52(\mathrm{~d}, J=8.4,1 \mathrm{H}), 6.79(\mathrm{~s}, 1 \mathrm{H}), 6.72(\mathrm{~d}, J=10.0$ $\mathrm{Hz}, 1 \mathrm{H}), 6.35(\mathrm{~d}, J=9.2 \mathrm{~Hz}, 1 \mathrm{H}), 3.52$ (s, 3H); ${ }^{13} \mathrm{C}$ NMR (100 MHz, $\left.\mathrm{C}_{2} \mathrm{D}_{6} \mathrm{SO}\right): \delta 161.5$, 160.1, 141.7, 139.1, 130.3, 116.6, 113.2, 111.1, 100.0, 28.9; IR (cm $\left.{ }^{-1}\right): 2923,2851,1630$, 1549, 1339, 1232, 830; ESI-HRMS (m/z): $[\mathrm{M}+\mathrm{H}]^{+}$calc'd for $\mathrm{C}_{10} \mathrm{H}_{10} \mathrm{NO}_{2}$ : 176.0707; found: 176.0692 . 
(E)-N,N-dibenzyl-3-(1H-indol-3-yl)acrylamide $2 \mathrm{z}$

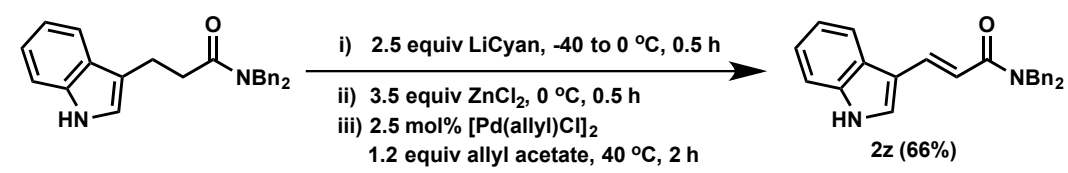

To a $-40{ }^{\circ} \mathrm{C}$ solution of $N$-cyclohexyl-2,6-diisopropylaniline $(130 \mathrm{mg}, 0.50 \mathrm{mmol}$, 2.5 equiv) in THF ( $3.0 \mathrm{~mL}, 0.17 \mathrm{M})$ was added $n-\mathrm{BuLi}(2.5 \mathrm{M}$ in hexanes, $0.20 \mathrm{~mL}, 0.50$ mmol, 2.5 equiv). After 3-5 mins, the reaction mixture became cloudy, and was stirred for $1 \mathrm{~h}$. Amide $1 \mathrm{z}$ (74 $\mathrm{mg}, 0.2 \mathrm{mmol}, 1.0$ equiv) was added dropwise into the reaction mixture and the mixture became clear immediately. The resulting solution was moved into an ice-water bath and stirred for $30 \mathrm{~min}$. $\mathrm{ZnCl}_{2}(0.5 \mathrm{M}$ in THF, $1.4 \mathrm{~mL}, 0.7 \mathrm{mmol}$, 3.5 equiv) was added and stirred for $30 \mathrm{~min}$. The stock solution of $[\mathrm{Pd}(\text { allyl }) \mathrm{Cl}]_{2}(1.8 \mathrm{mg}$, $0.005 \mathrm{mmol}, 0.025$ equiv) and allyl acetate ( $24 \mathrm{mg}, 0.24 \mathrm{mmol}, 1.2$ equiv) in THF ( 0.20 $\mathrm{mL}$ ) was next added at the same temperature. The reaction mixture was placed into a preheated $40{ }^{\circ} \mathrm{C}$ oil bath and stirred for $2 \mathrm{~h}$. The resulting mixture was cooled to room temperature and stopped with the addition of sat. aq. $\mathrm{NH}_{4} \mathrm{Cl}(8 \mathrm{~mL})$, diluted with EtOAc $(8 \mathrm{~mL})$, and the organic phase was separated. The aqueous phase was extracted with EtOAc $(3 \times 8 \mathrm{~mL})$ and the combined organic layers were washed with brine $(20 \mathrm{~mL})$, dried over anhydrous $\mathrm{Na}_{2} \mathrm{SO}_{4}$, filtered, and concentrated under reduced pressure by rotary evaporation. Purification by flash column chromatography on silica gel (hexanes/EtOAc $=2: 1$ to $1: 1)$ afforded the title product as a tan solid $(48 \mathrm{mg}, 66 \%)$. M.P.: $190-192{ }^{\circ} \mathrm{C} ; \mathbf{R}_{\mathbf{f}}$ $=0.32($ hexanes $/$ EtOAc $=1: 3) ;{ }^{1} \mathbf{H}$ NMR $\left(600 \mathrm{MHz}, \mathrm{CDCl}_{3}\right): \delta 8.76(\mathrm{~s}, 1 \mathrm{H}), 8.08(\mathrm{~d}, J=$ $15.6 \mathrm{~Hz}, 1 \mathrm{H}), 7.55$ (d, $J=7.8 \mathrm{~Hz}, 1 \mathrm{H}), 7.42(\mathrm{~d}, J=2.4 \mathrm{~Hz}, 1 \mathrm{H}), 7.40-7.29(\mathrm{~m}, 11 \mathrm{H})$, 7.21 (t, $J=7.8 \mathrm{~Hz}, 1 \mathrm{H}), 7.11$ (t, $J=7.2 \mathrm{~Hz}, 1 \mathrm{H}), 6.91$ (d, $J=15.0 \mathrm{~Hz}, 1 \mathrm{H}), 4.78(\mathrm{~s}, 2 \mathrm{H})$, 4.66 (s, 2H); ${ }^{13}$ C NMR $\left(150 \mathrm{MHz}, \mathrm{CDCl}_{3}\right): \delta 168.6,137.8,137.6,137.4,137.2,129.1$, $128.8,128.6,128.4,127.8,127.5,126.8,125.4,123.2,121.3,120.3,114.2,112.8,111.9$, 50.5, 49.3; IR ( $\left.\mathrm{cm}^{-1}\right): 3170,1628,1569,1470,1442,1224,1064,1026,845$; ESI-HRMS $(\mathrm{m} / \mathrm{z}):[\mathrm{M}+\mathrm{H}]^{+}$calc'd for $\mathrm{C}_{25} \mathrm{H}_{23} \mathrm{~N}_{2} \mathrm{O}: 367.1805$; found: 367.1797 . 


\section{(E)-4-(1H-indol-3-yl)-1-morpholinobut-2-en-1-one 2aa}

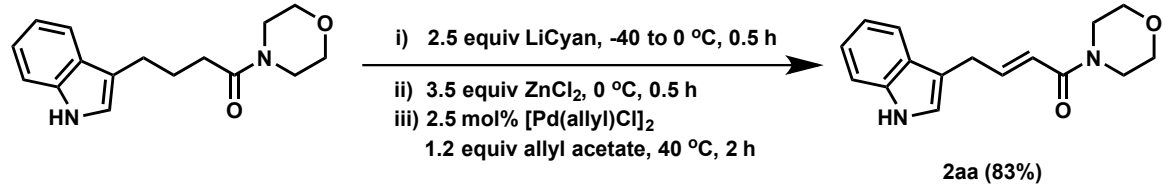

To a $-40{ }^{\circ} \mathrm{C}$ solution of $N$-cyclohexyl-2,6-diisopropylaniline $(130 \mathrm{mg}, 0.50 \mathrm{mmol}$, 2.5 equiv) in THF (3.0 mL, $0.17 \mathrm{M})$ was added $n$-BuLi (2.5 M in hexanes, $0.20 \mathrm{~mL}, 0.50$ mmol, 2.5 equiv). After 3-5 mins, the reaction mixture became cloudy, and was stirred for $1 \mathrm{~h}$. Amide 1aa (55 mg, $0.2 \mathrm{mmol}, 1.0$ equiv) was added dropwise into the reaction mixture and the mixture became clear immediately. The resulting solution was moved into an ice-water bath and stirred for $30 \mathrm{~min}$. $\mathrm{ZnCl}_{2}(0.5 \mathrm{M}$ in THF, $1.4 \mathrm{~mL}, 0.7 \mathrm{mmol}$, 3.5 equiv) was added and stirred for $30 \mathrm{~min}$. The stock solution of $\left[\mathrm{Pd}(\right.$ allyl $) \mathrm{Cl}_{2}(1.8 \mathrm{mg}$, $0.005 \mathrm{mmol}, 0.025$ equiv) and allyl acetate (24 mg, $0.24 \mathrm{mmol}, 1.2$ equiv) in THF (0.20 $\mathrm{mL}$ ) was next added at the same temperature. The reaction mixture was placed into a preheated $40{ }^{\circ} \mathrm{C}$ oil bath and stirred for $2 \mathrm{~h}$. The resulting mixture was cooled to room temperature and stopped with the addition of sat. aq. $\mathrm{NH}_{4} \mathrm{Cl}(8 \mathrm{~mL})$, diluted with EtOAc $(8 \mathrm{~mL})$, and the organic phase was separated. The aqueous phase was extracted with EtOAc $(3 \times 8 \mathrm{~mL})$ and the combined organic layers were washed with brine $(20 \mathrm{~mL})$, dried over anhydrous $\mathrm{Na}_{2} \mathrm{SO}_{4}$, filtered, and concentrated under reduced pressure by rotary evaporation. Purification by flash column chromatography on silica gel (hexanes/EtOAc $=1: 1$ to $0: 1)$ afforded the title product as a yellow solid (45 mg, 83\%). M.P.: 128-130 ${ }^{\circ} \mathrm{C} ; \mathbf{R}_{\mathbf{f}}=0.48$ (EtOAc); ${ }^{1} \mathbf{H}$ NMR (400 MHz, $\left.\mathrm{CDCl}_{3}\right): \delta 8.57(\mathrm{~s}, 1 \mathrm{H}), 7.52(\mathrm{~d}, J=7.6 \mathrm{~Hz}$, 1H), $7.36(\mathrm{~d}, J=8.0 \mathrm{~Hz}, 1 \mathrm{H}), 7.20-7.08(\mathrm{~m}, 3 \mathrm{H}), 6.94$ (t, $J=1.6 \mathrm{~Hz}, 1 \mathrm{H}), 6.24$ (d, $J=$ $15.2 \mathrm{~Hz}, 1 \mathrm{H}), 3.67-3.61(\mathrm{~m}, 8 \mathrm{H}), 3.43(\mathrm{~s}, 2 \mathrm{H}) ;{ }^{13} \mathbf{C}$ NMR (100 MHz, $\left.\mathrm{CDCl}_{3}\right): \delta 166.1$, $145.4,136.5,127.2,122.4,122.1,120.3,119.4,118.8,112.2,111.4,66.8,46.2,42.3$, 28.5; IR $\left(\mathrm{cm}^{-1}\right): 3228,2853,1648,1601,1457,1437,1297,1225,1147,984,736$; ESI$\operatorname{HRMS}(\mathrm{m} / \mathrm{z}):[\mathrm{M}+\mathrm{H}]^{+}$calc'd for $\mathrm{C}_{16} \mathrm{H}_{19} \mathrm{~N}_{2} \mathrm{O}_{2}$ : 271.1442; found: 271.1449. 


\section{4-Methyl- $N$-(3-(2-oxo-2,5-dihydro-1 $H$-pyrrol-1-yl)propyl)benzenesulfonamide 2ab}
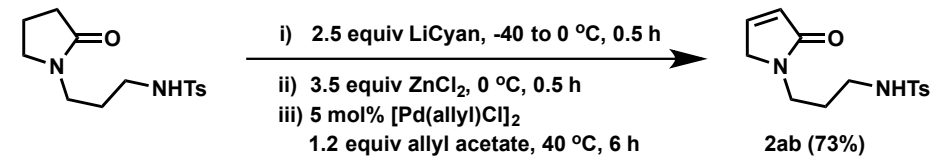

To a $-40{ }^{\circ} \mathrm{C}$ solution of $N$-cyclohexyl-2,6-diisopropylaniline $(130 \mathrm{mg}, 0.50 \mathrm{mmol}$, 2.5 equiv) in THF (3.0 mL, $0.17 \mathrm{M})$ was added $n$-BuLi (2.5 M in hexanes, $0.20 \mathrm{~mL}, 0.50$ mmol, 2.5 equiv). After 3-5 mins, the reaction mixture became cloudy, and was stirred for $1 \mathrm{~h}$. Lactam 1ab (59 $\mathrm{mg}, 0.2 \mathrm{mmol}, 1.0$ equiv) was added dropwise into the reaction mixture and the mixture became clear immediately. The resulting solution was moved into an ice-water bath and stirred for $30 \mathrm{~min}$. $\mathrm{ZnCl}_{2}(0.5 \mathrm{M}$ in THF, $1.4 \mathrm{~mL}, 0.7 \mathrm{mmol}$, 3.5 equiv) was added and stirred for $30 \mathrm{~min}$. The stock solution of [Pd(allyl)Cl $]_{2}(1.8 \mathrm{mg}$, $0.005 \mathrm{mmol}, 0.025$ equiv) and allyl acetate (24 mg, $0.24 \mathrm{mmol}, 1.2$ equiv) in THF (0.20 $\mathrm{mL}$ ) was next added at the same temperature. The reaction mixture was placed into a preheated $40{ }^{\circ} \mathrm{C}$ oil bath and stirred for $6 \mathrm{~h}$. The resulting mixture was cooled to room temperature and stopped with the addition of sat. aq. $\mathrm{NH}_{4} \mathrm{Cl}(8 \mathrm{~mL})$, diluted with EtOAc $(8 \mathrm{~mL})$, and the organic phase was separated. The aqueous phase was extracted with EtOAc $(3 \times 8 \mathrm{~mL})$ and the combined organic layers were washed with brine $(20 \mathrm{~mL})$, dried over anhydrous $\mathrm{Na}_{2} \mathrm{SO}_{4}$, filtered, and concentrated under reduced pressure by rotary evaporation. Purification by flash column chromatography on silica gel (hexanes/EtOAc $=1: 1$ to $0: 1)$ afforded the title product as a tan solid (43 mg, 73\%). M.P.: 87-89 ${ }^{\circ} \mathrm{C} ; \mathbf{R}_{\mathbf{f}}=$ 0.19 (EtOAc); ${ }^{1} \mathbf{H}$ NMR $\left(400 \mathrm{MHz}, \mathrm{CDCl}_{3}\right): \delta 7.72(\mathrm{~d}, J=8.8 \mathrm{~Hz}, 2 \mathrm{H}), 7.26(\mathrm{~d}, J=8.4$ $\mathrm{Hz}, 2 \mathrm{H}), 7.06(\mathrm{~d}, J=5.6 \mathrm{~Hz}, 1 \mathrm{H}), 6.11(\mathrm{~d}, J=5.6 \mathrm{~Hz}, 1 \mathrm{H}), 6.04(\mathrm{t}, J=6.8 \mathrm{~Hz}, 1 \mathrm{H}), 3.94$ (s, 2H), 3.49 (t, $J=6.0 \mathrm{~Hz}, 2 \mathrm{H}), 2.85(\mathrm{q}, J=5.6 \mathrm{~Hz}, 2 \mathrm{H}), 2.38$ (s, 3H), 1.72 (quint, $J=$ $6.4 \mathrm{~Hz}, 2 \mathrm{H}) ;{ }^{13} \mathbf{C}$ NMR (100 MHz, $\left.\mathrm{CDCl}_{3}\right): \delta 172.4,143.3,143.1,137.5,129.7,127.8$, 127.1, 53.2, 39.8, 39.0, 28.7, 21.6; IR (cm $\left.{ }^{-1}\right): 3112,2869,2047,1661,1598,14601245$, 1121, 905, 840; ESI-HRMS (m/z): $[\mathrm{M}+\mathrm{H}]^{+}$calc'd for $\mathrm{C}_{14} \mathrm{H}_{19} \mathrm{~N}_{2} \mathrm{O}_{3} \mathrm{~S}$ : 295.1111; found: 295.1101 . 


\section{(E)- $N, N$-dibenzyl-3-(4-pivalamidophenyl)acrylamide 2ac}

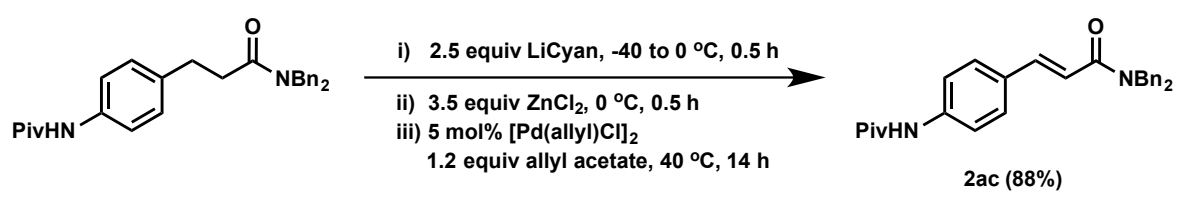

To a $-40{ }^{\circ} \mathrm{C}$ solution of $\mathrm{N}$-cyclohexyl-2,6-diisopropylaniline $(65 \mathrm{mg}, 0.25 \mathrm{mmol}$, 2.5 equiv) in THF (2.0 mL, $0.13 \mathrm{M})$ was added $n-\mathrm{BuLi}(2.5 \mathrm{M}$ in hexanes, $0.10 \mathrm{~mL}, 0.25$ mmol, 2.5 equiv). After 3-5 mins, the reaction mixture became cloudy, and was stirred for $1 \mathrm{~h}$. Amide 1ac (43 mg, $0.1 \mathrm{mmol}, 1.0$ equiv) was added dropwise into the reaction mixture and the mixture became clear immediately. The resulting solution was moved into an ice-water bath and stirred for $30 \mathrm{~min}$. $\mathrm{ZnCl}_{2}(0.5 \mathrm{M}$ in THF, $0.7 \mathrm{~mL}, 0.35 \mathrm{mmol}$, 3.5 equiv) was added and stirred for $30 \mathrm{~min}$. The stock solution of $[\mathrm{Pd}(\text { allyl }) \mathrm{Cl}]_{2}(1.8 \mathrm{mg}$, $0.005 \mathrm{mmol}, 0.05$ equiv) and allyl acetate (12 $\mathrm{mg}, 0.12 \mathrm{mmol}, 1.2$ equiv) in THF (0.10 $\mathrm{mL}$ ) was next added at the same temperature. The reaction mixture was placed into a preheated $40{ }^{\circ} \mathrm{C}$ oil bath and stirred for $14 \mathrm{~h}$. The resulting mixture was cooled to room temperature and stopped with the addition of sat. aq. $\mathrm{NH}_{4} \mathrm{Cl}(8 \mathrm{~mL})$, diluted with EtOAc $(8 \mathrm{~mL})$, and the organic phase was separated. The aqueous phase was extracted with EtOAc $(3 \times 8 \mathrm{~mL})$ and the combined organic layers were washed with brine $(20 \mathrm{~mL})$, dried over anhydrous $\mathrm{Na}_{2} \mathrm{SO}_{4}$, filtered, and concentrated under reduced pressure by rotary evaporation. Purification by flash column chromatography on silica gel (hexanes/Et $/ \mathrm{t}_{2} \mathrm{O}=$ $3: 1$ to $1: 2)$ afforded the title product as a yellow viscous oil $(38 \mathrm{mg}, 88 \%) . \mathbf{R}_{\mathbf{f}}=0.15$ (hexanes/ $\left.\mathrm{Et}_{2} \mathrm{O}=1: 2\right) ;{ }^{1} \mathbf{H}$ NMR (400 MHz, $\left.\mathrm{CDCl}_{3}\right): \delta 7.79(\mathrm{~d}, J=15.6 \mathrm{~Hz}, 1 \mathrm{H}), 7.52(\mathrm{~d}$, $J=7.6 \mathrm{~Hz}, 3 \mathrm{H}), 7.32-7.21(\mathrm{~m}, 11 \mathrm{H}), 6.83(\mathrm{~d}, J=15.2 \mathrm{~Hz}, 1 \mathrm{H}), 4.70(\mathrm{~s}, 2 \mathrm{H}), 4.60(\mathrm{~s}$, $2 \mathrm{H}), 1.30(\mathrm{~s}, 9 \mathrm{H}) ;{ }^{13} \mathrm{C}$ NMR $\left(100 \mathrm{MHz}, \mathrm{CDCl}_{3}\right): \delta 176.8,167.4,143.4,139.6,137.4$, 136.8, 130.9, 129.1, 128.8, 128.7, 128.4, 127.8, 127.5, 126.7, 119.9, 116.0, 50.2, 48.9, 39.8, 27.8; IR $\left(\mathrm{cm}^{-1}\right): 3325,2969,1644,1587,1513,1467,1408,1314,1207,981,829$, 700; ESI-HRMS (m/z): [M+H] $]^{+}$calc'd for $\mathrm{C}_{28} \mathrm{H}_{31} \mathrm{~N}_{2} \mathrm{O}_{2}: 427.2381$; found: 427.2365 . 


\section{Amide 2ad}

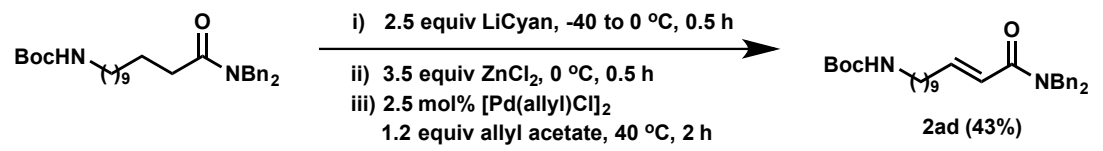

To a $-40{ }^{\circ} \mathrm{C}$ solution of $N$-cyclohexyl-2,6-diisopropylaniline $(130 \mathrm{mg}, 0.50 \mathrm{mmol}$, 2.5 equiv) in THF (3.0 mL, $0.17 \mathrm{M})$ was added $n$-BuLi (2.5 M in hexanes, $0.20 \mathrm{~mL}, 0.50$ mmol, 2.5 equiv). After 3-5 mins, the reaction mixture became cloudy, and was stirred for $1 \mathrm{~h}$. Amide 1ad (99 mg, $0.2 \mathrm{mmol}, 1.0$ equiv) was added dropwise into the reaction mixture and the mixture became clear immediately. The resulting solution was moved into an ice-water bath and stirred for $30 \mathrm{~min}$. $\mathrm{ZnCl}_{2}(0.5 \mathrm{M}$ in THF, $1.4 \mathrm{~mL}, 0.7 \mathrm{mmol}$, 3.5 equiv) was added and stirred for $30 \mathrm{~min}$. The stock solution of [Pd(allyl)Cl $]_{2}(1.8 \mathrm{mg}$, $0.005 \mathrm{mmol}, 0.025$ equiv) and allyl acetate (24 mg, $0.24 \mathrm{mmol}, 1.2$ equiv) in THF (0.20 $\mathrm{mL}$ ) was next added at the same temperature. The reaction mixture was placed into a preheated $40{ }^{\circ} \mathrm{C}$ oil bath and stirred for $2 \mathrm{~h}$. The resulting mixture was cooled to room temperature and stopped with the addition of sat. aq. $\mathrm{NH}_{4} \mathrm{Cl}(8 \mathrm{~mL})$, diluted with EtOAc $(8 \mathrm{~mL})$, and the organic phase was separated. The aqueous phase was extracted with EtOAc $(3 \times 8 \mathrm{~mL})$ and the combined organic layers were washed with brine $(20 \mathrm{~mL})$, dried over anhydrous $\mathrm{Na}_{2} \mathrm{SO}_{4}$, filtered, and concentrated under reduced pressure by rotary evaporation. Purification by flash column chromatography on silica gel (hexanes/EtOAc $=10: 1$ to $3: 1)$ afforded the title product as a yellow oil $(43 \mathrm{mg}, 43 \%) . \mathbf{R}_{\mathbf{f}}=0.28$ (hexanes/EtOAc = 3:1); ${ }^{1} \mathbf{H}$ NMR (400 MHz, $\left.\mathrm{CDCl}_{3}\right): \delta 7.36-7.15(\mathrm{~m}, 10 \mathrm{H}), 7.05$ (dt, $J=$ 14.8, 7.2 Hz, 1H), 6.25 (d, $J=14.8 \mathrm{~Hz}, 1 \mathrm{H}), 4.62$ (s, 2H), 4.55 (bs, 1H), 4.49 (s, 2H), $3.08(\mathrm{q}, J=6.0 \mathrm{~Hz}, 2 \mathrm{H}), 2.16(\mathrm{q}, J=7.2 \mathrm{~Hz}, 2 \mathrm{H}), 1.50-1.37(\mathrm{~m}, 4 \mathrm{H}), 1.43$ (s, 9H), 1.32$1.28(\mathrm{~m}, 10 \mathrm{H}) ;{ }^{13} \mathbf{C}$ NMR $\left(100 \mathrm{MHz}, \mathrm{CDCl}_{3}\right): \delta 167.4,156.0,148.1,137.4,136.7,128.9$, $128.5,128.3,127.6,127.3,126.5,120.0,79.1,49.8,48.4,40.6,32.5,30.0,29.4,29.3$, 29.2, 29.1, 28.4, 28.3, 26.7; IR ( $\left.\mathrm{cm}^{-1}\right): 3332,2929,2855,1708,1657,1618,1522,1495$, 1453, 1364, 1211, 1171, 978; ESI-HRMS (m/z): $[\mathrm{M}+\mathrm{H}]^{+}$calc'd for $\mathrm{C}_{31} \mathrm{H}_{45} \mathrm{~N}_{2} \mathrm{O}_{3}$ : 493.3425; found: 493.3426. 


\section{(E)-3-phenyl-1-(piperazin-1-yl)prop-2-en-1-one 2ae}

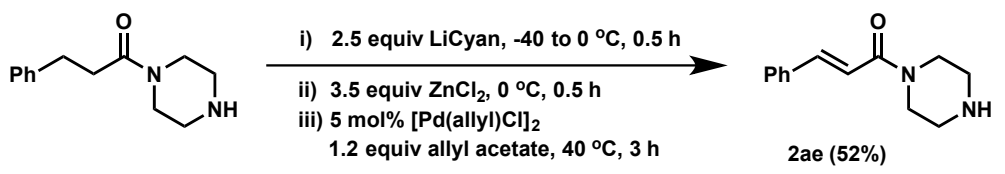

To a $-40{ }^{\circ} \mathrm{C}$ solution of $N$-cyclohexyl-2,6-diisopropylaniline $(65 \mathrm{mg}, 0.25 \mathrm{mmol}$, 2.5 equiv) in THF (2.0 mL, $0.13 \mathrm{M})$ was added $n$-BuLi (2.5 M in hexanes, $0.10 \mathrm{~mL}, 0.25$ mmol, 2.5 equiv). After 3-5 mins, the reaction mixture became cloudy, and was stirred for $1 \mathrm{~h}$. Amide 1ae (22 mg, $0.1 \mathrm{mmol}, 1.0$ equiv) was added dropwise into the reaction mixture and the mixture became clear immediately. The resulting solution was moved into an ice-water bath and stirred for $30 \mathrm{~min}$. $\mathrm{ZnCl}_{2}(0.5 \mathrm{M}$ in THF, $0.7 \mathrm{~mL}, 0.35 \mathrm{mmol}$, 3.5 equiv) was added and stirred for $30 \mathrm{~min}$. The stock solution of $\left[\mathrm{Pd}(\right.$ allyl $) \mathrm{Cl}_{2}(1.8 \mathrm{mg}$, $0.005 \mathrm{mmol}, 0.05$ equiv) and allyl acetate (12 mg, $0.12 \mathrm{mmol}, 1.2$ equiv) in THF (0.10 $\mathrm{mL}$ ) was next added at the same temperature. The reaction mixture was placed into a preheated $40{ }^{\circ} \mathrm{C}$ oil bath and stirred for $3 \mathrm{~h}$. The resulting mixture was cooled to room temperature and stopped with the addition of sat. aq. $\mathrm{NaHCO}_{3}(8 \mathrm{~mL})$, diluted with EtOAc $(8 \mathrm{~mL})$, and the organic phase was separated. The aqueous phase was extracted with EtOAc $(3 \times 8 \mathrm{~mL})$ and the combined organic layers were washed with brine $(20$ $\mathrm{mL}$ ), dried over anhydrous $\mathrm{Na}_{2} \mathrm{SO}_{4}$, filtered, and concentrated under reduced pressure by rotary evaporation. Purification by flash column chromatography on silica gel (DCM/MeOH/ $\mathrm{Et}_{3} \mathrm{~N}=100: 0: 1$ to $\left.100: 33: 1\right)$ afforded the title product as a yellow oil (13 $\mathrm{mg}$ ). The material thus obtained contains $10 \%$ of starting material amide lae as an inseparable mixture. Based on the observed $90 \%$ purity, the calculated yield of $2 \mathrm{am}$ is $52 \% . \mathbf{R}_{\mathbf{f}}=0.50(\mathrm{DCM} / \mathrm{MeOH}=5: 1) ;{ }^{1} \mathbf{H} \mathbf{~ N M R}\left(600 \mathrm{MHz}, \mathrm{CDCl}_{3}\right): \delta 7.76(\mathrm{~d}, J=15.6$ $\mathrm{Hz}, 1 \mathrm{H}), 7.51(\mathrm{~d}, J=7.2 \mathrm{~Hz}, 2 \mathrm{H}), 7.38-7.34(\mathrm{~m}, 3 \mathrm{H}), 6.86(\mathrm{~d}, J=15.0 \mathrm{~Hz}, 1 \mathrm{H}), 3.71$ (bs, 2H), 3.64 (bs, 2H), 2.90 (bs, 3H), 2.13 (bs, 2H); ${ }^{13} \mathbf{C}$ NMR (150 MHz, $\left.\mathrm{CDCl}_{3}\right): \delta$ 165.6, $142.9,135.4,129.7,128.9,127.8,117.2,47.1,46.6,45.9,43.3 ;$ IR $\left(\mathrm{cm}^{-1}\right): 3107,2868$, 1647, 1596, 1457, 1158, 1081, 821; ESI-HRMS (m/z): [M+H $]^{+}$calc'd for $\mathrm{C}_{13} \mathrm{H}_{17} \mathrm{~N}_{2} \mathrm{O}$ : 217.1337; found: 217.1311. 
Amide 2af

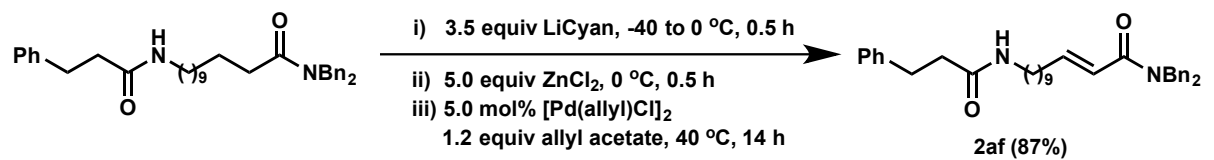

To a $-40{ }^{\circ} \mathrm{C}$ solution of $N$-cyclohexyl-2,6-diisopropylaniline $(91 \mathrm{mg}, 0.35 \mathrm{mmol}$, 3.5 equiv) in THF (2.0 mL, $0.18 \mathrm{M})$ was added $n$-BuLi (2.5 M in hexanes, $0.14 \mathrm{~mL}, 0.35$ mmol, 3.5 equiv). After 3-5 mins, the reaction mixture became cloudy, and was stirred for $1 \mathrm{~h}$. Amide $1 \mathrm{af}(53 \mathrm{mg}, 0.10 \mathrm{mmol}, 1.0$ equiv) was added dropwise into the reaction mixture and the mixture became clear immediately. The resulting solution was moved into an ice-water bath and stirred for $30 \mathrm{~min}$. $\mathrm{ZnCl}_{2}(0.5 \mathrm{M}$ in THF, $1.0 \mathrm{~mL}, 0.50 \mathrm{mmol}$, 5.0 equiv) was added and stirred for $30 \mathrm{~min}$. The stock solution of $[\mathrm{Pd}(\text { allyl }) \mathrm{Cl}]_{2}(1.8 \mathrm{mg}$, $0.005 \mathrm{mmol}, 0.05$ equiv) and allyl acetate (12 $\mathrm{mg}, 0.12 \mathrm{mmol}, 1.2$ equiv) in THF (0.10 $\mathrm{mL}$ ) was next added at the same temperature. The reaction mixture was placed into a preheated $40{ }^{\circ} \mathrm{C}$ oil bath and stirred for $12 \mathrm{~h}$. The resulting mixture was cooled to room temperature and stopped with the addition of sat. aq. $\mathrm{NH}_{4} \mathrm{Cl}(8 \mathrm{~mL})$, diluted with EtOAc $(8 \mathrm{~mL})$, and the organic phase was separated. The aqueous phase was extracted with EtOAc $(3 \times 8 \mathrm{~mL})$ and the combined organic layers were washed with brine $(20 \mathrm{~mL})$, dried over anhydrous $\mathrm{Na}_{2} \mathrm{SO}_{4}$, filtered, and concentrated under reduced pressure by rotary evaporation. Purification by flash column chromatography on silica gel (hexanes/EtOAc $=3: 1$ to $1: 1)$ afforded the title product as a white solid (46 mg, 87\%). M.P.: $72-73{ }^{\circ} \mathrm{C} ; \mathbf{R}_{\mathbf{f}}$ $=0.26($ hexanes $/$ EtOAc $=1: 1) ;{ }^{1} \mathbf{H}$ NMR $\left(400 \mathrm{MHz}, \mathrm{CDCl}_{3}\right): \delta 7.37-7.15(\mathrm{~m}, 15 \mathrm{H}), 7.04$ (dt, $J=14.8,7.2 \mathrm{~Hz}, 1 \mathrm{H}), 6.26$ (d, $J=14.8 \mathrm{~Hz}, 1 \mathrm{H}), 5.64$ (s, 1H), 4.62 (s, 2H), 4.49 (s, 2H), $3.17(\mathrm{q}, J=7.6 \mathrm{~Hz}, 2 \mathrm{H}), 2.94(\mathrm{t}, J=8.0 \mathrm{~Hz}, 2 \mathrm{H}), 2.45(\mathrm{t}, J=7.6 \mathrm{~Hz}, 2 \mathrm{H}), 2.16(\mathrm{q}, J$ $=7.2 \mathrm{~Hz}, 2 \mathrm{H}), 1.42-1.37(\mathrm{~m}, 4 \mathrm{H}), 1.24-1.21(\mathrm{~m}, 10 \mathrm{H}) ;{ }^{13} \mathbf{C} \mathbf{N M R}\left(100 \mathrm{MHz}, \mathrm{CDCl}_{3}\right): \delta$ $172.1,167.5,148.2,141.0,137.4,136.8,128.9,128.6,128.5,128.4,128.4,127.7,127.4$, 126.6, 120.1, 49.9, 48.5, 39.6, 38.6, 32.6, 31.9, 29.6, 29.4, 29.4, 29.3, 29.2 28.4, 26.9; IR $\left(\mathrm{cm}^{-1}\right): 2925,2852,1661,1632,1544,1442,1324,1158,1080,796 ;$ ESI-HRMS (m/z): $[\mathrm{M}+\mathrm{H}]^{+}$calc'd for $\mathrm{C}_{35} \mathrm{H}_{45} \mathrm{~N}_{2} \mathrm{O}_{2}$ : 525.3476; found: 525.3452 . 


\section{Amide 2ag}

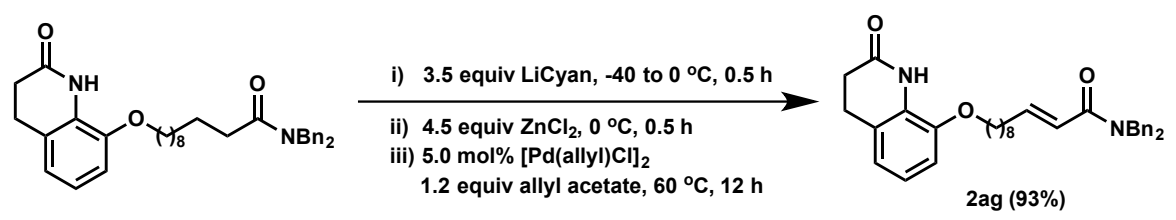

To a $-40{ }^{\circ} \mathrm{C}$ solution of $N$-cyclohexyl-2,6-diisopropylaniline $(91 \mathrm{mg}, 0.35 \mathrm{mmol}$, 3.5 equiv) in THF ( $2.0 \mathrm{~mL}, 0.18 \mathrm{M})$ was added $n-\mathrm{BuLi}(2.5 \mathrm{M}$ in hexanes, $0.14 \mathrm{~mL}, 0.35$ mmol, 3.5 equiv). After 3-5 mins, the reaction mixture became cloudy, and was stirred for $1 \mathrm{~h}$. Amide $1 \mathrm{ag}$ (53 mg, $0.10 \mathrm{mmol}, 1.0$ equiv) was added dropwise into the reaction mixture and the mixture became clear immediately. The resulting solution was moved into an ice-water bath and stirred for $30 \mathrm{~min} . \mathrm{ZnCl}_{2}(0.5 \mathrm{M}$ in THF, $0.9 \mathrm{~mL}, 0.45 \mathrm{mmol}$, 4.5 equiv) was added and stirred for $30 \mathrm{~min}$. The stock solution of $[\mathrm{Pd}(\text { allyl }) \mathrm{Cl}]_{2}(1.8 \mathrm{mg}$, $0.005 \mathrm{mmol}, 0.05$ equiv) and allyl acetate $(12 \mathrm{mg}, 0.12 \mathrm{mmol}, 1.2$ equiv) in THF ( 0.10 $\mathrm{mL}$ ) was next added at the same temperature. The reaction mixture was placed into a preheated $60{ }^{\circ} \mathrm{C}$ oil bath and stirred for $12 \mathrm{~h}$. The resulting mixture was cooled to room temperature and stopped with the addition of sat. aq. $\mathrm{NH}_{4} \mathrm{Cl}(8 \mathrm{~mL})$, diluted with EtOAc $(8 \mathrm{~mL})$, and the organic phase was separated. The aqueous phase was extracted with EtOAc $(3 \times 8 \mathrm{~mL})$ and the combined organic layers were washed with brine $(20 \mathrm{~mL})$, dried over anhydrous $\mathrm{Na}_{2} \mathrm{SO}_{4}$, filtered, and concentrated under reduced pressure by rotary evaporation. Purification by flash column chromatography on silica gel (hexanes/acetone $=12: 1$ to $2: 1)$ afforded the title product as a viscous yellow oil (49 $\mathrm{mg}, 93 \%) . \mathbf{R}_{\mathbf{f}}=0.22$ (hexanes/EtOAc $=2: 1) ;{ }^{1} \mathbf{H}$ NMR $\left(400 \mathrm{MHz}, \mathrm{CDCl}_{3}\right): \delta 8.90(\mathrm{~s}, 1 \mathrm{H}), 7.37-7.24(\mathrm{~m}, 8 \mathrm{H})$, $7.17(\mathrm{~d}, J=7.2 \mathrm{~Hz}, 2 \mathrm{H}), 7.07$ (dt, $J=15.2,7.6 \mathrm{~Hz}, 1 \mathrm{H}), 7.02$ (d, $J=8.0 \mathrm{~Hz}, 1 \mathrm{H}), 6.51$ (dd, $J=8.0,2.4 \mathrm{~Hz}, 1 \mathrm{H}), 6.39$ (d, $J=2.8 \mathrm{~Hz}, 1 \mathrm{H}), 6.27$ (d, $J=14.8 \mathrm{~Hz}, 1 \mathrm{H}), 4.64(\mathrm{~s}, 2 \mathrm{H})$, 4.51 (s, 2H), 3.90 (t, $J=6.8 \mathrm{~Hz}, 2 \mathrm{H}), 2.88(\mathrm{t}, J=7.6 \mathrm{~Hz}, 2 \mathrm{H}), 2.60(\mathrm{t}, J=7.2 \mathrm{~Hz}, 2 \mathrm{H})$, 2.18 (q, $J=6.8 \mathrm{~Hz}, 2 \mathrm{H}), 1.73$ (quint, $J=8.0 \mathrm{~Hz}, 2 \mathrm{H}$ ), $1.42-1.29$ (m, 10H); ${ }^{13} \mathbf{C}$ NMR (100 MHz, $\left.\mathrm{CDCl}_{3}\right): \delta 172.3,167.5,158.8,148.2,138.3,137.5,136.8,129.0,128.6$, 128.6, 128.4, 127.7, 127.4, 126.6, 120.1, 115.6, 108.7, 102.4, 68.2, 49.9, 48.6, 32.6, 31.2, 29.3, 29.3, 29.3, 29.1, 28.4, 26.0, 24.7; IR $\left(\mathrm{cm}^{-1}\right): 2928,2855,1680,1657,1623,1593$, 1519, 1360, 1188, 1168, 1027, 733; ESI-HRMS (m/z): $[\mathrm{M}+\mathrm{H}]^{+}$calc'd for $\mathrm{C}_{34} \mathrm{H}_{41} \mathrm{~N}_{2} \mathrm{O}_{3}$ : 525.3112; found: 525.3140 . 


\section{Amide 2ah}

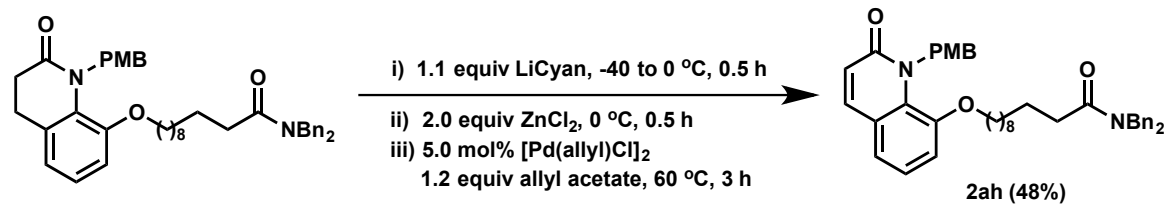

To a $-40{ }^{\circ} \mathrm{C}$ solution of $\mathrm{N}$-cyclohexyl-2,6-diisopropylaniline $(57 \mathrm{mg}, 0.22 \mathrm{mmol}$, 1.1 equiv) in THF $(2.0 \mathrm{~mL}, 0.11 \mathrm{M})$ was added $n$-BuLi $(2.5 \mathrm{M}$ in hexanes, $0.090 \mathrm{~mL}$, $0.22 \mathrm{mmol}, 1.1$ equiv). After 3-5 mins, the reaction mixture became cloudy, and was stirred for $1 \mathrm{~h}$. Amide 1ah (129 mg, $0.20 \mathrm{mmol}, 1.0$ equiv) was added dropwise into the reaction mixture and the mixture became clear immediately. The resulting solution was moved into an ice-water bath and stirred for $30 \mathrm{~min}$. $\mathrm{ZnCl}_{2}(0.5 \mathrm{M}$ in THF, $0.8 \mathrm{~mL}, 0.40$ mmol, 2.0 equiv) was added and stirred for $30 \mathrm{~min}$. The stock solution of $[\mathrm{Pd}(\text { allyl }) \mathrm{Cl}]_{2}$ (3.7 mg, $0.01 \mathrm{mmol}, 0.05$ equiv) and allyl acetate ( $24 \mathrm{mg}, 0.24 \mathrm{mmol}, 1.2$ equiv) in THF $(0.10 \mathrm{~mL})$ was next added at the same temperature. The reaction mixture was placed into a preheated $60{ }^{\circ} \mathrm{C}$ oil bath and stirred for $3 \mathrm{~h}$. The resulting mixture was cooled to room temperature and stopped with the addition of sat. aq. $\mathrm{NH}_{4} \mathrm{Cl}(8 \mathrm{~mL})$, diluted with EtOAc $(8 \mathrm{~mL})$, and the organic phase was separated. The aqueous phase was extracted with EtOAc $(3 \times 8 \mathrm{~mL})$ and the combined organic layers were washed with brine $(20 \mathrm{~mL})$, dried over anhydrous $\mathrm{Na}_{2} \mathrm{SO}_{4}$, filtered, and concentrated under reduced pressure by rotary evaporation. Purification by flash column chromatography on silica gel (hexanes/EtOAc $=5: 1$ to $1: 1)$ afforded starting material $1 \mathbf{a h}(53 \mathrm{mg}, 41 \%)$ and the title product as a viscous yellow oil (62 mg, 48\%). $\mathbf{R}_{\mathbf{f}}=0.29$ (hexanes/EtOAc $\left.=1: 1\right) ;{ }^{1} \mathbf{H}$ NMR $(400 \mathrm{MHz}$, $\left.\mathrm{CDCl}_{3}\right): \delta 7.63(\mathrm{~d}, J=9.2 \mathrm{~Hz}, 1 \mathrm{H}), 7.42(\mathrm{~d}, J=8.8 \mathrm{~Hz}, 1 \mathrm{H}), 7.38-7.14(\mathrm{~m}, 12 \mathrm{H}), 6.83(\mathrm{~d}$, $J=8.0 \mathrm{~Hz}, 2 \mathrm{H}), 6.75(\mathrm{~d}, J=6.8 \mathrm{~Hz}, 1 \mathrm{H}), 6.74(\mathrm{~s}, 1 \mathrm{H}), 6.62$ (d, $J=9.2 \mathrm{~Hz}, 1 \mathrm{H}), 5.45$ (s, 2H), $4.61(\mathrm{~s}, 2 \mathrm{H}), 4.45(\mathrm{~s}, 2 \mathrm{H}), 3.89$ (t, $J=6.4 \mathrm{~Hz}, 2 \mathrm{H}), 3.74(\mathrm{~s}, 3 \mathrm{H}), 2.42$ (t, $J=7.6 \mathrm{~Hz}$, 2H), 1.72 (quint, $J=6.4 \mathrm{~Hz}, 4 \mathrm{H}), 1.46-1.22(\mathrm{~m}, 12 \mathrm{H}) ;{ }^{13} \mathbf{C}$ NMR (100 MHz, $\left.\mathrm{CDCl}_{3}\right): \delta$ $173.8,163.0,161.3,158.8,141.2,139.4,137.6,136.7,130.1,129.0,128.6,128.6,128.3$, 128.1, 127.6, 127.4, 126.4, 118.3, 115.0, 114.2, 110.6, 100.0, 68.3, 55.3, 50.0, 48.1, 45.6, 33.3, 29.6, 29.5, 29.5, 29.4, 29.1, 26.0, 25.5; IR ( $\left.\mathrm{cm}^{-1}\right):$ 2928, 2855, 1649, 1619 1590, 1512, 1441, 1246, 1225, 1175, 1028, 836; ESI-HRMS $(\mathrm{m} / \mathrm{z}):[\mathrm{M}+\mathrm{H}]^{+}$calc'd for $\mathrm{C}_{42} \mathrm{H}_{49} \mathrm{~N}_{2} \mathrm{O}_{4}$ : 645.3687; found: 645.3684 . 
$\mathrm{N}, \mathrm{N}$-dibenzyl-3-phenylbut-2-enamide 2ai

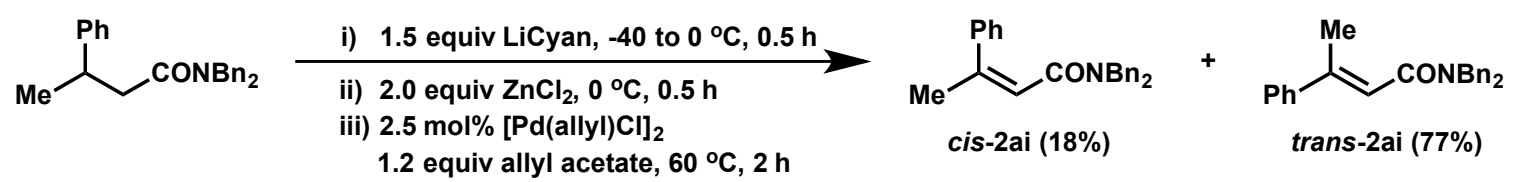

To a $-40{ }^{\circ} \mathrm{C}$ solution of $N$-cyclohexyl-2,6-diisopropylaniline (194 $\mathrm{mg}, 0.75 \mathrm{mmol}$, 1.5 equiv) in THF ( $3.0 \mathrm{~mL}, 0.25 \mathrm{M})$ was added $n$-BuLi ( $2.5 \mathrm{M}$ in hexanes, $0.30 \mathrm{~mL}, 0.75$ mmol, 1.5 equiv). After 3 5 mins, the resulting solution became cloudy, was stirred for 1 h. Amide 1ai (172 mg, $0.50 \mathrm{mmol}, 1.0$ equiv) was added dropwise into the resulting solution. The reaction mixture was moved into an ice-water bath and stirred for $30 \mathrm{~min}$. $\mathrm{ZnCl}_{2}$ (0.5 M in THF, $2.0 \mathrm{~mL}, 1.0 \mathrm{mmol}, 2.0$ equiv) was added and stirred for $30 \mathrm{~min}$. The stock solution of $[\mathrm{Pd}(\text { allyl }) \mathrm{Cl}]_{2}(4.6 \mathrm{mg}, 0.0125 \mathrm{mmol}, 0.025$ equiv $)$ and allyl acetate (60 mg, $0.60 \mathrm{mmol}, 1.2$ equiv) in THF $(0.5 \mathrm{~mL})$ was next added at the same temperature. The reaction mixture was placed into a preheated $60-{ }^{\circ} \mathrm{C}$ oil bath and stirred for $2 \mathrm{~h}$. The resulting mixture was cooled to room temperature and stopped with addition of sat. aq. $\mathrm{NH}_{4} \mathrm{Cl}(8 \mathrm{~mL})$, diluted with EtOAc $(8 \mathrm{~mL})$, and the organic phase was separated. The aqueous phase was extracted with EtOAc $(3 \times 8 \mathrm{~mL})$ and the combined organic layers were washed with brine $(20 \mathrm{~mL})$, dried over anhydrous $\mathrm{Na}_{2} \mathrm{SO}_{4}$, filtered, and concentrated under reduced pressure by rotary evaporation. Purification by flash column chromatography on silica gel (hexanes/EtOAc $=10: 1$ to 3:1) afforded trans-2ai as an off white solid (132 mg, 77\%) and cis-2ai as a viscous yellow oil (31.7 mg, 18\%). $\mathbf{R}_{\mathbf{f}}=0.33$ (hexanes/EtOAc $=4: 1)$;

The spectra data of trans-2ai: ${ }^{1} \mathbf{H}$ NMR $\left(400 \mathrm{MHz}, \mathrm{CDCl}_{3}\right): \delta 7.43-7.33(\mathrm{~m}, 13 \mathrm{H}), 7.22$ (d, $J=7.2 \mathrm{~Hz}, 2 \mathrm{H}), 6.46$ (q, $J=0.8 \mathrm{~Hz}, 1 \mathrm{H}), 4.71$ (s, 2H), $4.56(\mathrm{~s}, 2 \mathrm{H}), 2.46$ (d, $J=0.8$ $\mathrm{Hz}, 3 \mathrm{H}) ;{ }^{13} \mathbf{C}$ NMR $\left(100 \mathrm{MHz}, \mathrm{CDCl}_{3}\right): \delta 168.8,147.6,142.0,137.4,136.6,129.0,128.7$, 128.5, 128.4, 127.7, 127.5, 126.9, 126.1, 119.5, 50.6, 47.4, 18.3; IR $\left(\mathrm{cm}^{-1}\right): 2923,1629$, 1606, 1494, 1440, 1197, 972, 762; ESI-HRMS (m/z): $[\mathrm{M}+\mathrm{H}]^{+}$calc'd for $\mathrm{C}_{24} \mathrm{H}_{24} \mathrm{NO}$ : 342.1858; found: 342.1856 .

The spectra data of cis-2ai: ${ }^{1} \mathbf{H}$ NMR $\left(600 \mathrm{MHz}, \mathrm{CDCl}_{3}\right): \delta 7.33-7.28(\mathrm{~m}, 8 \mathrm{H}), 7.22-7.21$ (m, 3H), 7.02 (d, $J=7.2 \mathrm{~Hz}, 2 \mathrm{H}), 6.92(\mathrm{~d}, J=7.2 \mathrm{~Hz}, 2 \mathrm{H}), 6.11(\mathrm{~s}, 1 \mathrm{H}), 4.45(\mathrm{~s}, 2 \mathrm{H})$, 4.29 (s, 2H), 2.15 (s, 3H); ${ }^{13} \mathbf{C}$ NMR $\left(150 \mathrm{MHz}, \mathrm{CDCl}_{3}\right): \delta 169.4,143.9,140.3,136.8$, $136.7,128.9,128.6,128.6,128.5,128.1,127.7,127.4,127.3,127.2,121.0,50.6,46.5$, 
25.1; IR $\left(\mathrm{cm}^{-1}\right):$ 2923, 1629, 1494, 1460, 1196, 1075, 782, 697; ESI-HRMS (m/z): $[\mathrm{M}+\mathrm{H}]^{+}$calc'd for $\mathrm{C}_{24} \mathrm{H}_{24} \mathrm{NO}$ : 342.1858 ; found: 342.1877 . 


\section{Cyclohex-1-ene-1-carbonitrile}

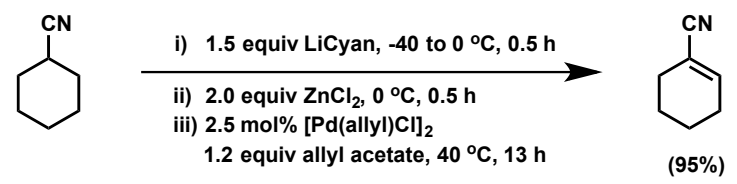

To a $-40{ }^{\circ} \mathrm{C}$ solution of $\mathrm{N}$-cyclohexyl-2,6-diisopropylaniline $(78 \mathrm{mg}, 0.30 \mathrm{mmol}$, 1.5equiv) in THF (2.0 mL, $0.15 \mathrm{M})$ was added $n$-BuLi $(2.5 \mathrm{M}$ in hexanes, $0.12 \mathrm{~mL}, 0.30$ mmol, 1.2 equiv). After 3 5 mins, the resulting solution became cloudy, was stirred for 1 h. Nitrile (22 mg, $0.20 \mathrm{mmol}, 1.0$ equiv) was added dropwise into the resulting solution. The reaction mixture was moved into an ice-water bath and stirred for $30 \mathrm{~min} . \mathrm{ZnCl}_{2}(0.5$ $\mathrm{M}$ in THF, $0.8 \mathrm{~mL}, 0.4 \mathrm{mmol}, 2.0$ equiv) was added and stirred for $30 \mathrm{~min}$. The stock solution of $[\mathrm{Pd}(\mathrm{allyl}) \mathrm{Cl}]_{2}(1.8 \mathrm{mg}, 0.0050 \mathrm{mmol}, 0.025$ equiv $)$ and allyl acetate $(24 \mathrm{mg}$, $0.24 \mathrm{mmol}, 1.2$ equiv) in THF $(0.20 \mathrm{~mL})$ was next added at the same temperature. The reaction mixture was placed into a preheated $40-{ }^{\circ} \mathrm{C}$ oil bath and stirred for $13 \mathrm{~h}$. The resulting mixture was cooled to room temperature and stopped with addition of sat. aq. $\mathrm{NH}_{4} \mathrm{Cl}(8 \mathrm{~mL})$, and 1,3,5-trimethoxybenzene (11.2 $\mathrm{mg}$ in $\left.1 \mathrm{~mL} \mathrm{THF}\right)$, diluted with EtOAc $(8 \mathrm{~mL})$, and the organic phase was separated. The aqueous phase was extracted with EtOAc $(3 \times 8 \mathrm{~mL})$ and the combined organic layers were washed with brine (20 $\mathrm{mL}$ ), dried over anhydrous $\mathrm{Na}_{2} \mathrm{SO}_{4}$, filtered, and concentrated under reduced pressure by rotary evaporation. The ${ }^{1} \mathrm{H}-\mathrm{NMR}$ yield of cyclohex-1-ene-1-carbonitrile was $95 \%$. 
tert-Butyl cinnamate

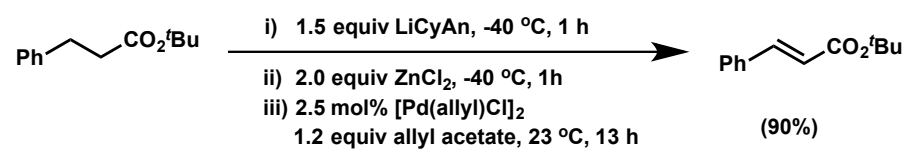

To a $-40{ }^{\circ} \mathrm{C}$ solution of $\mathrm{N}$-cyclohexyl-2,6-diisopropylaniline $(78 \mathrm{mg}, 0.30 \mathrm{mmol}$, 1.5equiv) in THF (2.0 mL, $0.15 \mathrm{M})$ was added $n$-BuLi $(2.5 \mathrm{M}$ in hexanes, $0.12 \mathrm{~mL}, 0.30$ mmol, 1.2 equiv). After 3 5 mins, the resulting solution became cloudy, was stirred for 1 h. Ester (42 mg, $0.20 \mathrm{mmol}, 1.0$ equiv) was added dropwise into the resulting solution, which was stirred for $1 \mathrm{~h}$ at the same temperature. $\mathrm{ZnCl}_{2}(0.5 \mathrm{M}$ in THF, $0.8 \mathrm{~mL}, 0.4$ mmol, 2.0 equiv) was added and stirred for $1 \mathrm{~h}$ at $-40{ }^{\circ} \mathrm{C}$. The stock solution of $[\mathrm{Pd}(\text { allyl }) \mathrm{Cl}]_{2}(1.8 \mathrm{mg}, 0.0050 \mathrm{mmol}, 0.025$ equiv) and allyl acetate $(24 \mathrm{mg}, 0.24 \mathrm{mmol}$, 1.2 equiv) in THF $(0.20 \mathrm{~mL})$ was next added at the same temperature. After stirring for $13 \mathrm{~h}$ at $23{ }^{\circ} \mathrm{C}$, the mixture was stopped by addition of sat. aq. $\mathrm{NH}_{4} \mathrm{Cl}(8 \mathrm{~mL})$, and $1,3,5-$ trimethoxybenzene (11.2 $\mathrm{mg}$ in $1 \mathrm{~mL} \mathrm{THF})$, diluted with EtOAc $(8 \mathrm{~mL})$, and the organic phase was separated. The aqueous phase was extracted with EtOAc $(3 \times 8 \mathrm{~mL})$ and the combined organic layers were washed with brine $(20 \mathrm{~mL})$, dried over anhydrous $\mathrm{Na}_{2} \mathrm{SO}_{4}$, filtered, and concentrated under reduced pressure by rotary evaporation. A ${ }^{1} \mathrm{H}-\mathrm{NMR}$ yield was obtained using 1,3,5-trimethoxybenzene as an internal standard. The ${ }^{1} \mathrm{H}-\mathrm{NMR}$ yield of tert-butyl cinnamate was $90 \%$. 


\section{References:}

${ }^{1}$ Drummond, L. J.; Sutherland, A. Tetrahedron 2010, 66, 5349.

${ }^{2}$ Evans, D. A.; Britton, T. C.; Dorow, R. L.; Dellaria, J. F. Tetrahedron 1988, 44, 5525.

${ }^{3}$ Weitgenant, J. A.; Katsuyama, I.; Bigi, M. A.; Corden, S. J.; Markiewicz, J. T.; Zabell, A. P. R.; Homan, K. T.; Wiest, O.; Stauffacher, C. V. Heterocycles 2006, 70, 599.

${ }^{4}$ Aubé, J.; Milligan, G. L. J. Am. Chem. Soc. 1991, 113, 8965.

${ }^{5}$ Motiwala, H. F.; Fehl, C.; Li, S.-W.; Hirt, E.; Porubsky, P.; Aubé, J. J. Am. Chem. Soc. 2013, 135, 9000.

${ }^{6}$ Xu, G.; Micklatcher, M.; Silvestri, M. A.; Hartman, T. L.; Burrier, J.; Osterling, M. C.; Wargo, H.; Turpin, J. A.; Buckheit, Jr. R. W.; Cushman, M. J. Med. Chem. 2001, 44, 4092.

${ }^{7}$ Gerus, I. I.; Mironets, R. V.; Shaitanova, E. N.; Kukhar, V. P. J. Fluorine Chem. 2010, 131, 224.

${ }^{8}$ Ding, G.; Lu, B.; Li, Y.; Wan, J.; Zhang, Z.; Xie, X. Adv. Synth. Catal. 2015, 357, 1013.

${ }^{9}$ Myers, A. G.; Yang, B. H.; Chen, H.; McKinstry, L.; Kopecky, D. J.; Gleason, J. L. J. Am. Chem. Soc. 1997, 119, 6496.

${ }^{10}$ Yao, H.; Yamamoto, K. Chem. Asian. J. 2012, 7, 1542.

${ }^{11}$ Liu, B.; Fan, Y.; Gao, Y.; Sun, C.; Xu, C.; Zhu, J. J. Am. Chem. Soc. 2013, 135, 468.

${ }^{12}$ Fors, B. P.; Doolerweerdt, K.; Zeng, Q.; Buchwald, S. L. Tetrahedron 2009, 65, 6576.

${ }^{13}$ Forbes, C. C.; DiVittorio, K. M.; Smith, B. D. J. Am. Chem. Soc. 2006, 128, 9211.

${ }^{14}$ Teng, F.; Sun, S.; Jiang, Y.; Yu, J.-T.; Cheng, J. Chem. Commun. 2015, 51, 5902.

15 Thompson, S.; Hamilton, A. D. Org. Biomol. Chem. 2012, 10, 5780.

${ }^{16}$ Kanagaraj, K.; Pitchumani, K. Chem. Eur. J. 2013, 19, 14425.

${ }^{17}$ Erdbrink, H.; Peuser, I.; Gerling, U. I. M.; Lentz, D.; Koksch, B.; Czekelius, C. Org. Biomol. Chem. 2012, 10, 8583.

${ }^{18}$ Hirsch-Weil, D.; Abboud, K. A.; Hong, S. Chem. Commun. 2010, 46, 4625.

${ }^{19}$ Curti, C.; Ranieri, B.; Battistini, L.; Rassu, G.; Zambrano, V.; Pelosi, G.; Casiraghi, G.; Zanardi, F. Adv. Synth. Catal. 2010, 352, 2011. 

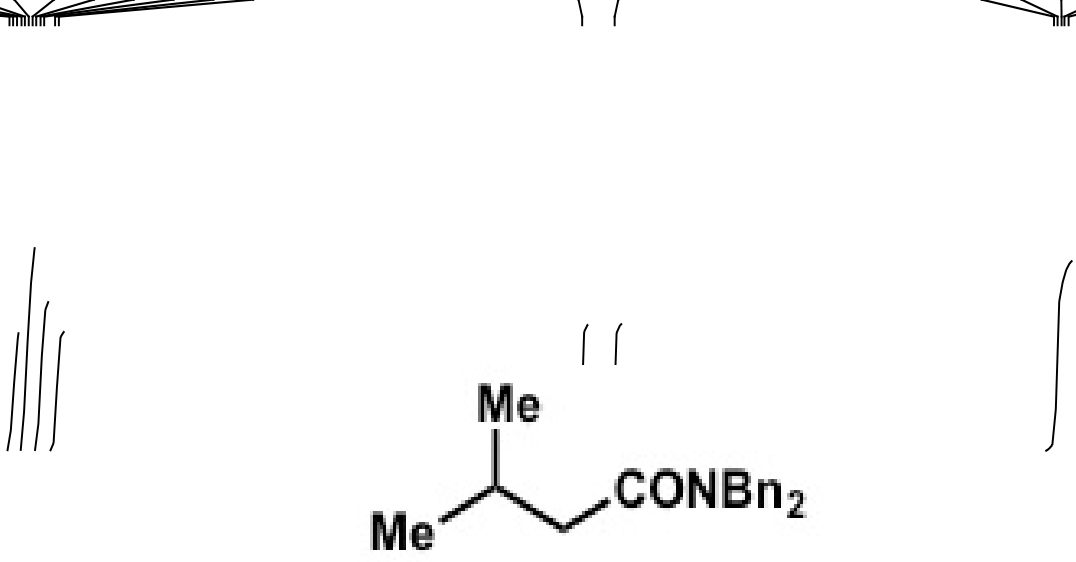

1a

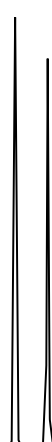

ताएका

舟

- $\dot{m} \sim \dot{\sim}$ 
<smiles>CCCCCCCCCC(=O)CC(C)C</smiles>

1a

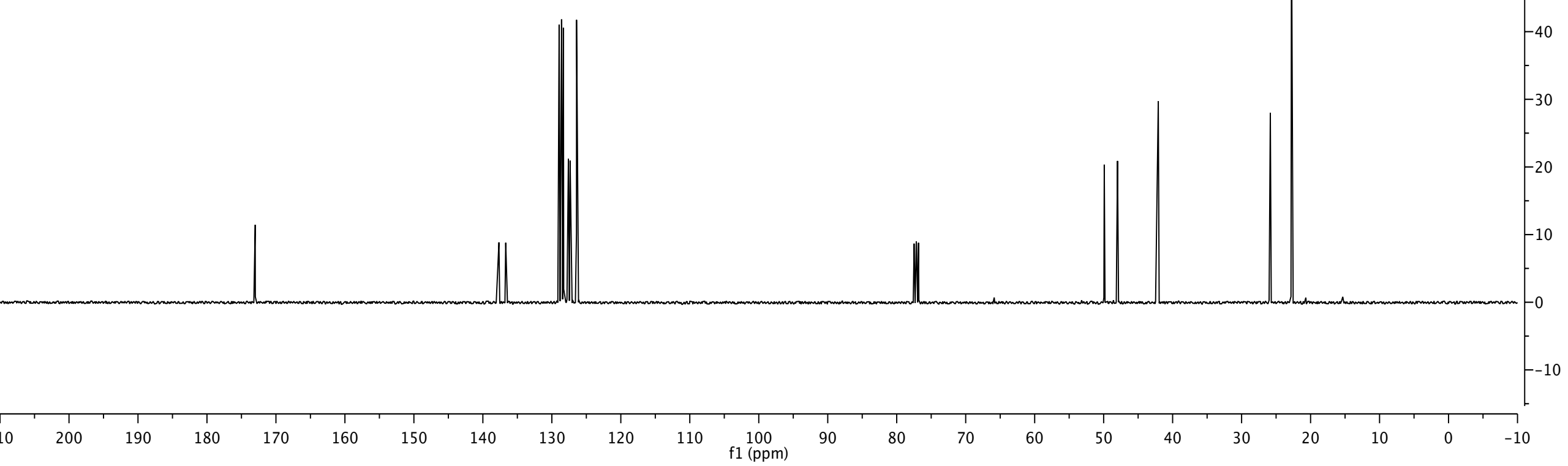




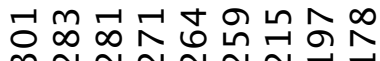
mกNNNN正

NNNNNNNN

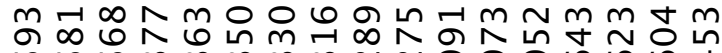

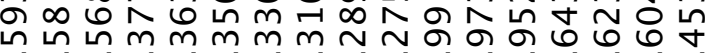

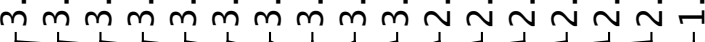

(1)<smiles>C=CC</smiles><smiles>CC(C)(C)OC(=O)N1CCN(C(=O)CCc2ccccc2)CC1</smiles>

1d

Boc
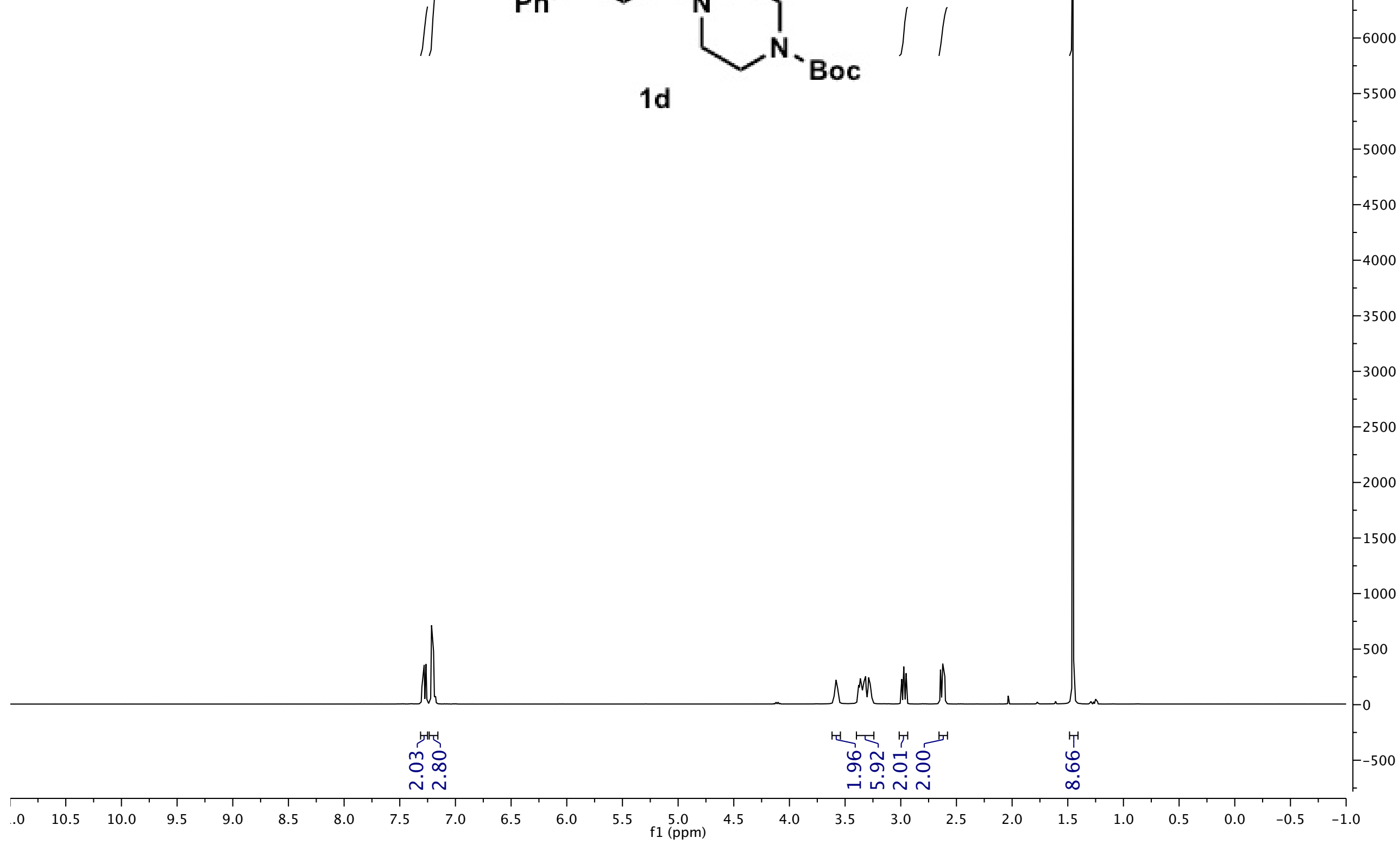


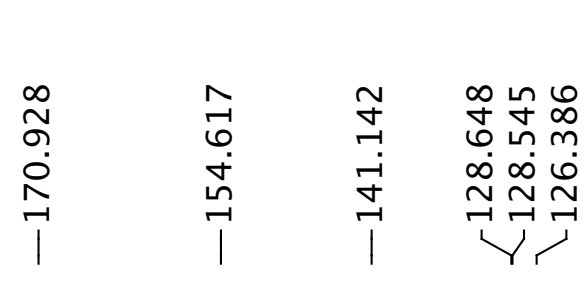

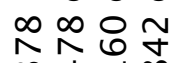

m.

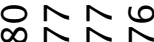

调

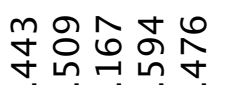

में

पर<smiles>CC(C)(C)OC(=O)N1CCN(C(=O)CCc2ccccc2)CC1</smiles>

1d

Boc 


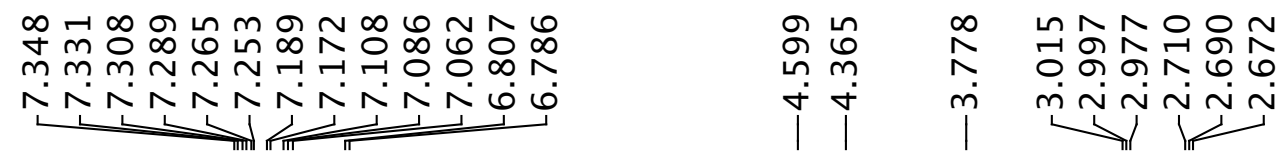

$-2600$
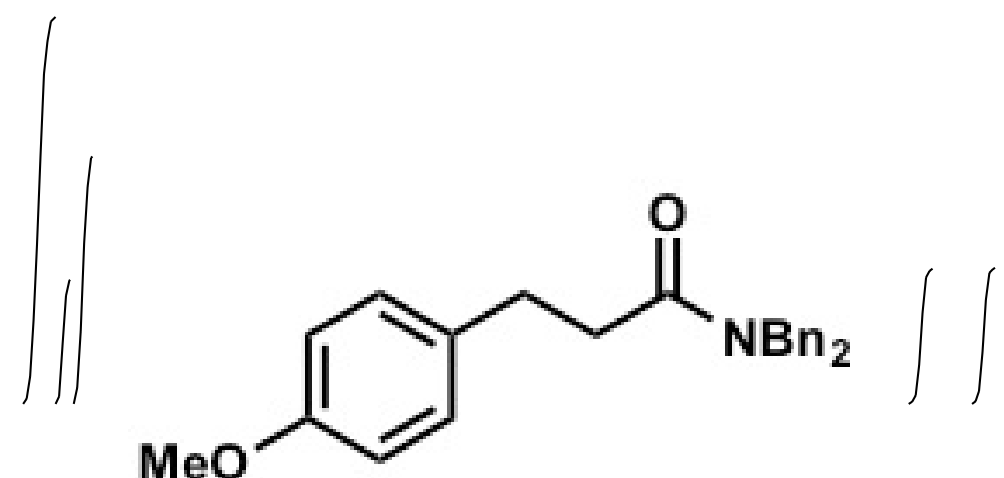

$1 f$

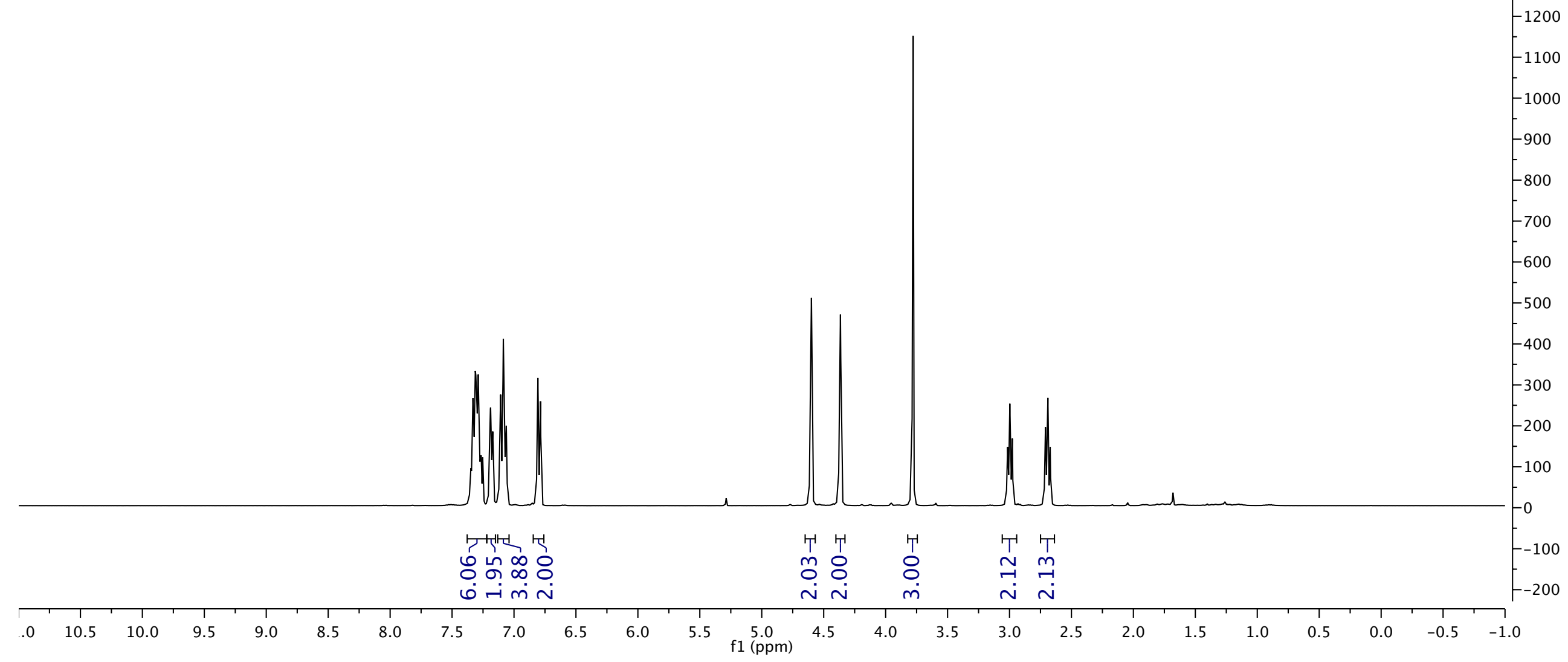


<smiles></smiles> 

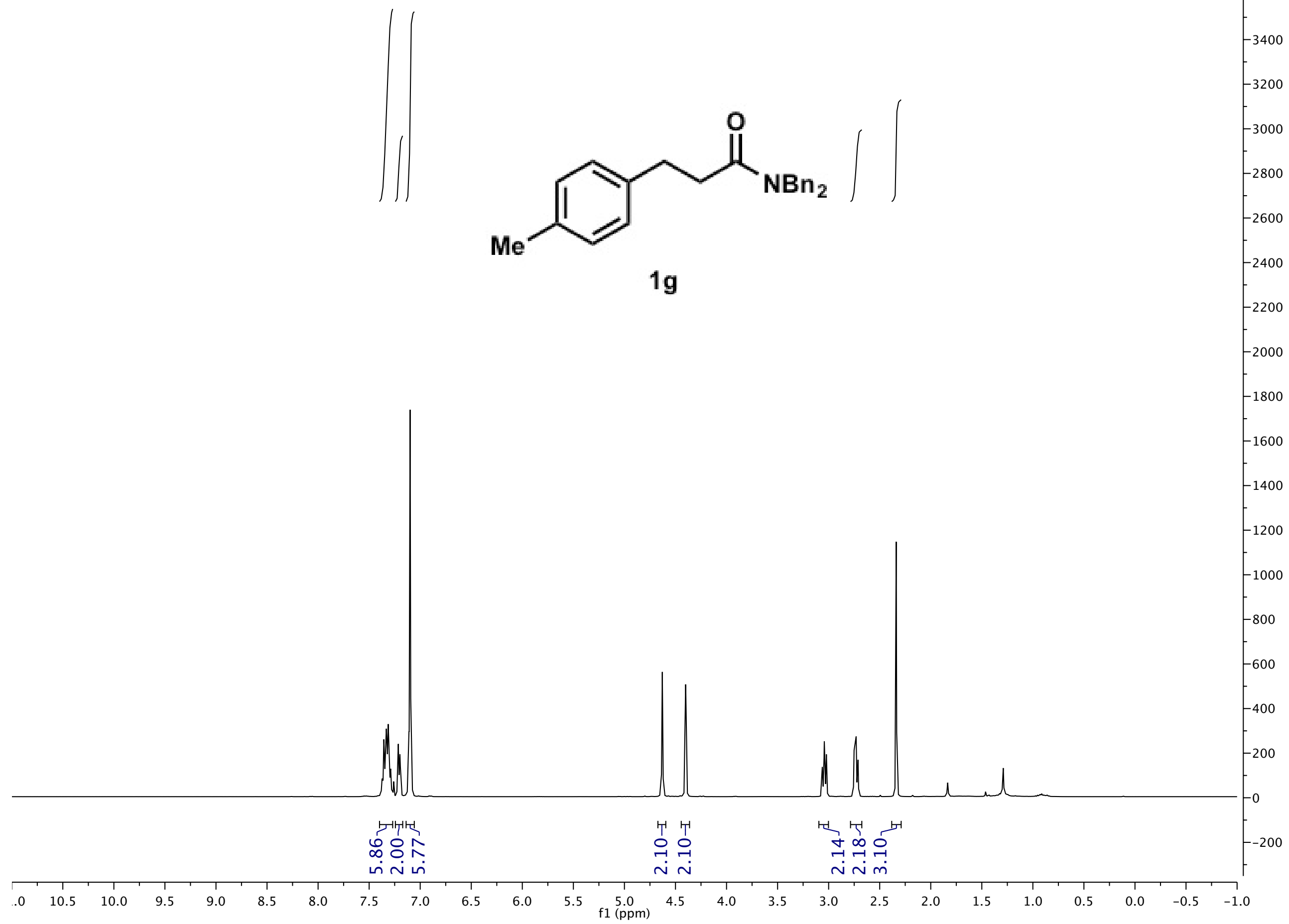
$\stackrel{\infty}{m} m$

? $m$<smiles>CCCCC(=O)CCc1ccc(C)cc1</smiles>

$1 \mathrm{~g}$

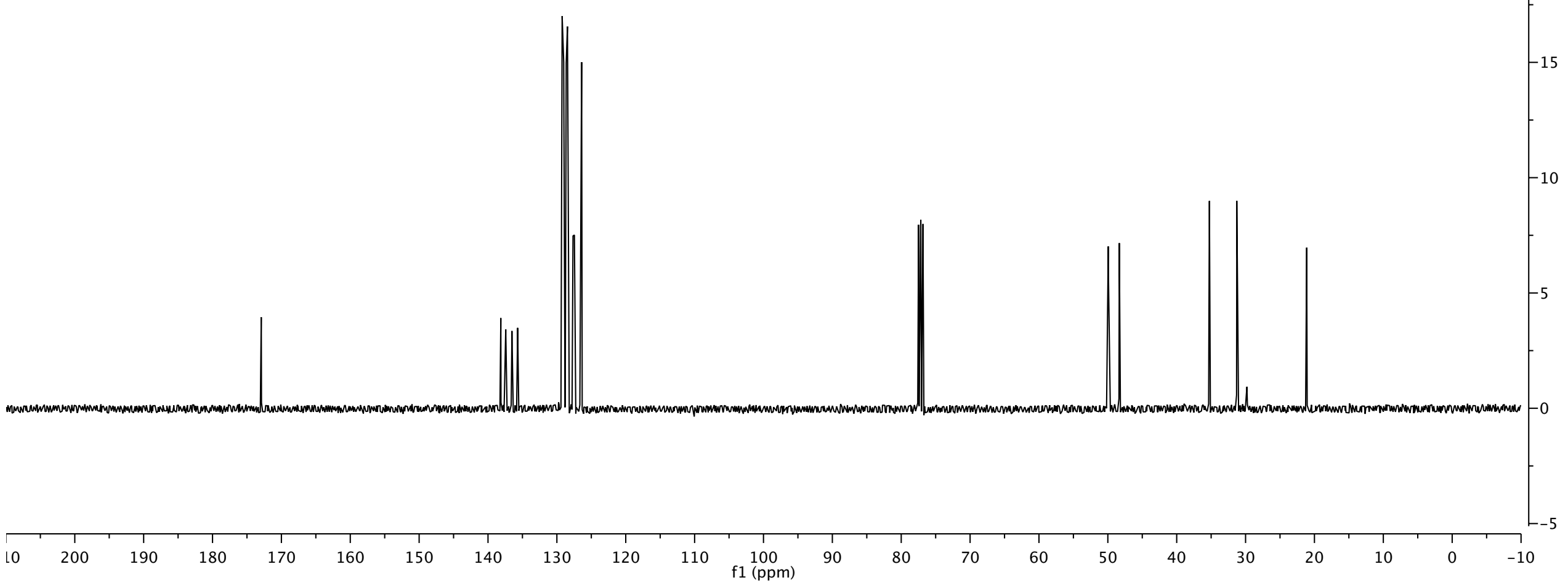



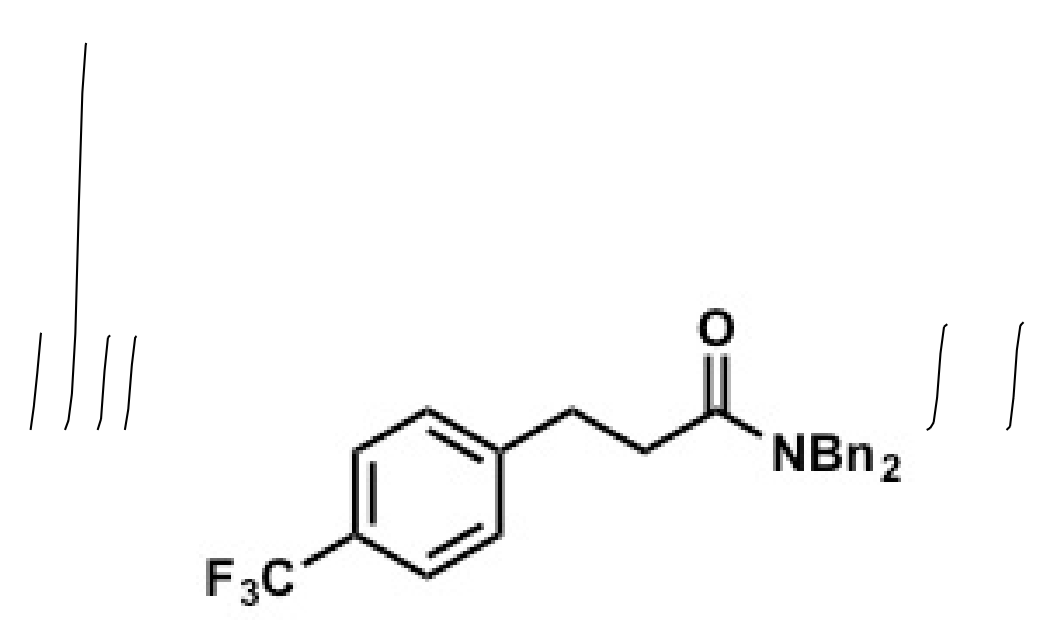

1h

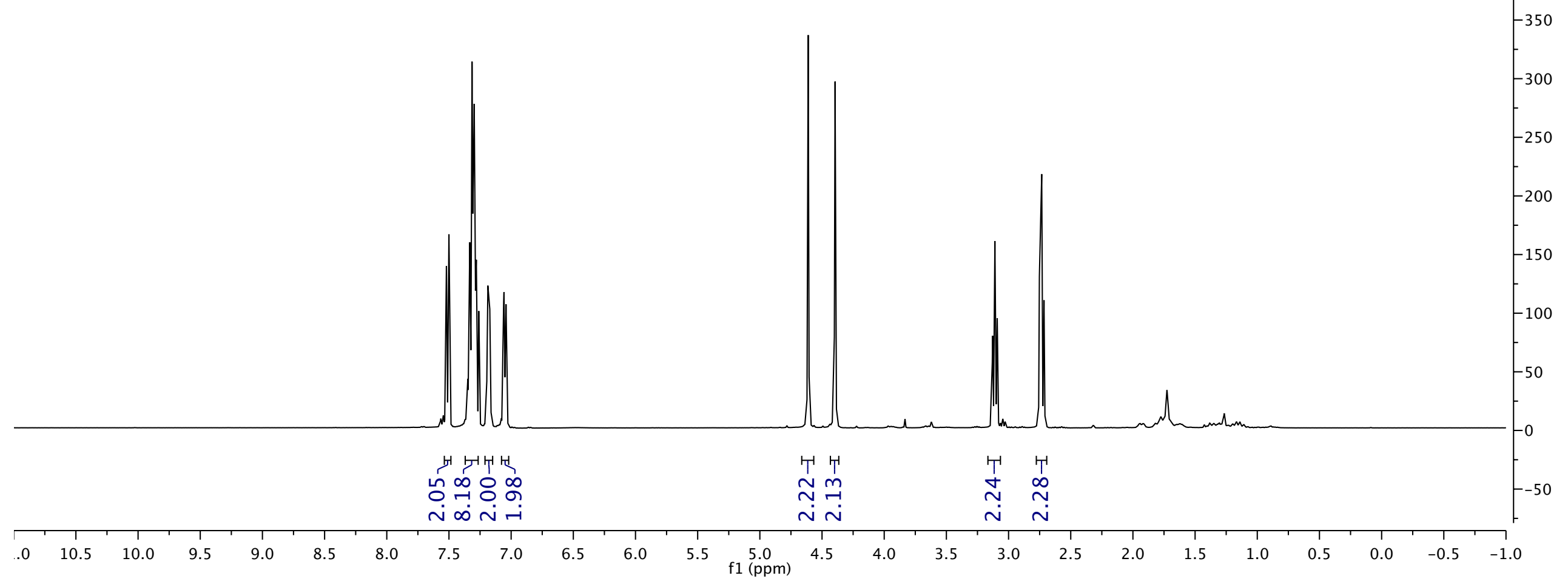



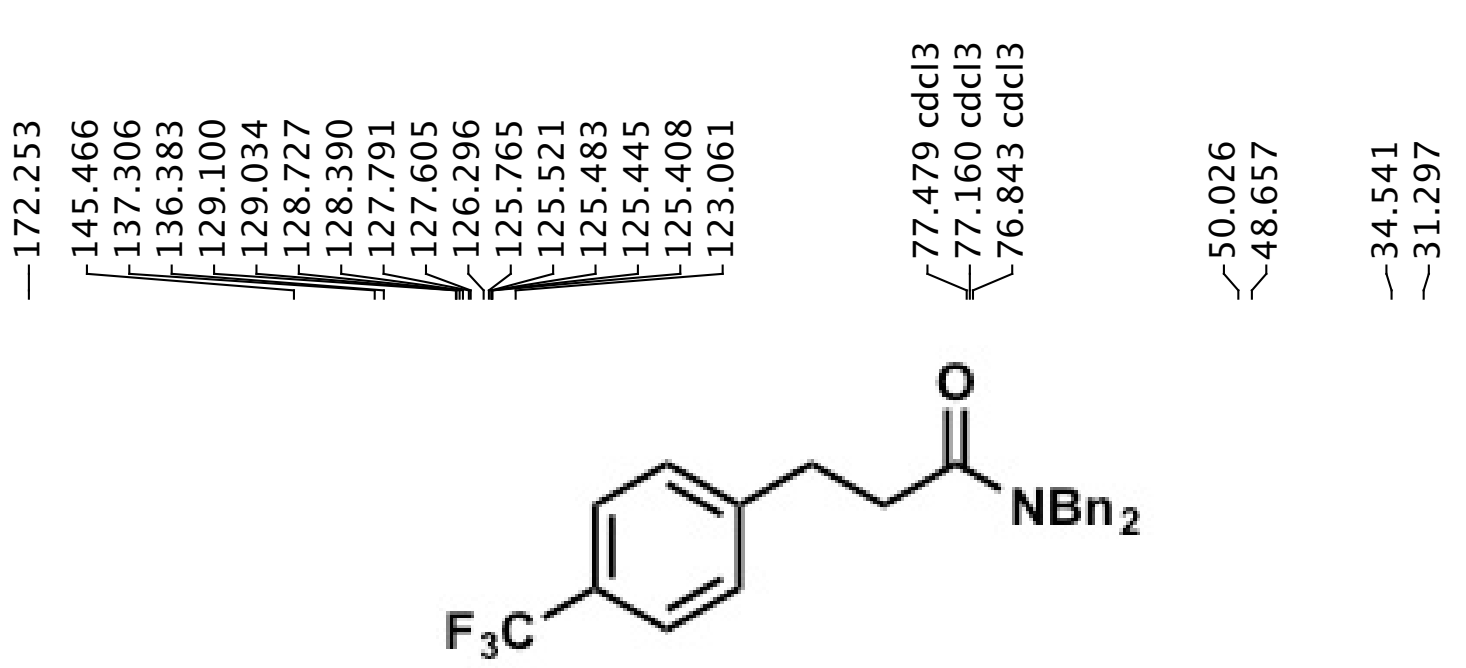

1h 

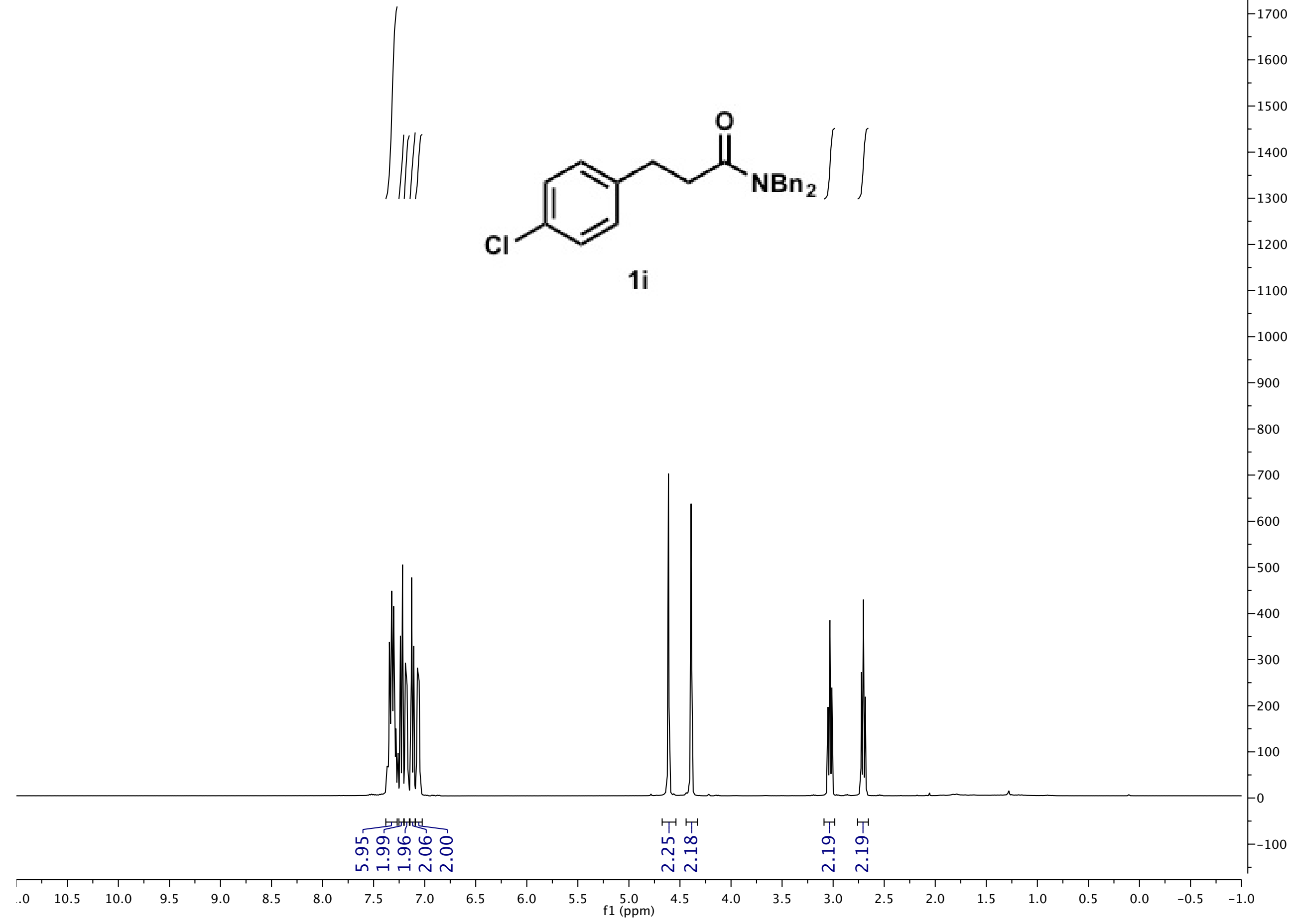


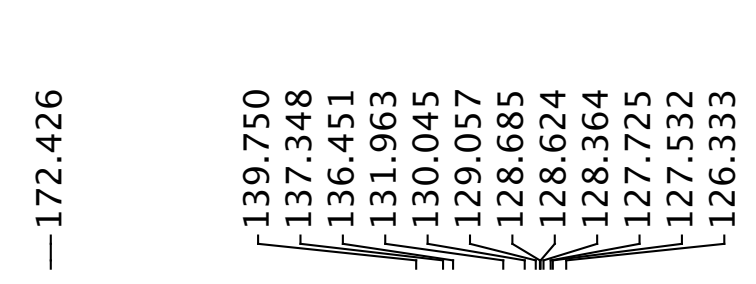<smiles>CCC(C)C(=O)CCc1ccc(Cl)cc1</smiles>

$1 \mathrm{i}$

\% 

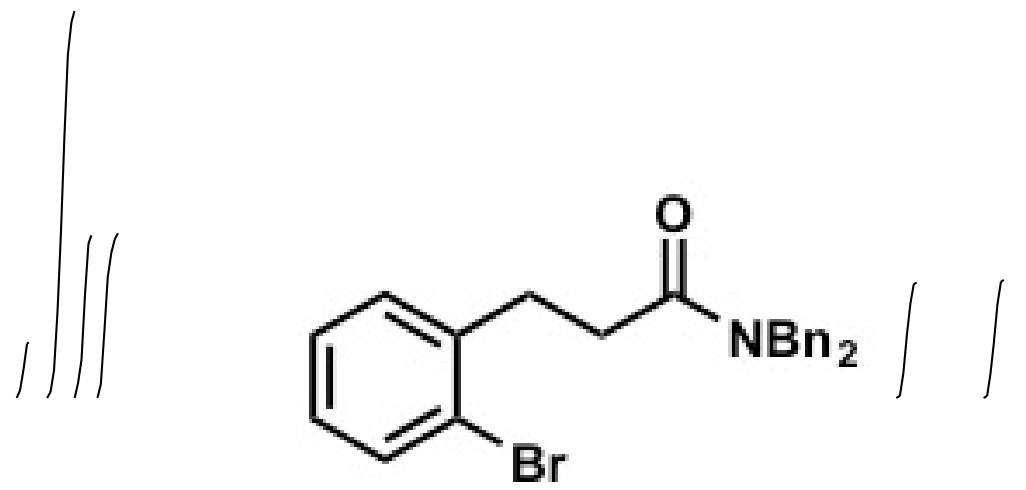

$1 \mathrm{j}$

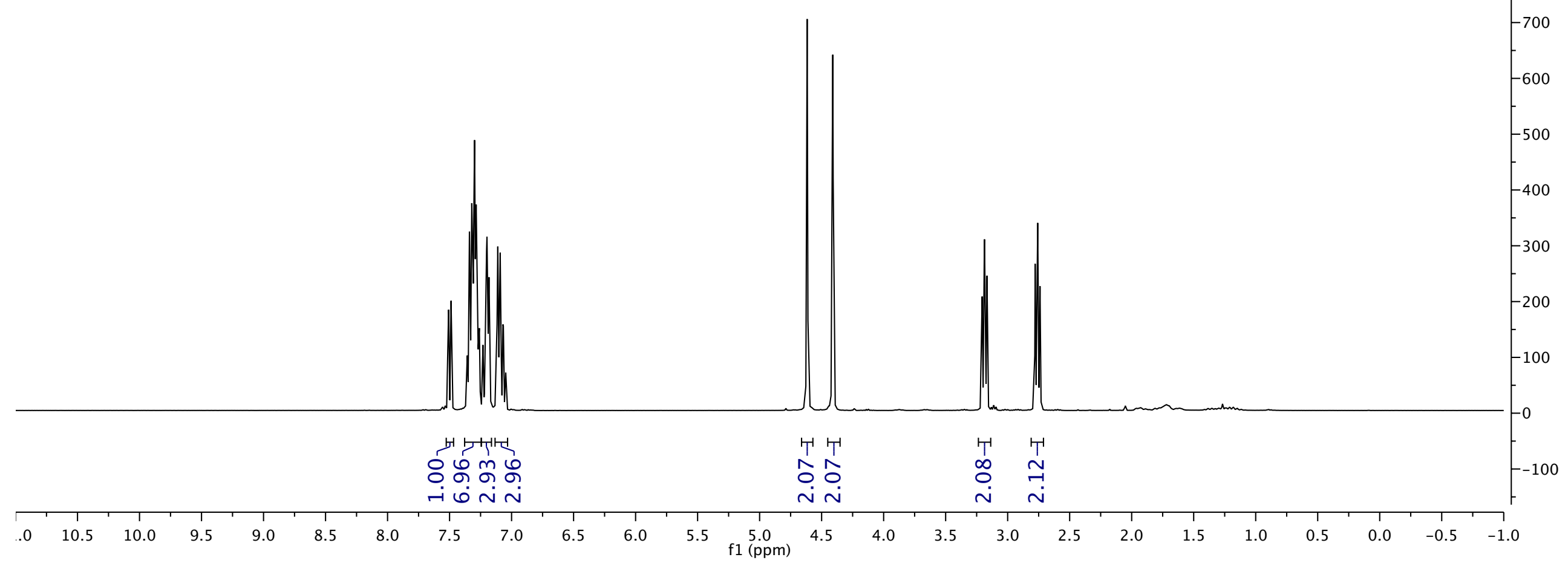




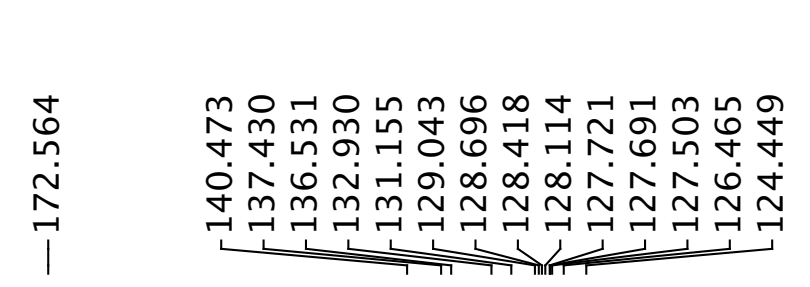

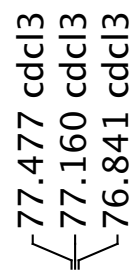
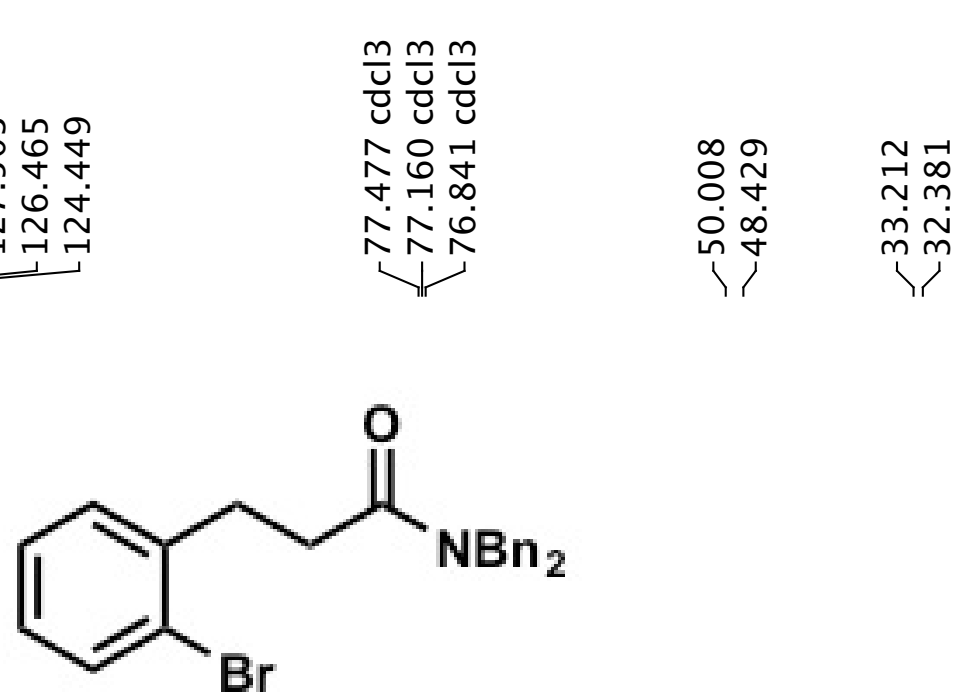

1j

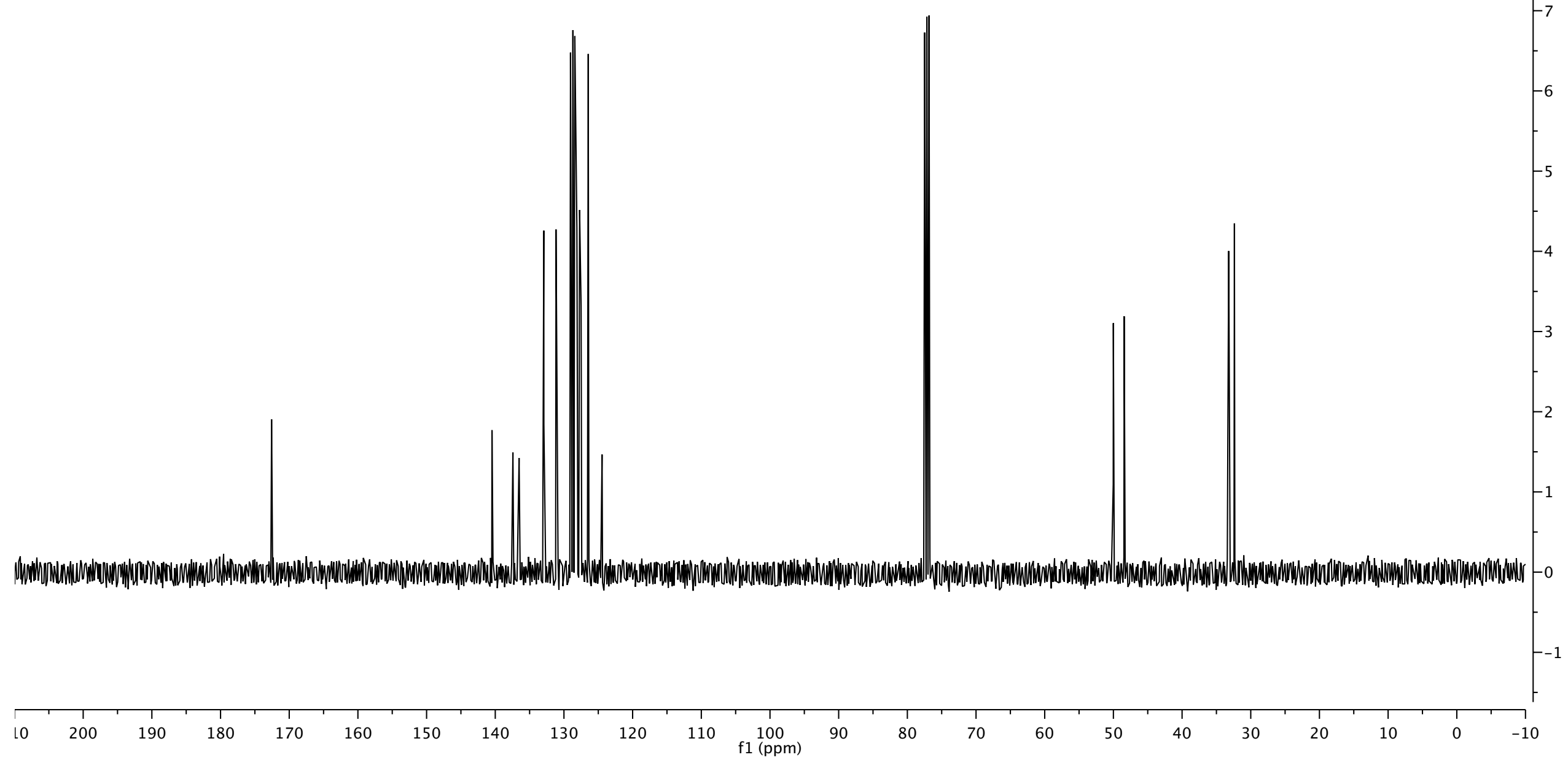



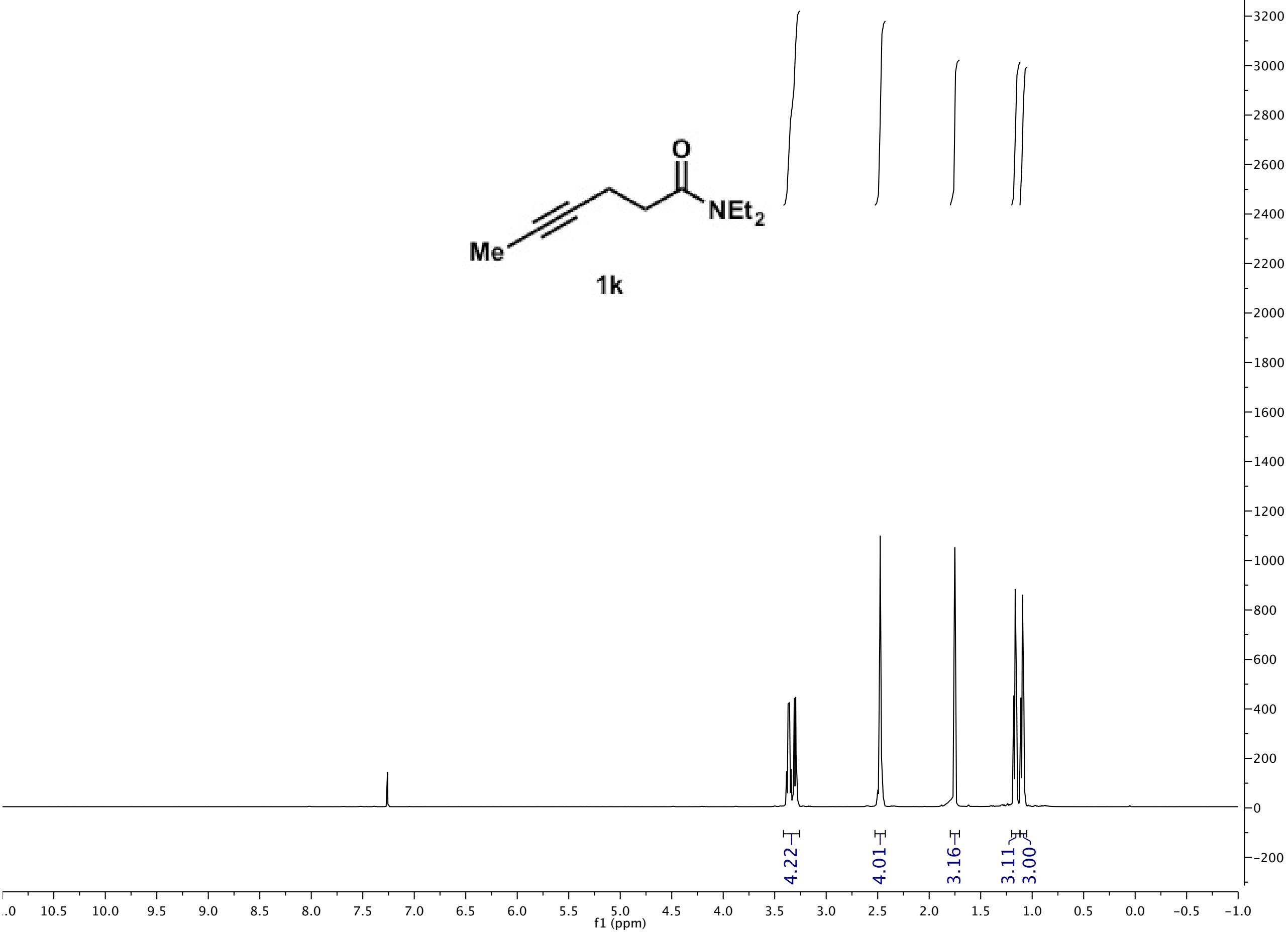


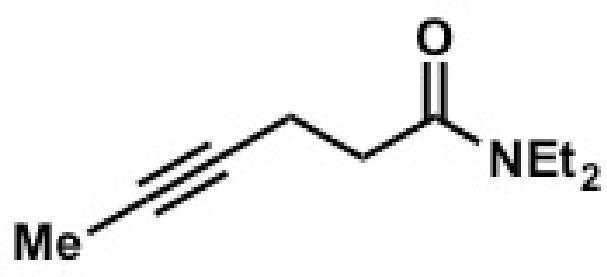

$1 \mathrm{k}$

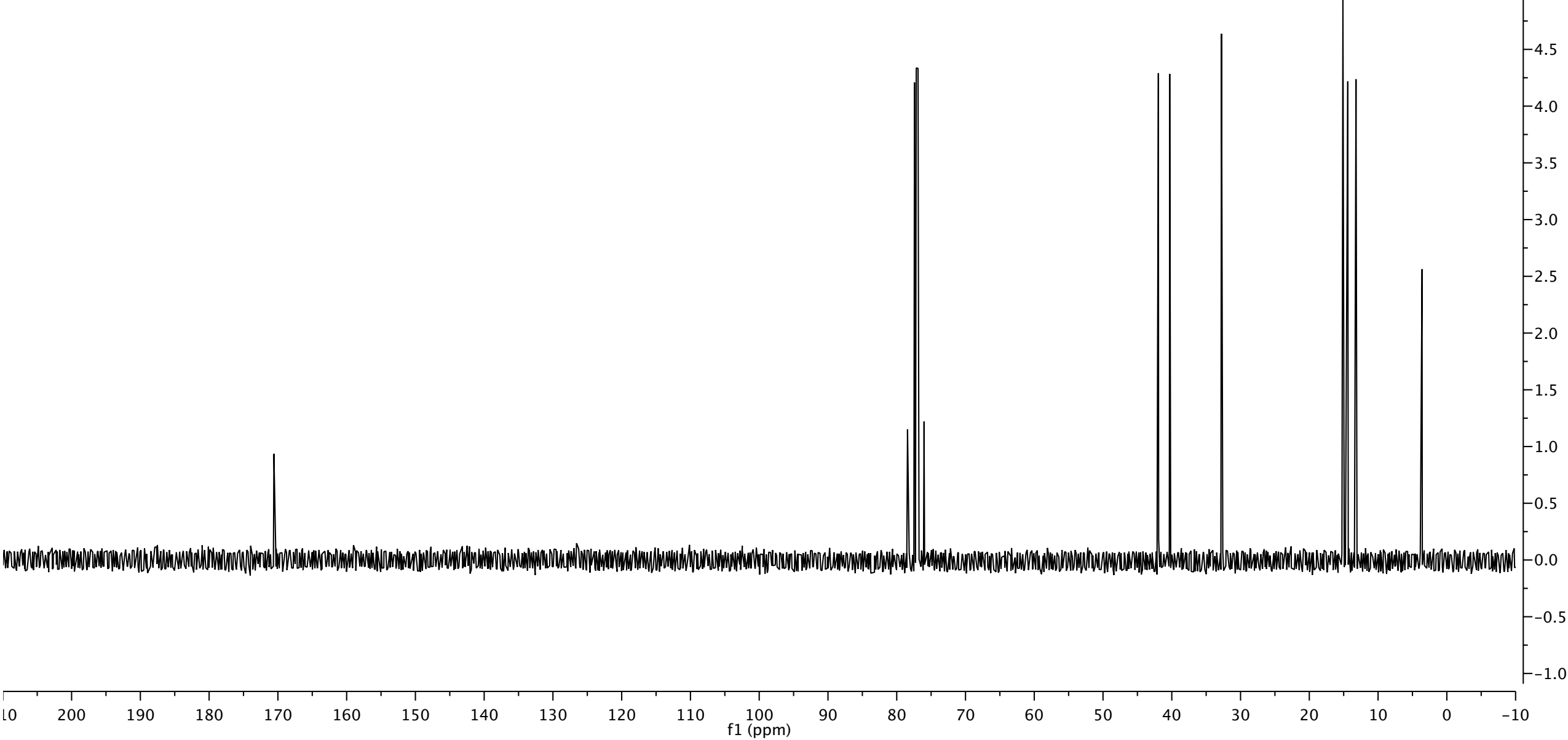




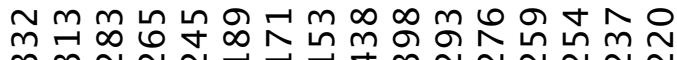
$m m N N N$ N ヘヘNヘNヘヘ

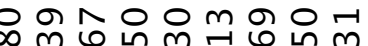
の

Ninn $\operatorname{nnn}$
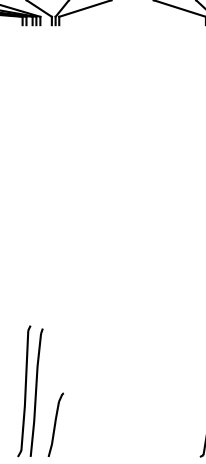<smiles>CN(C)C(=O)CC/C=C/c1ccccc1</smiles>

11

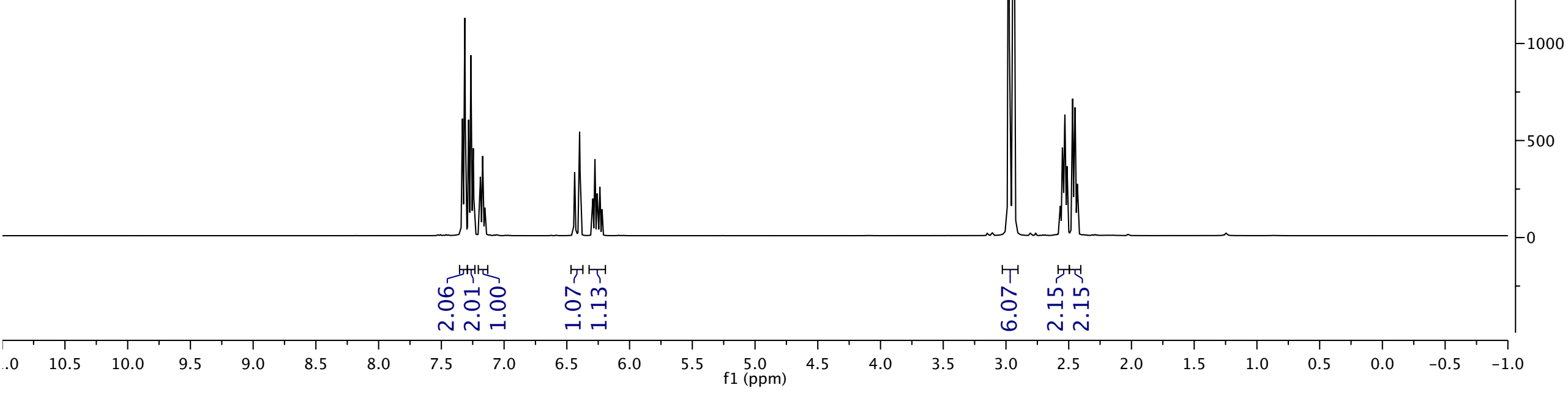



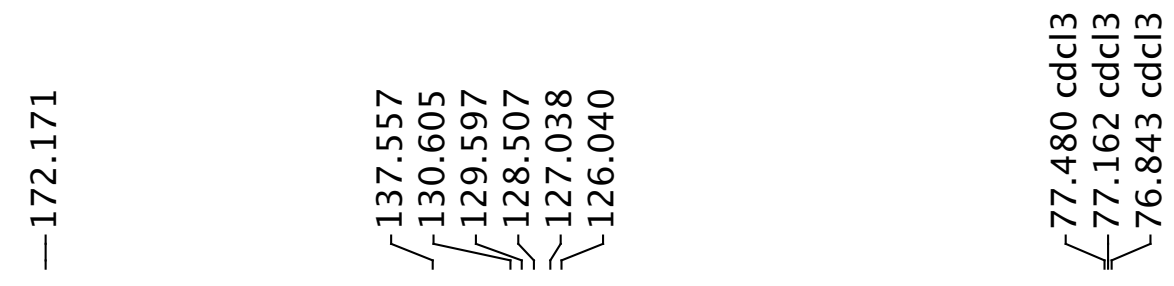

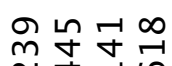

가

$\hat{n} \stackrel{n}{m} \stackrel{\infty}{\sim}$

रा?

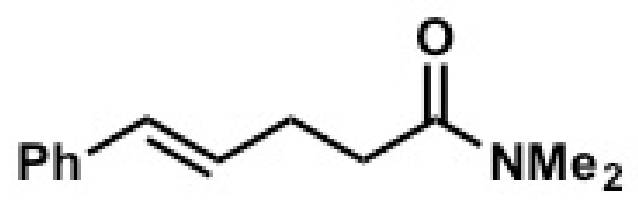

11

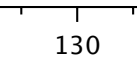




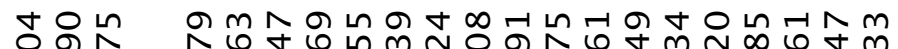
+

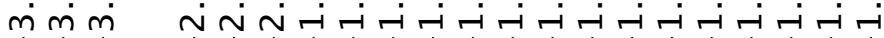
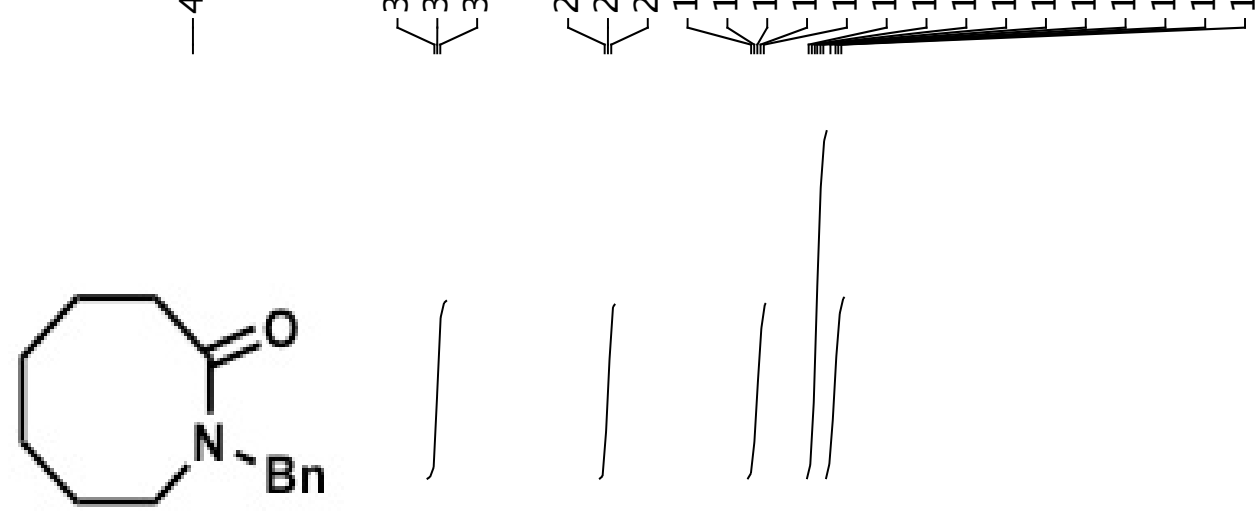

$1 \mathrm{p}$

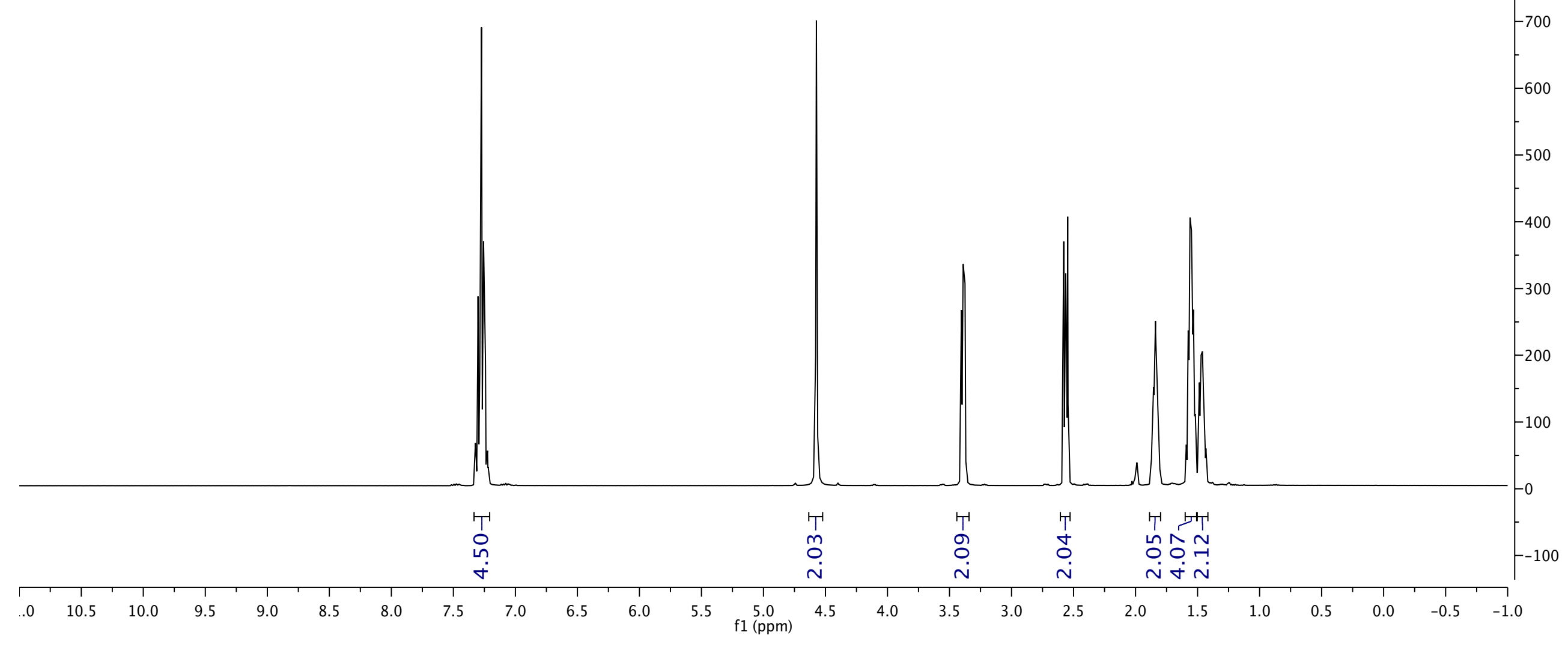



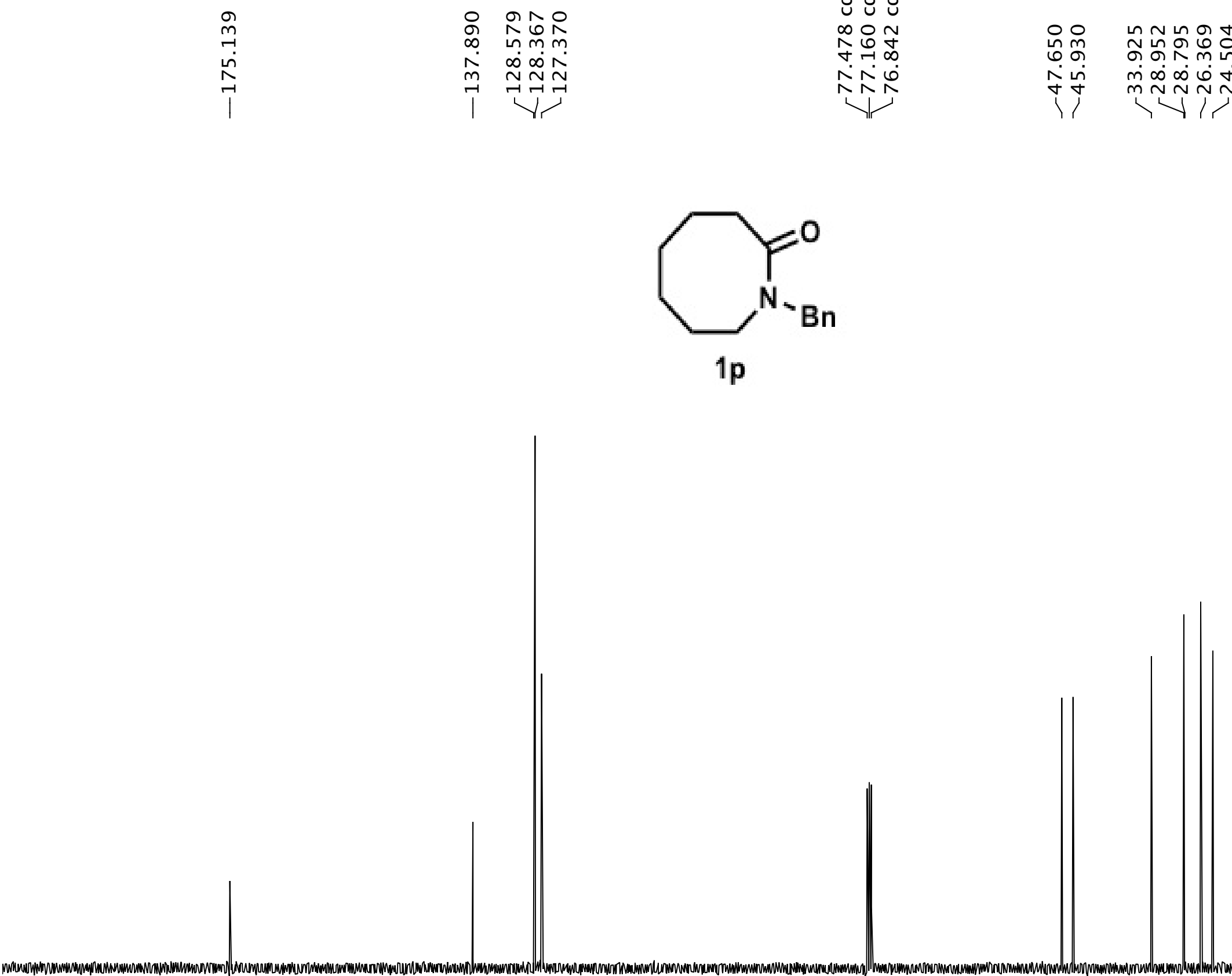


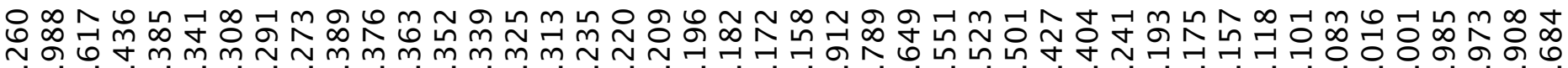
ヘ m

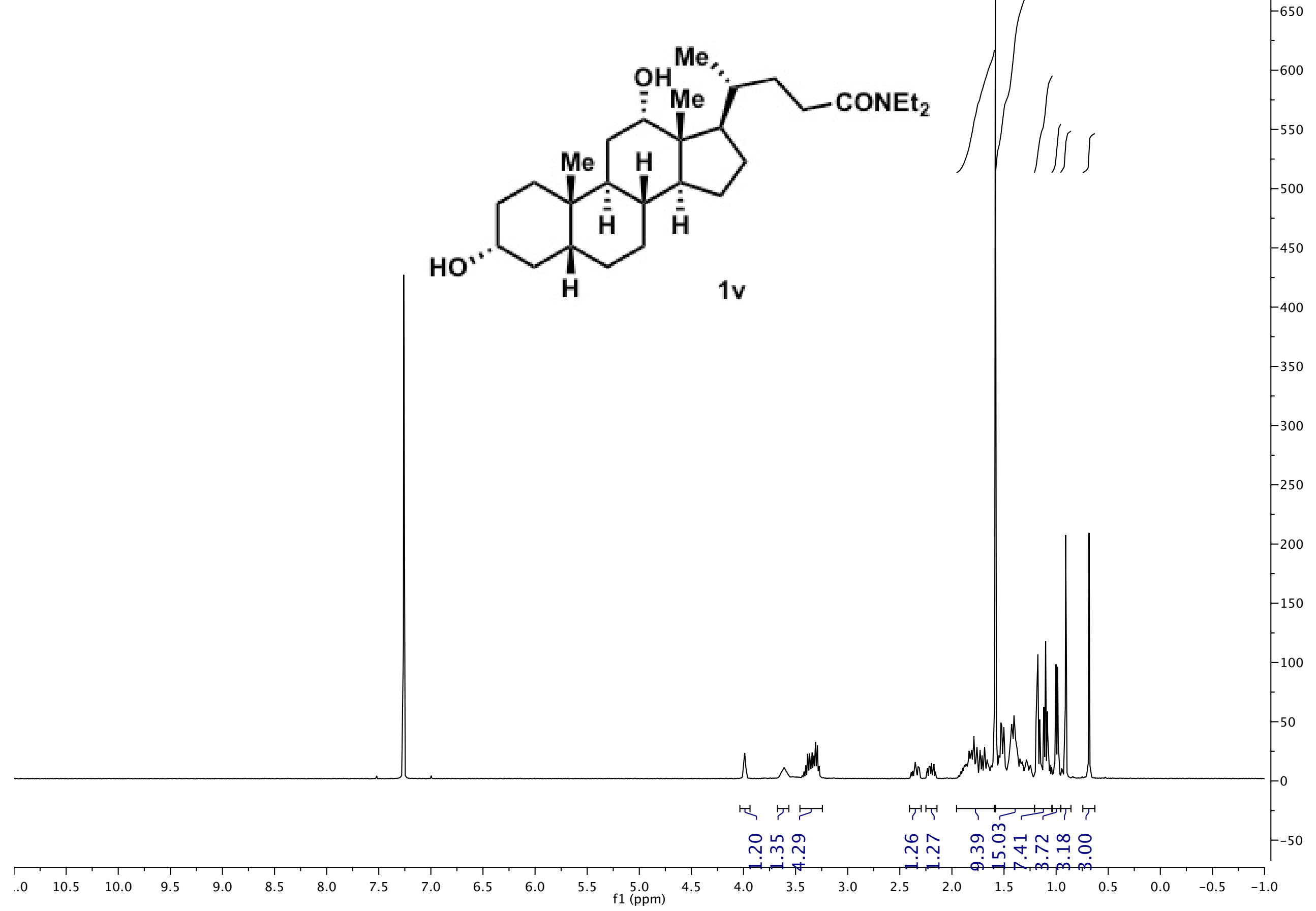



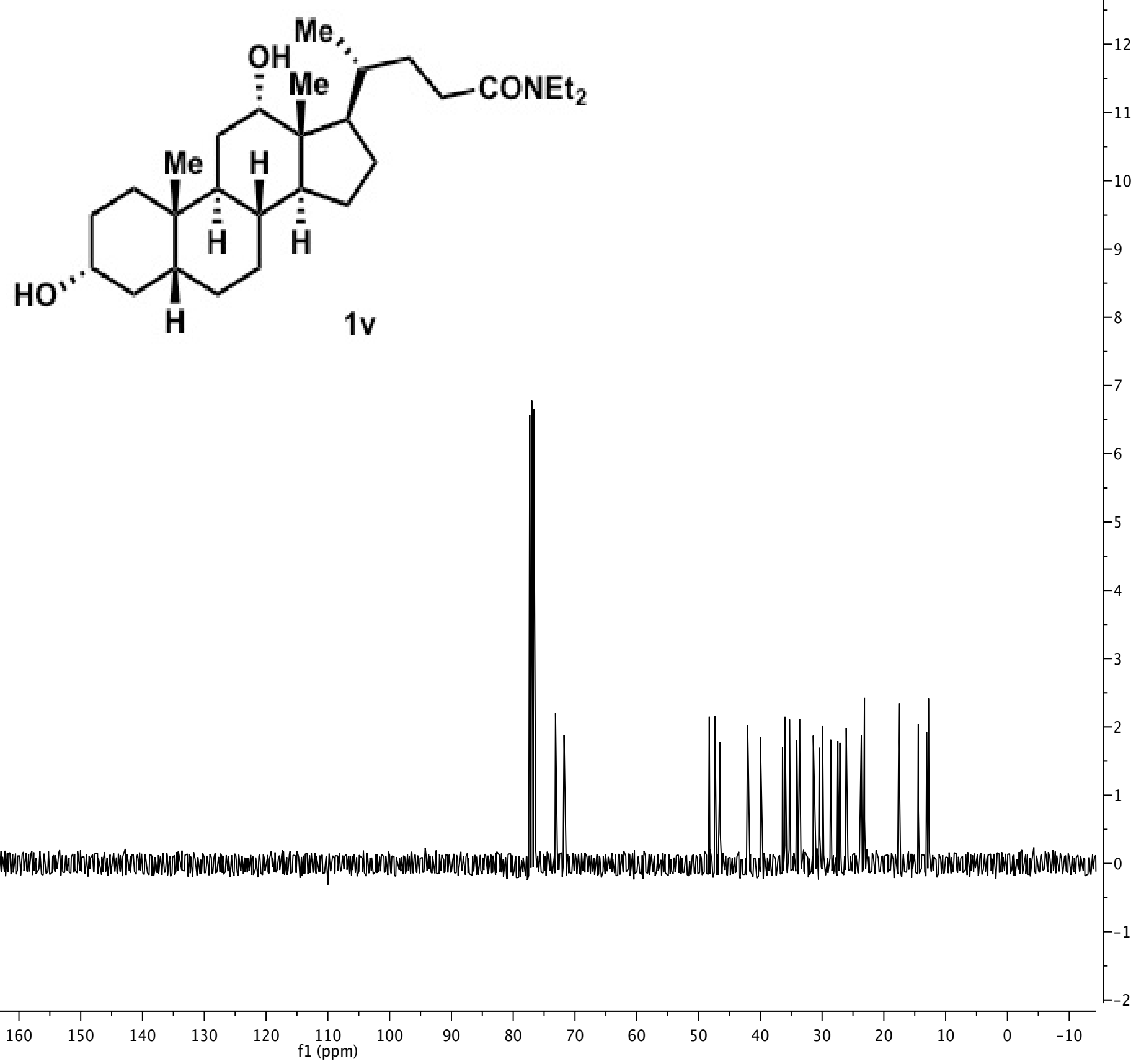


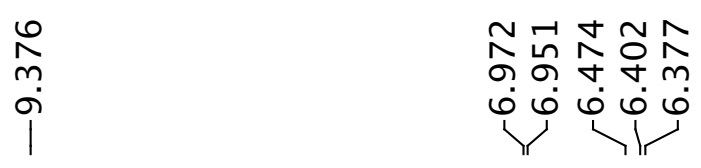

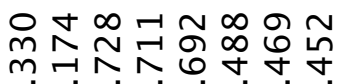

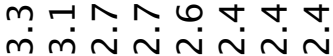

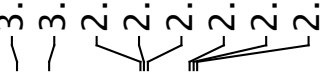

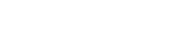

$\int$

11
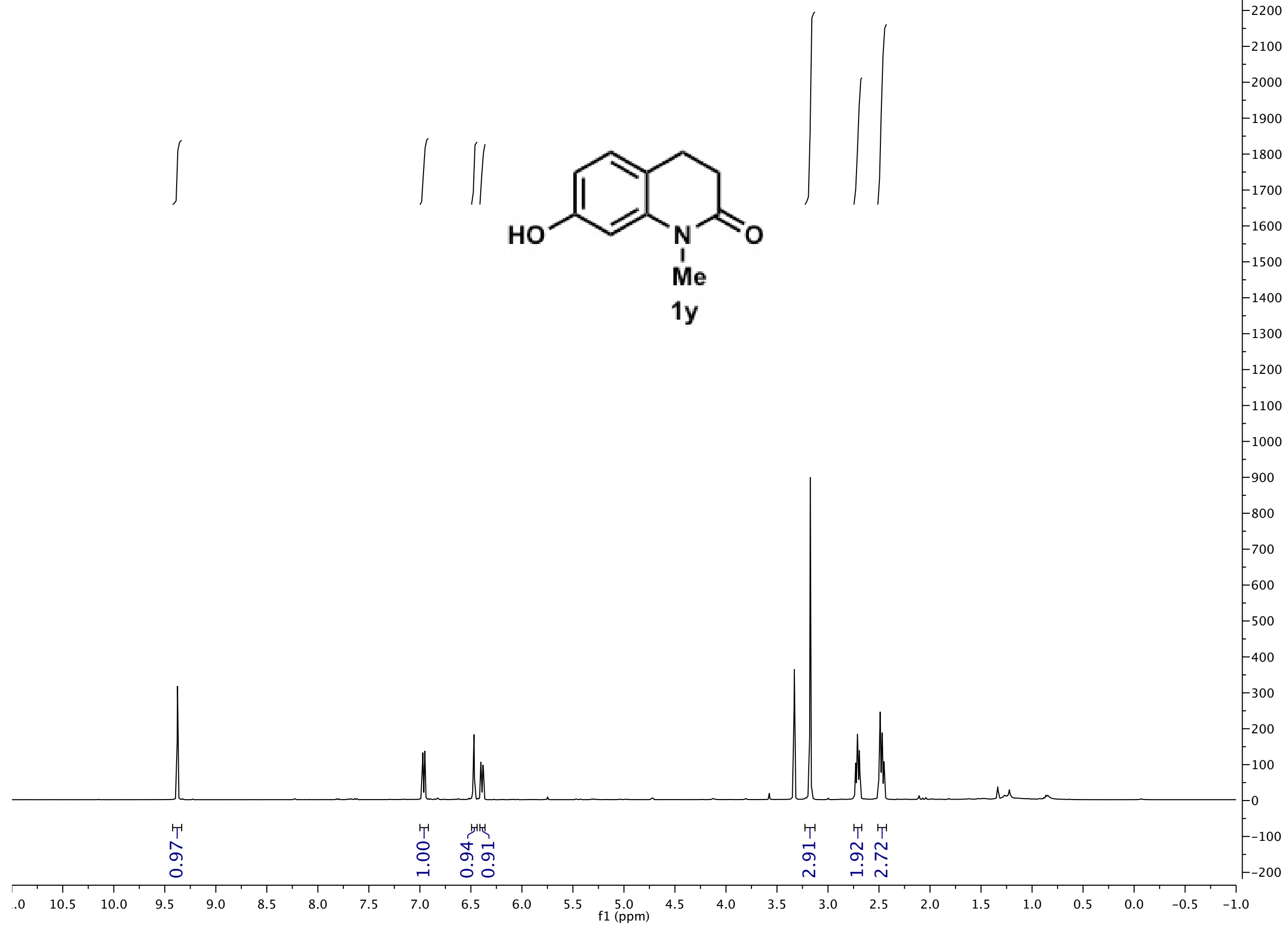


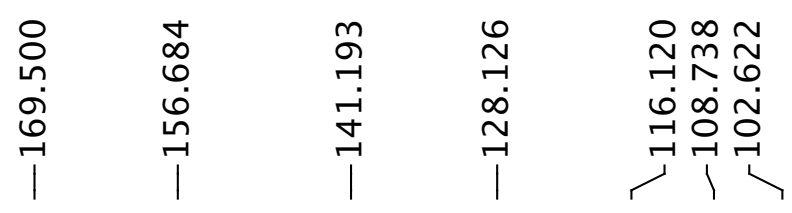

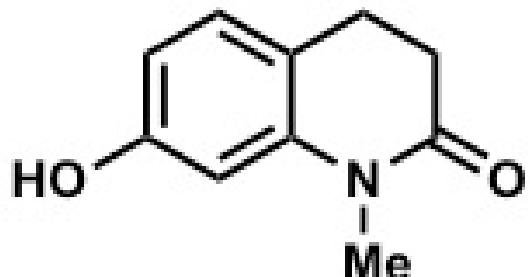




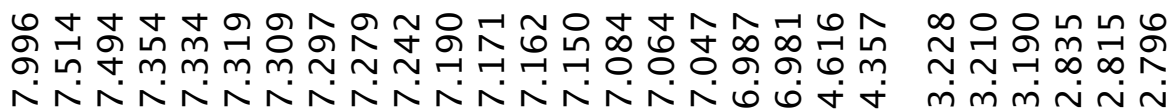

$\hat{1})$
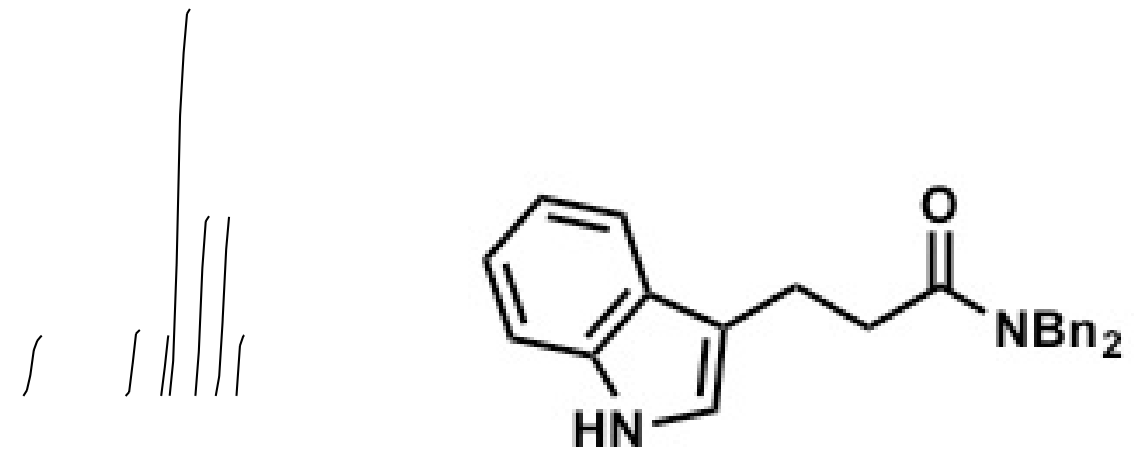

$1 z$

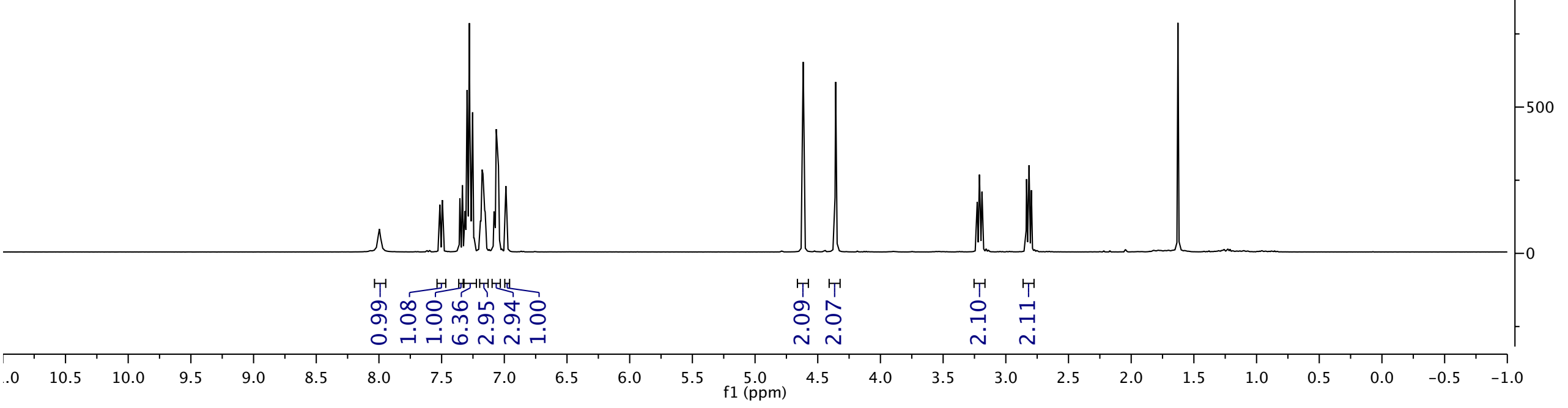


<smiles>CCC(C)NC(=O)CCc1c[nH]c2ccccc12</smiles>

$1 z$

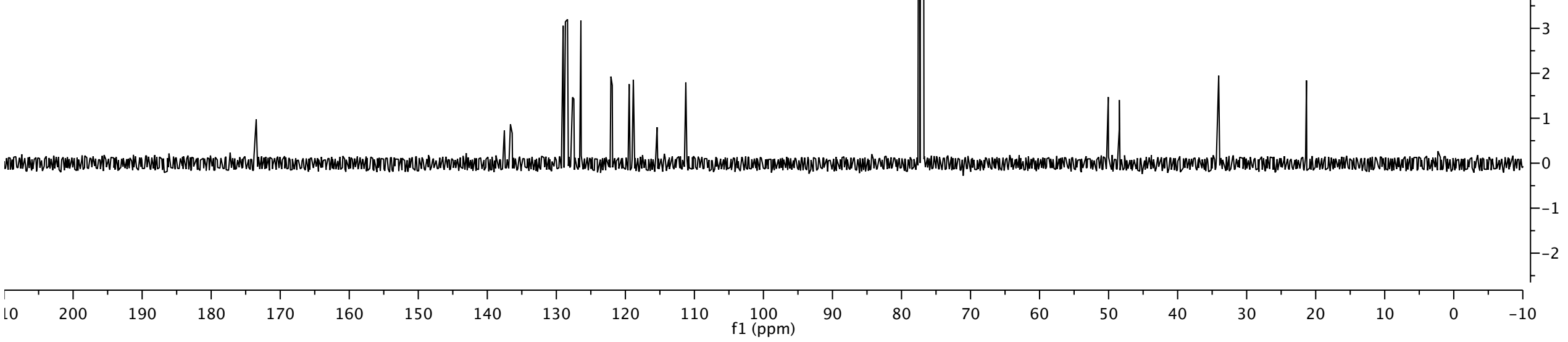




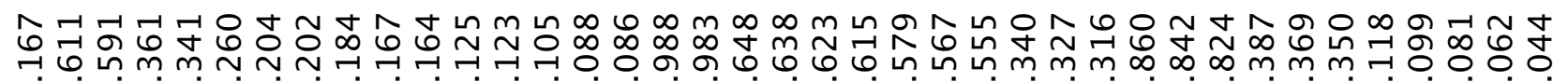

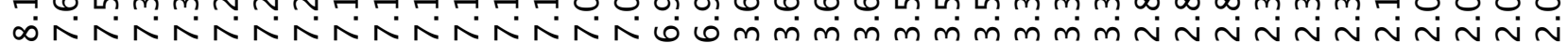

型

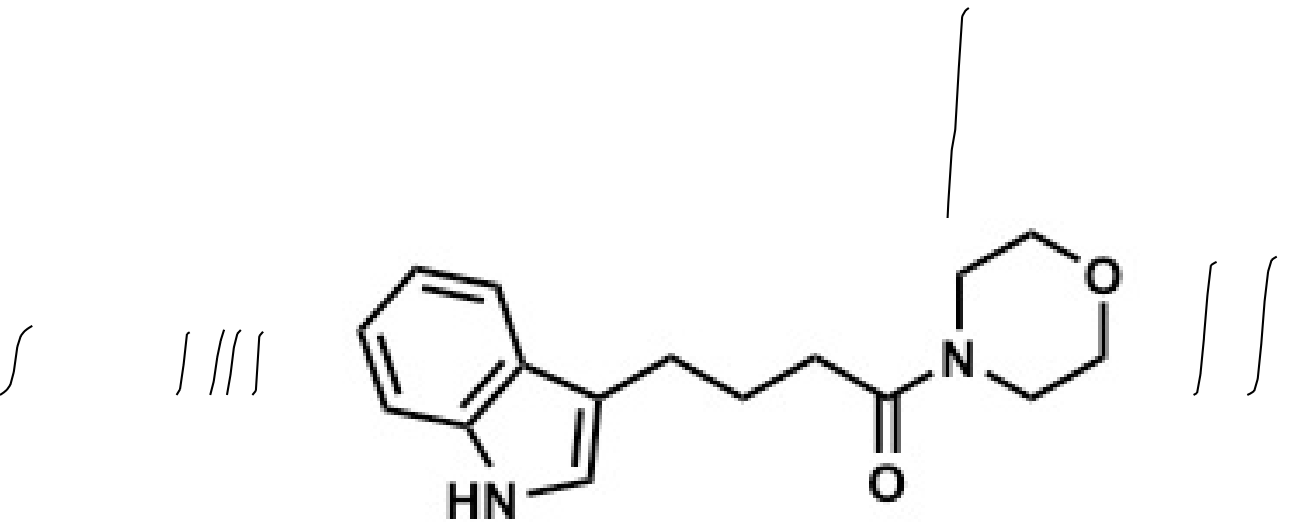

1 aa

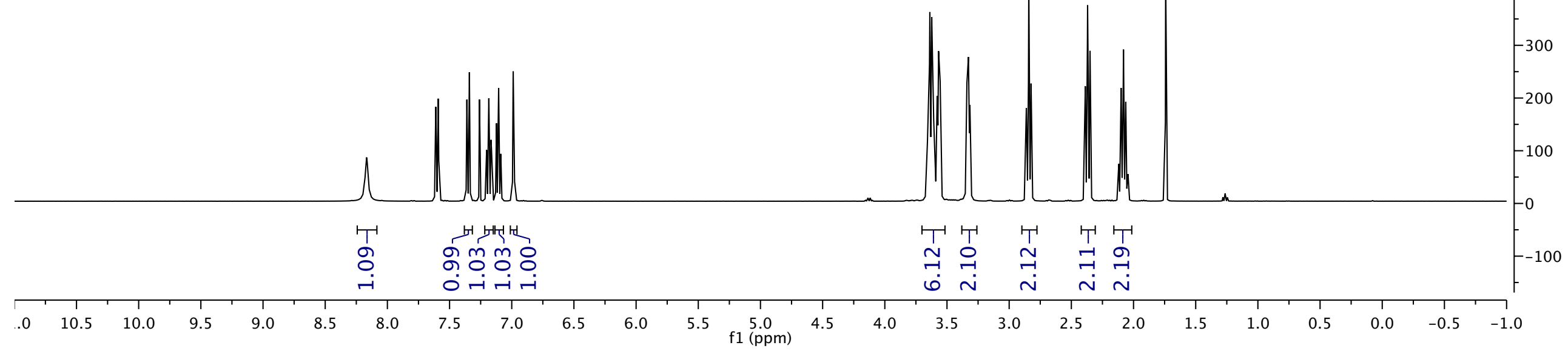




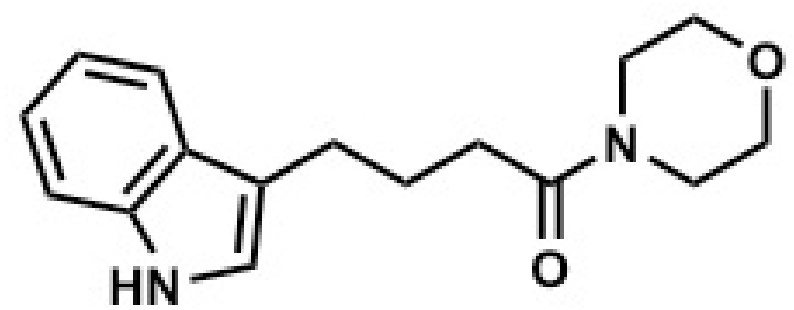

1 aa 

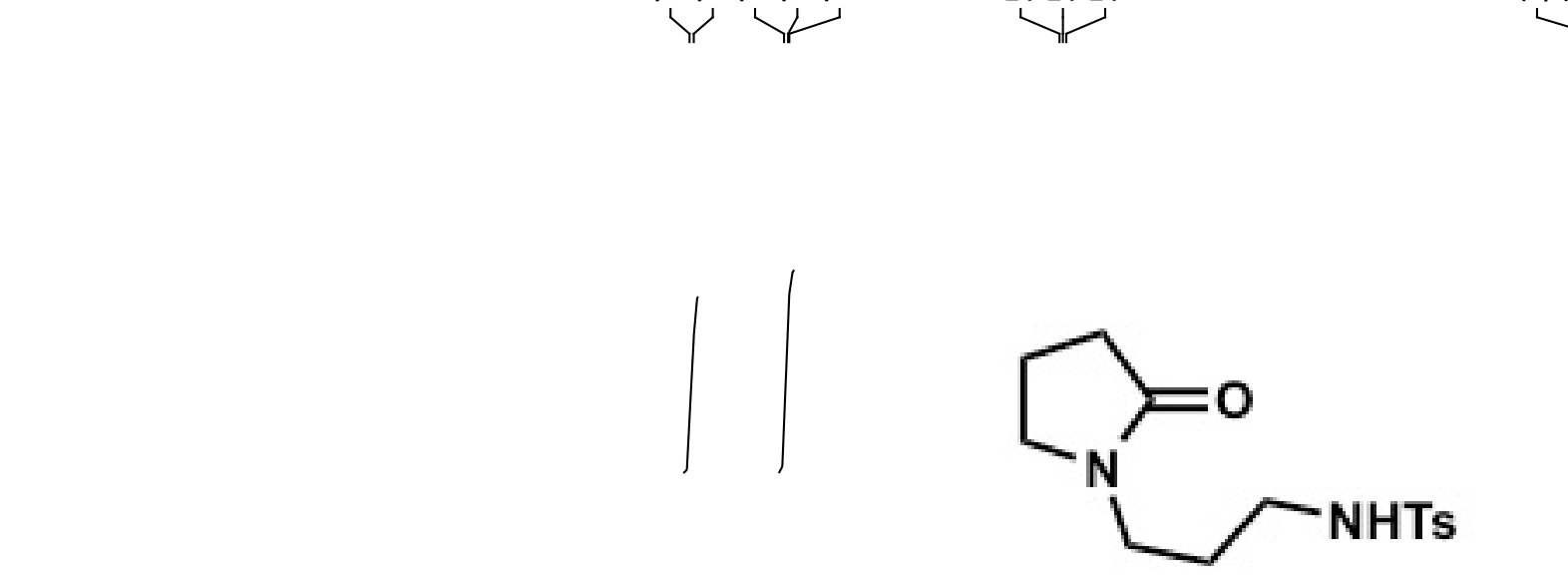

$1 a b$

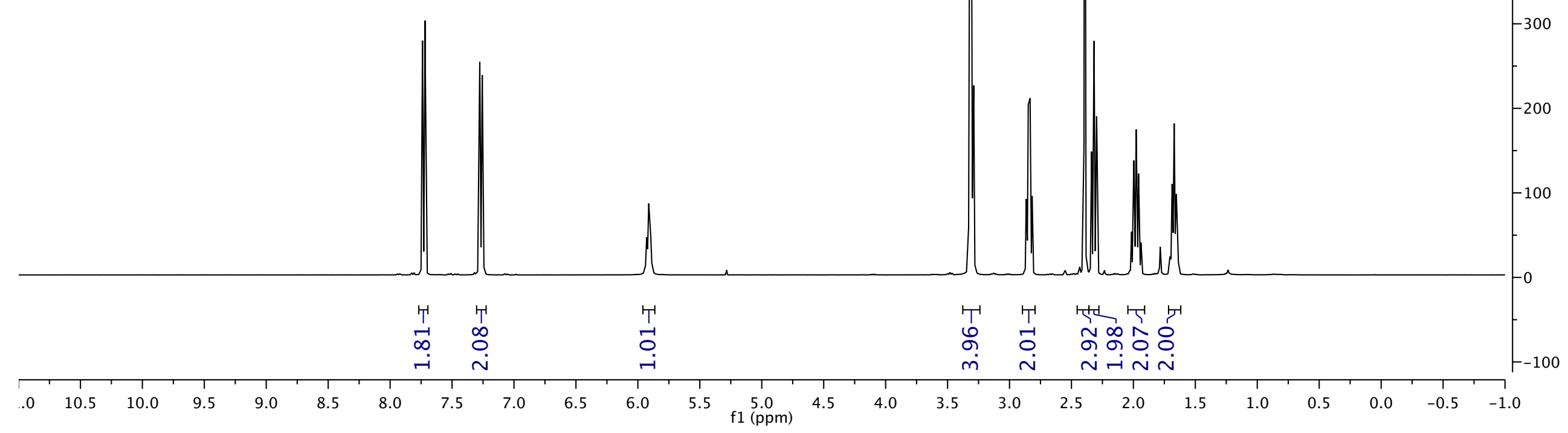




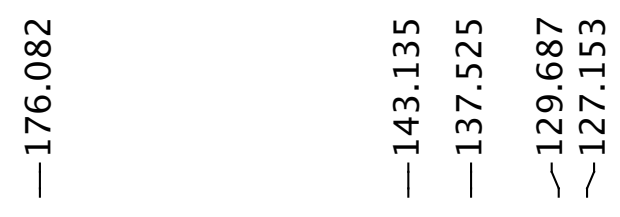

$\frac{m}{\bar{v}} \frac{m}{\bar{v}} \frac{m}{i}$

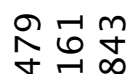

수

包

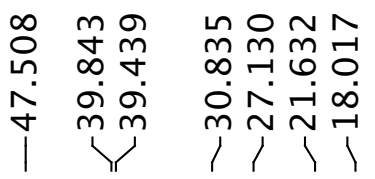

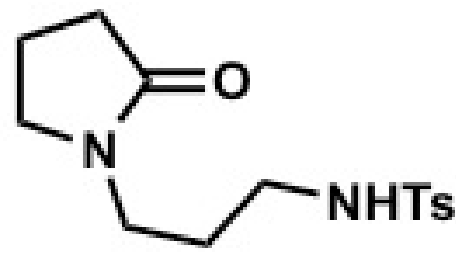

$1 \mathrm{ab}$ 


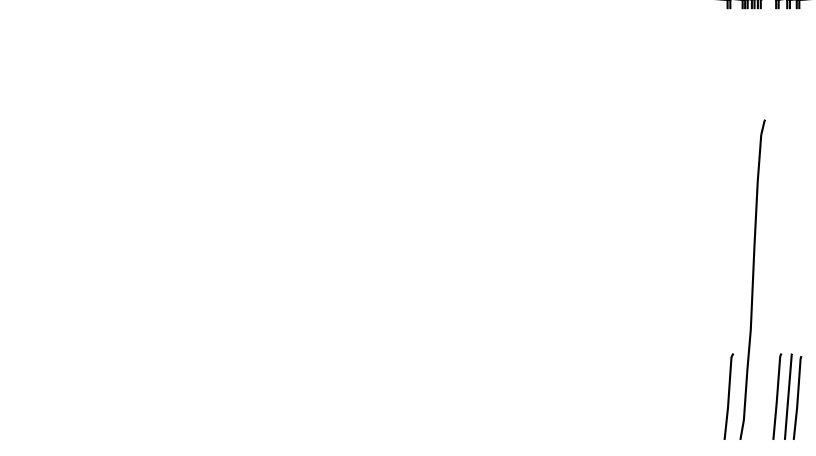

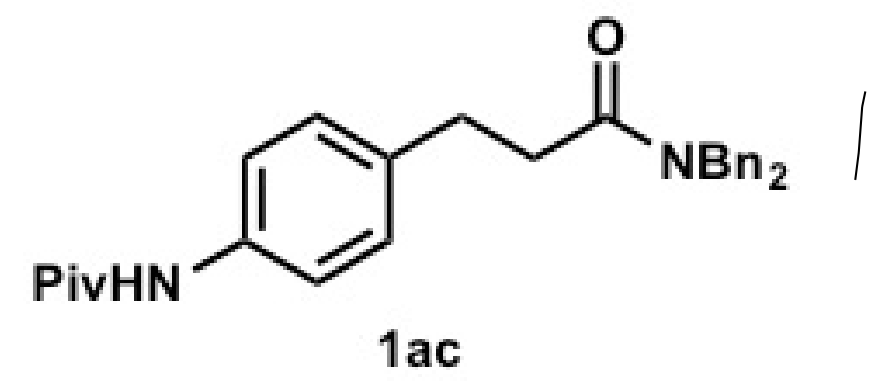

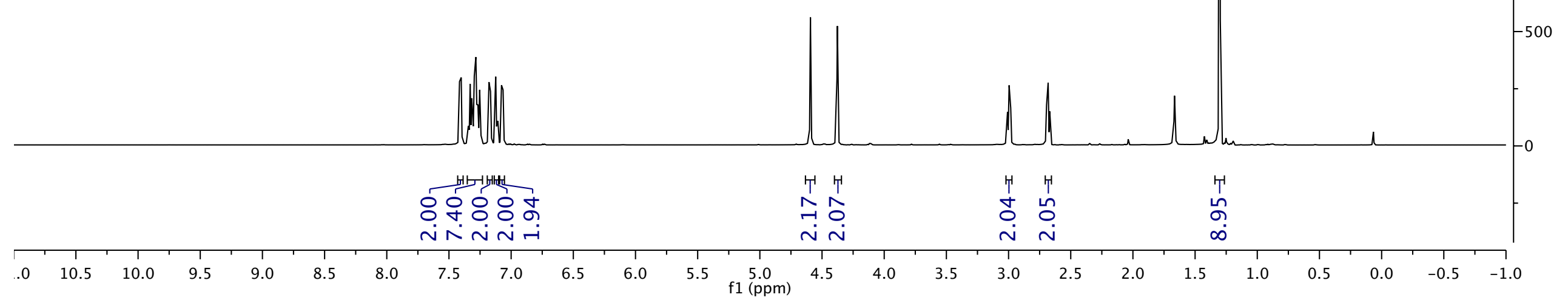



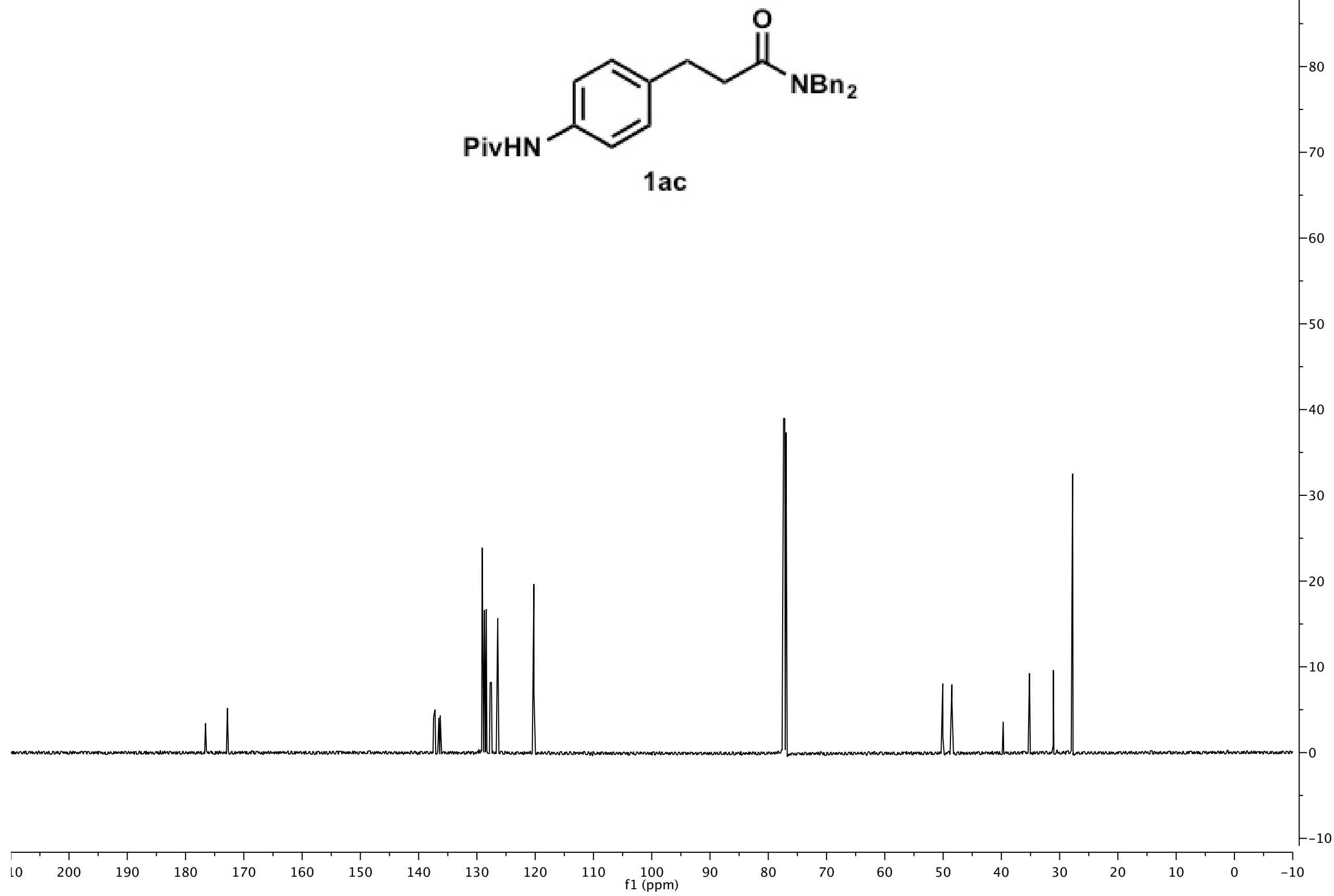
1 ad

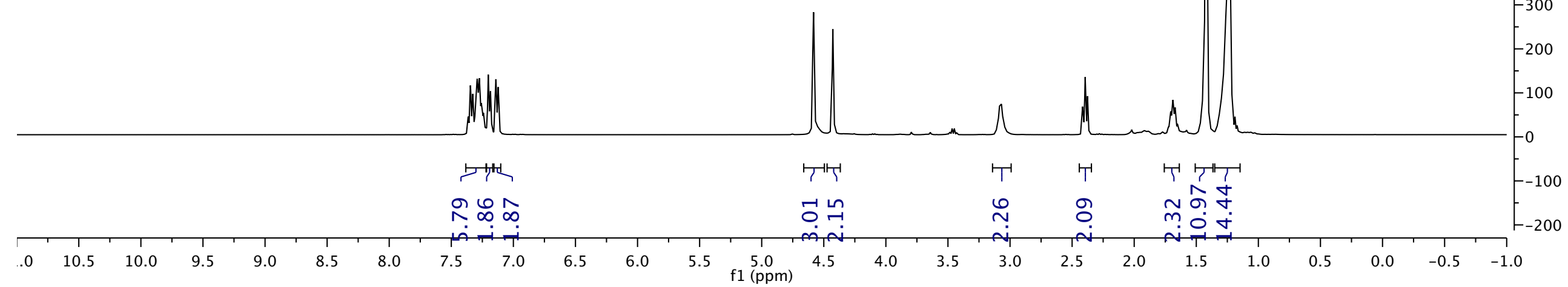


<smiles>CCCCC(=O)NCCCCC(=O)O</smiles>

1 ad

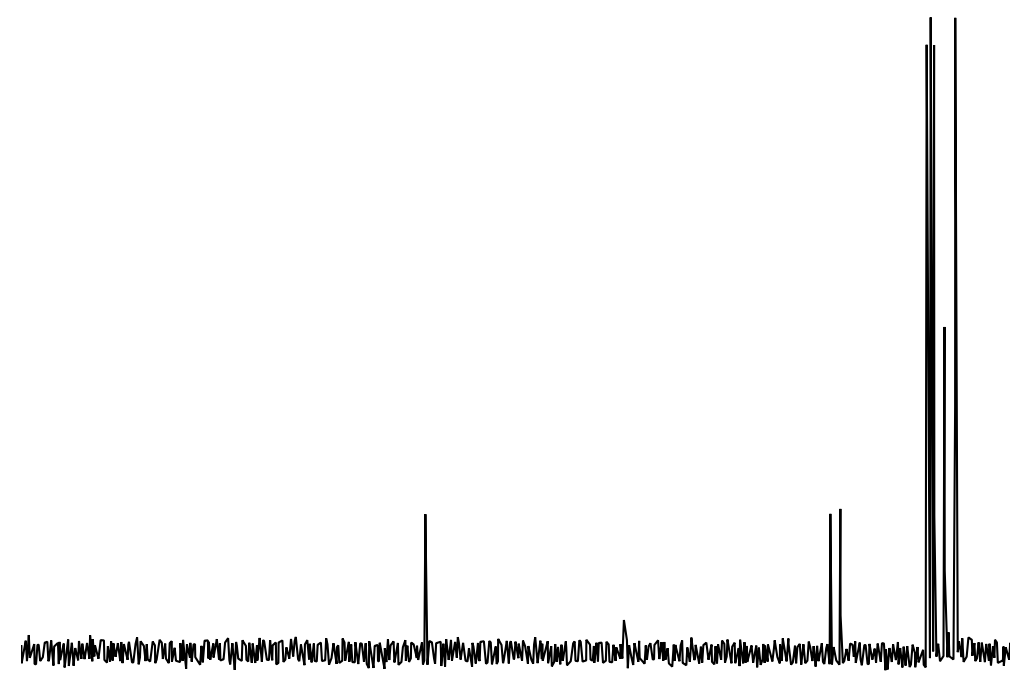

$\mathrm{NBn}_{2}$

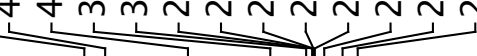



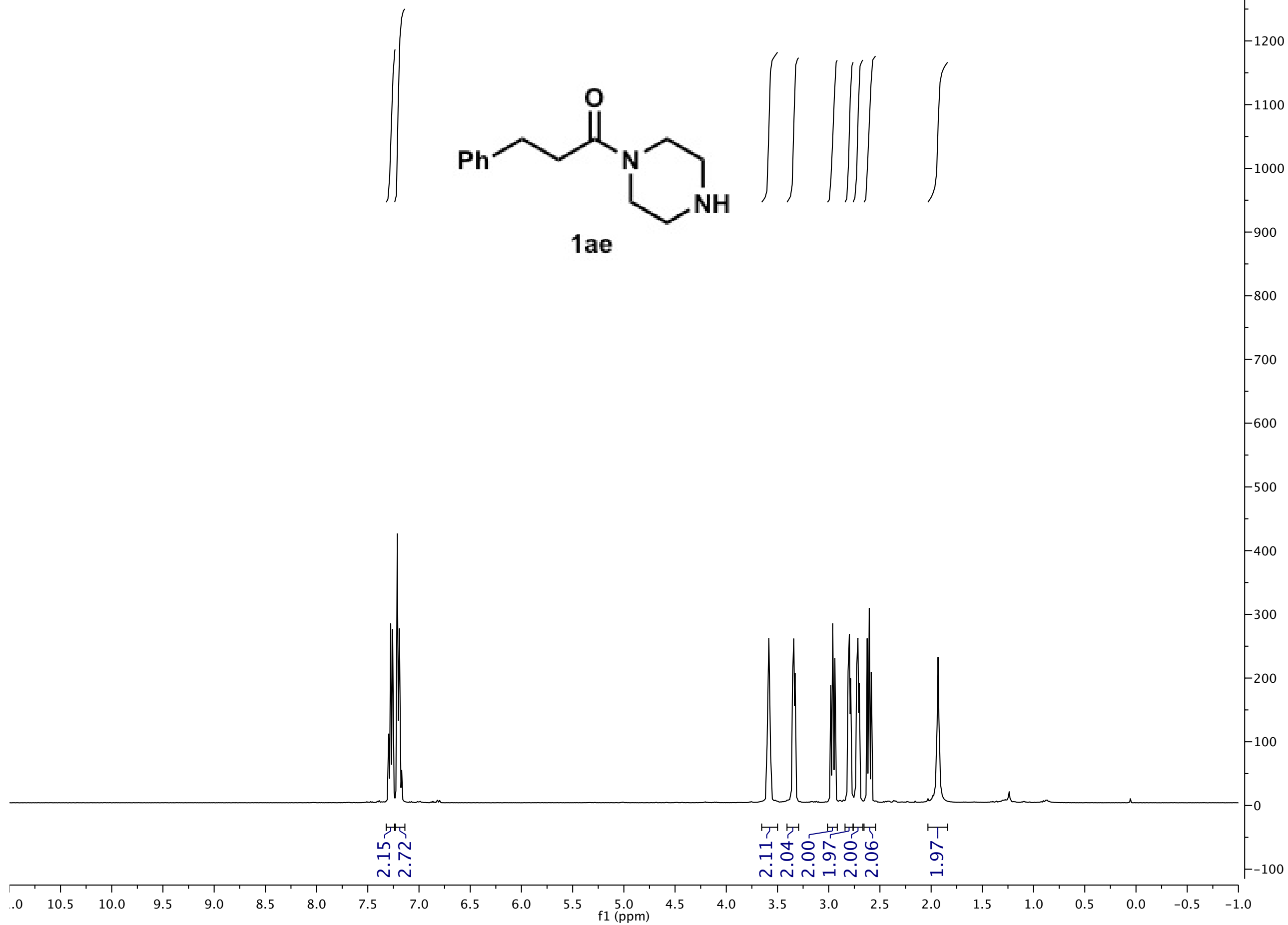


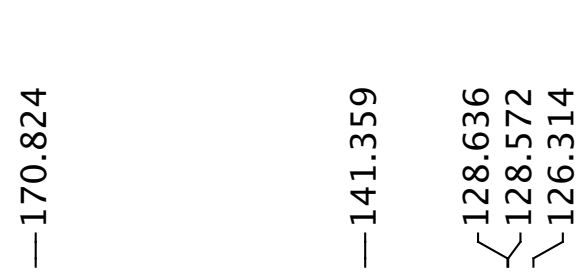

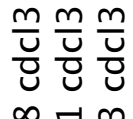

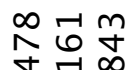

ヘิ์

रN

논

ம் ம⿻

?<smiles>O=C(CCc1ccccc1)N1CCNCC1</smiles>

1 ae

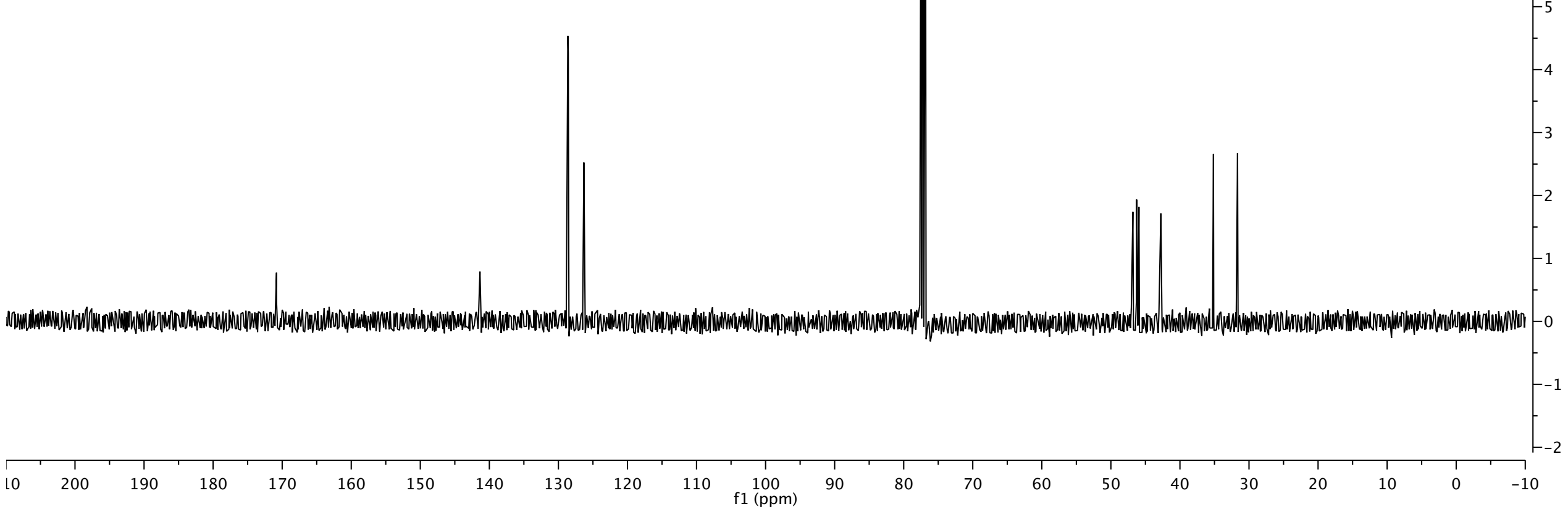




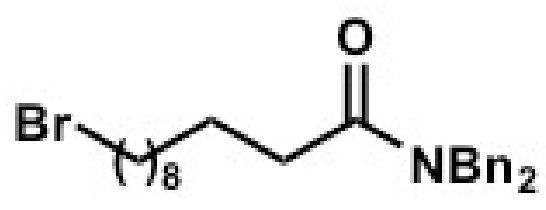

SI-1
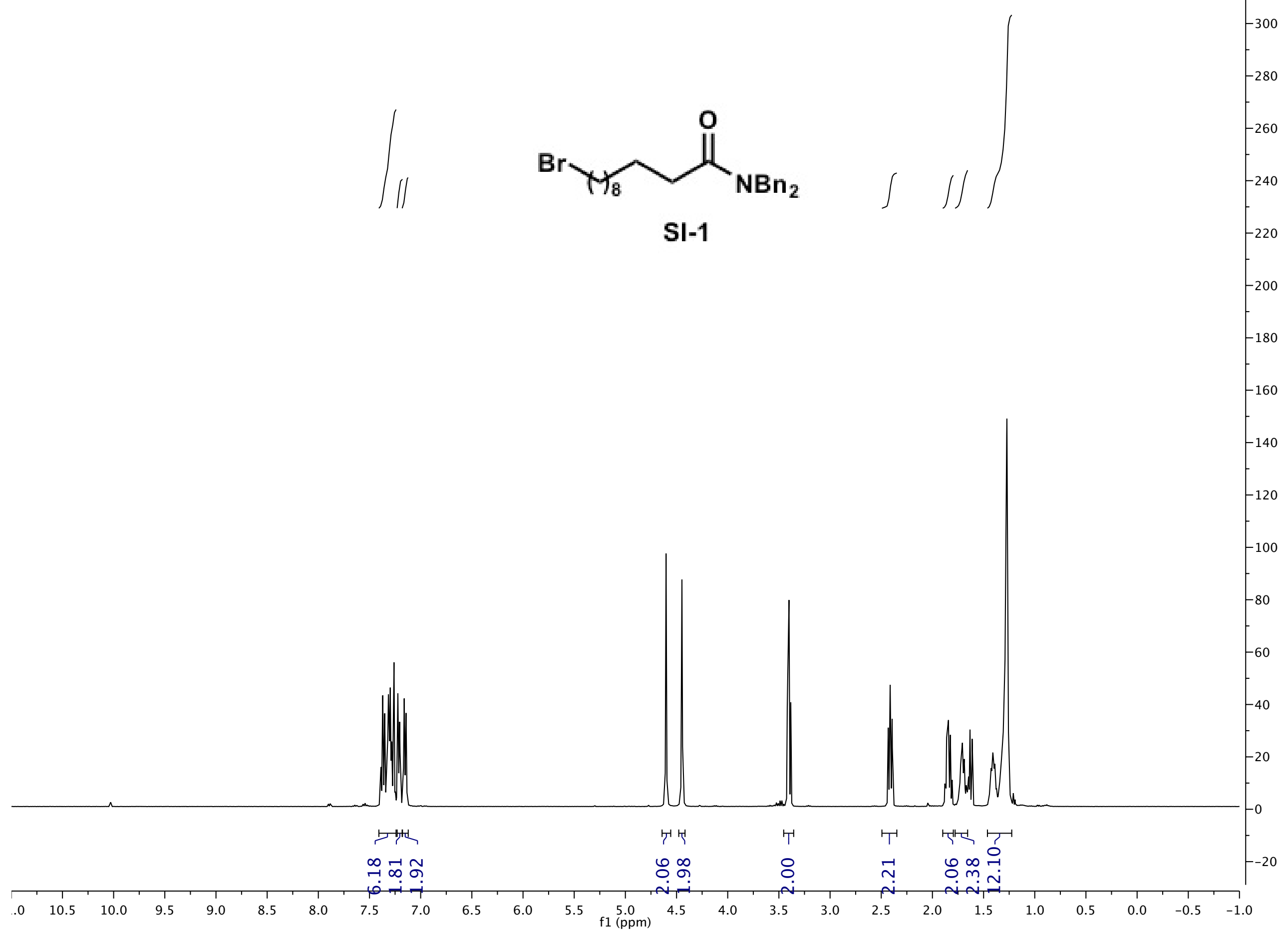


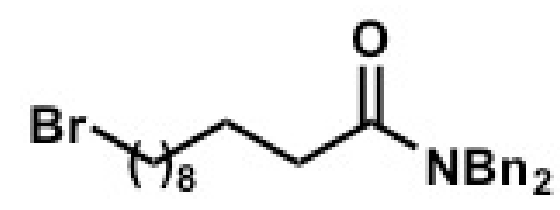

SI-1
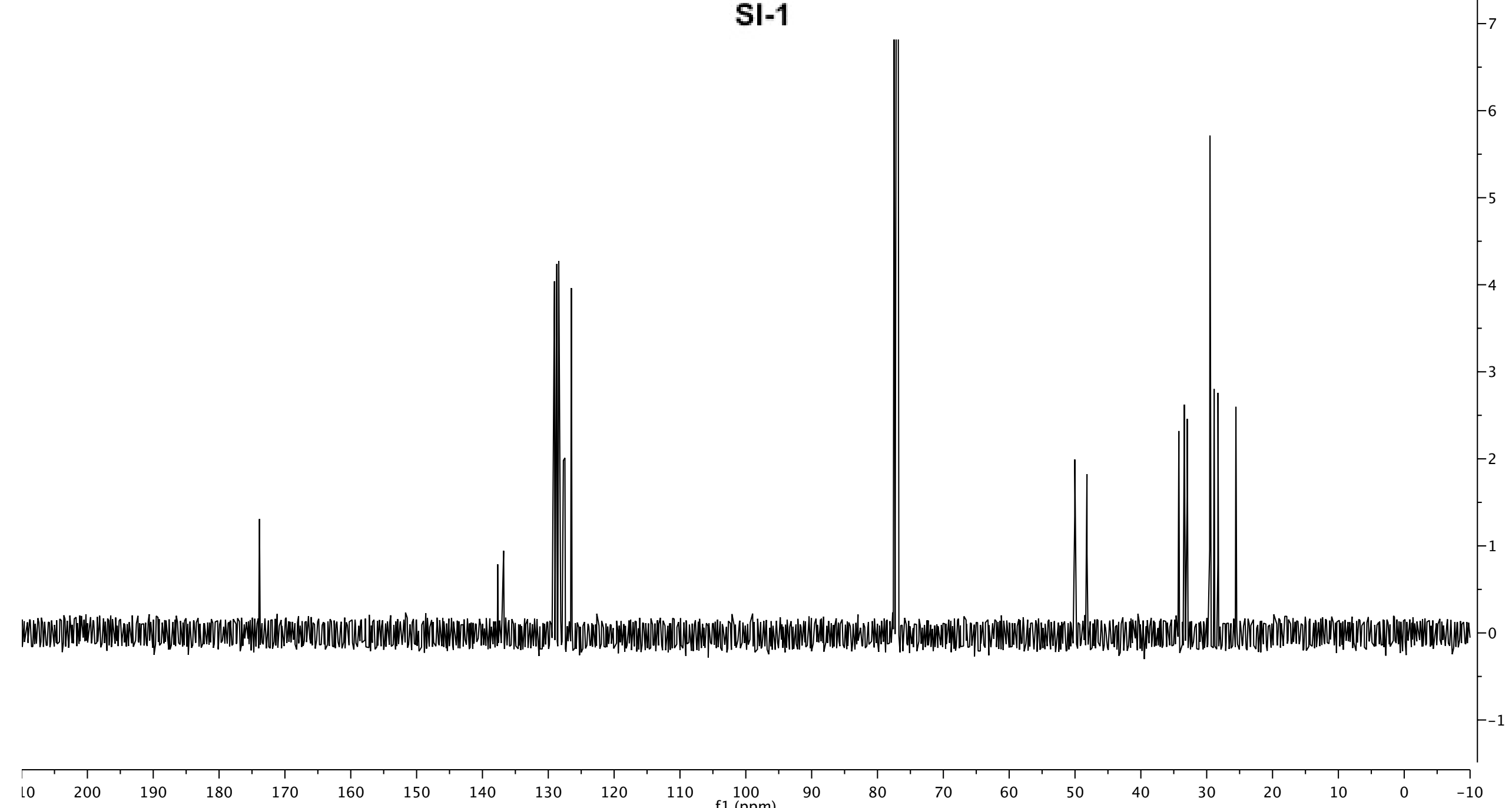
요 mm

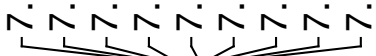

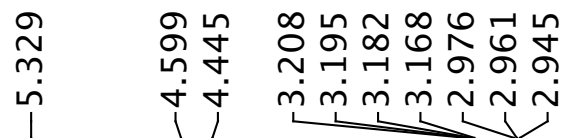

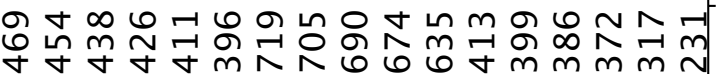

-

ન્નનન્નન- ન્

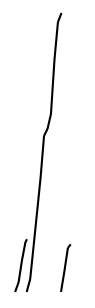<smiles>CCCCC(=O)CCCNC(=O)CCc1ccccc1</smiles>

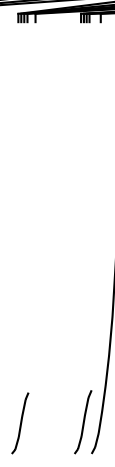

1 af

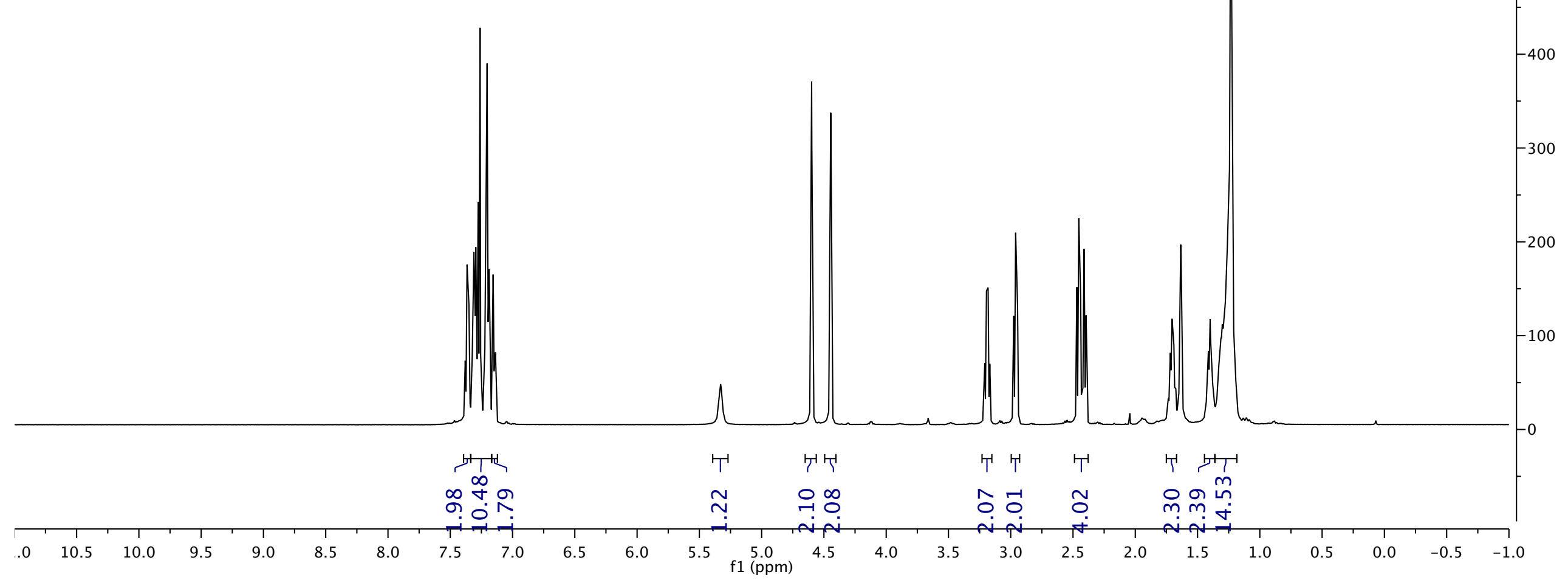


<smiles>CCCCC(=O)CCCNC(=O)CCc1ccccc1</smiles>

1 af

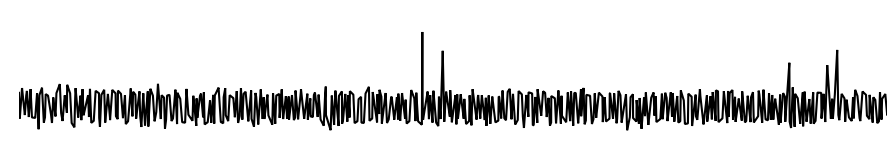
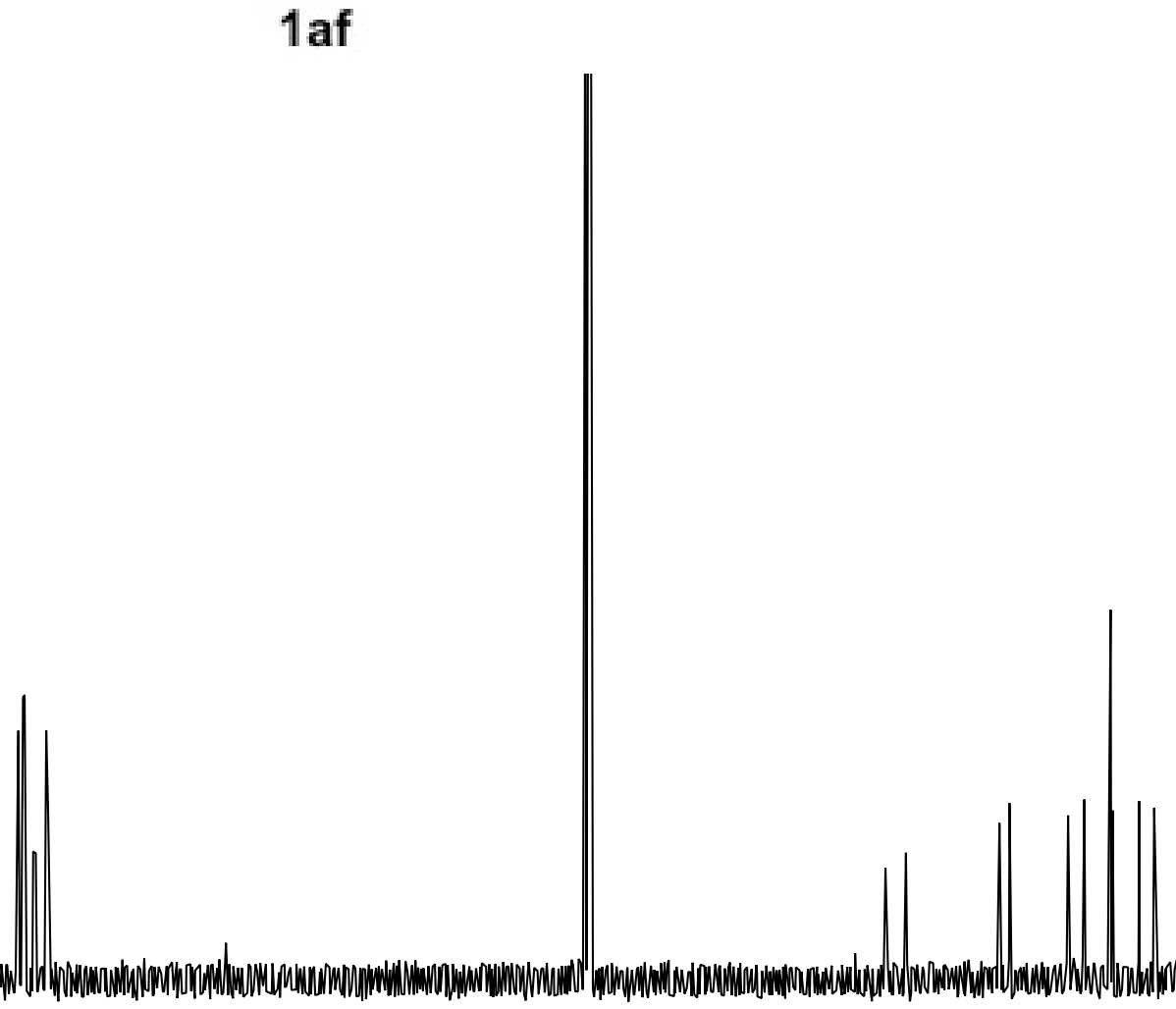


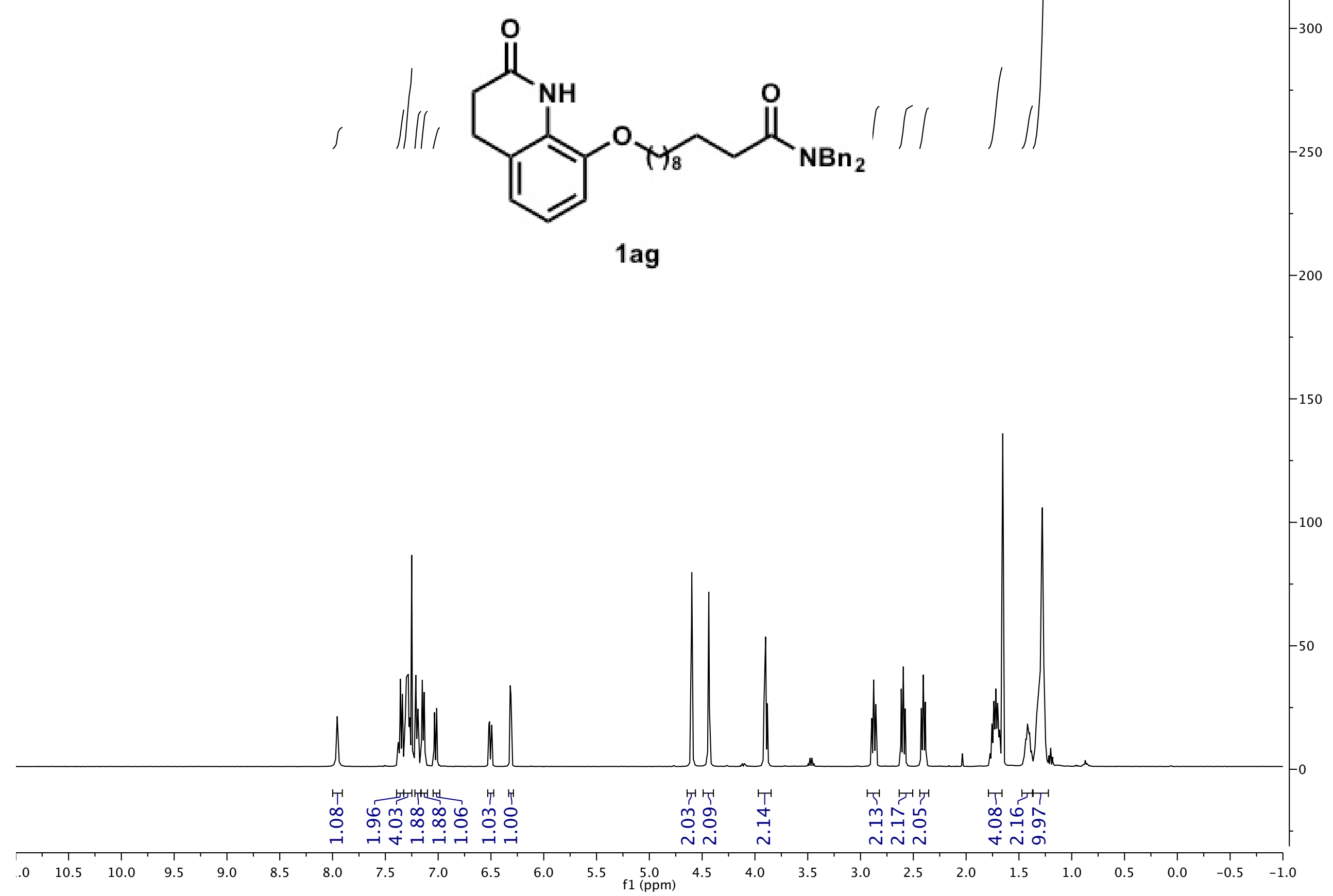




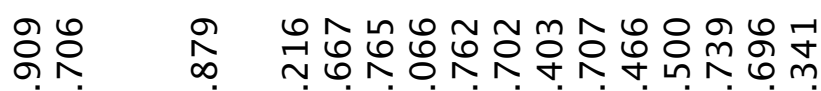

mi

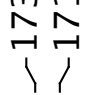

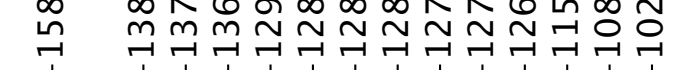

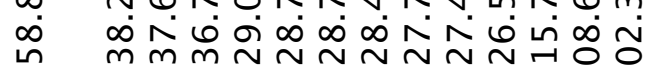

$\frac{m}{U} \frac{m}{v} \frac{m}{v}$

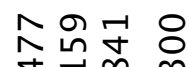

N

ヘヘペ

i<smiles>CCCCC(=O)CCCOc1cccc2c1NC(=O)CC2</smiles>

$1 \mathrm{ag}$

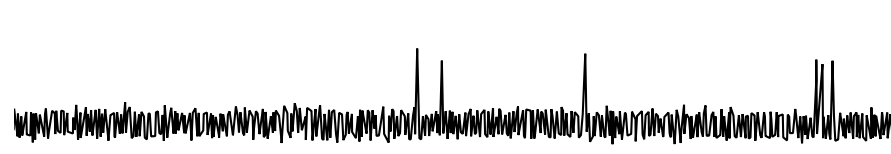

$$
\text { || }
$$

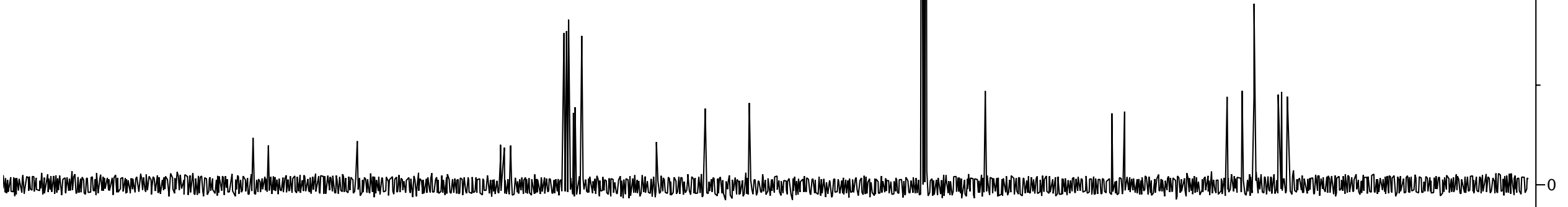




$$
\text { | }
$$
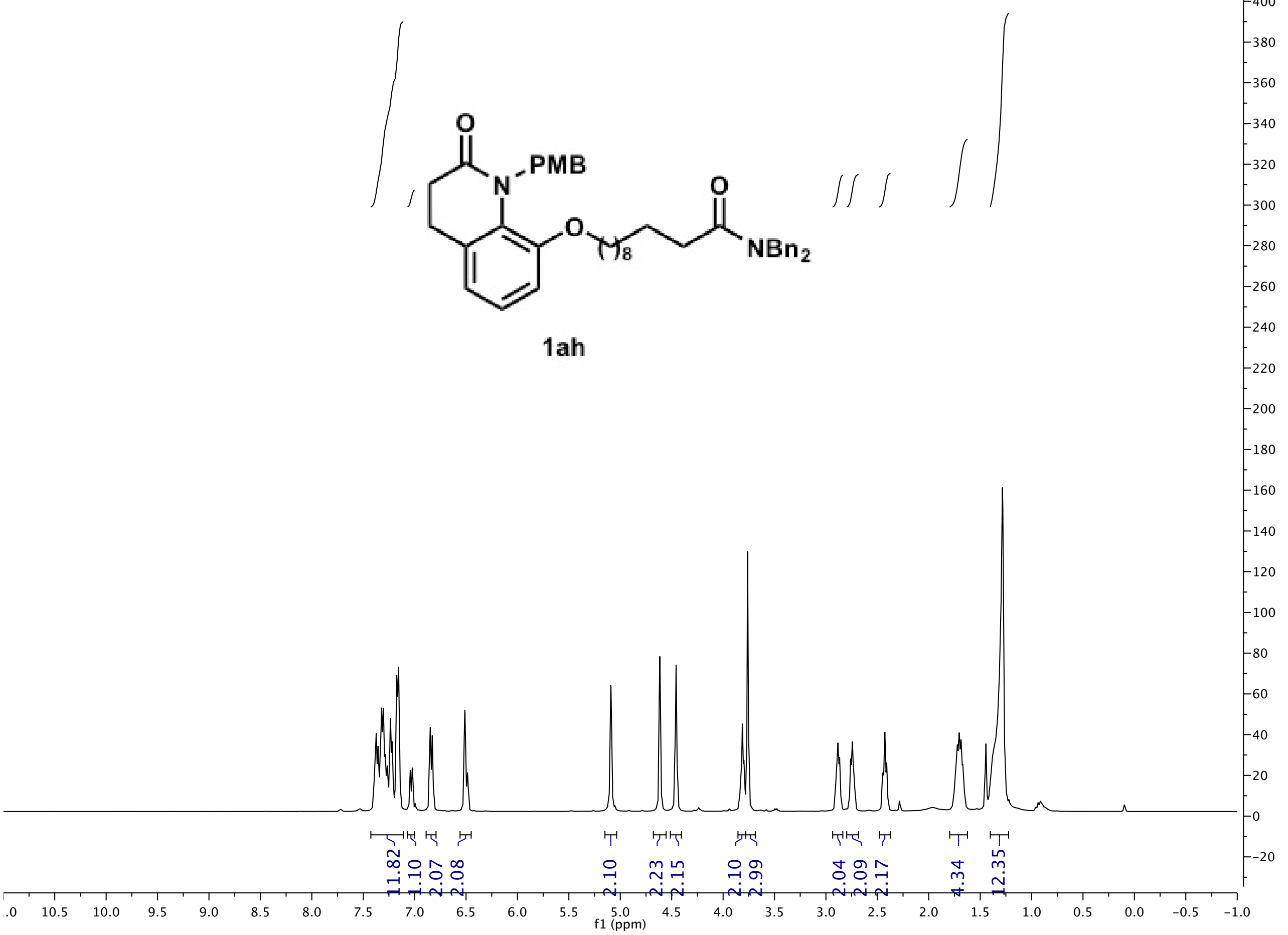


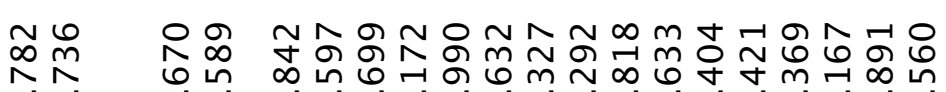

mio

r

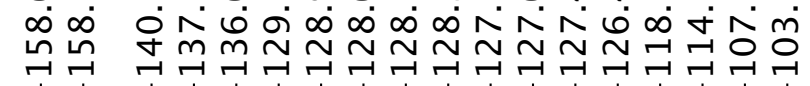

$\longrightarrow$ $\underline{\underline{u}} \frac{m}{\mathrm{u}} \frac{m}{\mathrm{i}} \frac{\mathrm{m}}{\mathrm{u}}$

กำ

송ㅇํ

|

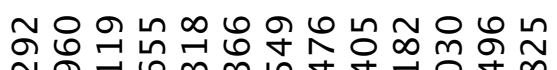

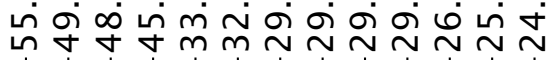

约<smiles>CCCCC(=O)CCCCOc1cccc2c1N(C(C)(C)C)C(=O)CC2</smiles>

1ah 


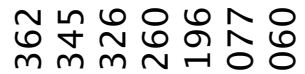
NNNNNN

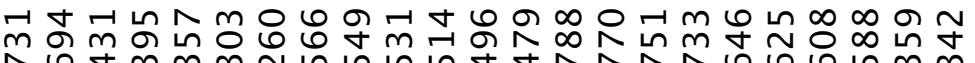
$\wedge 6 \forall m m m \sim$ เ

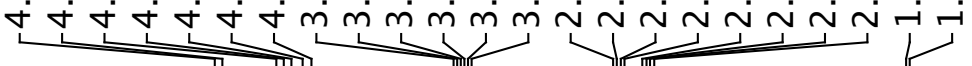

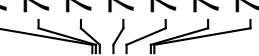

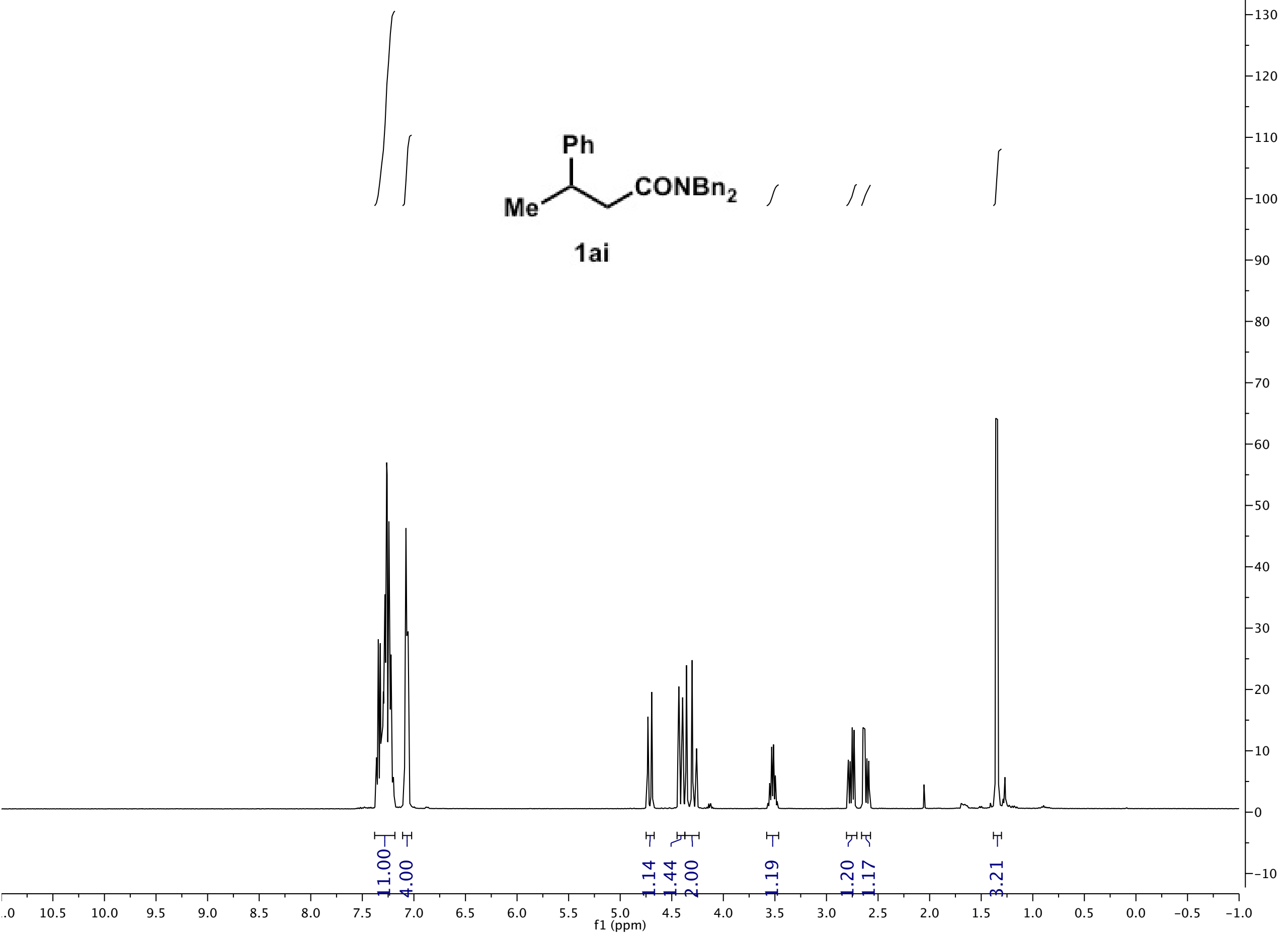



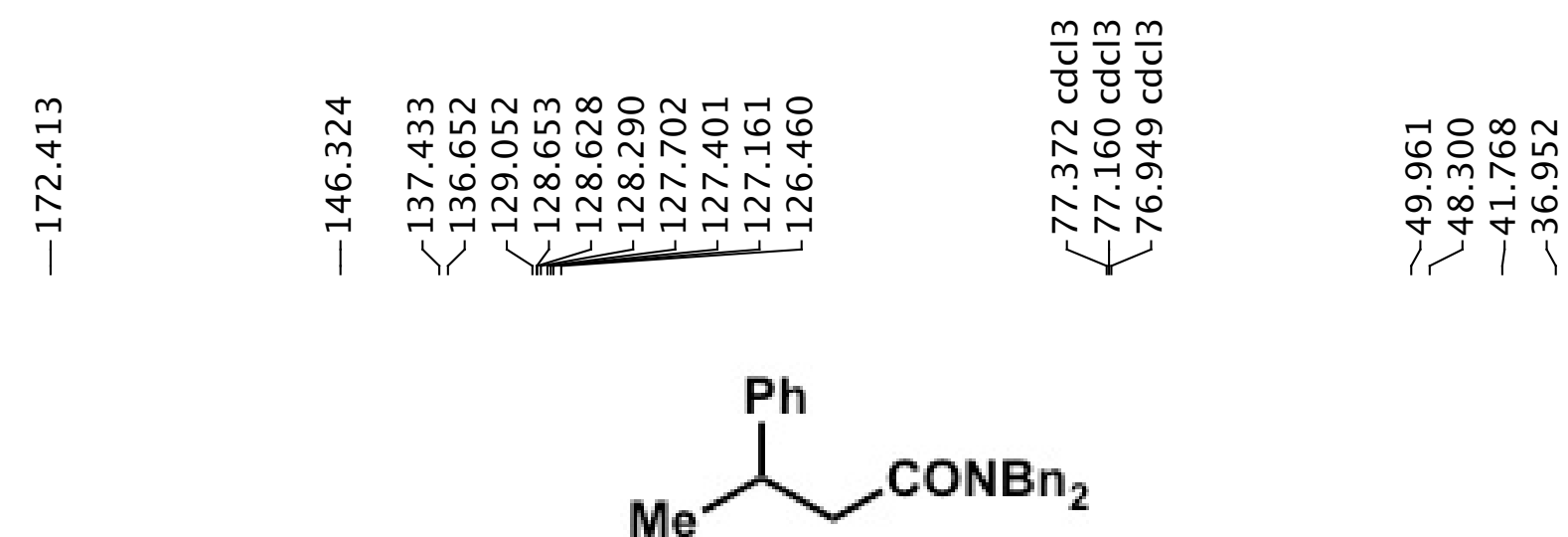

1 ai

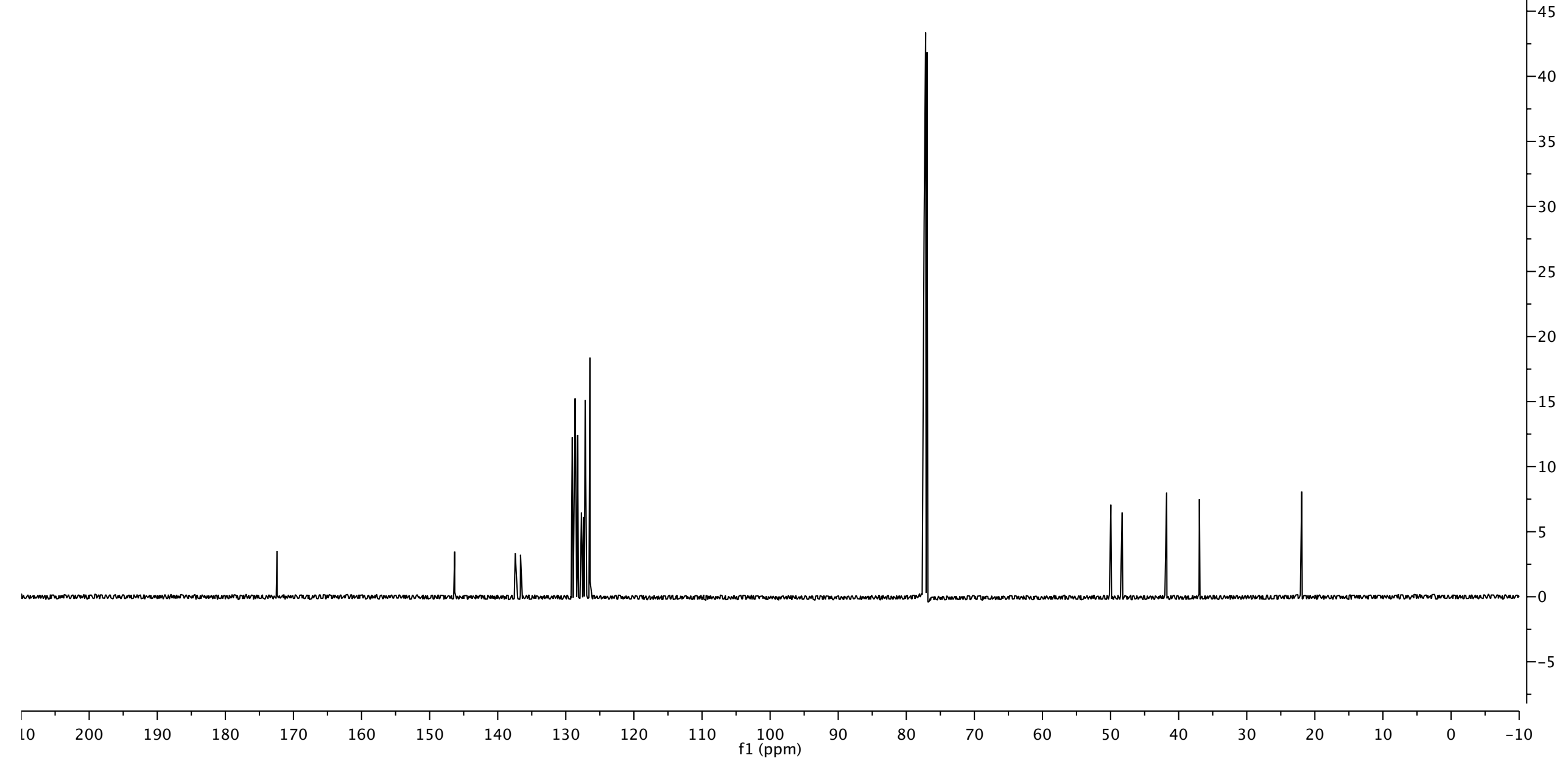




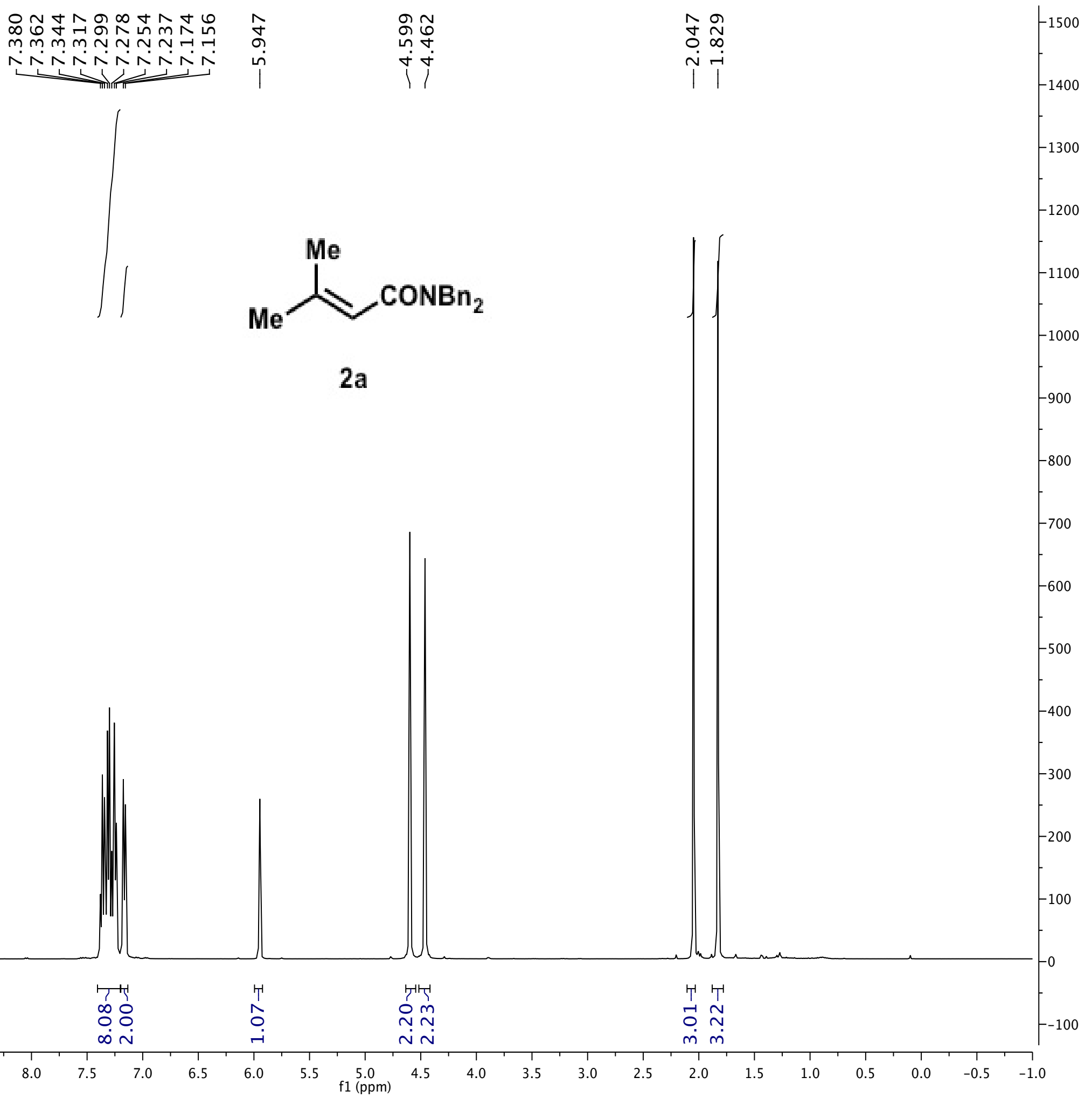



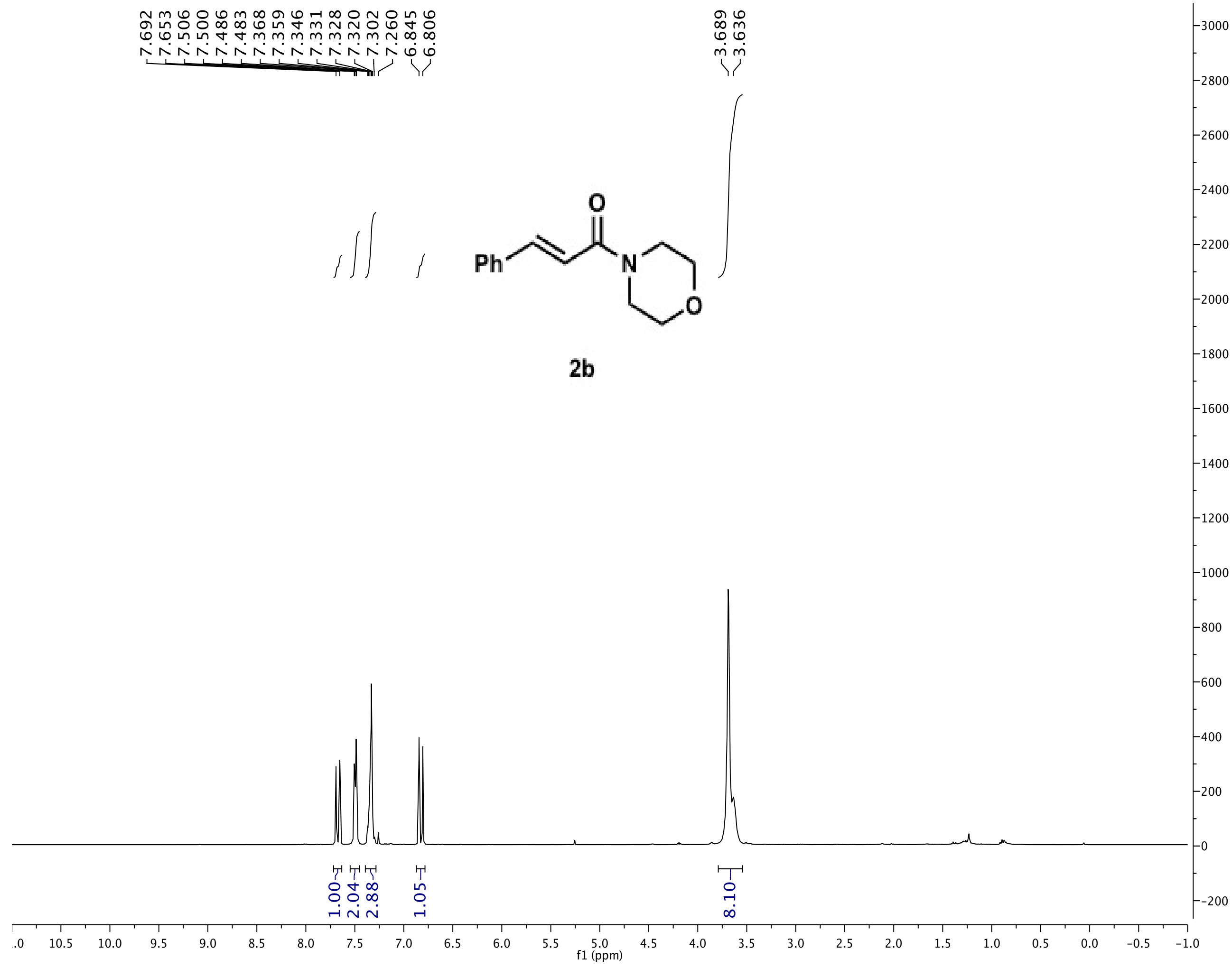


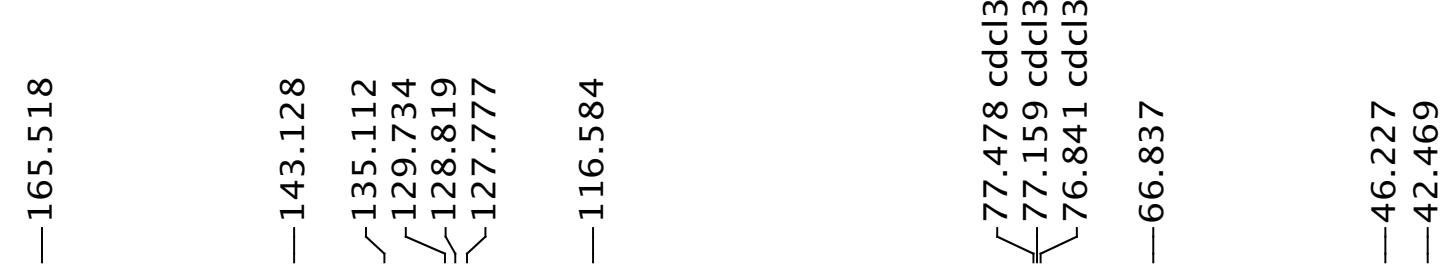

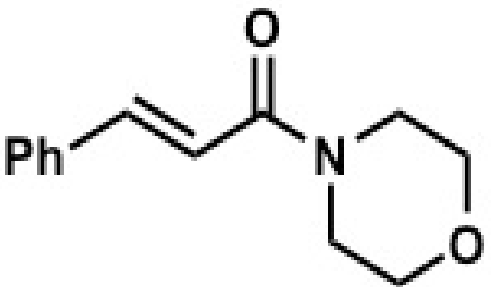

2b 


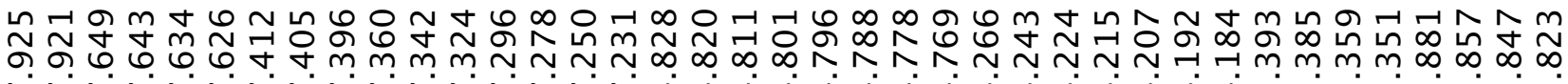

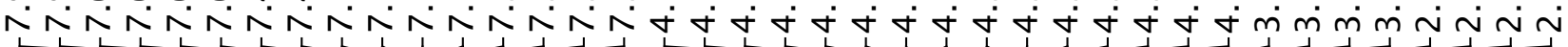
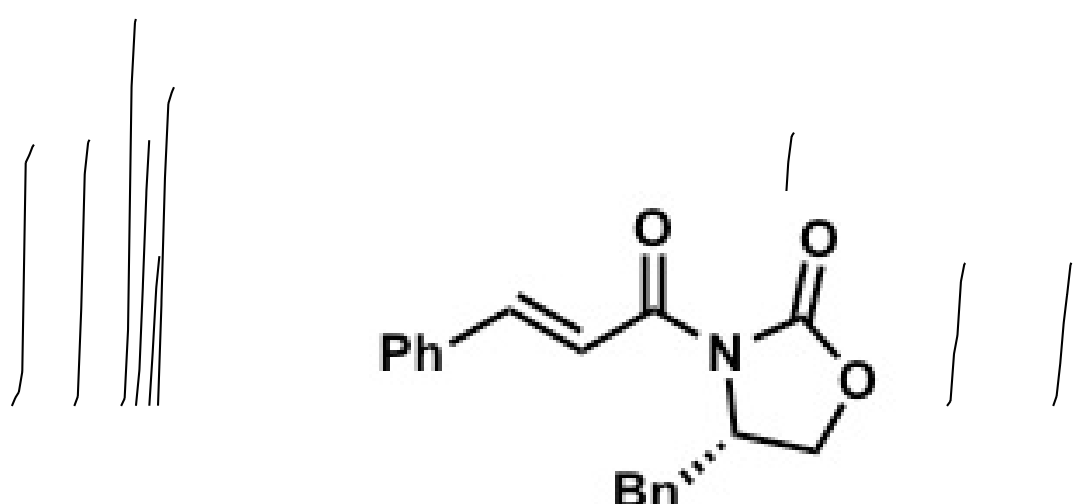

$-2000$

2c

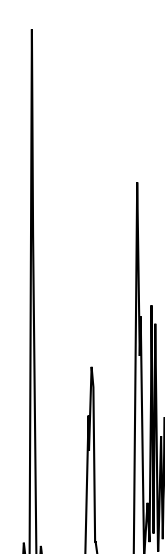

上1

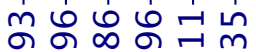

- 
<smiles>O=C(/C=C/c1ccccc1)N1C(=O)OC[C@H]1Br</smiles>

2c

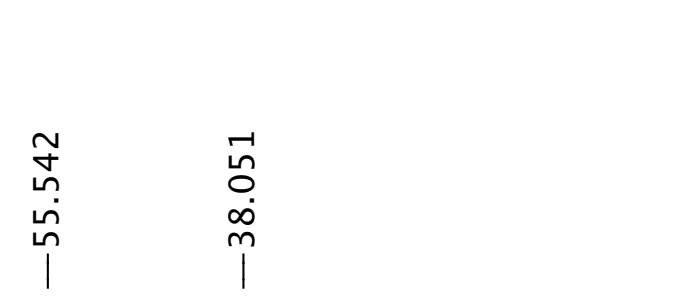

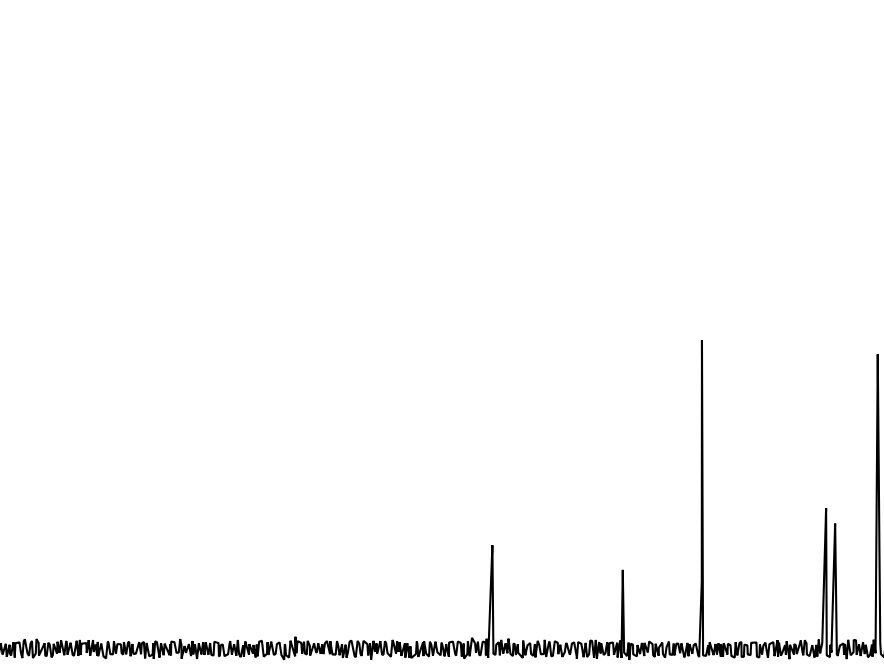




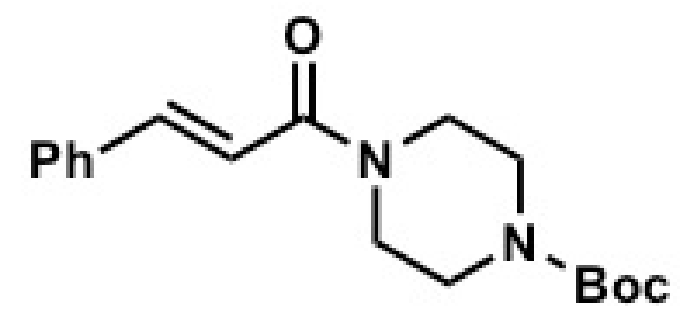

2d

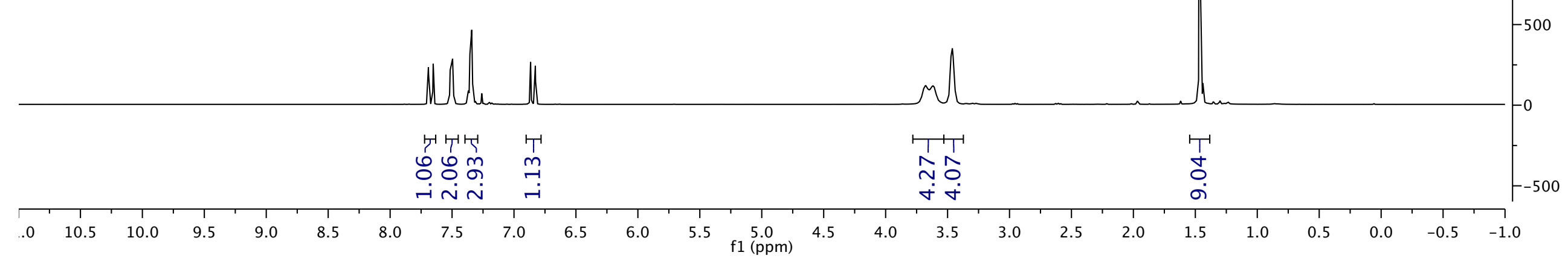




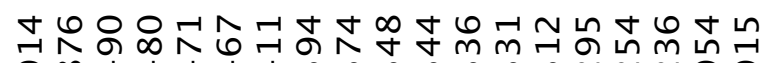

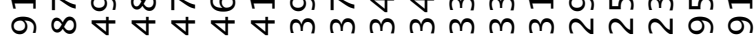

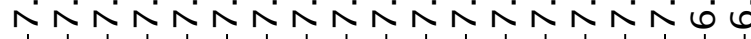
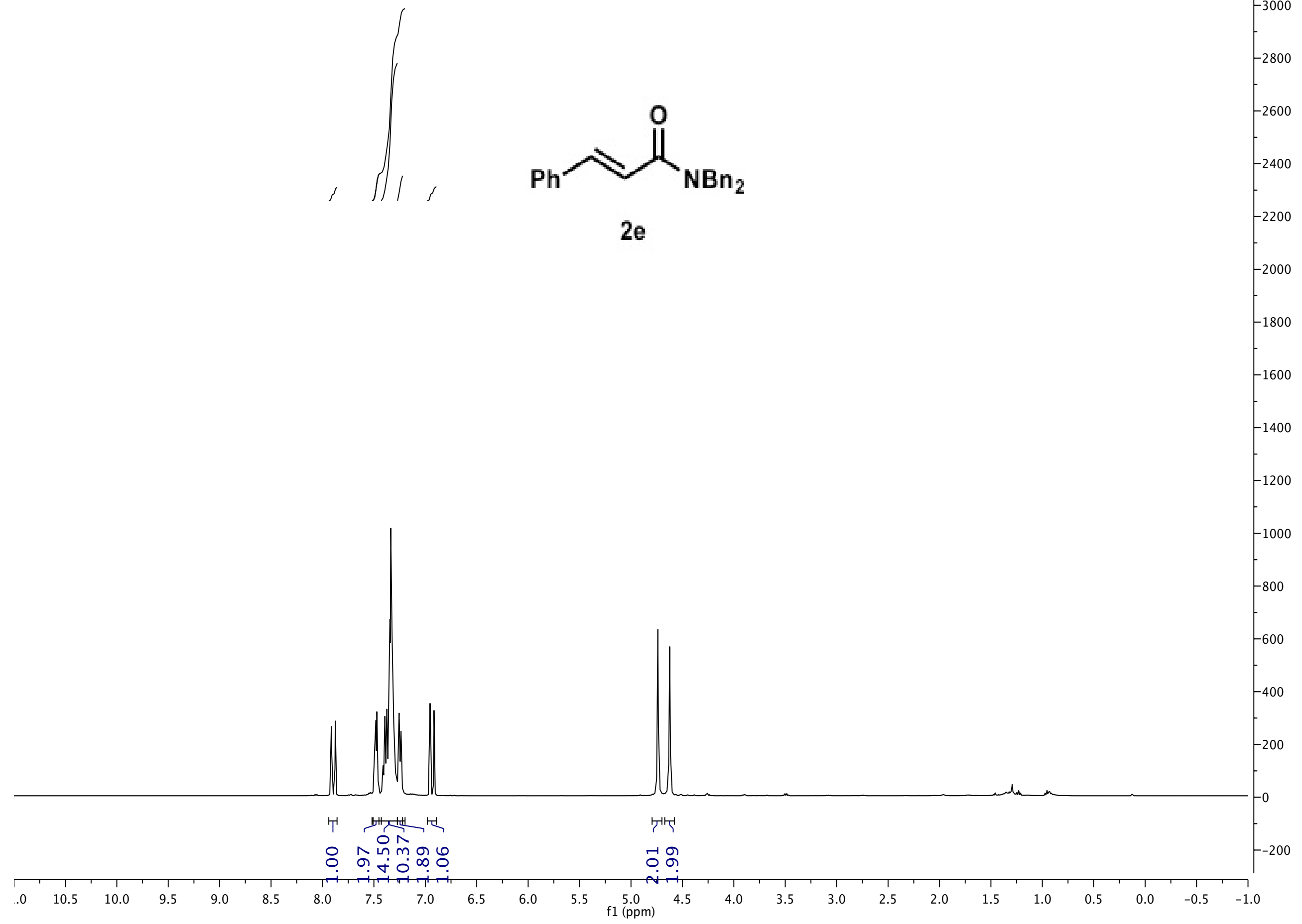


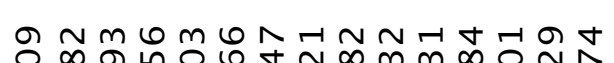

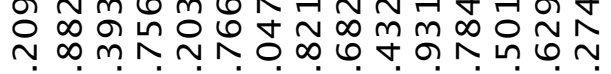

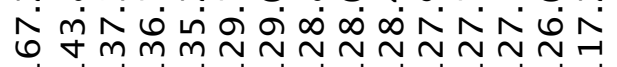

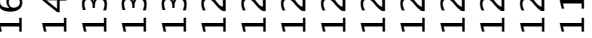<smiles>CC(C)(C)CN(C(=O)/C=C/c1ccccc1)c1ccccc1</smiles>

$2 \mathrm{e}$

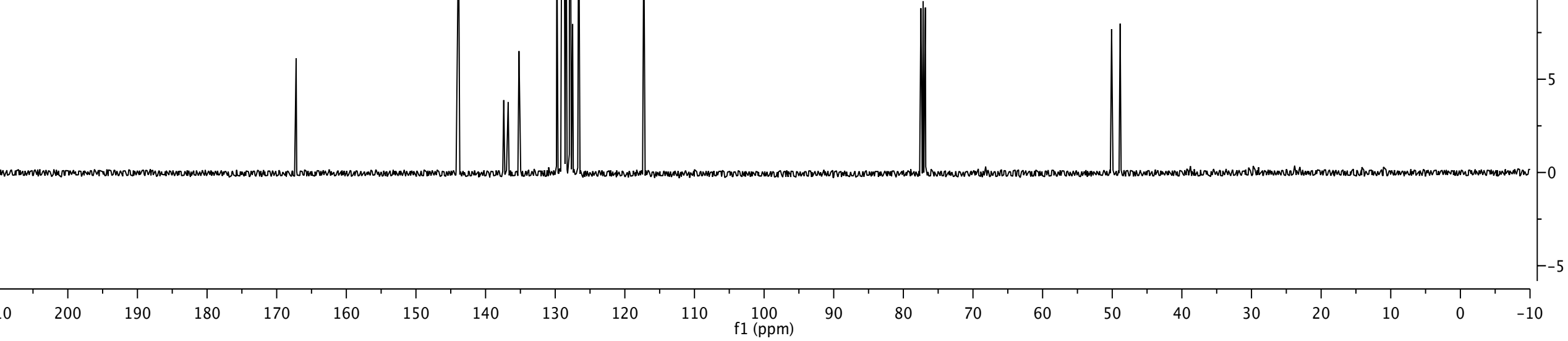




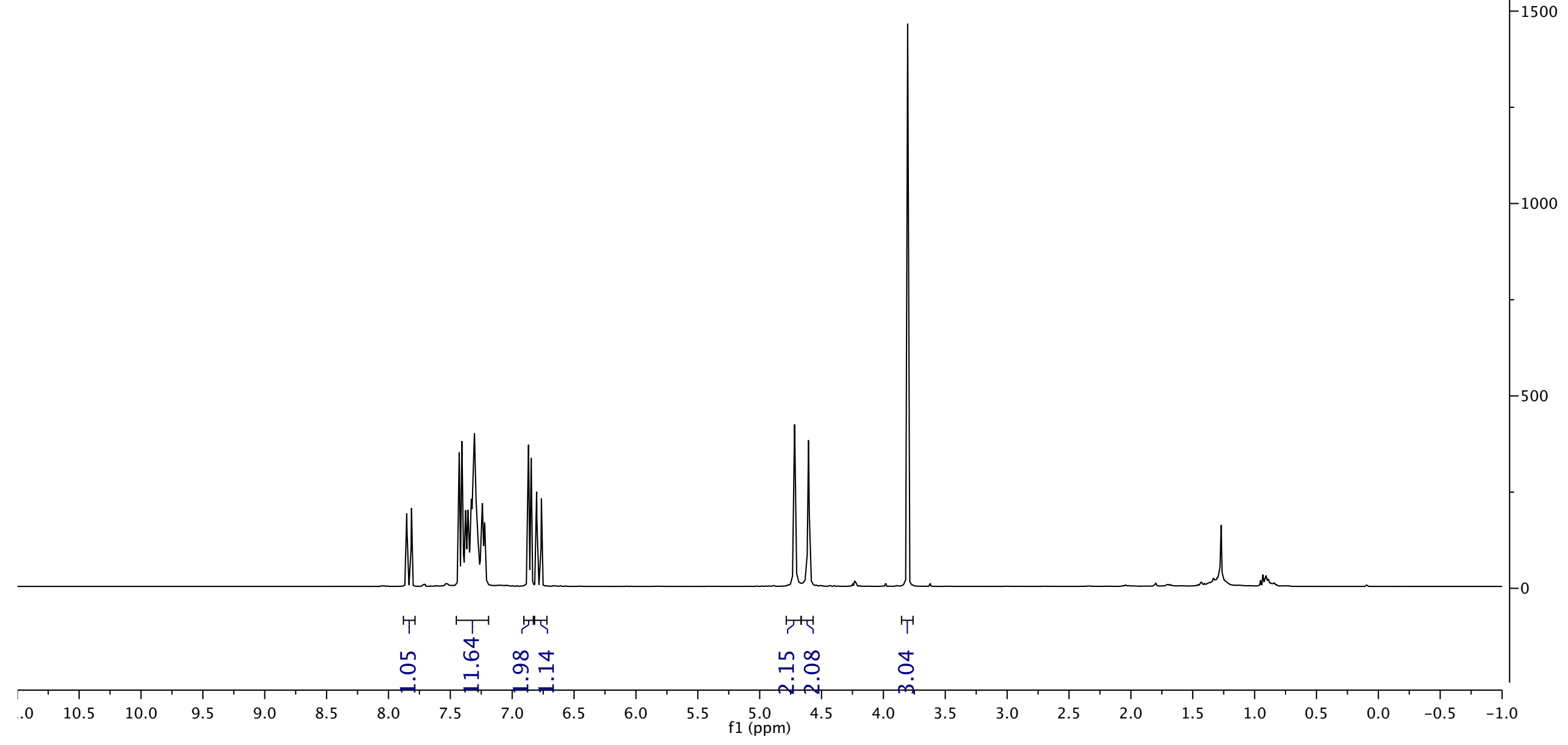


<smiles>CCCCC(=O)/C=C/c1ccc(OC)cc1</smiles>
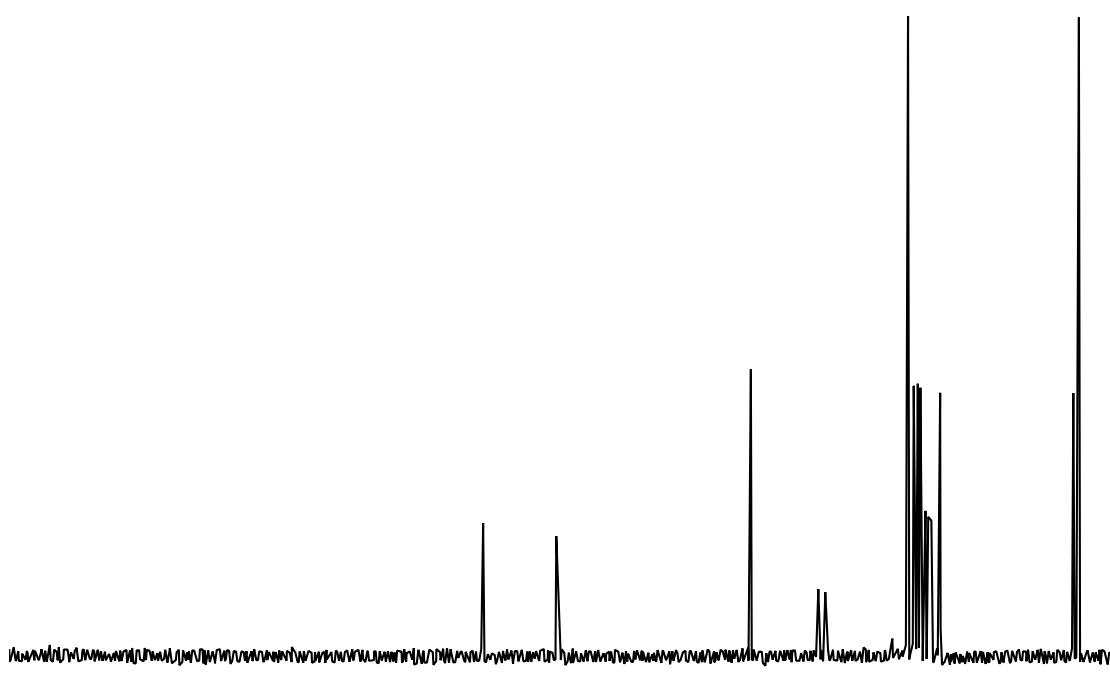


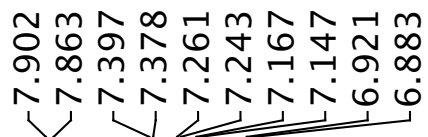

$\stackrel{\sim}{\sim}$

ก

ז广

$\stackrel{\substack{n \\ n}}{n}$
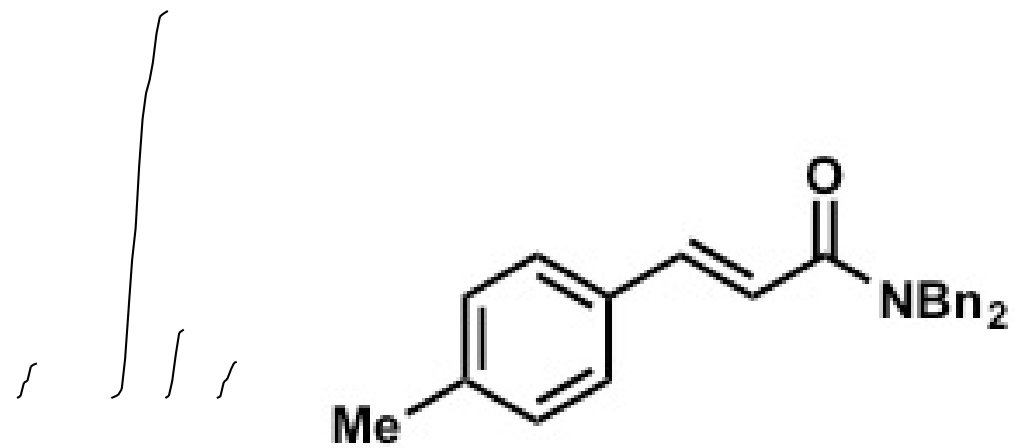

$2 \mathrm{~g}$

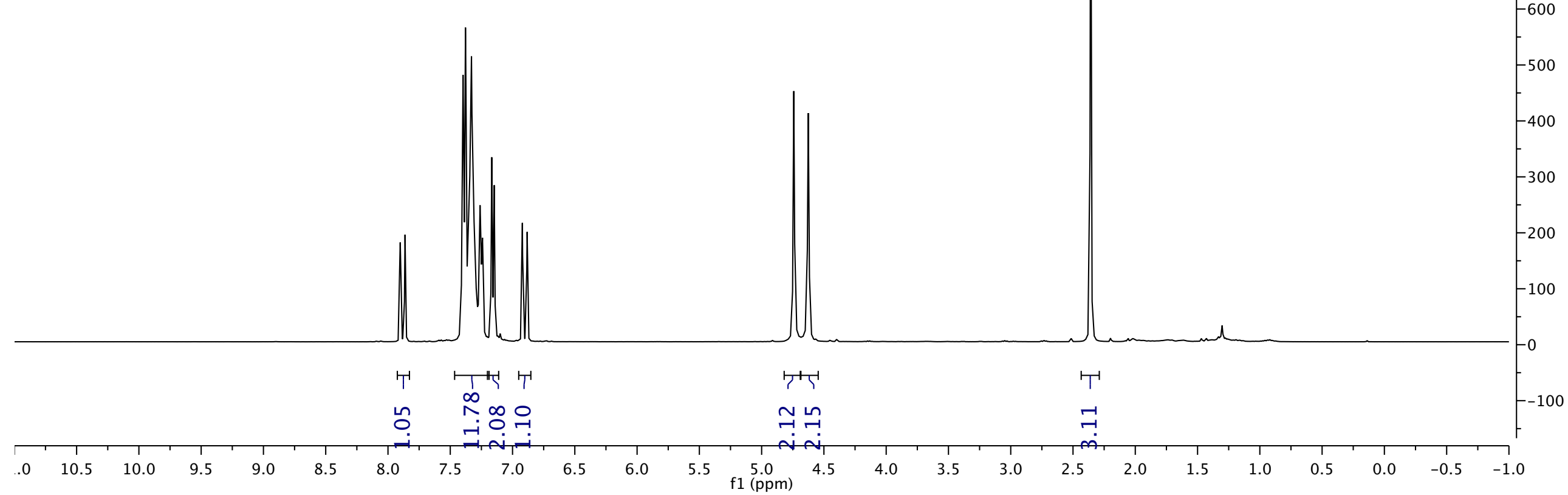




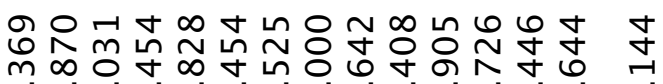

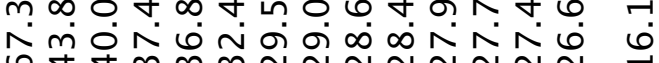

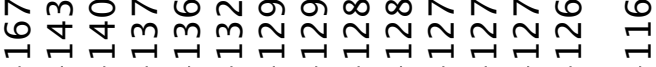

$\frac{m}{U} \frac{m}{v} \frac{m}{v}$

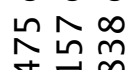

Nine

กヘ

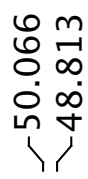

$\stackrel{\text { Ln }}{\stackrel{+}{+}}$

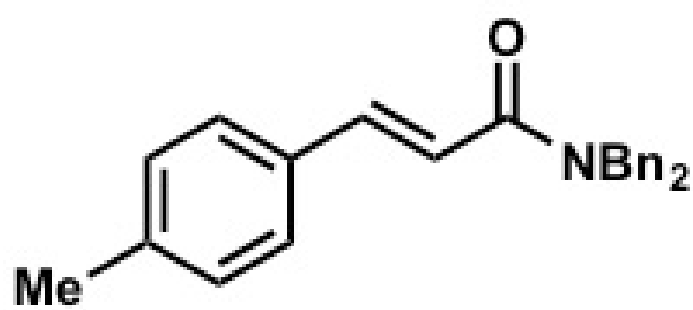

$2 \mathrm{~g}$ 

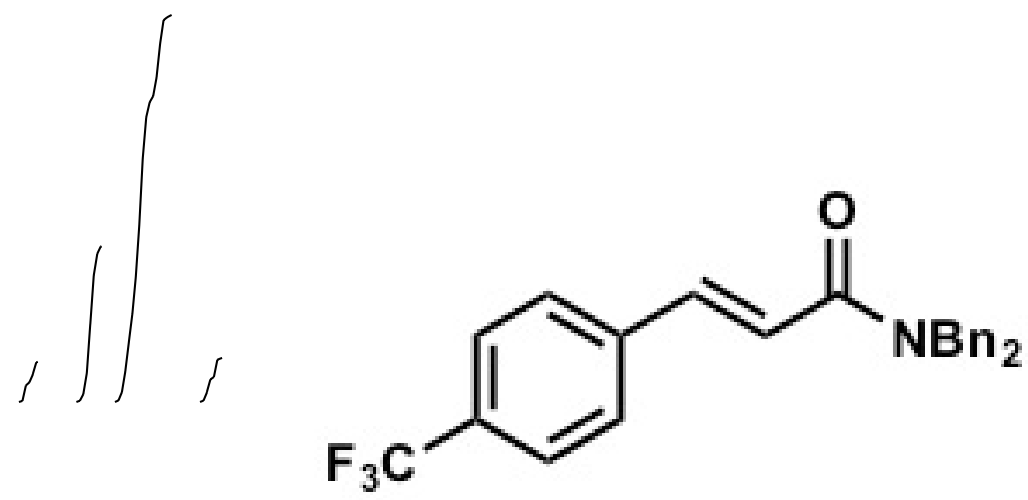

2h

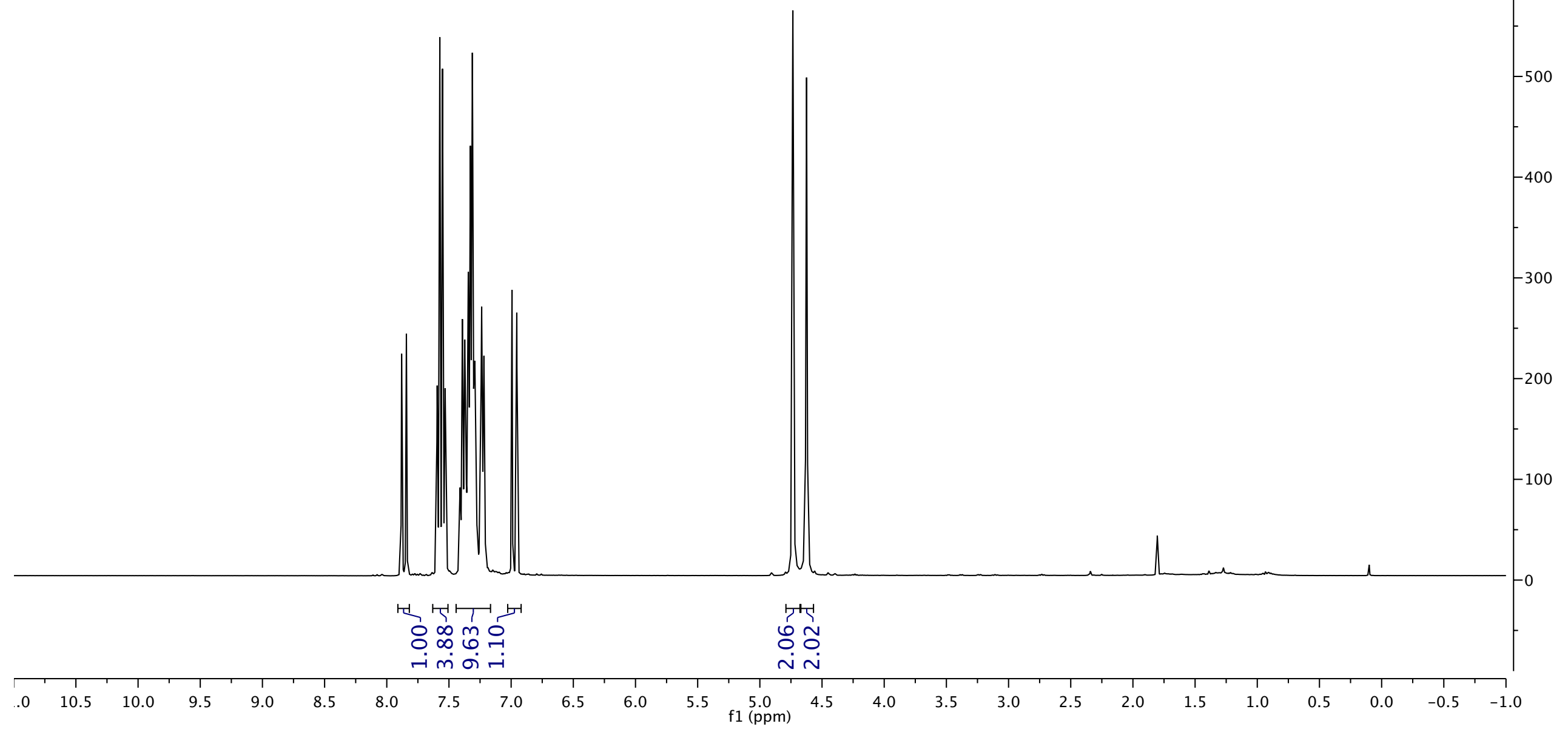




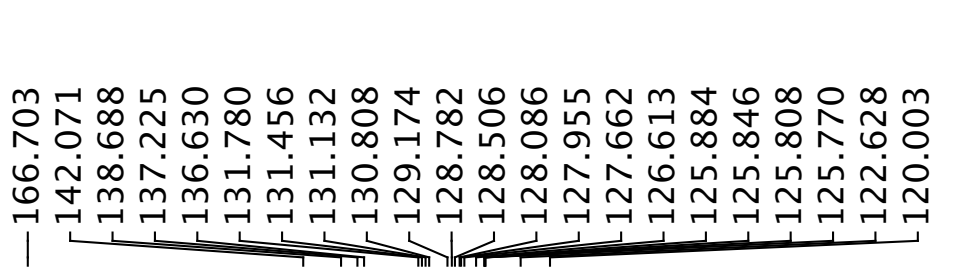<smiles>CCCCC(=O)/C=C/c1ccc(C(F)(F)F)cc1</smiles>

\section{2h}




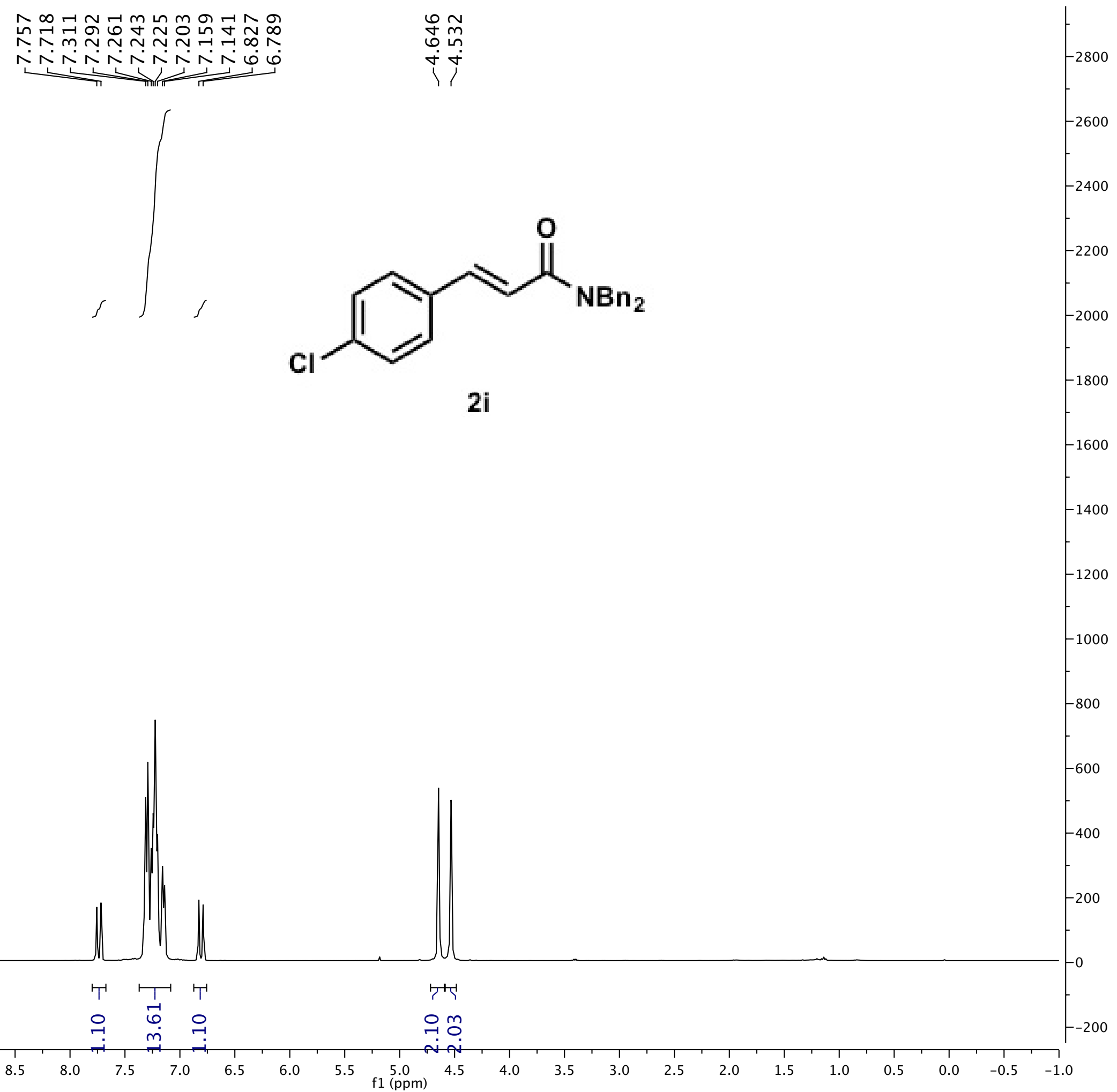




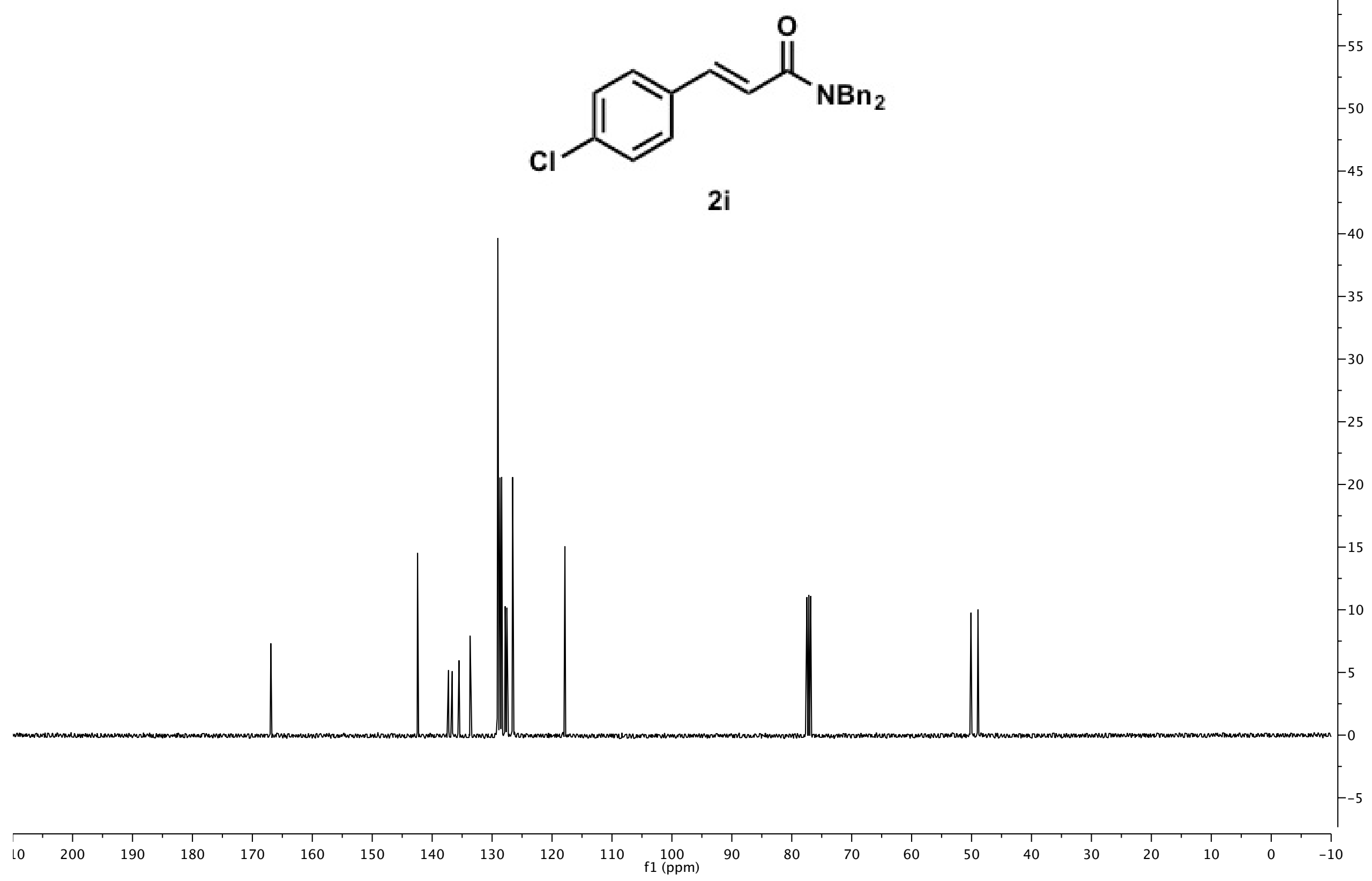



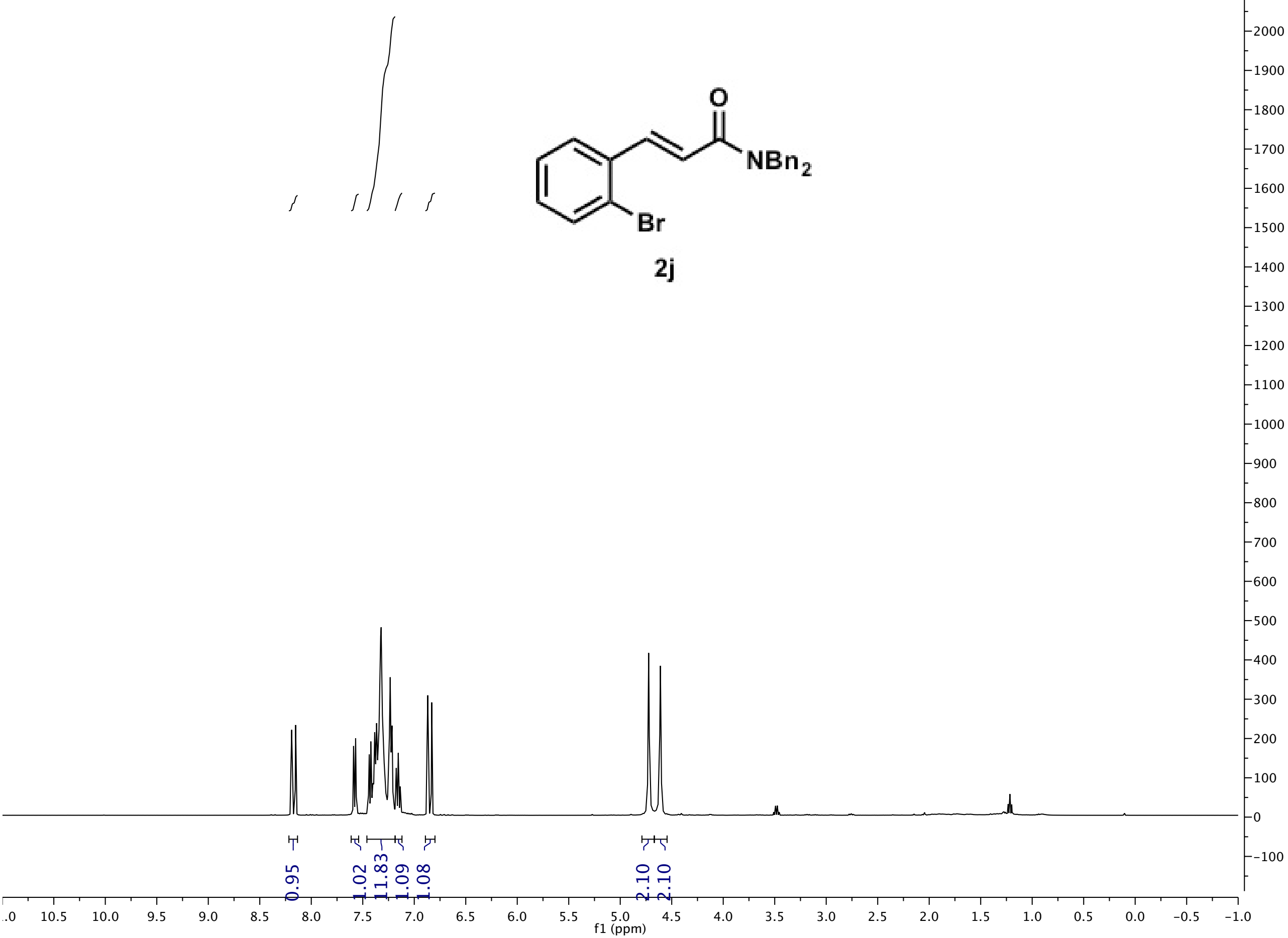

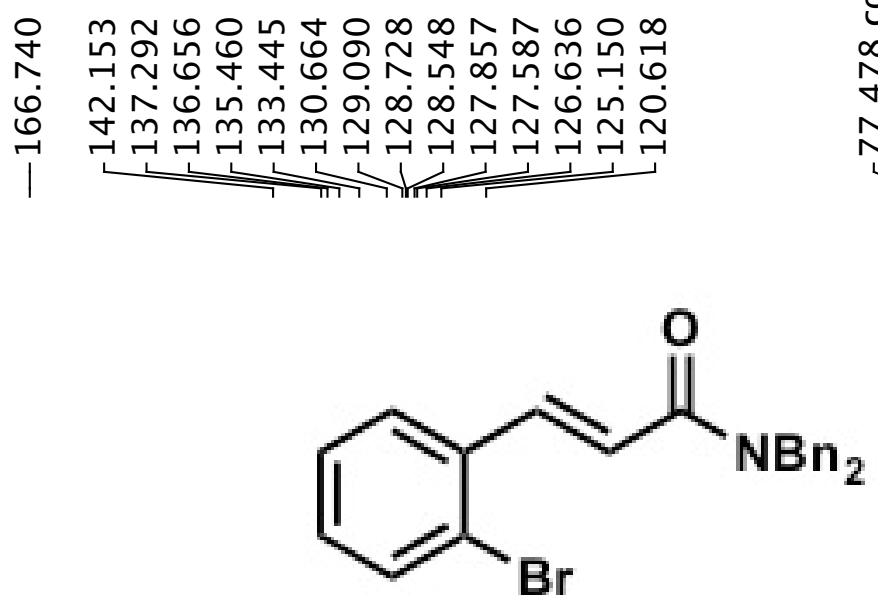

ดิ

i̊ 


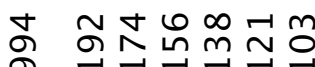



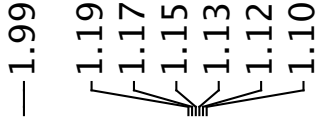
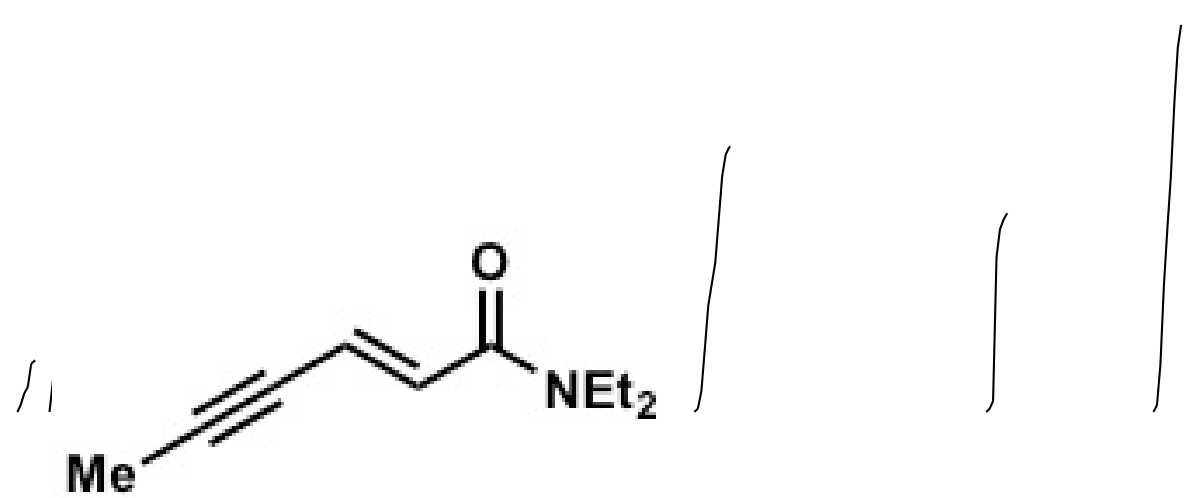

2k

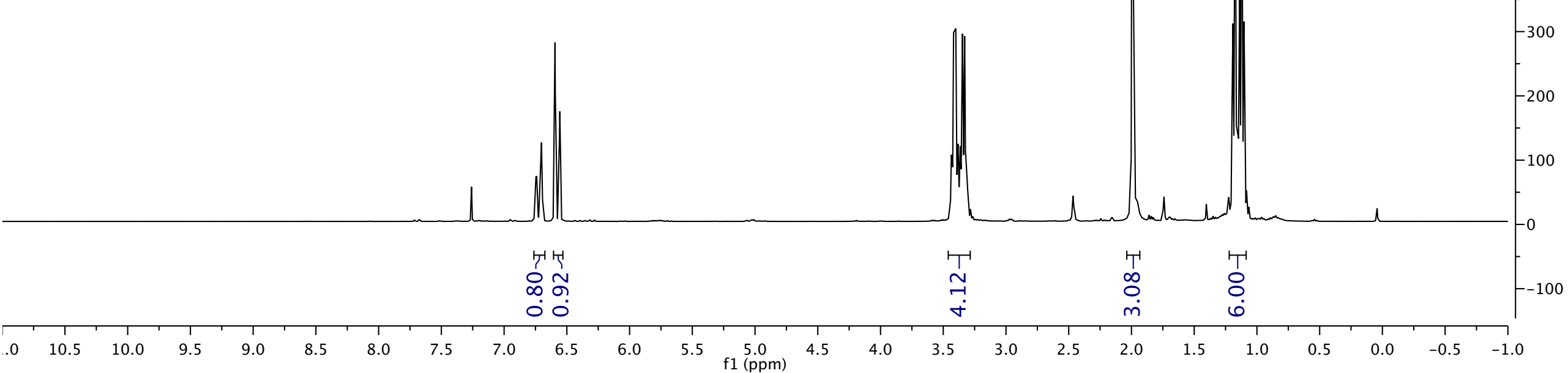




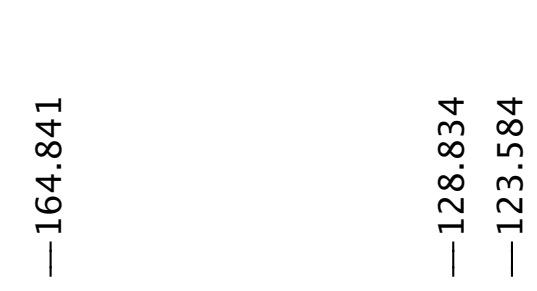

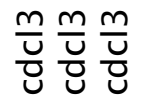

$\infty$ ᄂ

$\stackrel{\infty}{\underset{1}{*}} \underset{\mid}{\stackrel{\sim}{\sim}}$

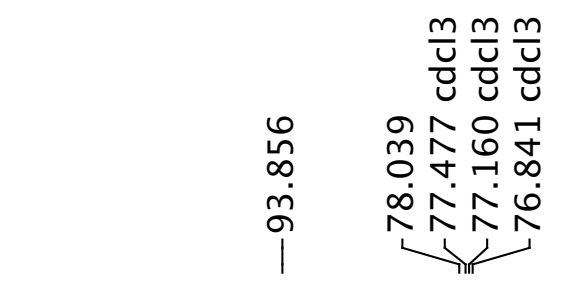



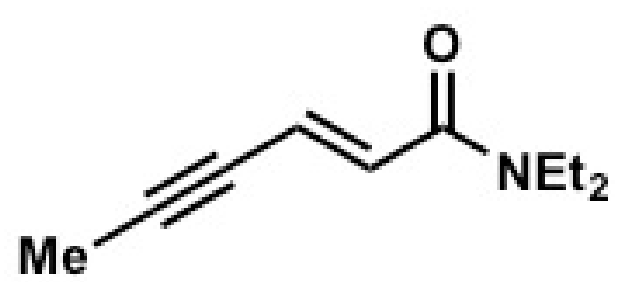

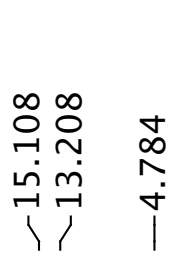



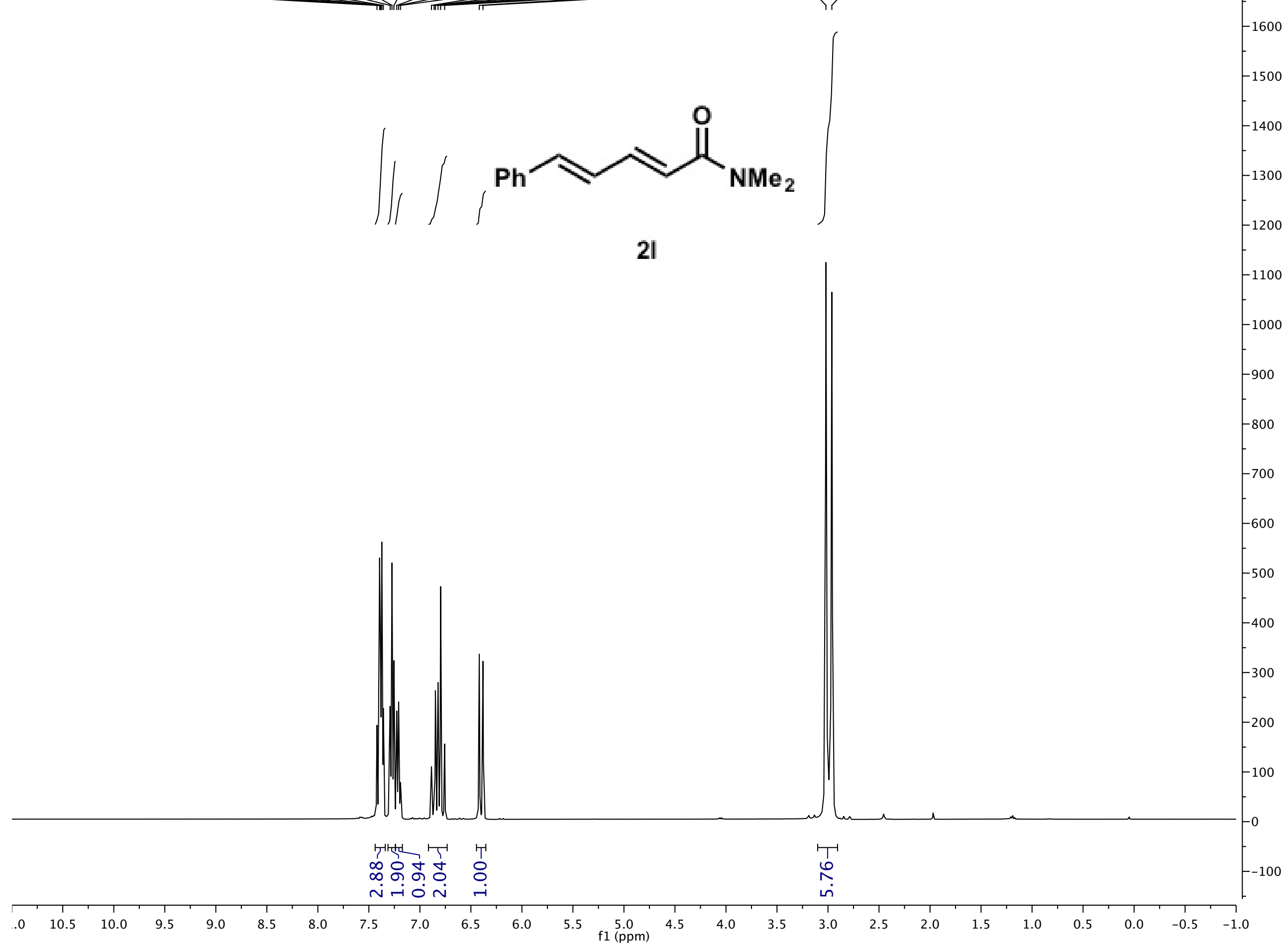


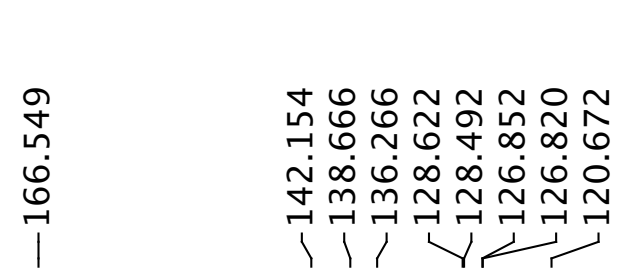

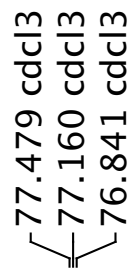

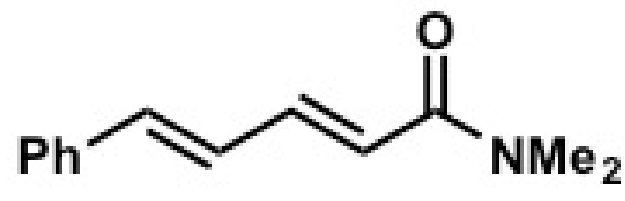

2I

\section{$\mathrm{NMe}_{2}$}

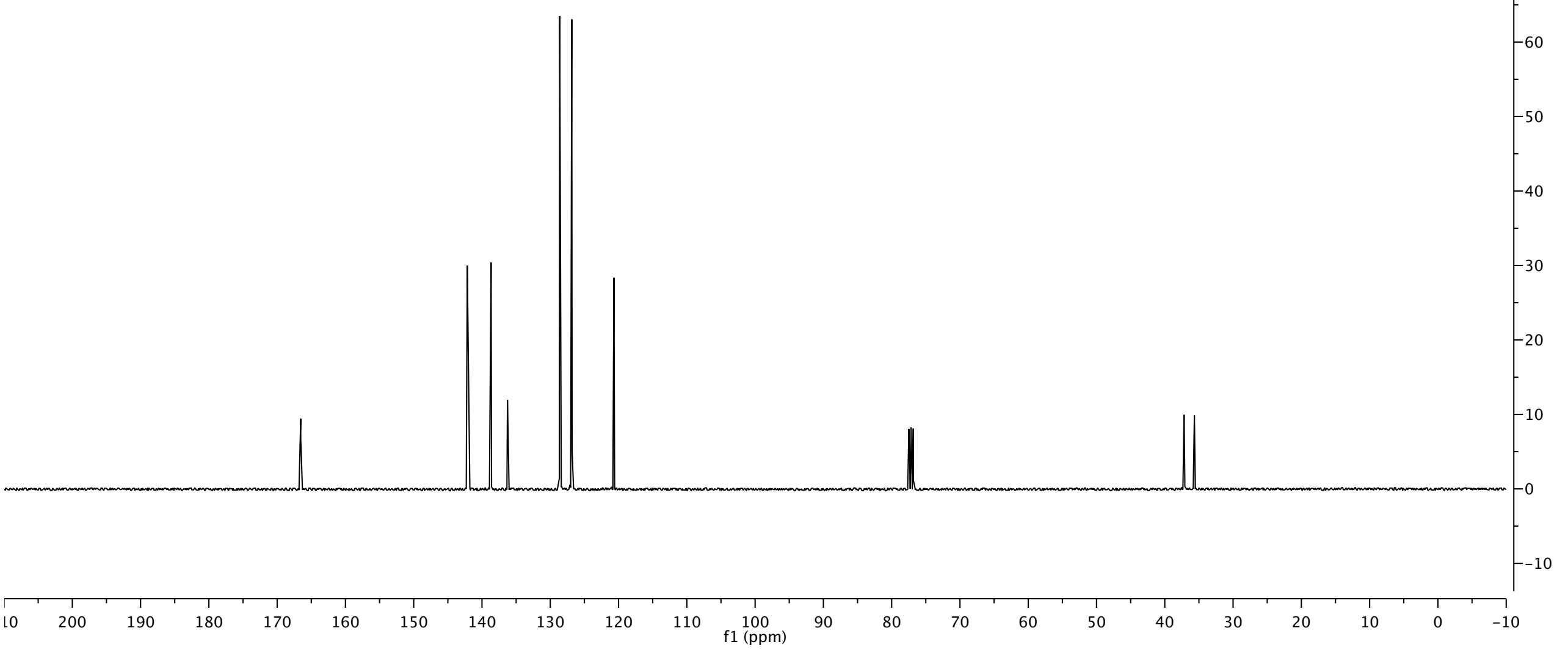



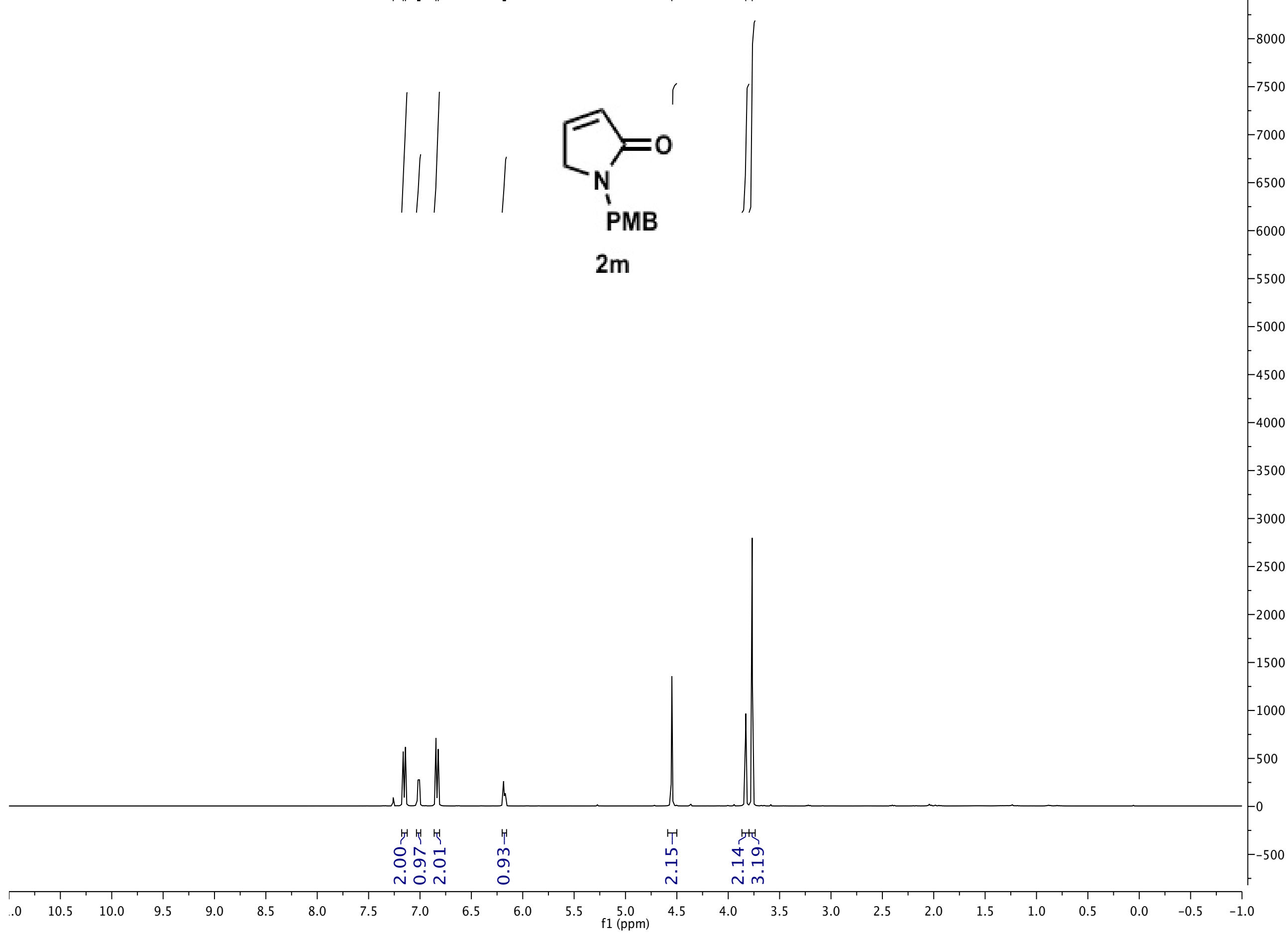

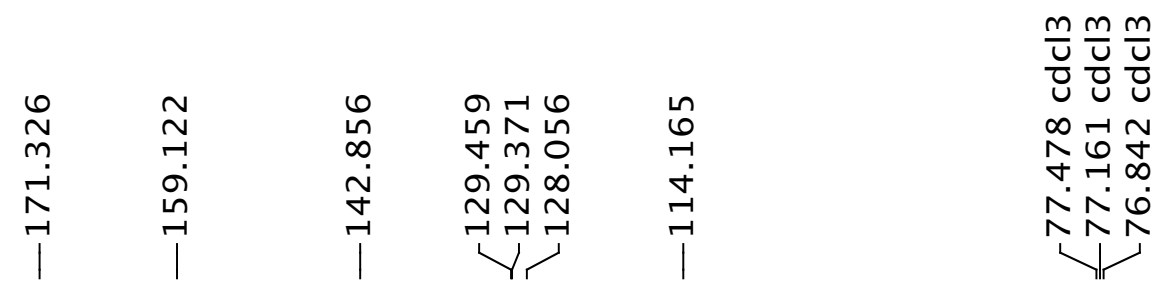

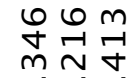

เก่ กิ่

NN

!।

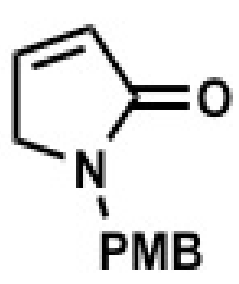

$2 \mathrm{~m}$

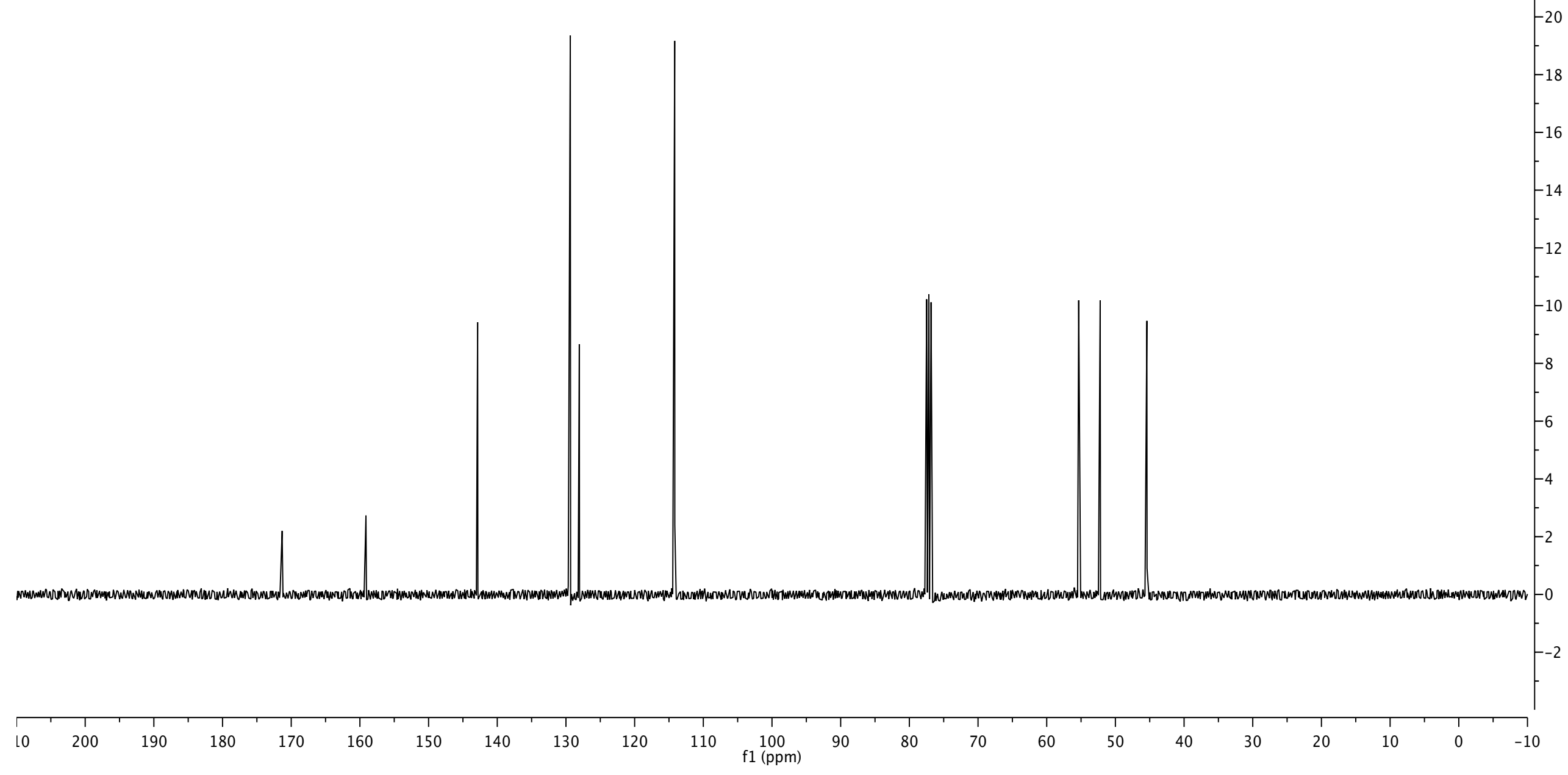



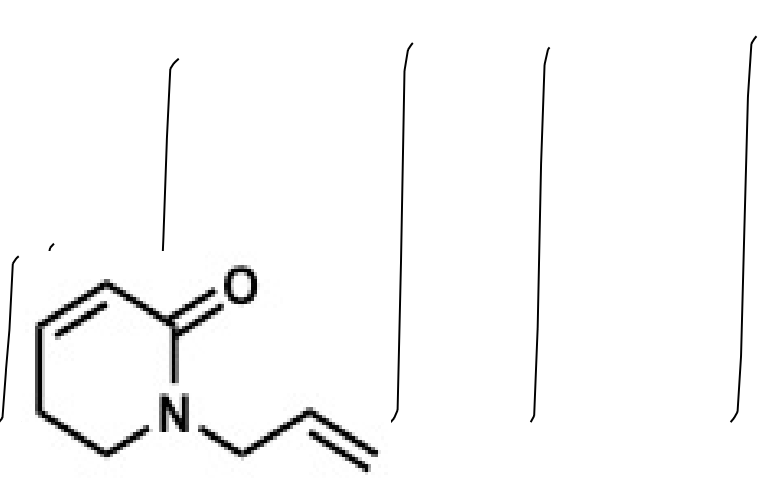

$2 n$

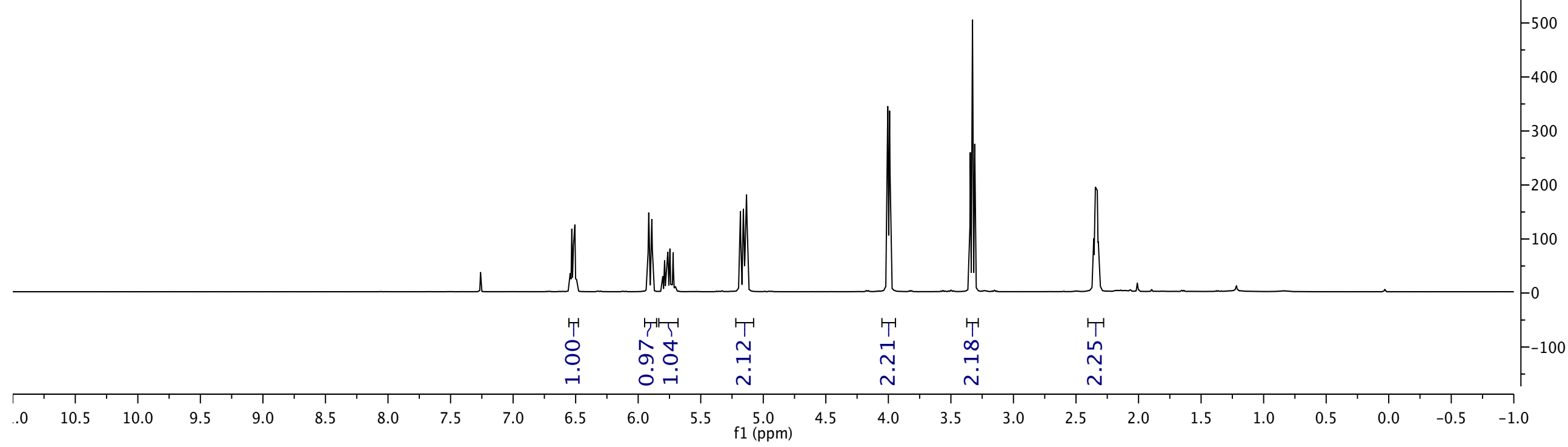



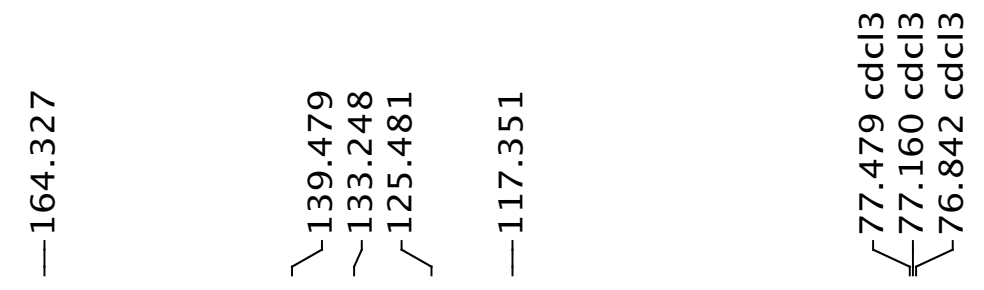

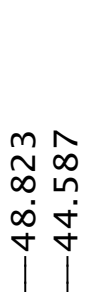

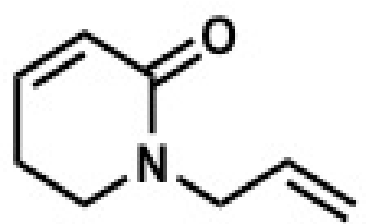




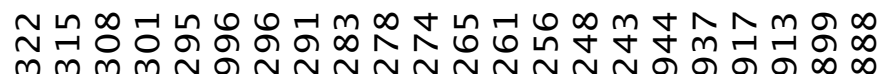
$1+1$

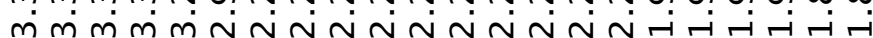

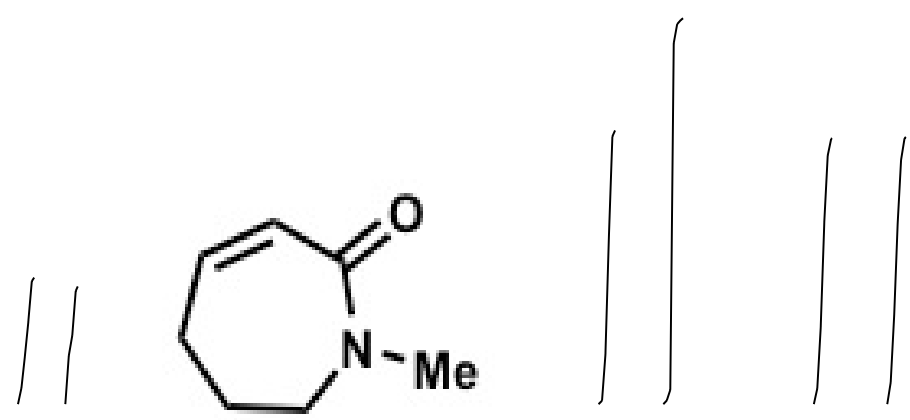

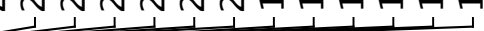

20

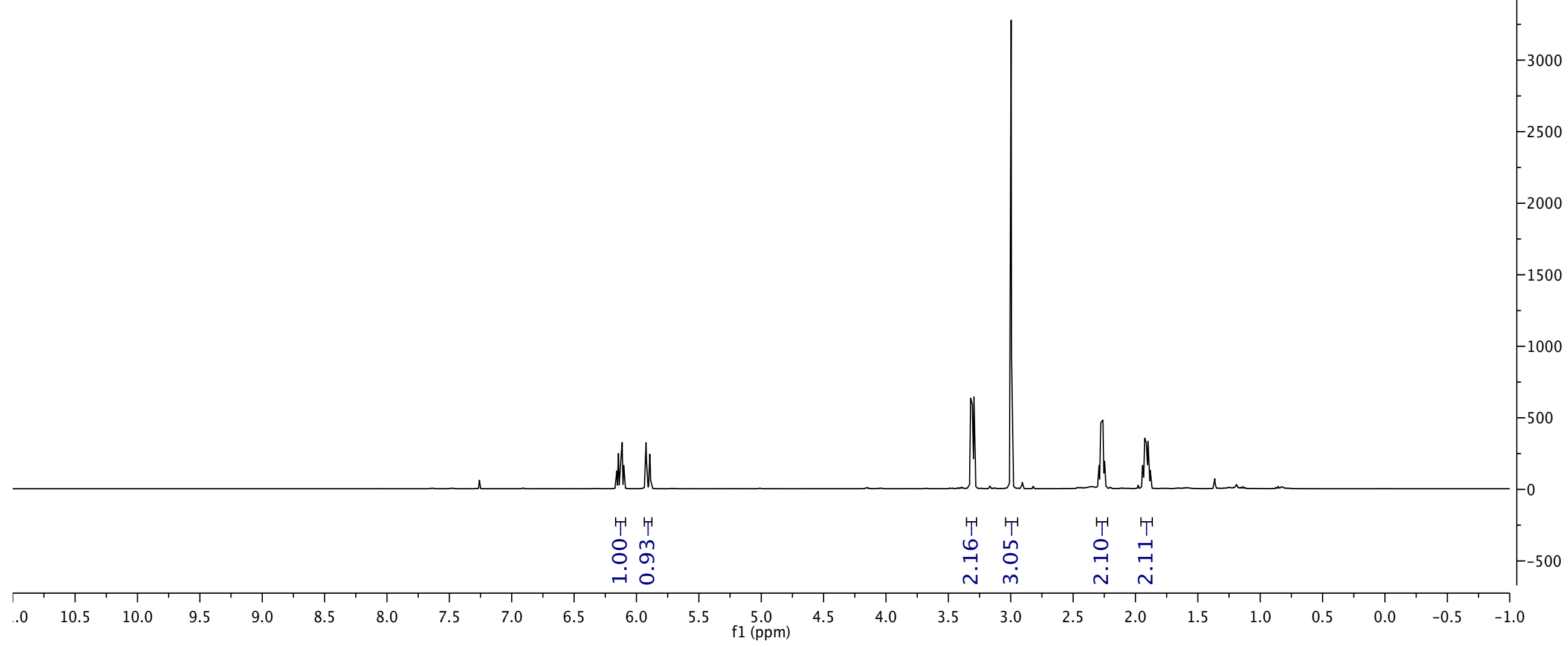




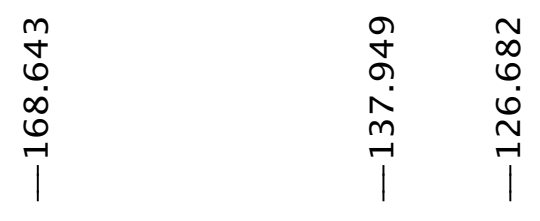

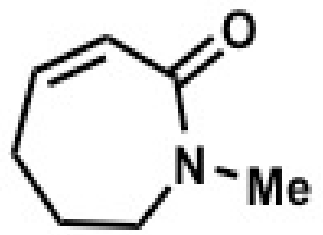

20 


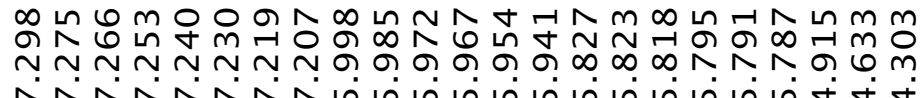

$8+1+\infty 60$

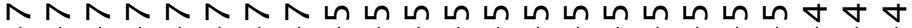
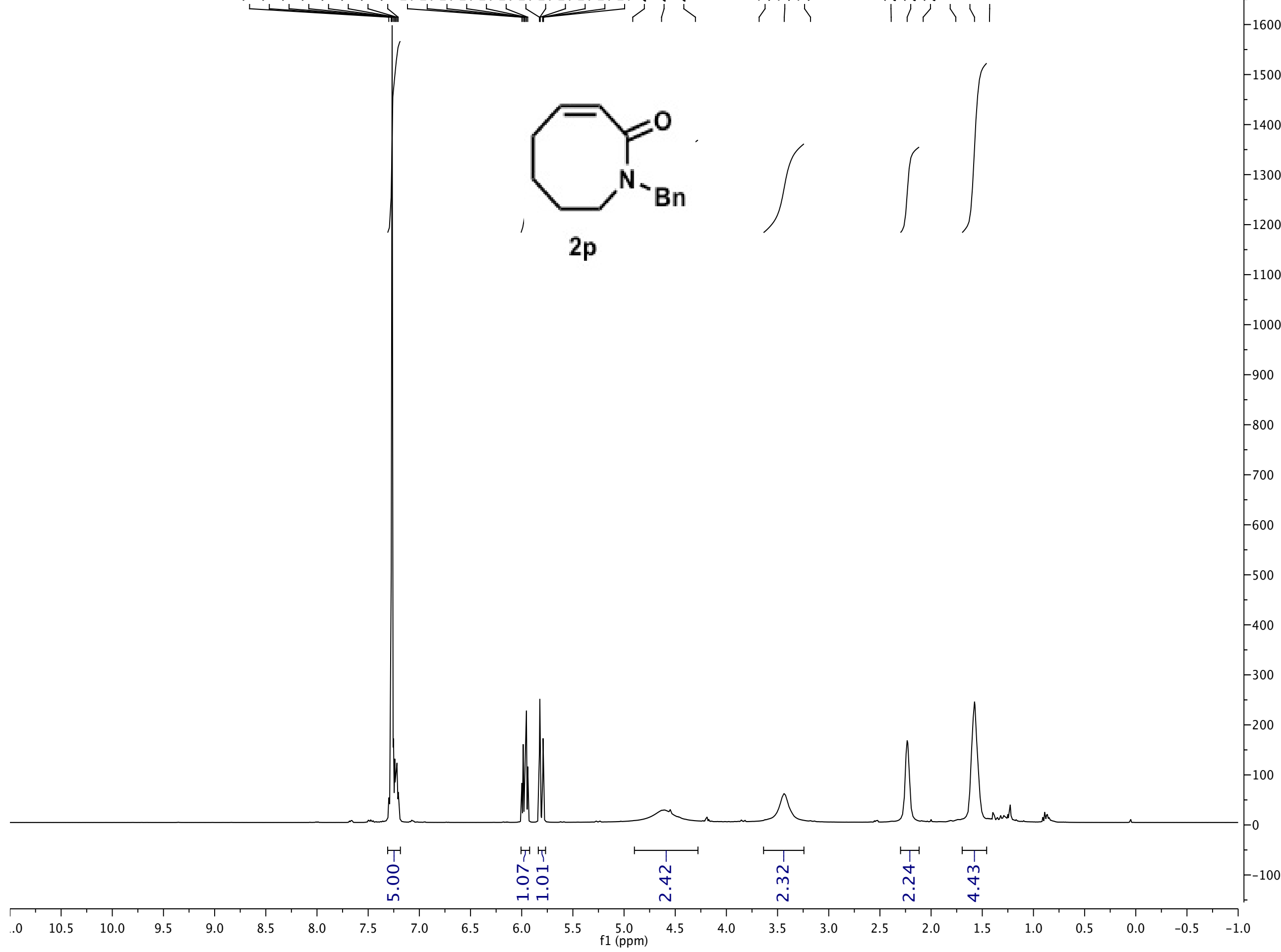

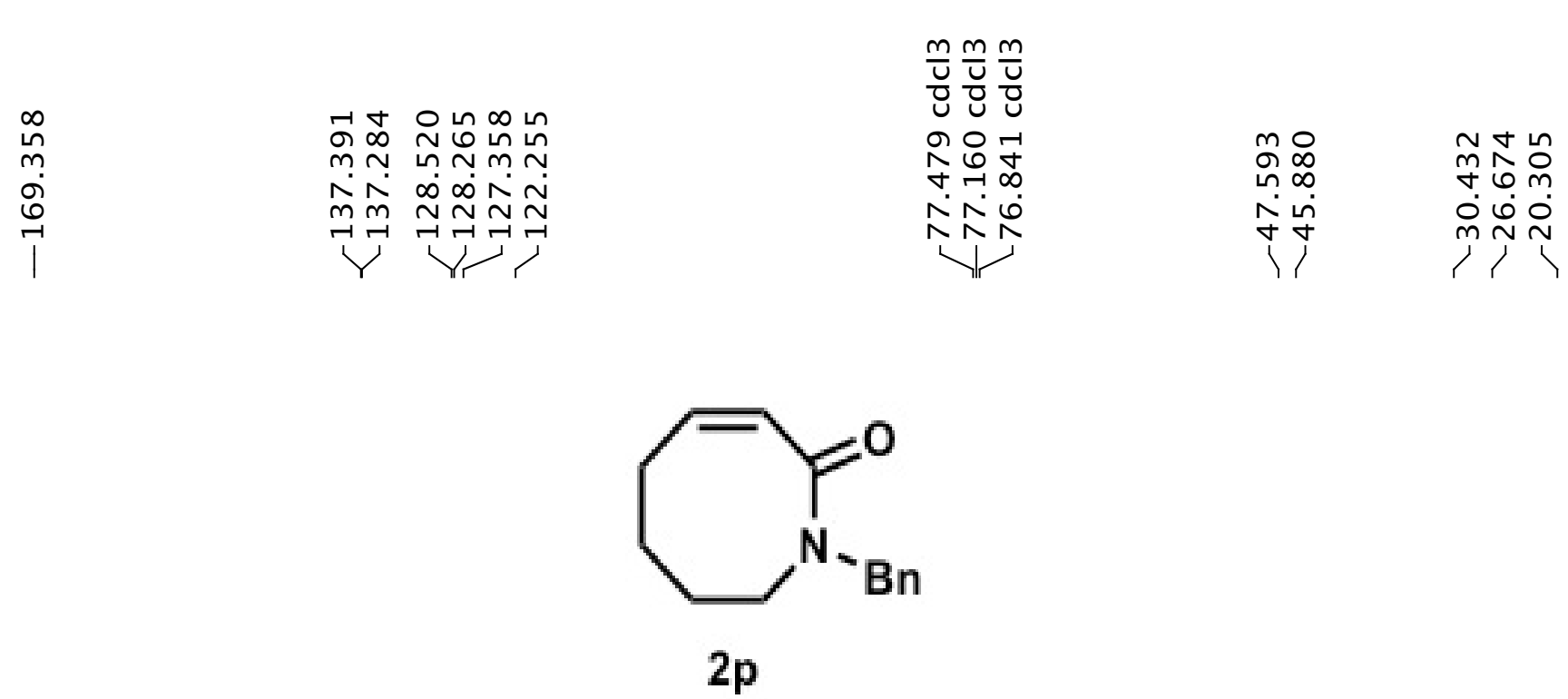
Otकmmat

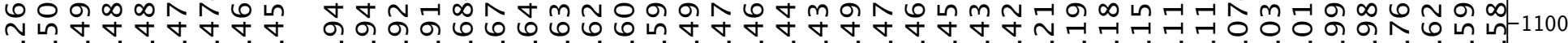


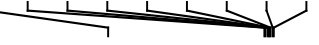

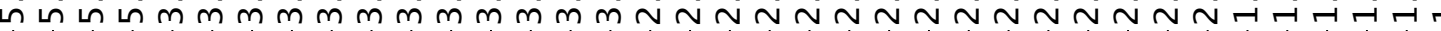
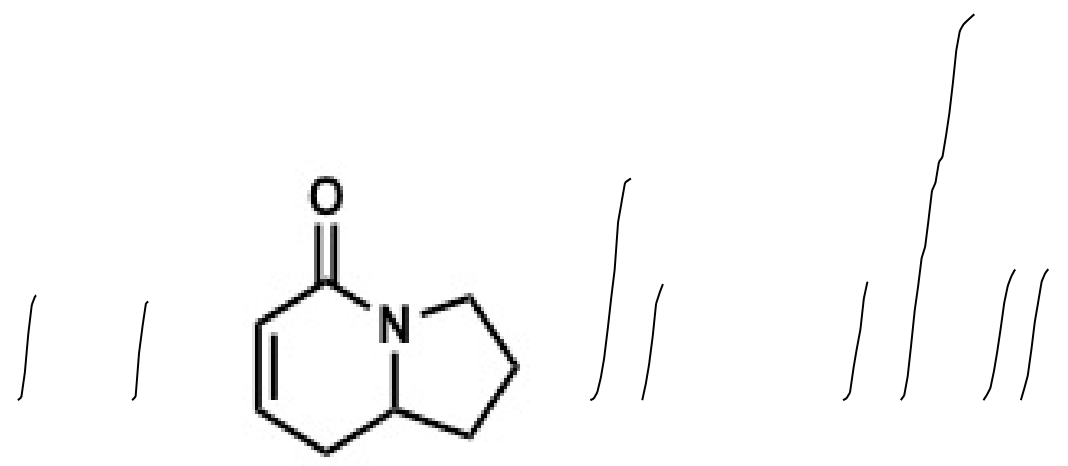

$2 q$

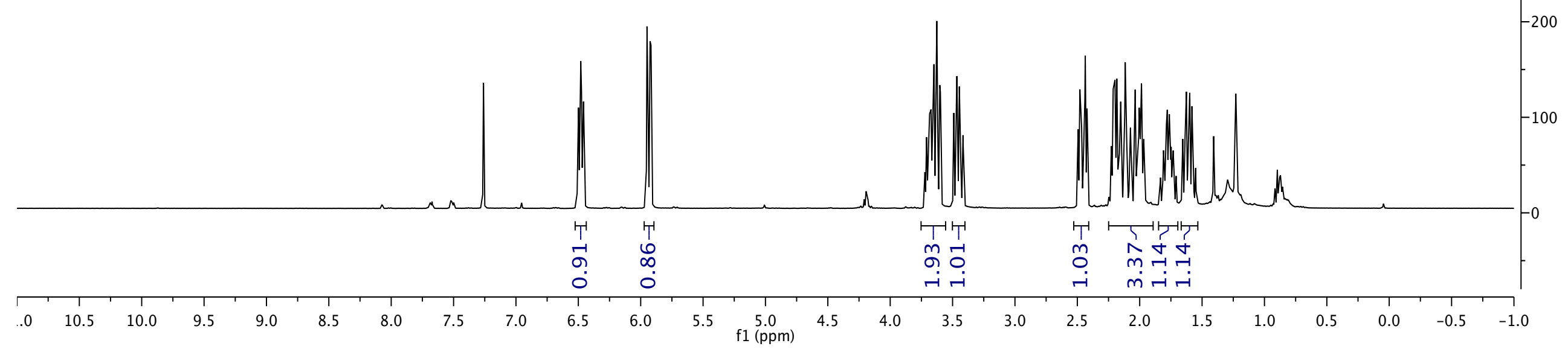




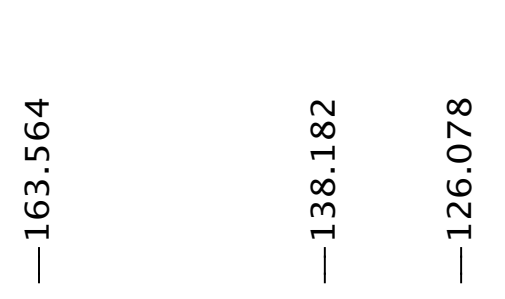

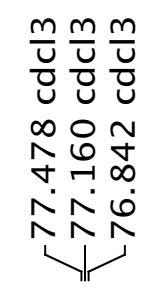

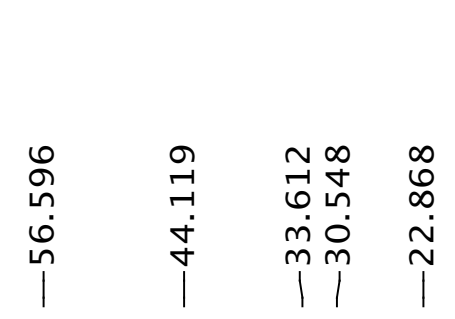<smiles>O=C1C=CCC2CCCN12</smiles>

$2 q$

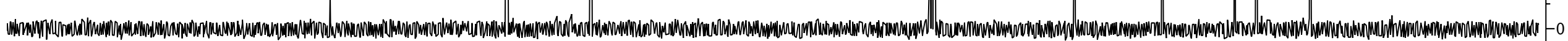

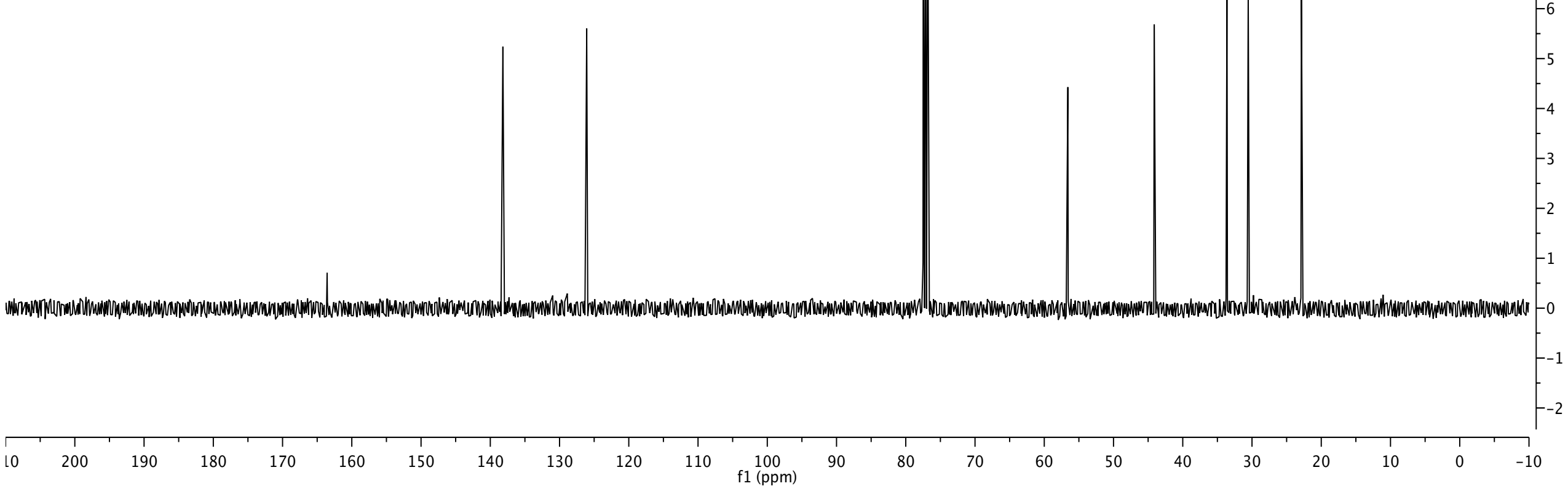




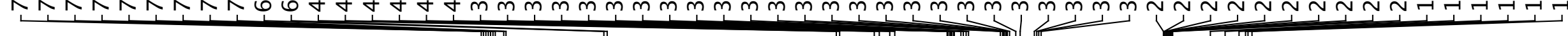
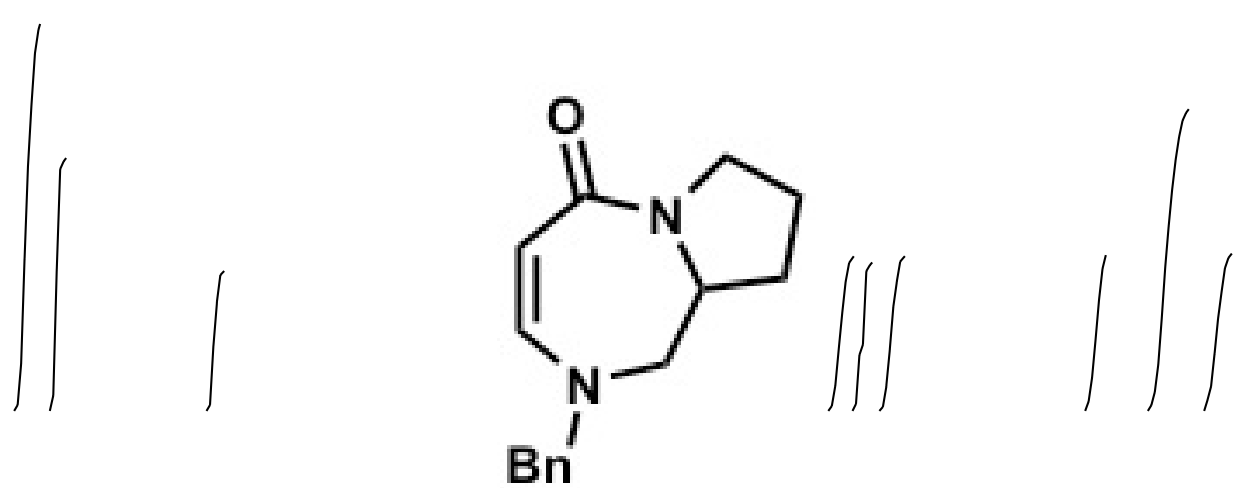

$2 r$

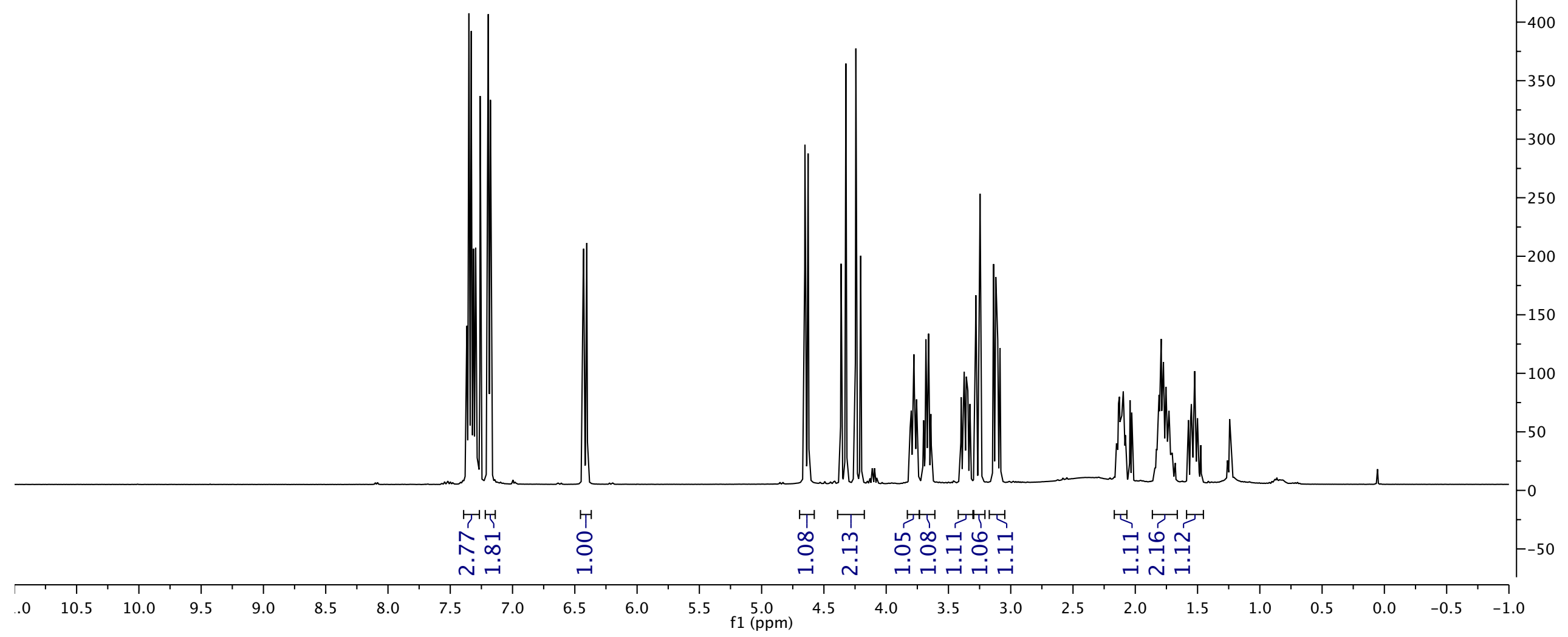




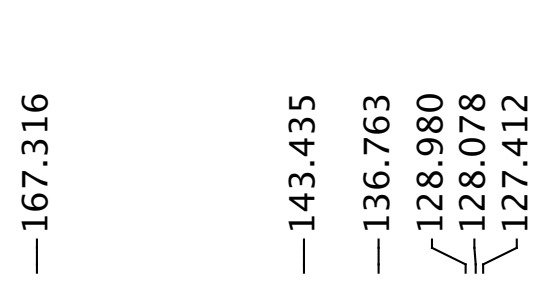

$\frac{m}{U} \frac{m}{v} \frac{m}{v}$

$\infty \quad \infty \quad \stackrel{\sim}{\sim}$

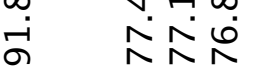

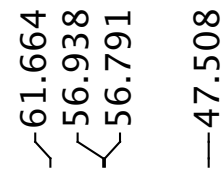

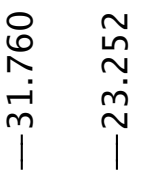<smiles>O=C1C=CN(Cc2ccccc2)CC2CCCN12</smiles>

$2 r$ 


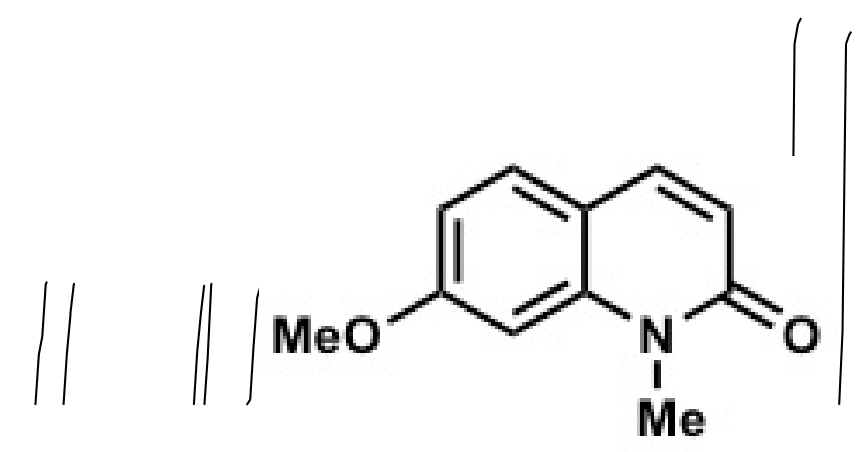

2s

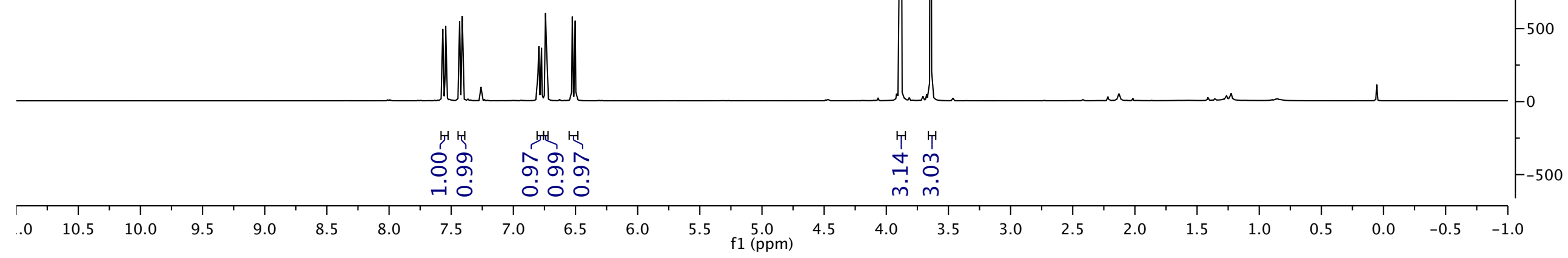



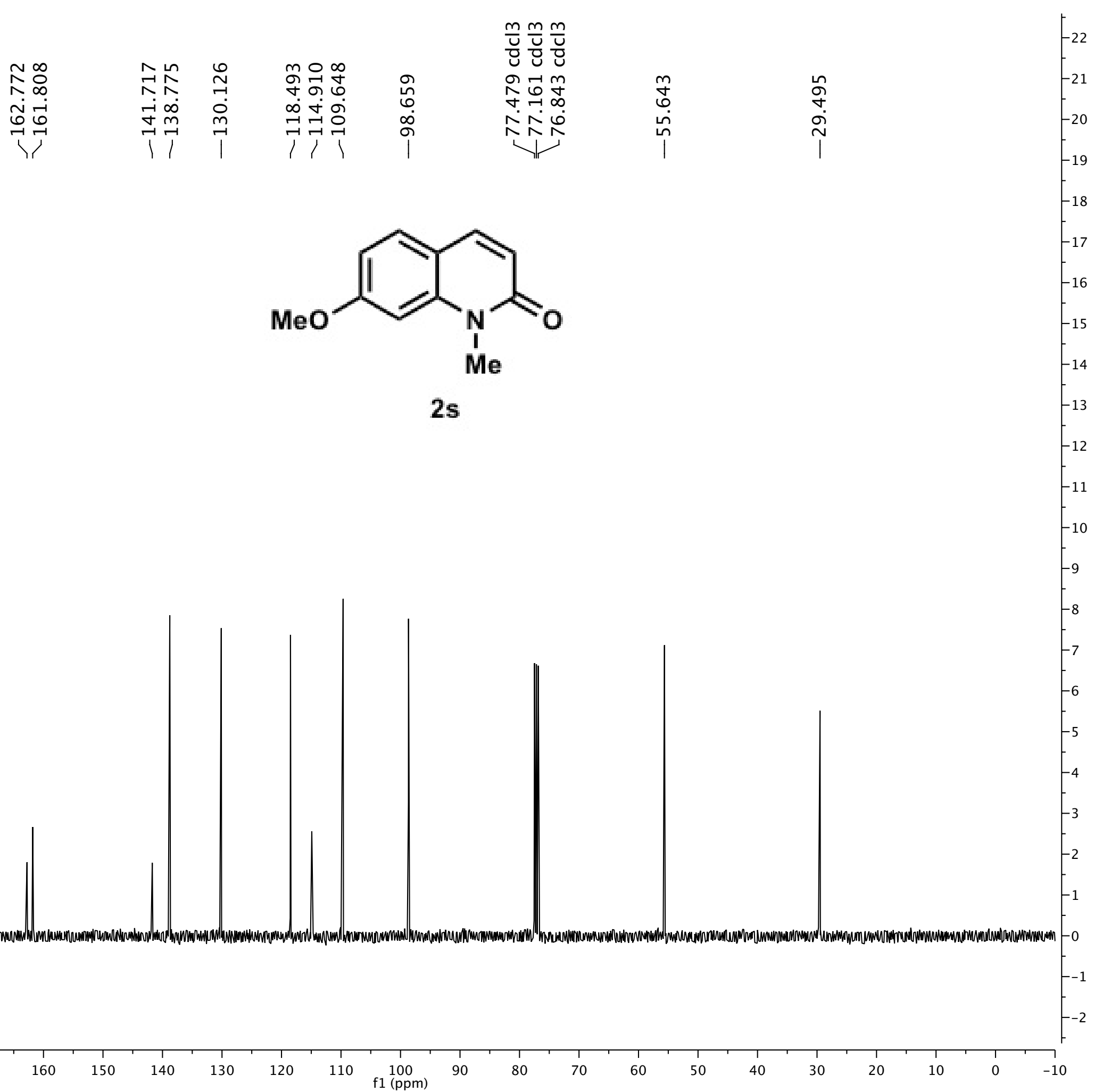


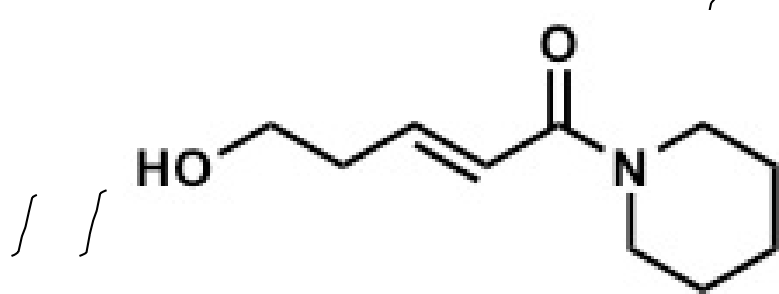

$2 t$
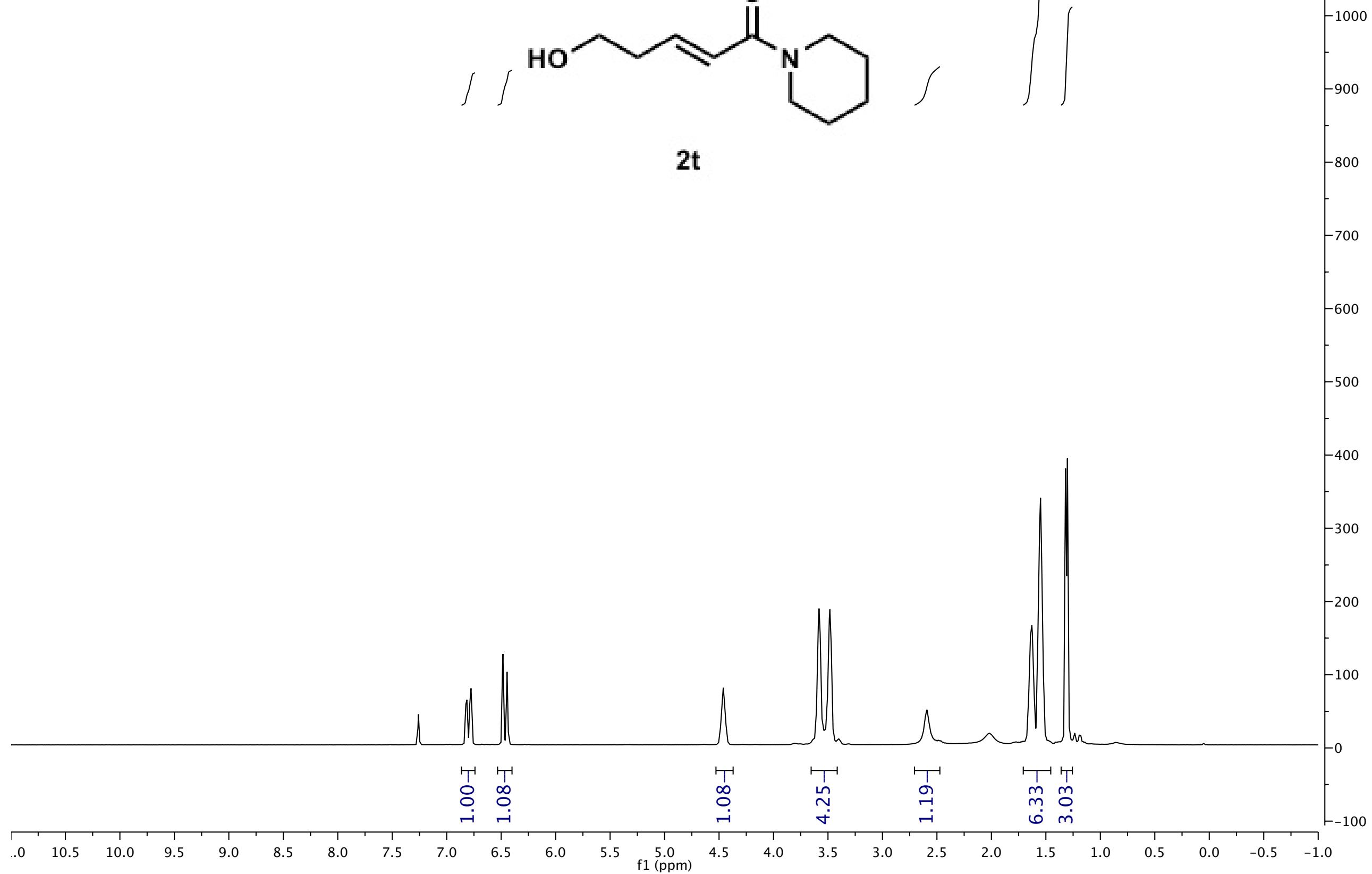


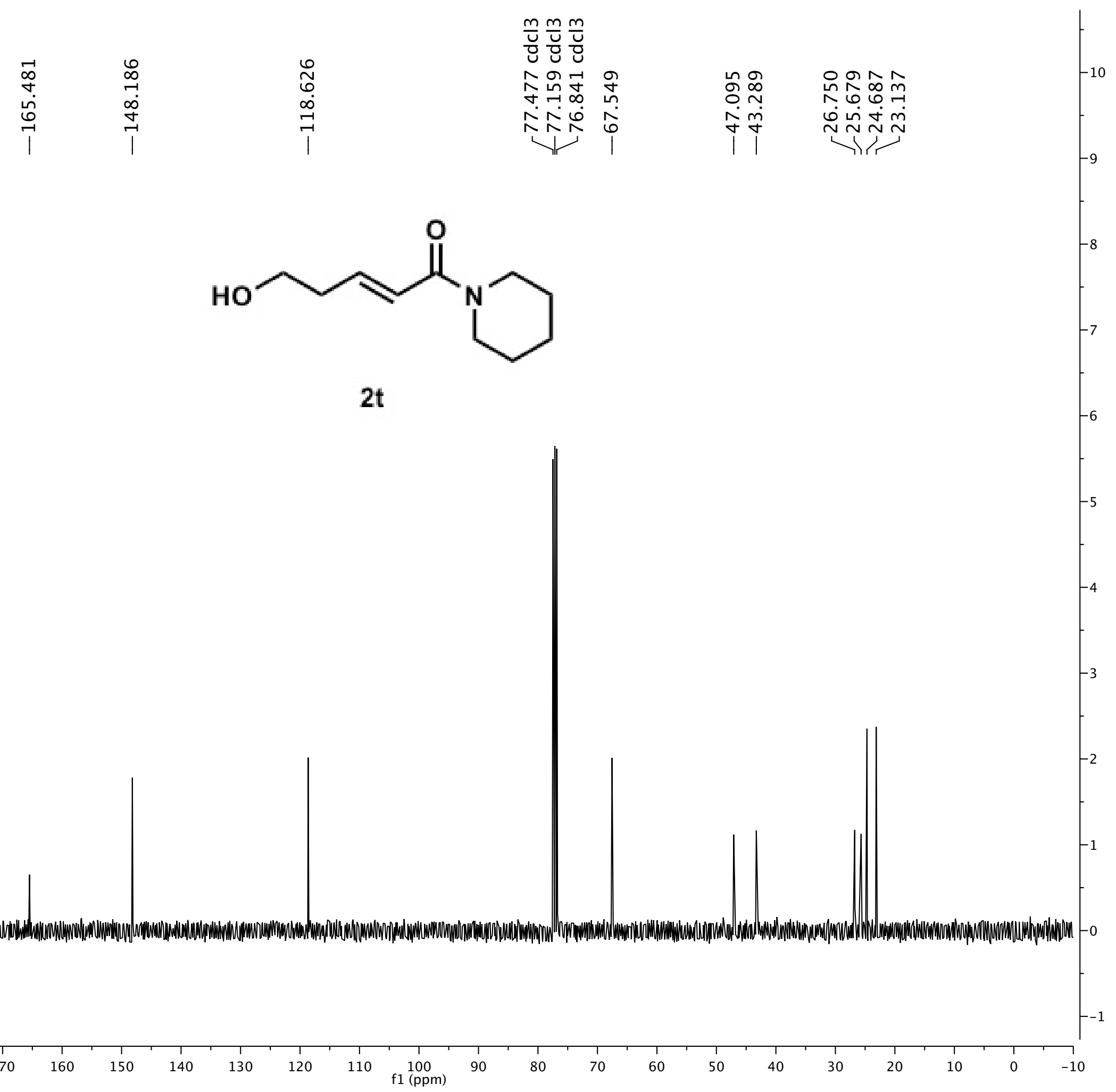



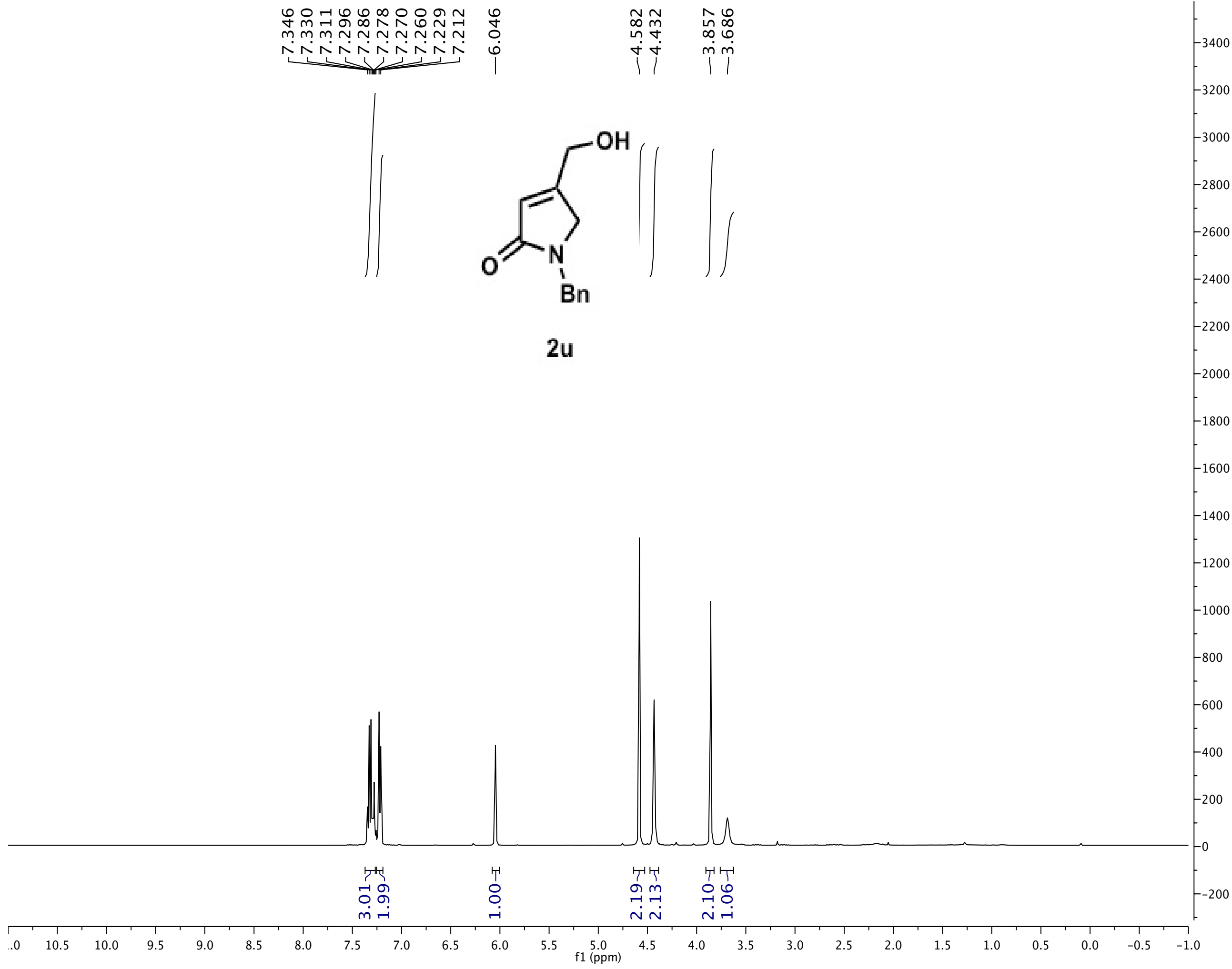


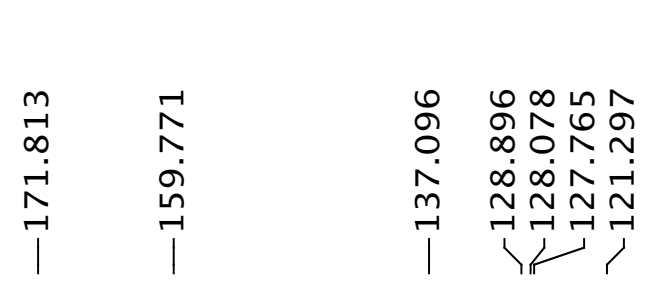

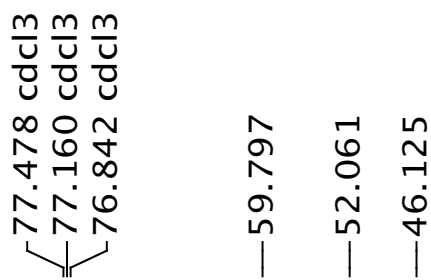

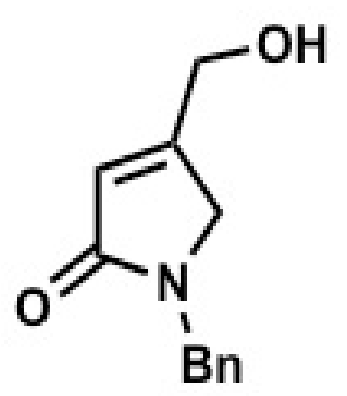

$2 \mathrm{u}$

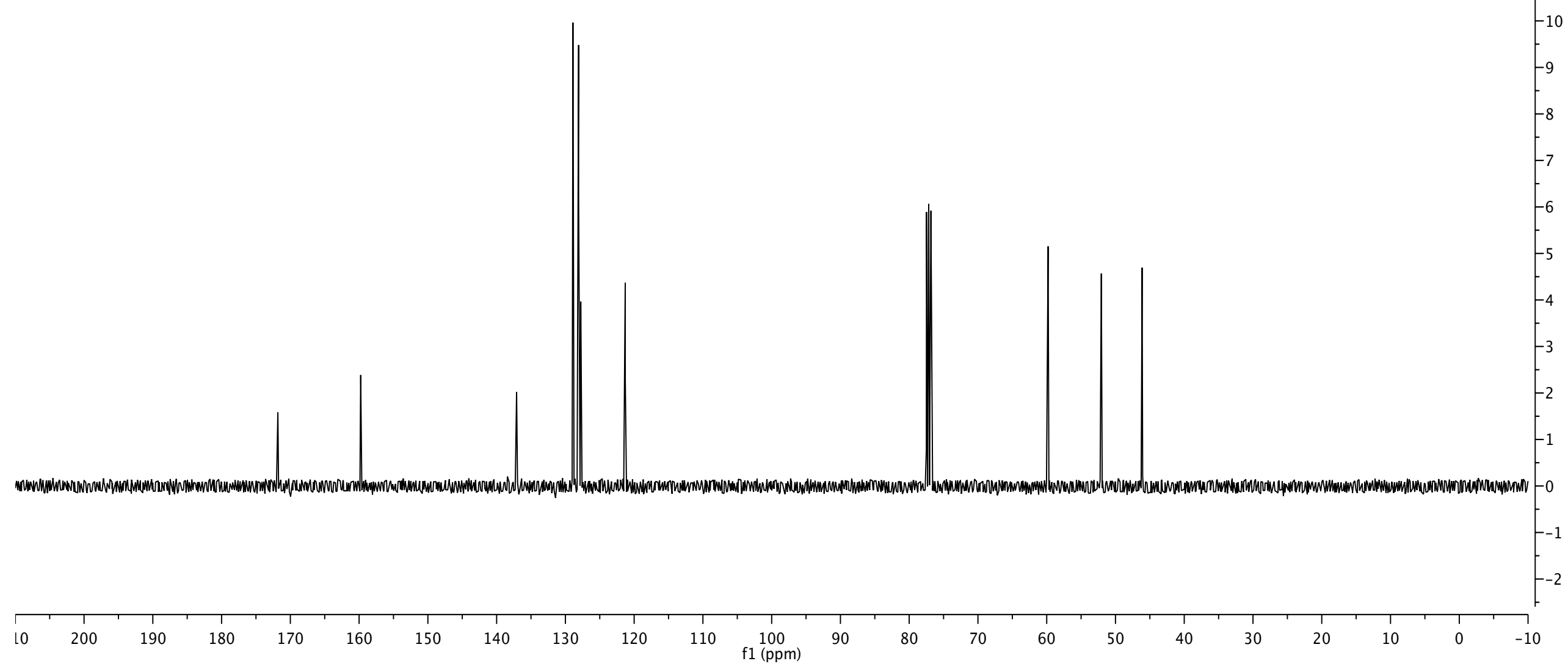



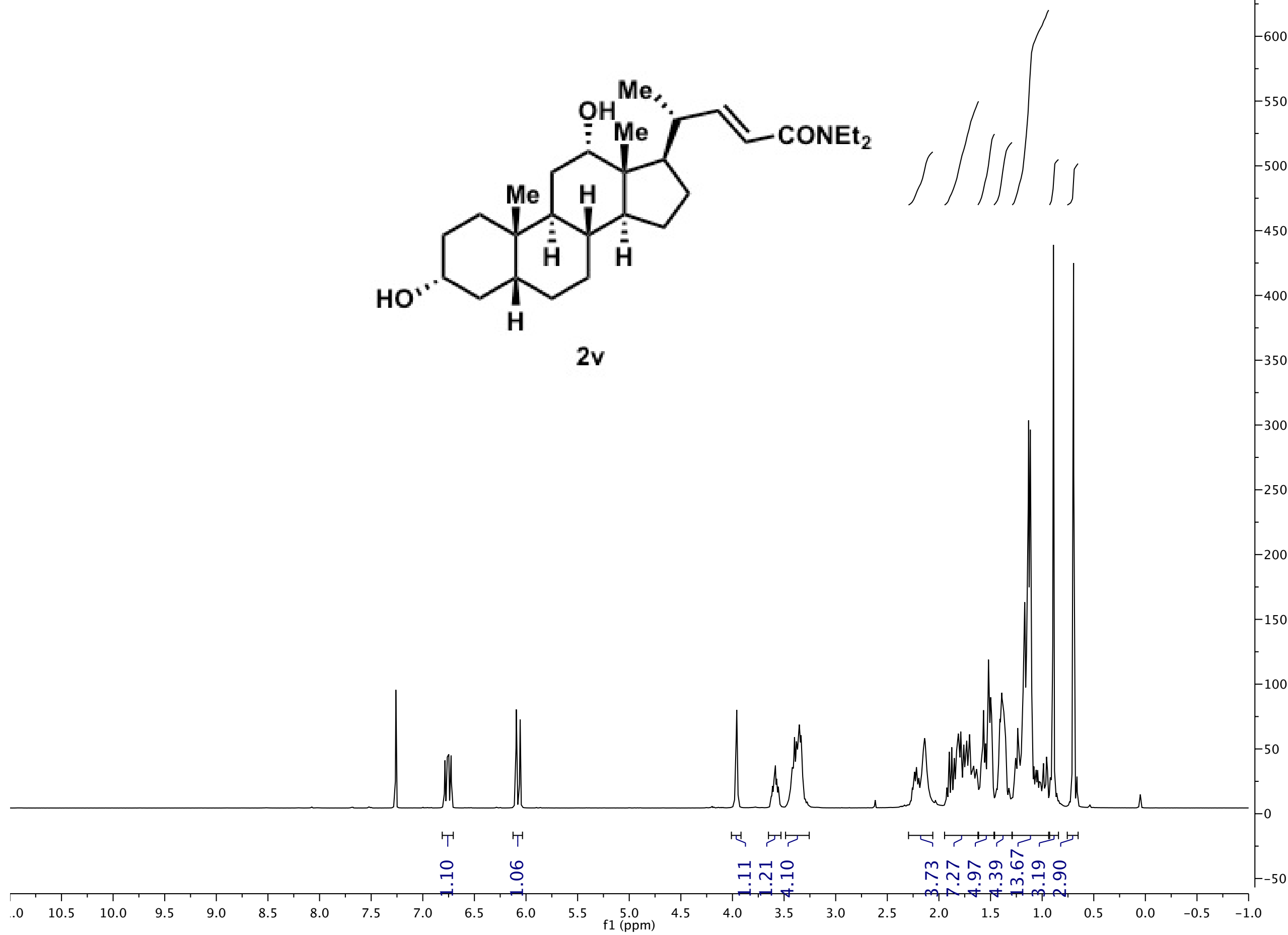


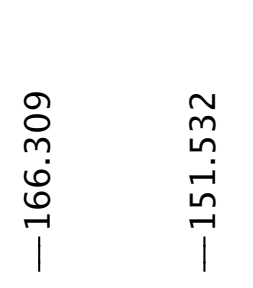
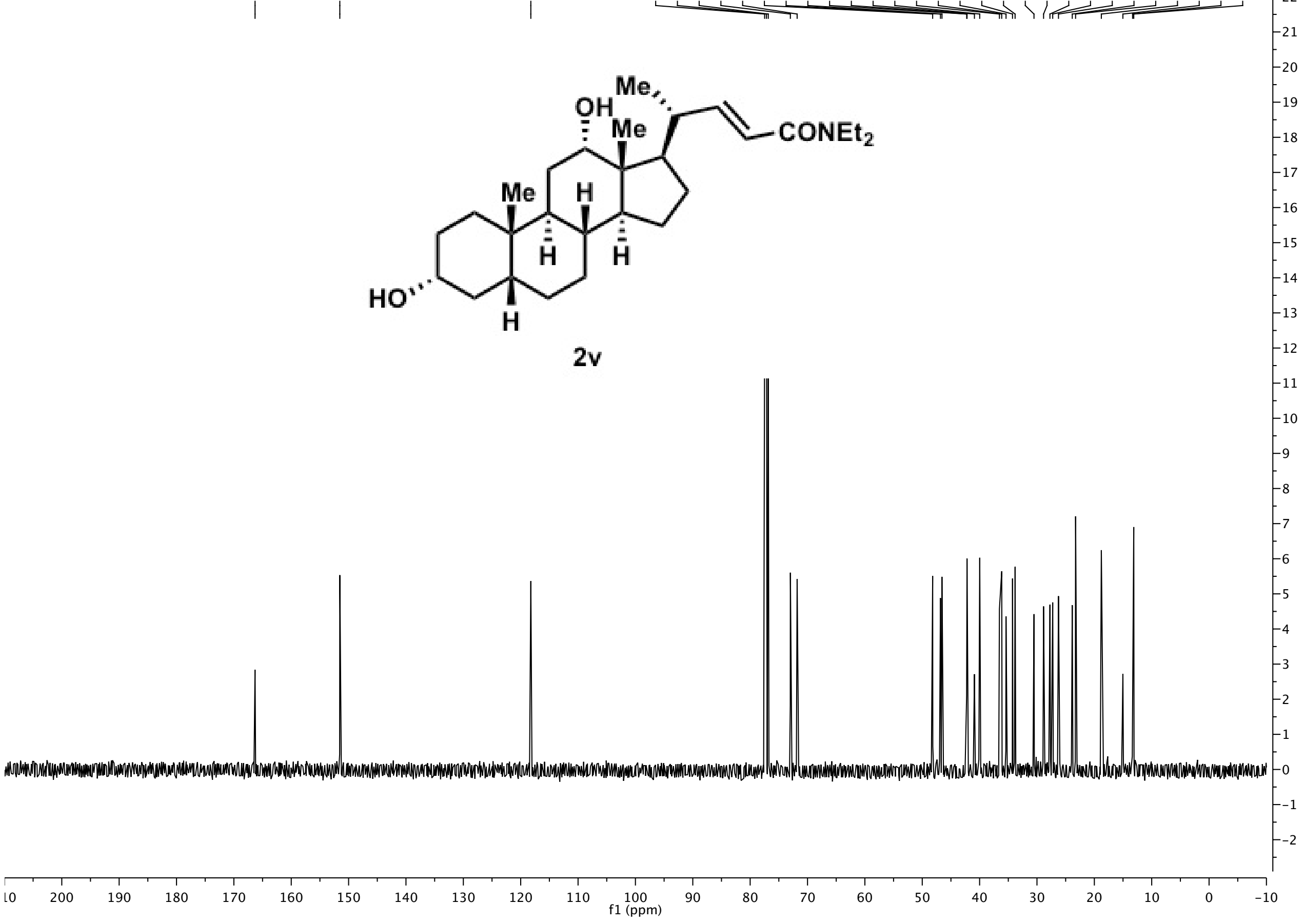


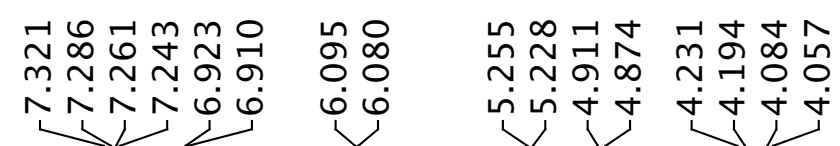

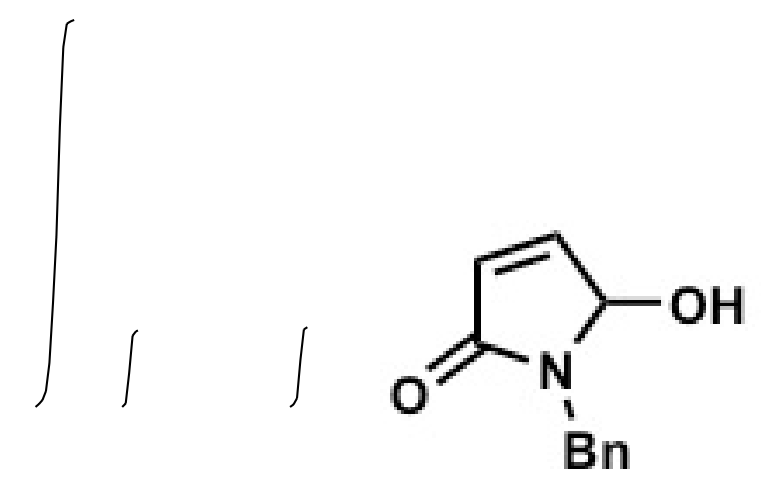

2w

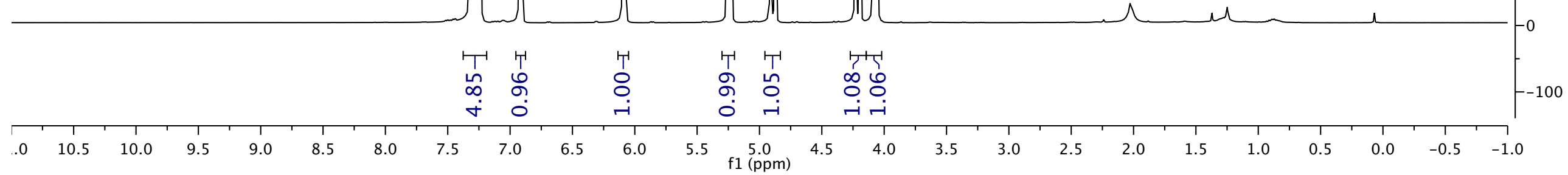



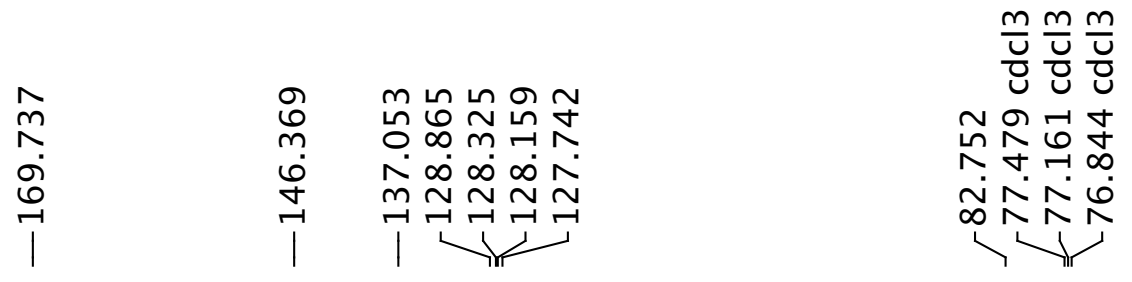<smiles>O=C1C=CC(O)N1C(=O)c1ccccc1</smiles>

Bn

2w

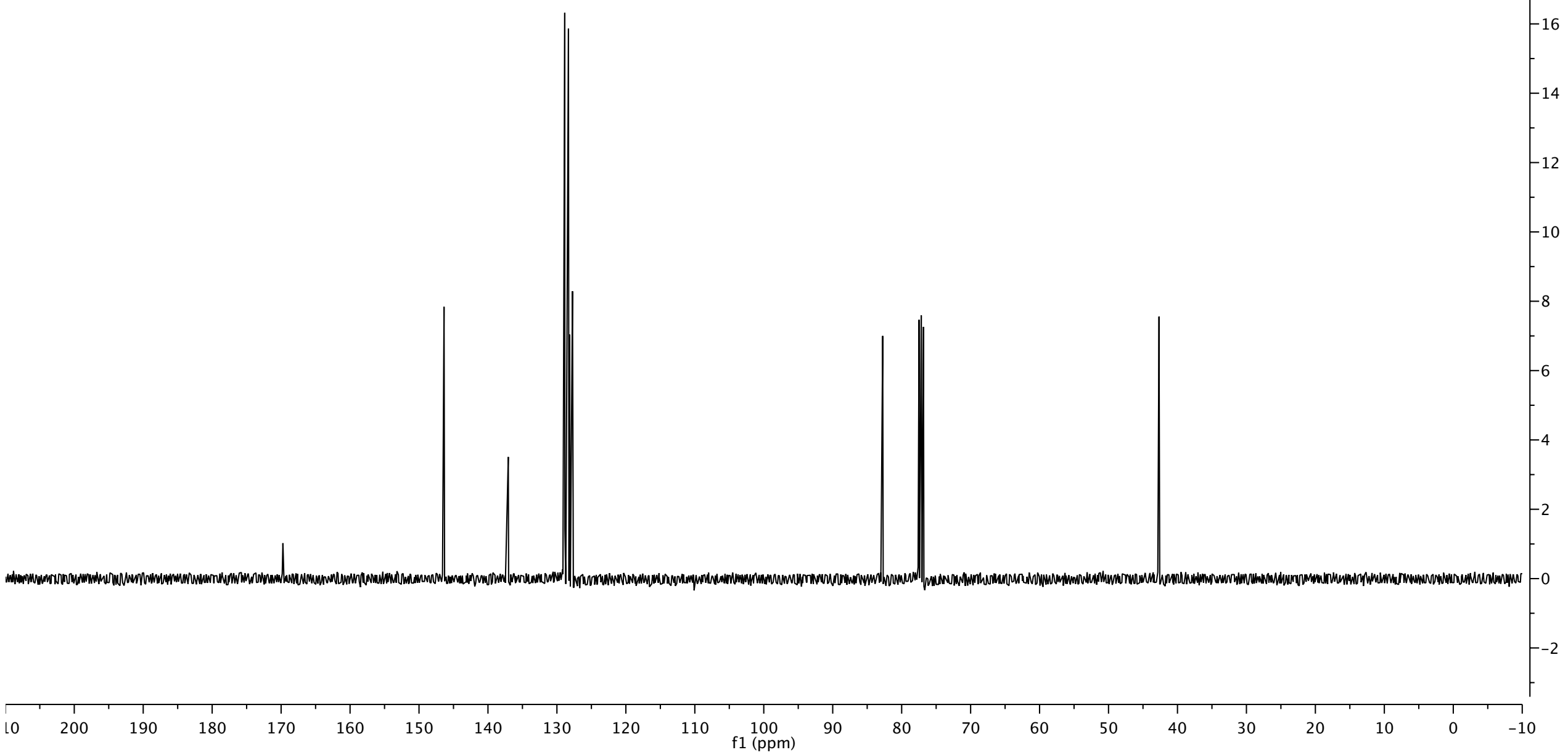



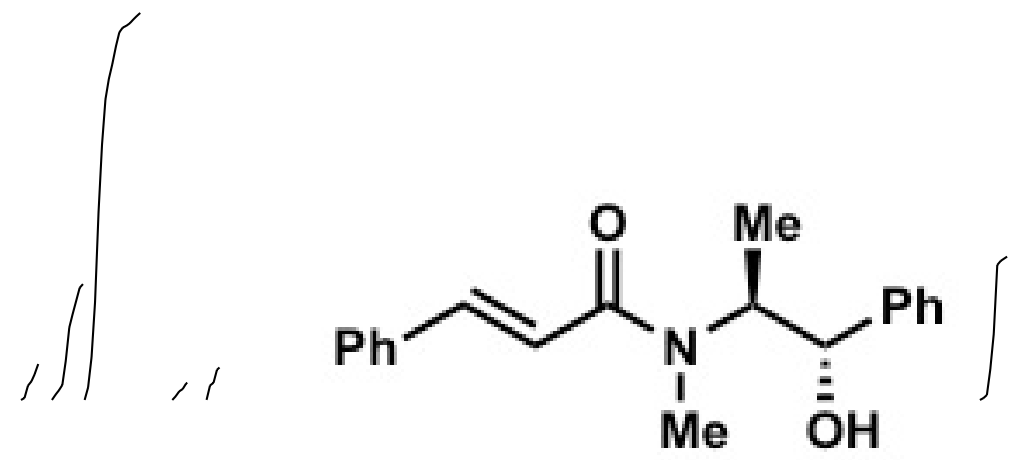

$2 x$ 
<smiles>C[C@H]([C@H](O)c1ccccc1)N(C)C(=O)/C=C/c1ccccc1</smiles>

$2 x$ 


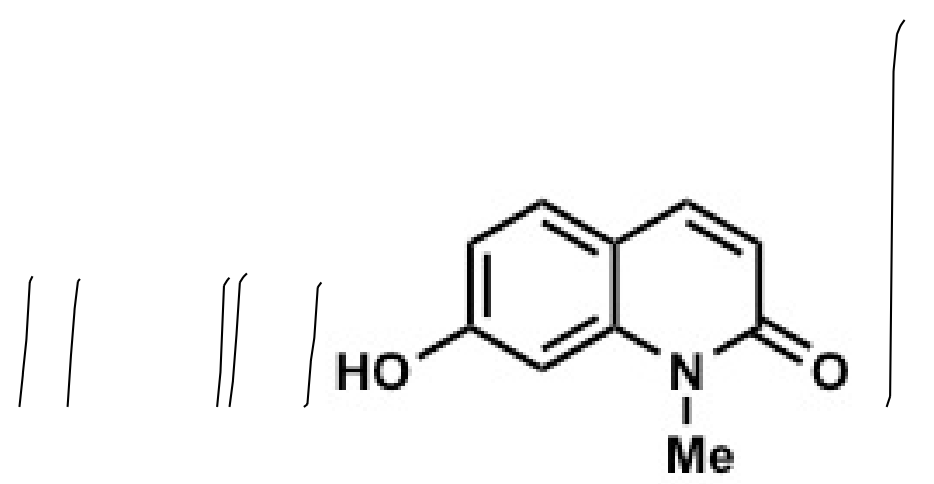

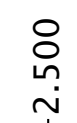

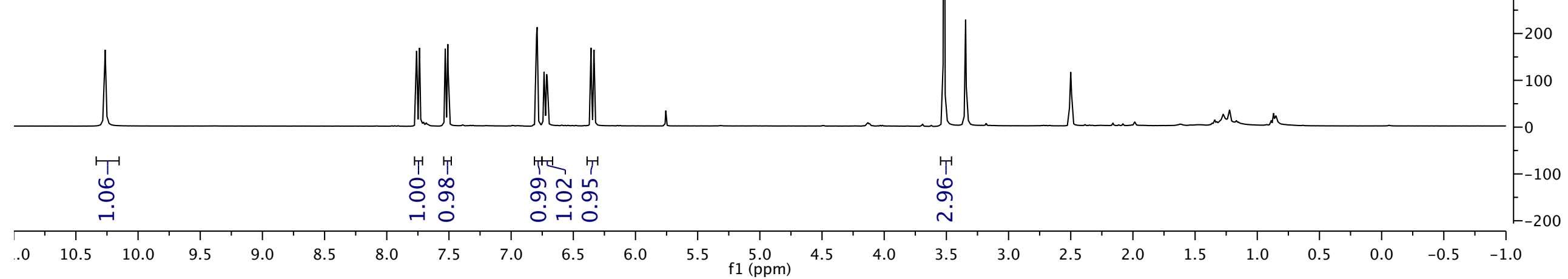




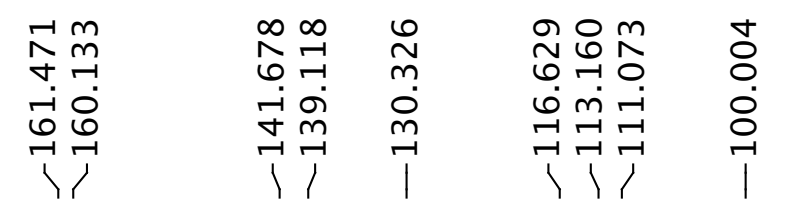<smiles>Cn1c(=O)ccc2ccc(O)cc21</smiles>

$2 y$

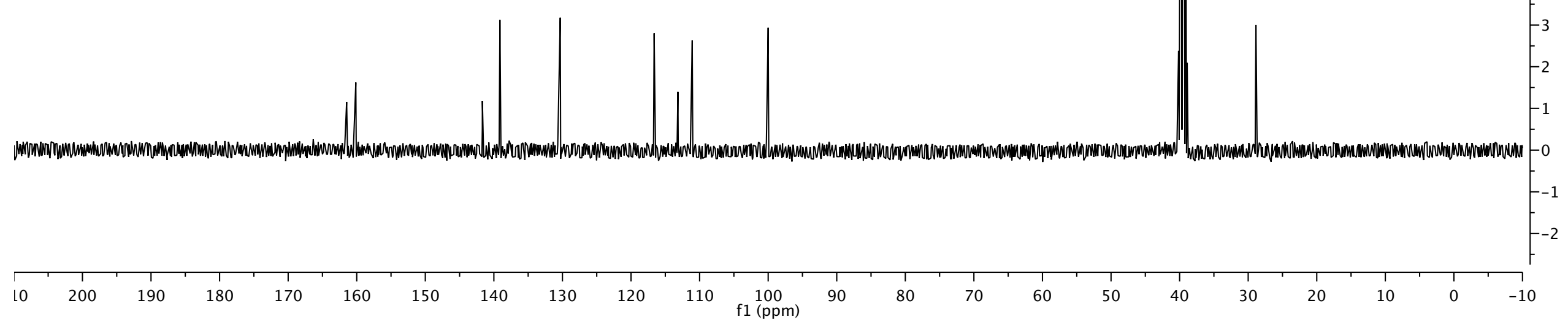




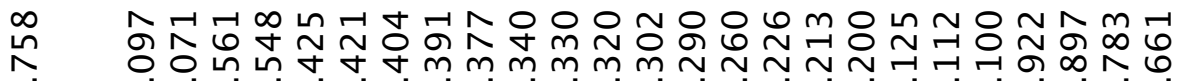

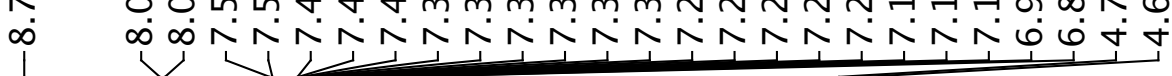
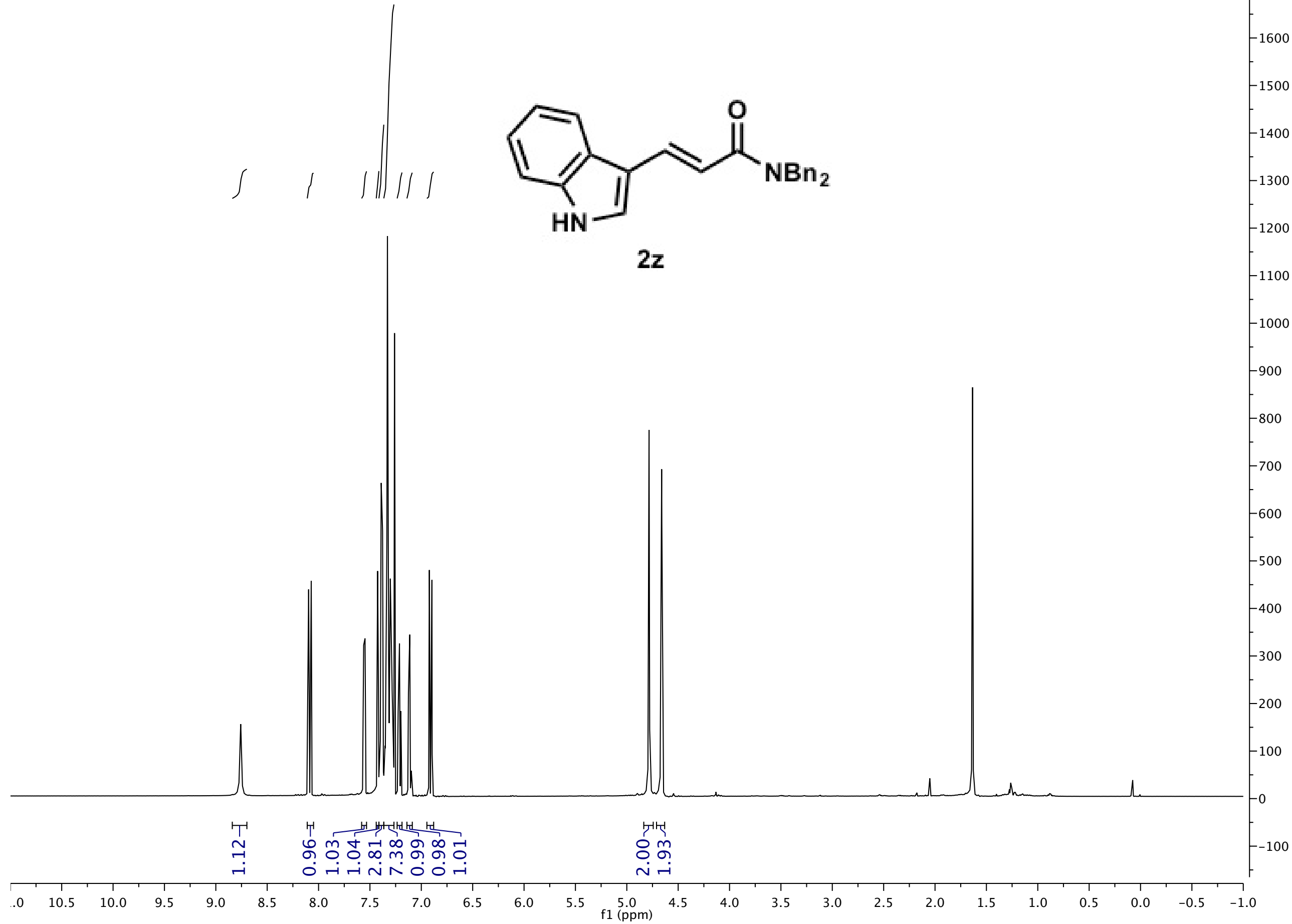


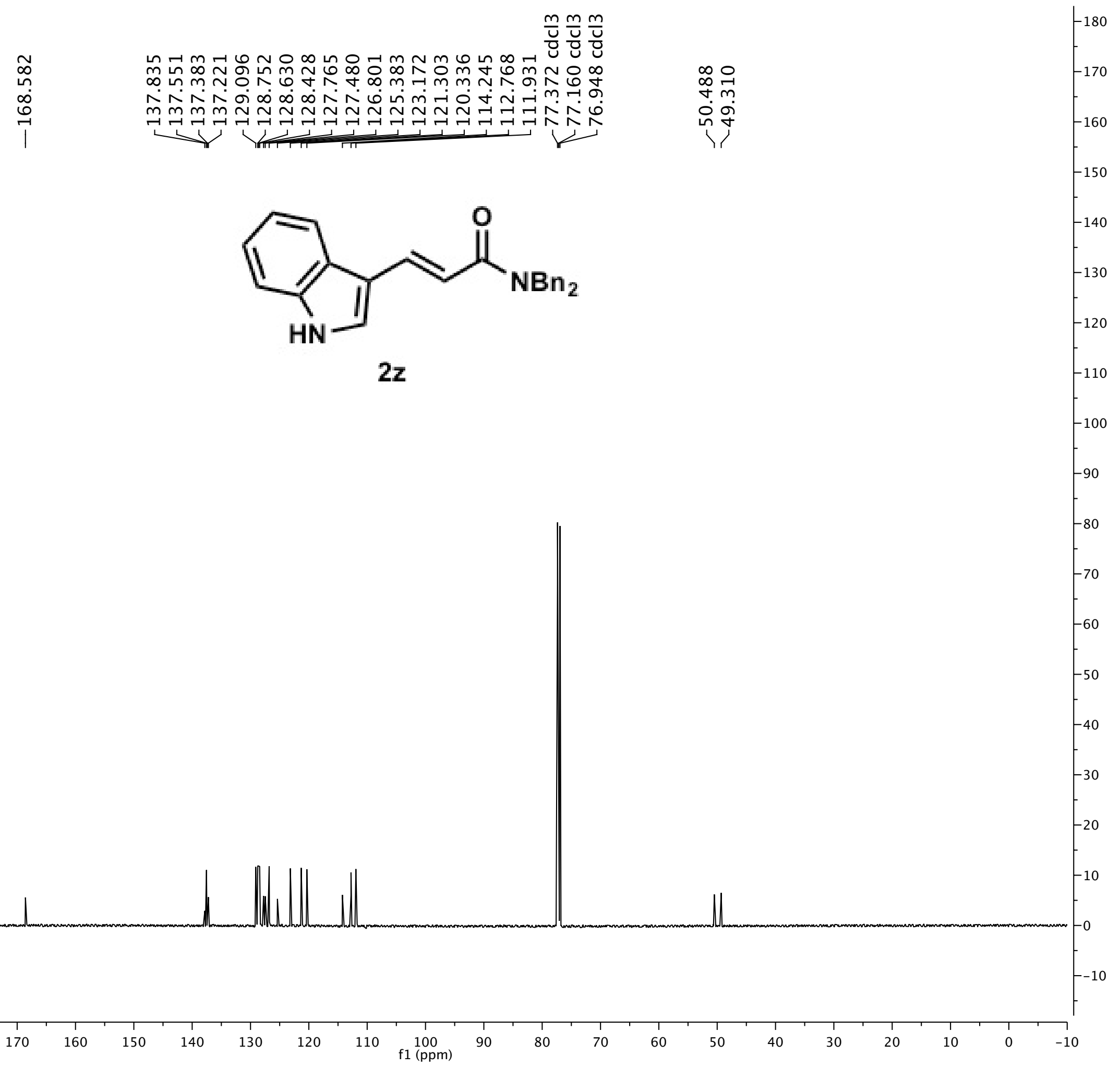




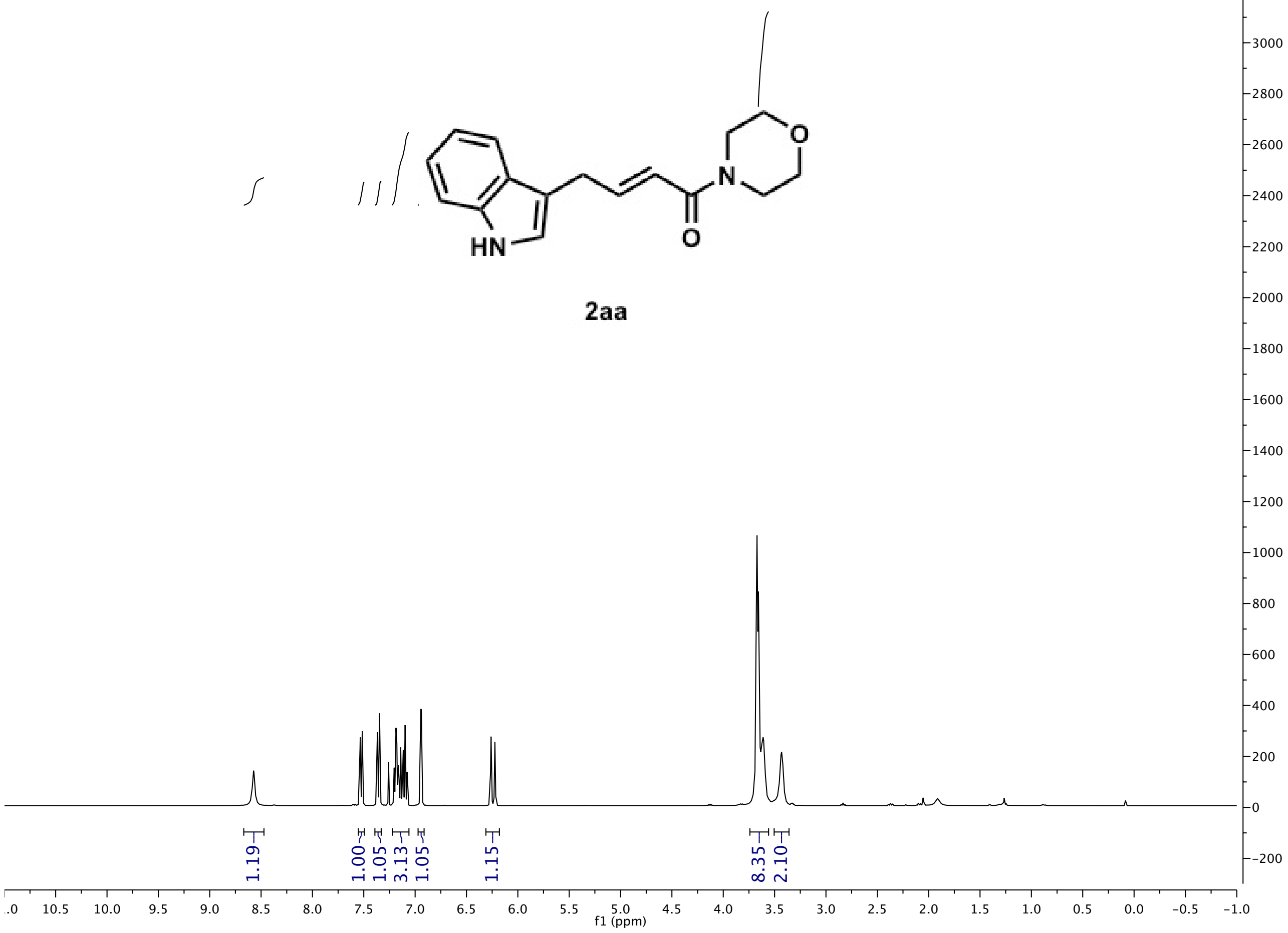




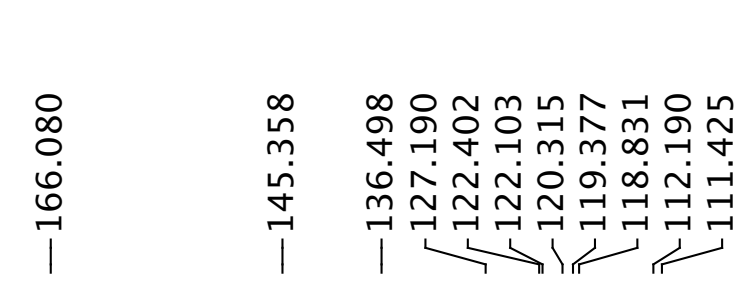

$\frac{m}{U} \frac{m}{v} \frac{m}{v}$

숭교

$\hat{N} \wedge \dot{0}$

人ิ

노

$\rightarrow m$

I I

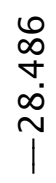<smiles>O=C(/C=C/Cc1c[nH]c2ccccc12)N1CCOCC1</smiles>

2aa

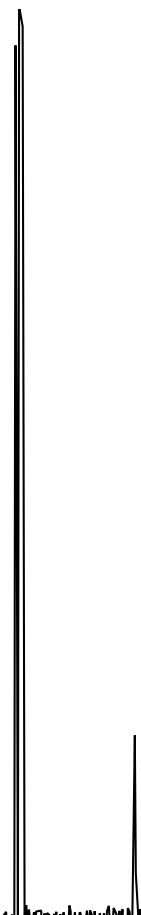




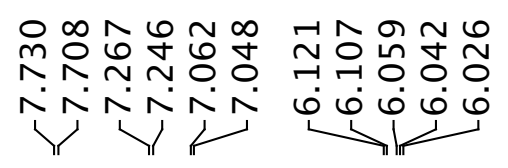

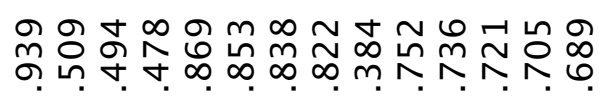

نं ${ }^{2}$ i

NヘNÑÑ

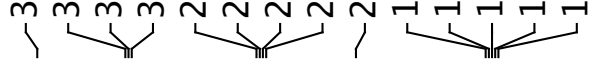
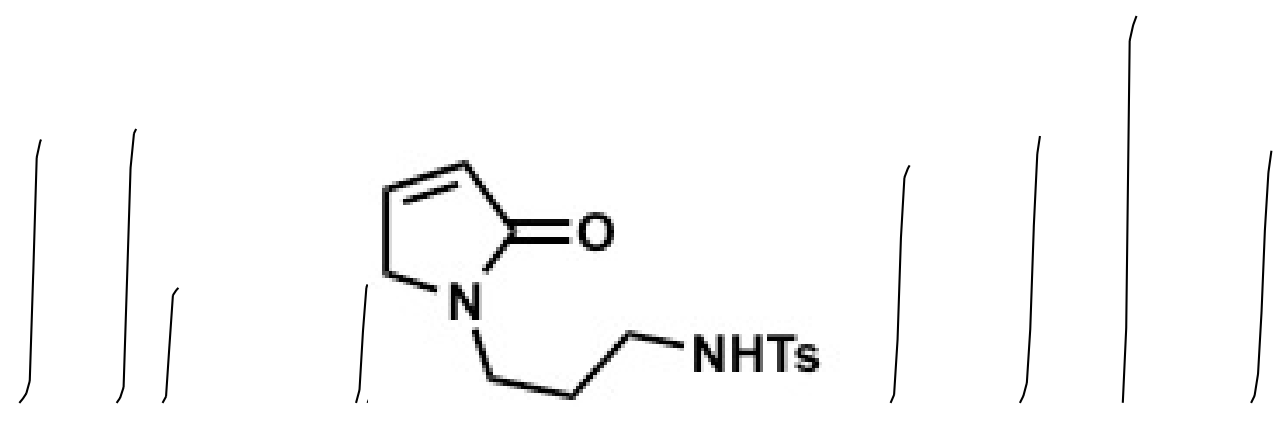

$2 a b$

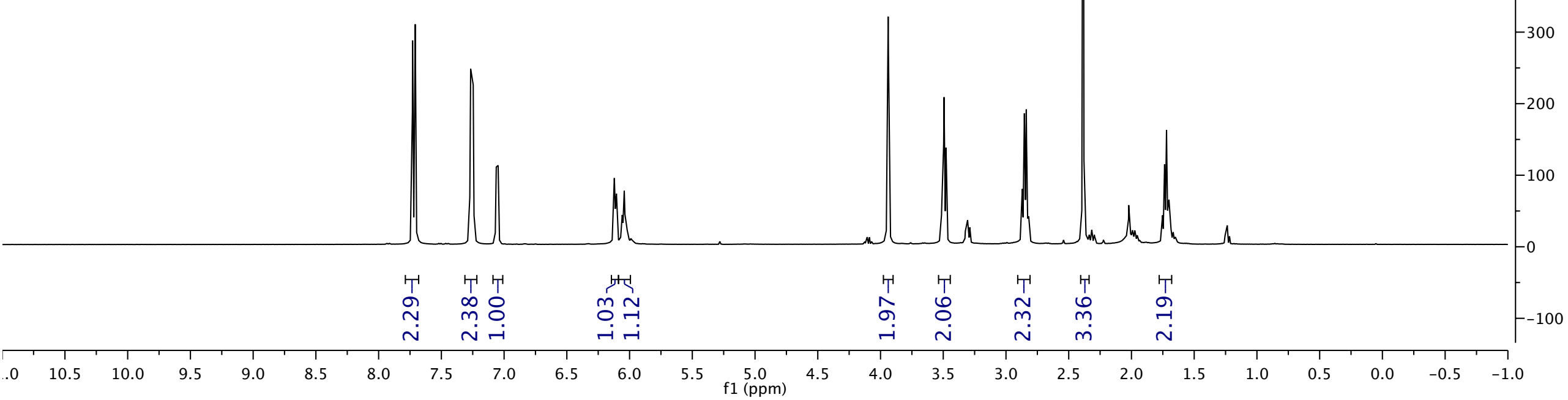




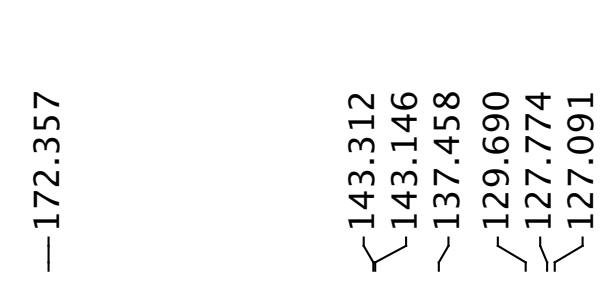

$\frac{m}{U} \frac{m}{v} \frac{m}{v}$

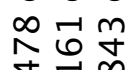

กํำ

舟

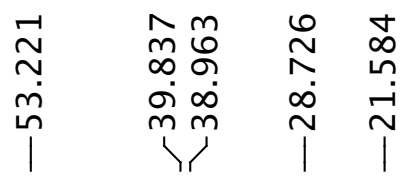

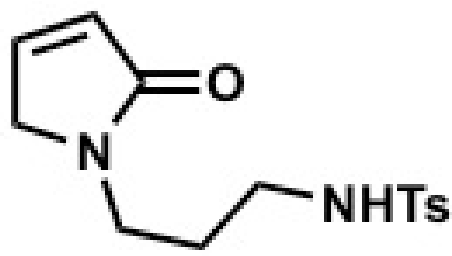

$2 a b$

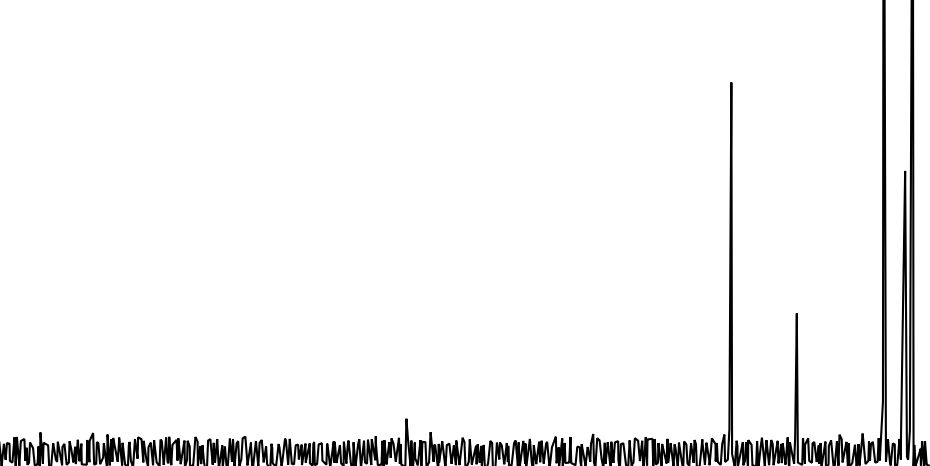




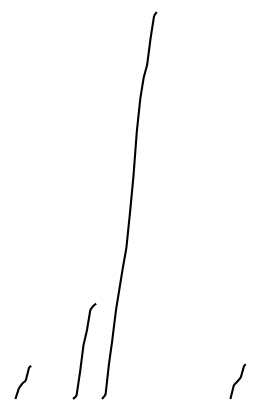<smiles>CCCCC(=O)/C=C/c1ccc(Nc2ccccc2)cc1</smiles>

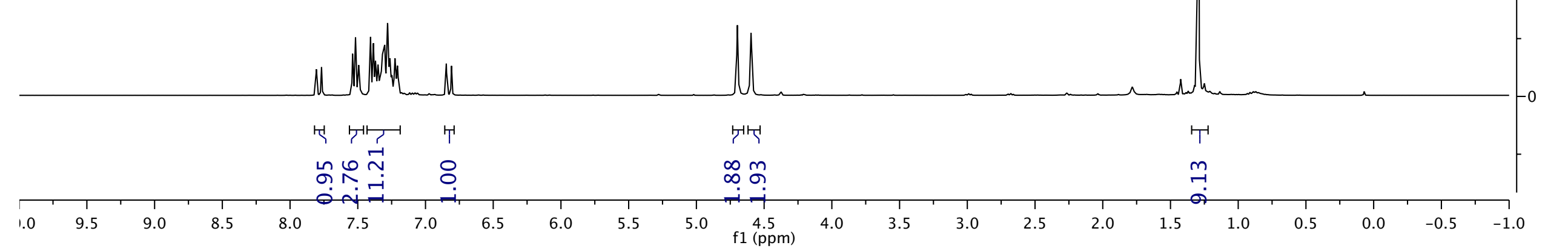


<smiles>CCCCC(=O)C=Cc1ccc(Nc2ccccc2)cc1</smiles>

2ac 

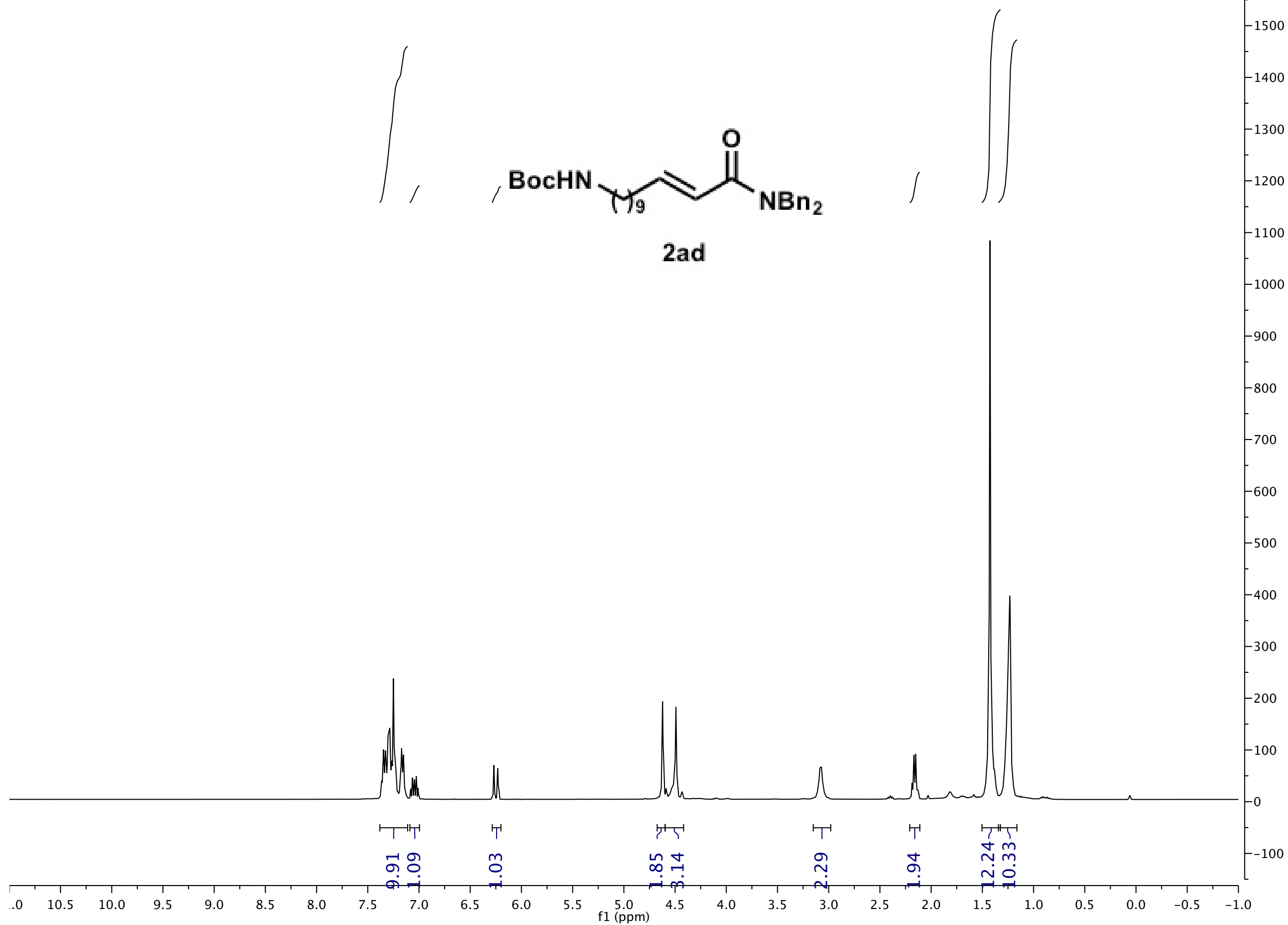

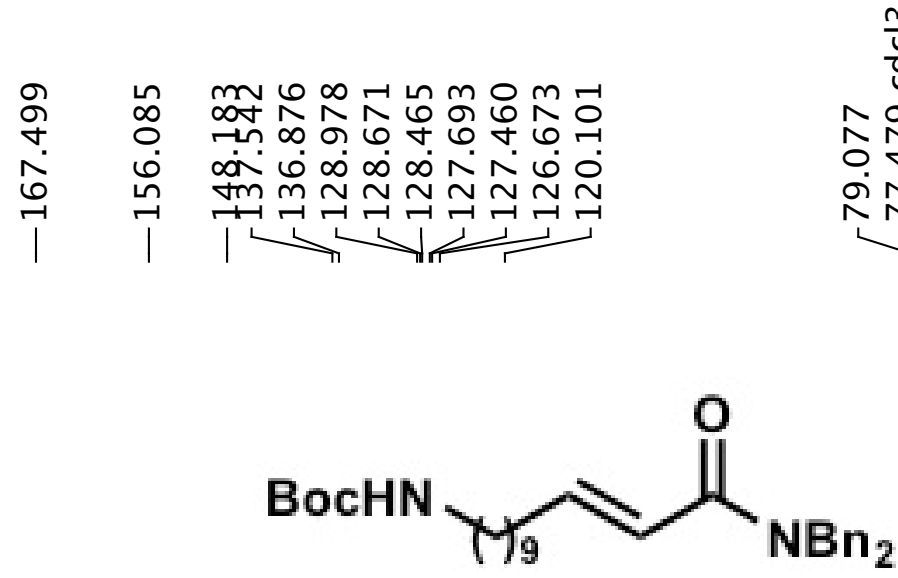

2ad
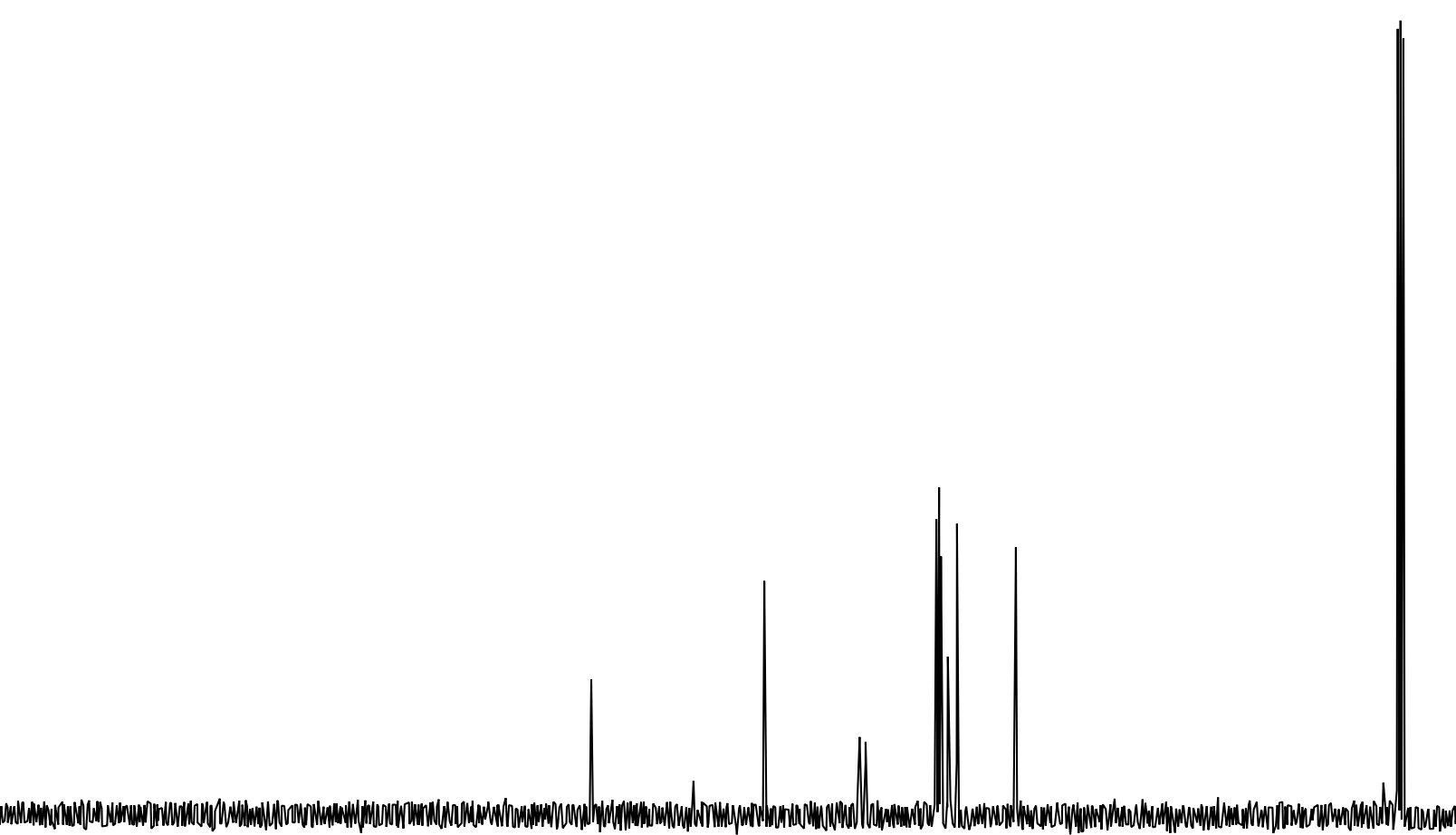


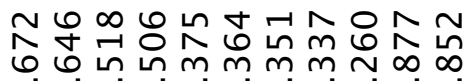

ט

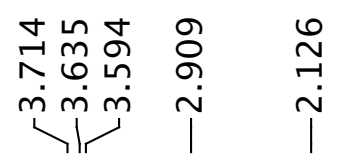

$-1200$
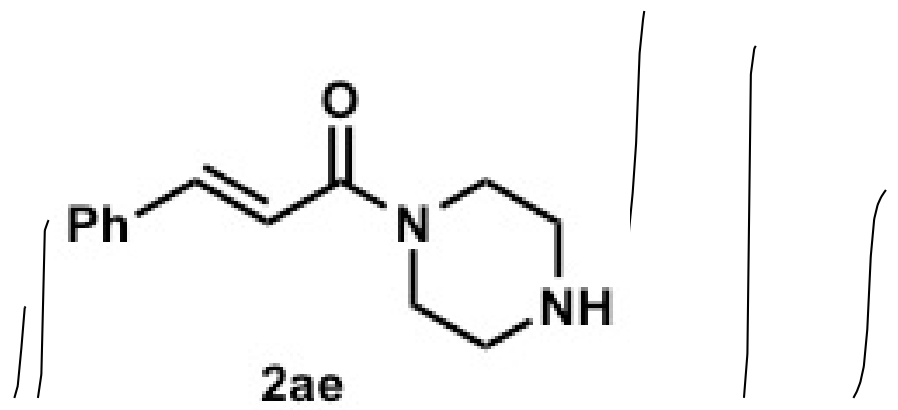

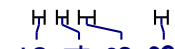

ตุ

○ं $\sim 0^{\circ}$

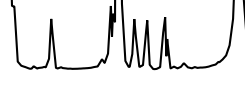




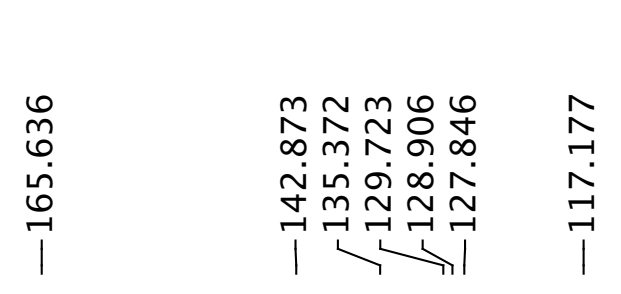

$\frac{m}{U} \frac{m}{U} \frac{m}{U}$

숭

m.

กิ์

ने 웡

于守垨学

$\checkmark$

il

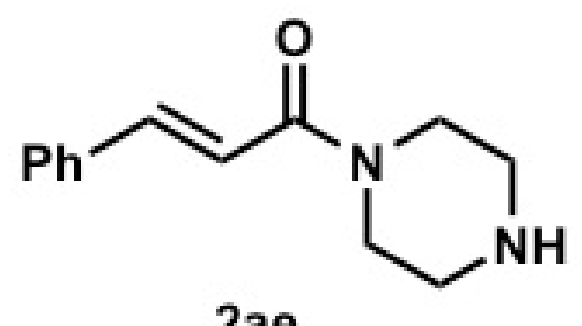

$2 a e$

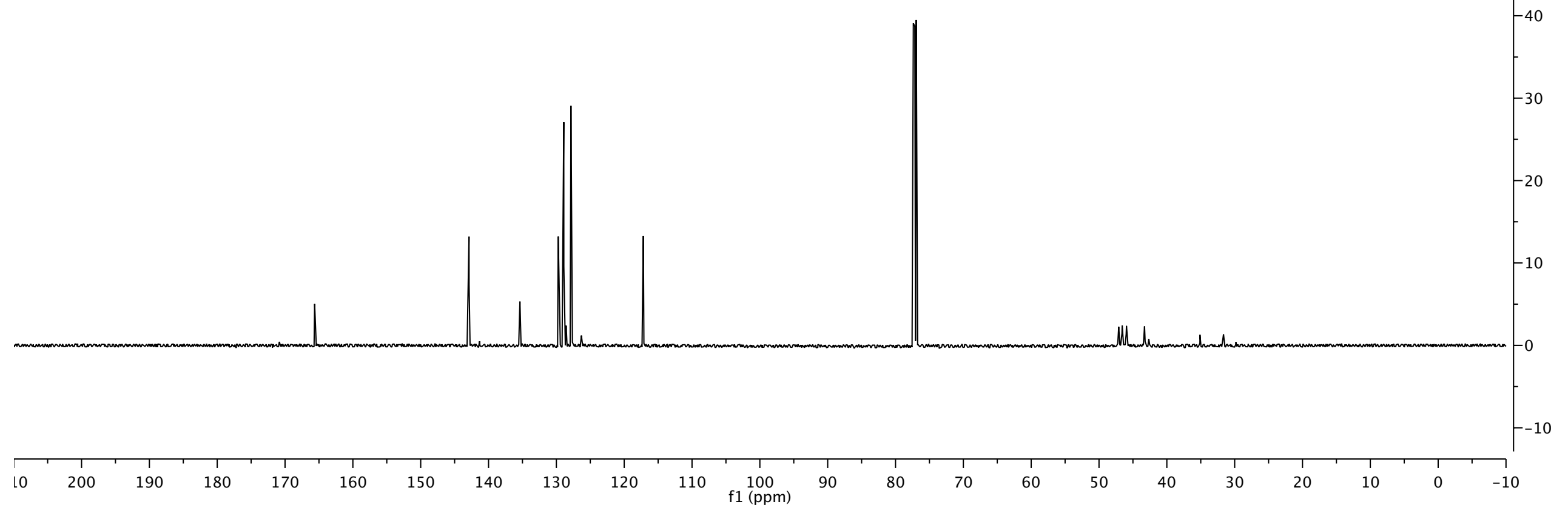


の

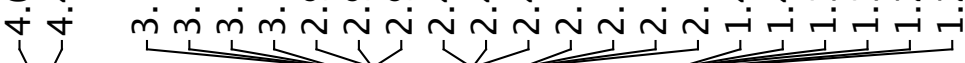

L

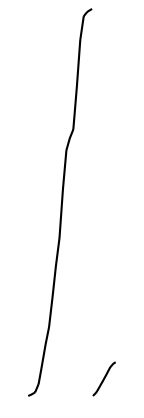<smiles>CCC(C)C(=O)/C=C/CNC(=O)CCc1ccccc1</smiles>

\section{2af}

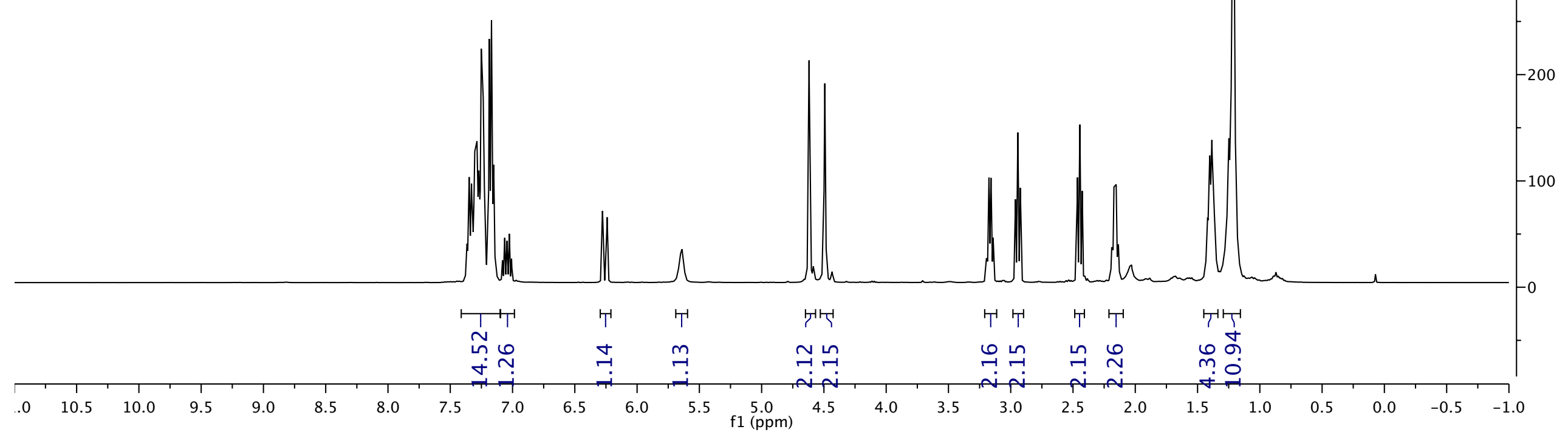


<smiles>CCCCC(=O)C=CC=CNC(=O)CCc1ccccc1</smiles>

\section{2af}




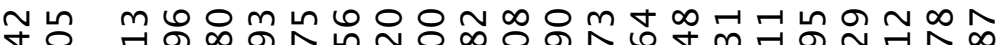

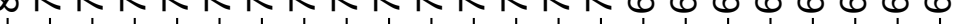

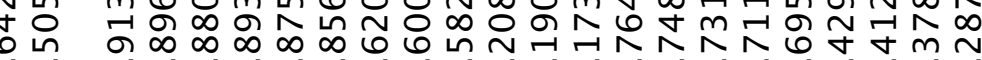

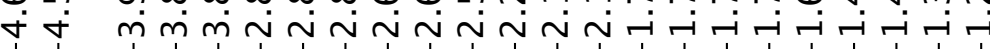

4

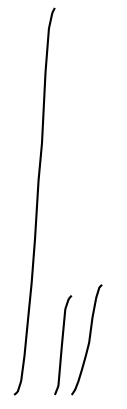<smiles>CCC(C)C(=O)/C=C/[14CH2]Oc1cccc2c1NC(=O)CC2</smiles>

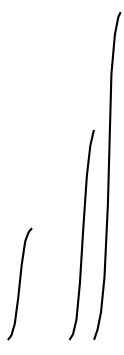

2ag

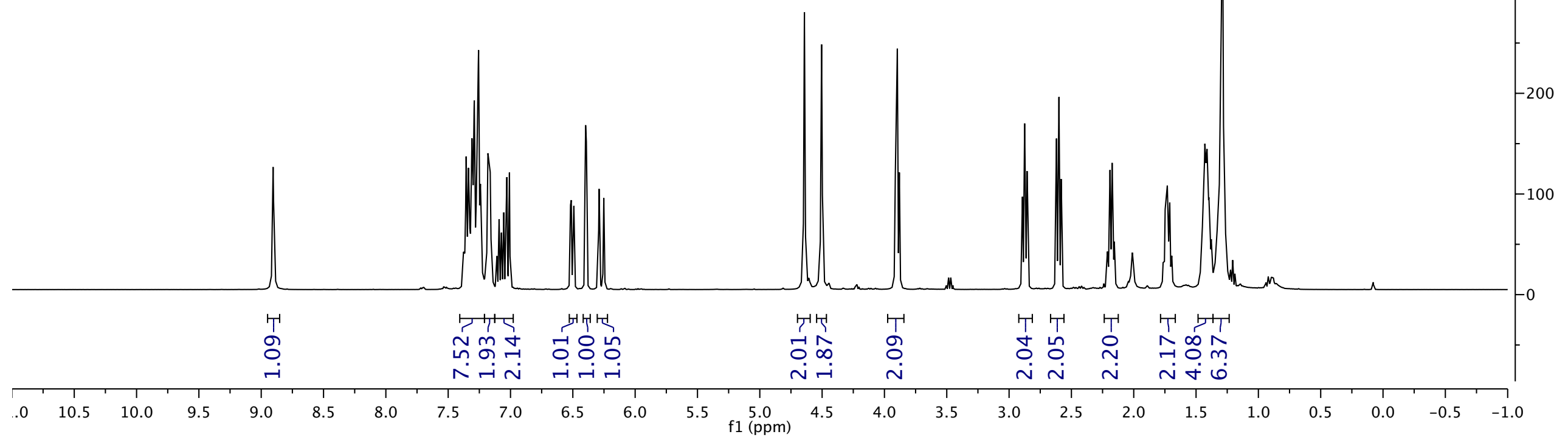




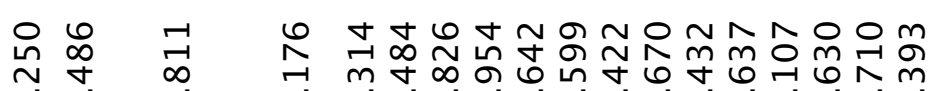

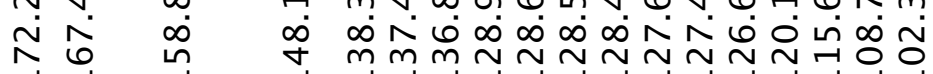

Г

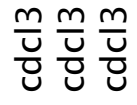

ヘิศ

N

송요

|

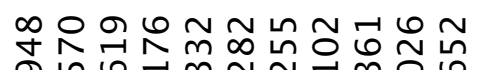

守文<smiles>CCCCC(=O)/C=C/C=COc1cccc2c1NC(=O)CC2</smiles>

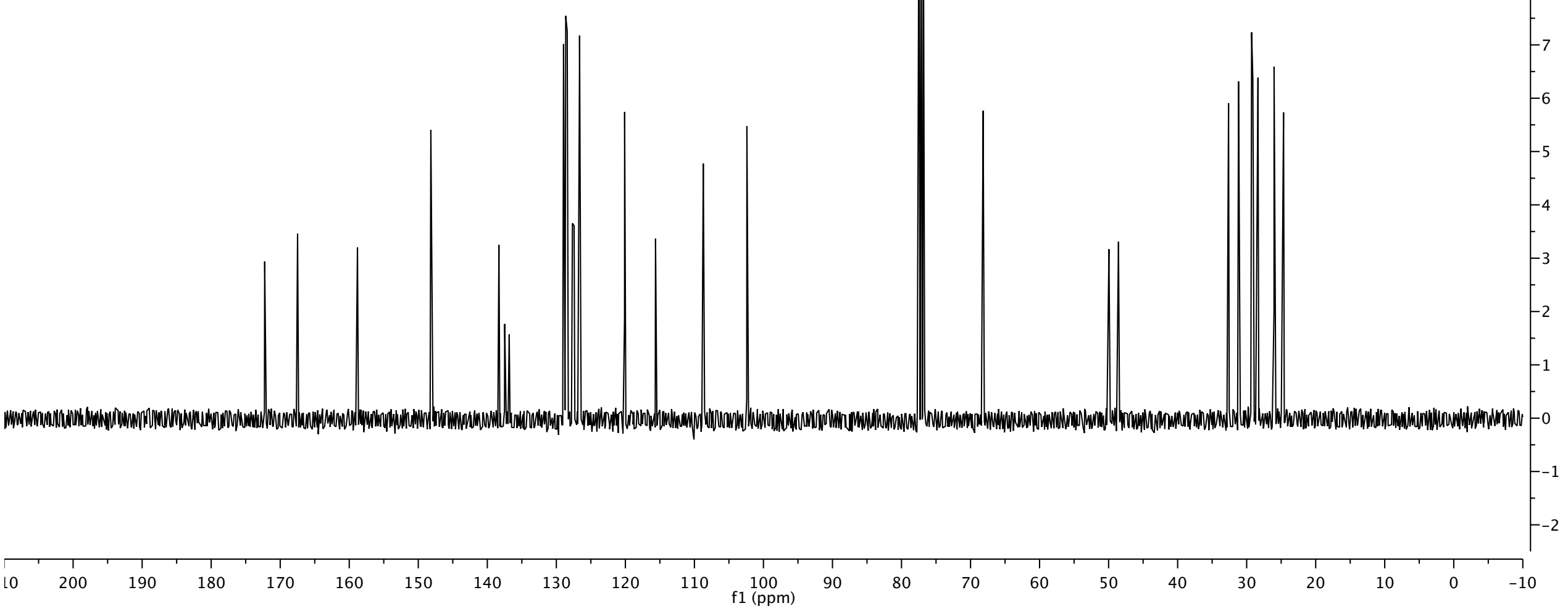



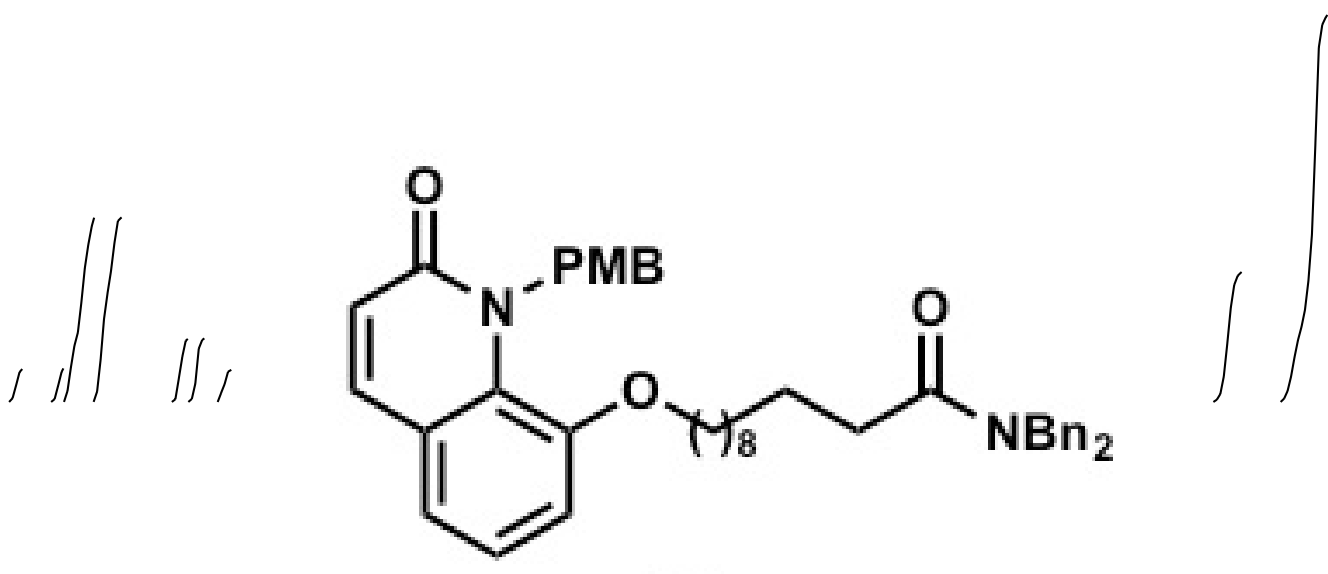

2ah

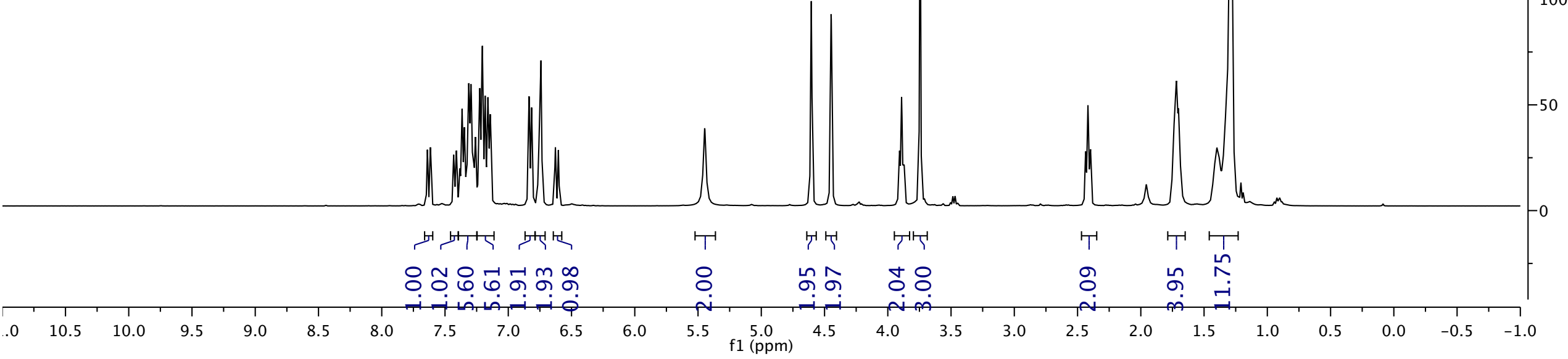



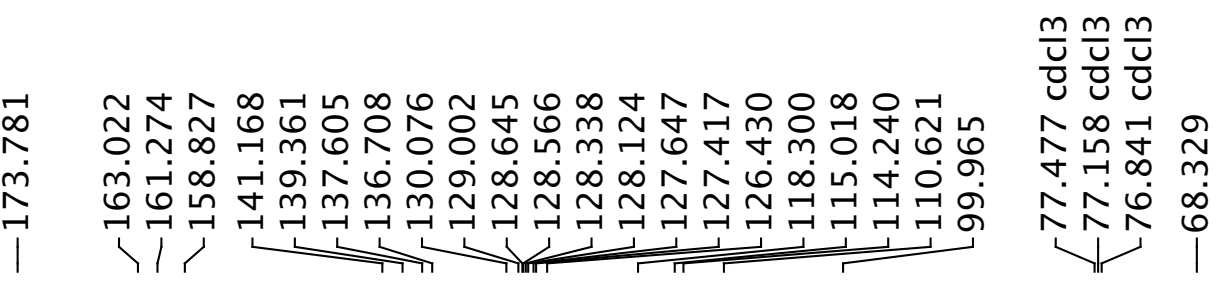

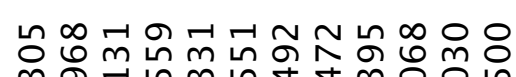

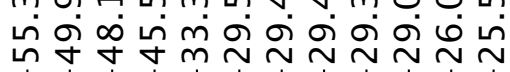<smiles>CCCCC(=O)CCCOc1cccc2ccc(=O)n([PH](C)(=O)=O)c12</smiles>

2ah
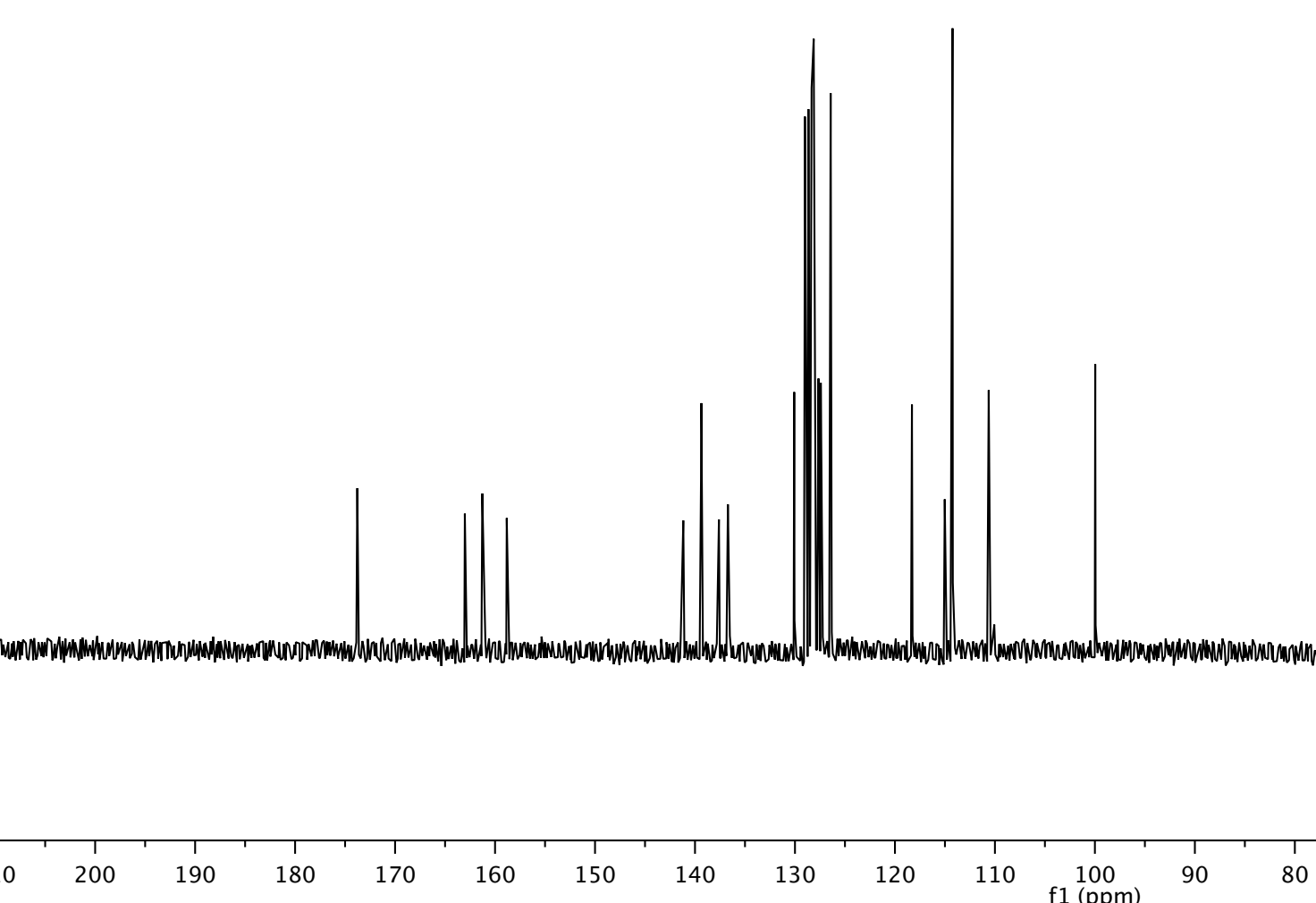


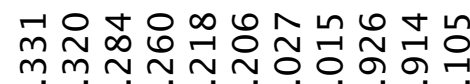

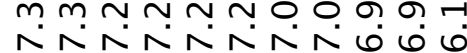

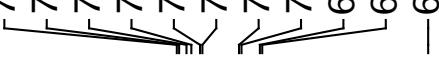

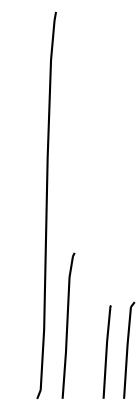

$\stackrel{1}{+2}$<smiles>CC(C)=CC(=O)OCc1ccccc1</smiles>

cis-2ai

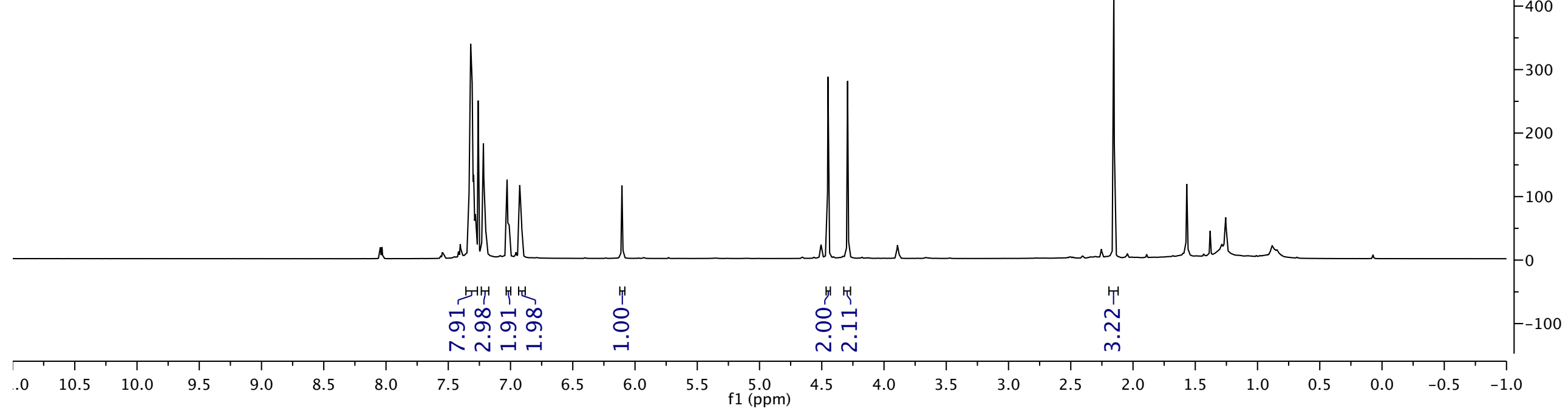




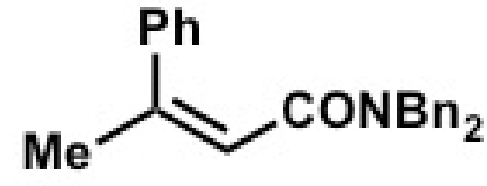

cis-2ai 


\section{trans-2ai}

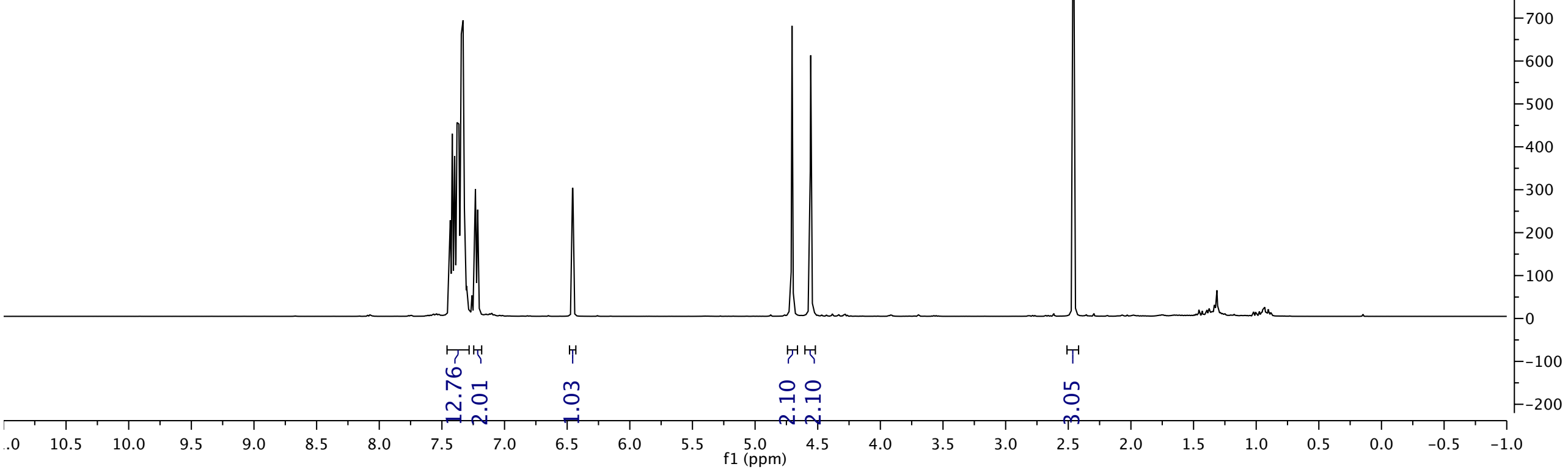


<smiles>C/C(=C\C(=O)OCc1ccccc1)c1ccccc1</smiles>

trans-2ai

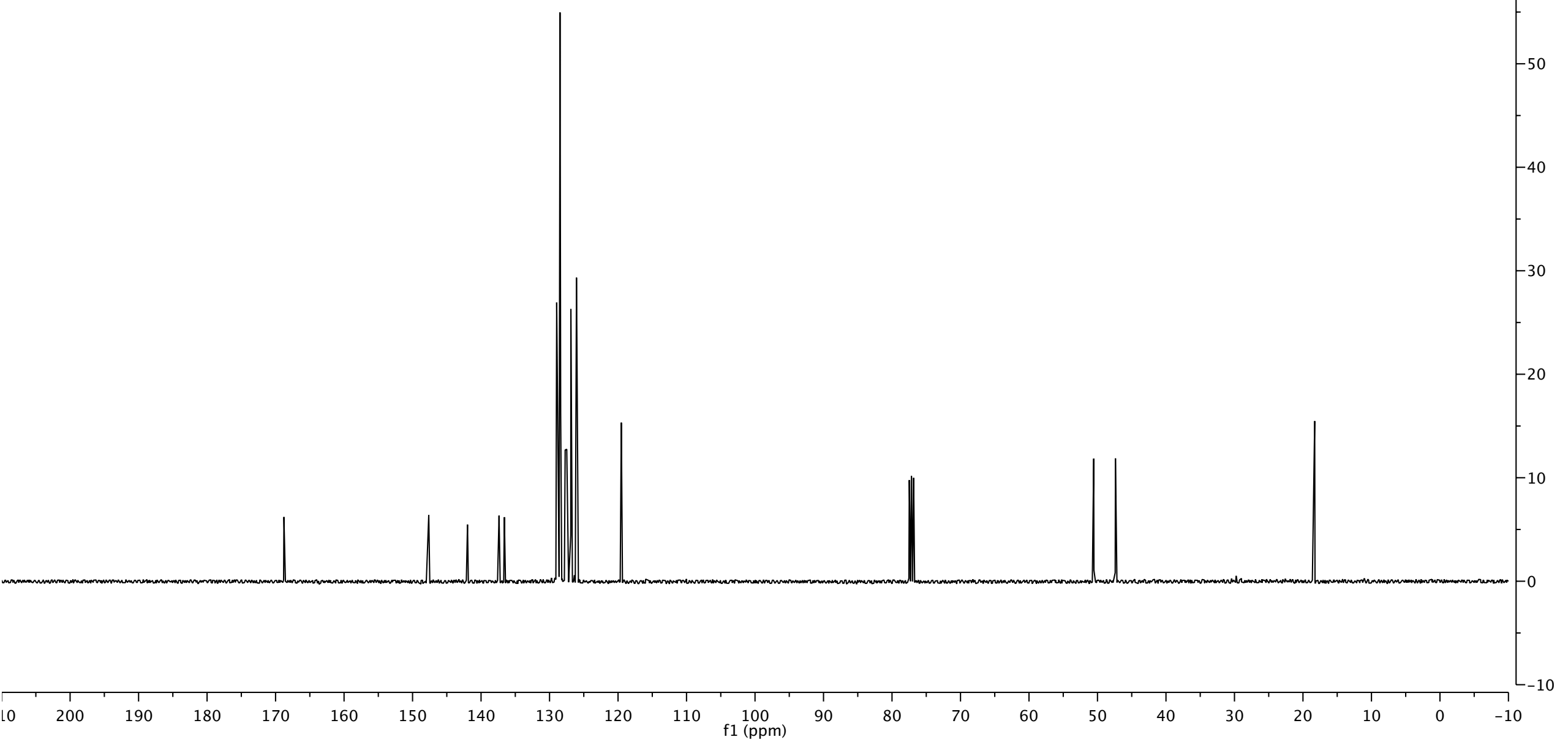



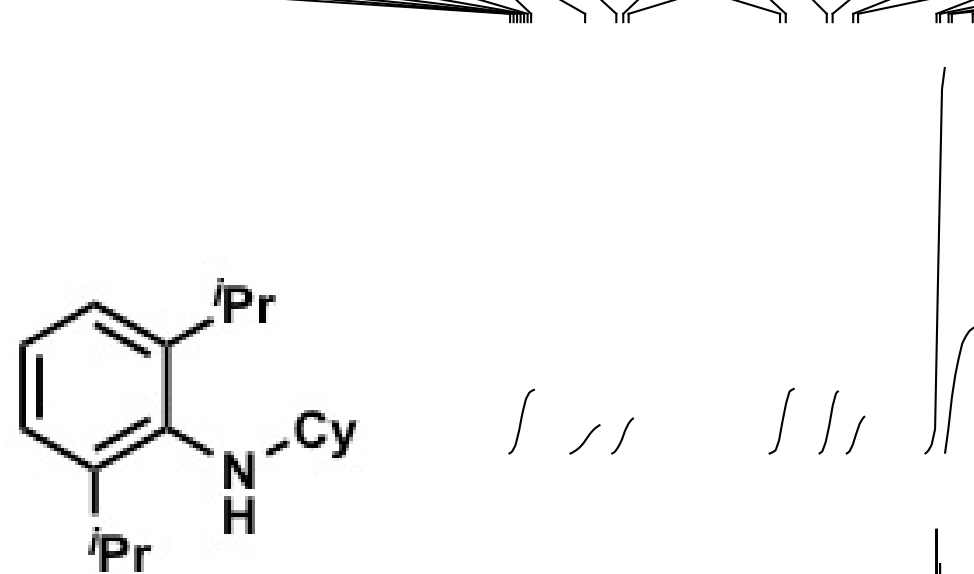

$4 e$

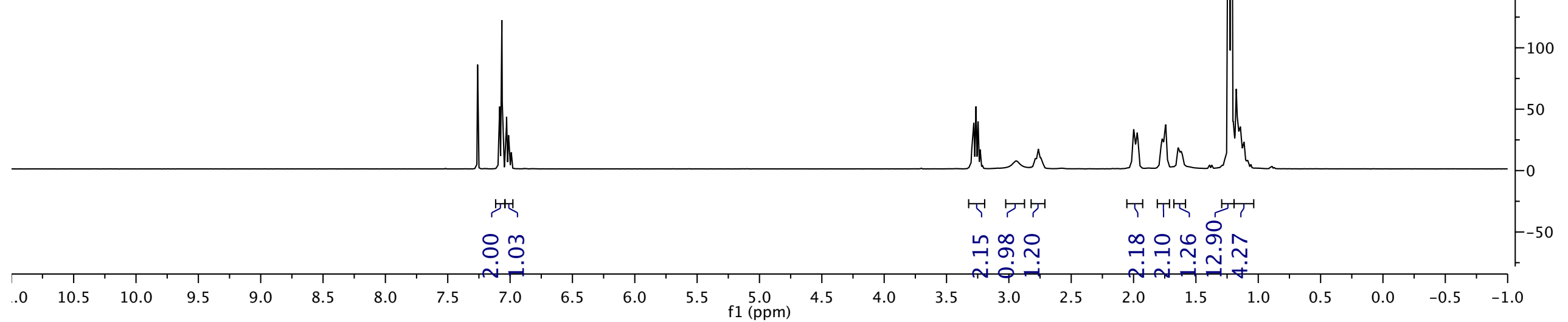




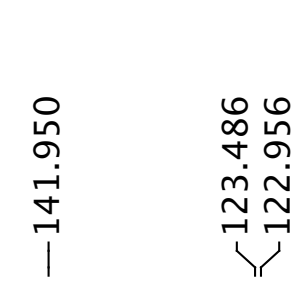

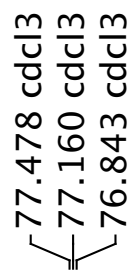
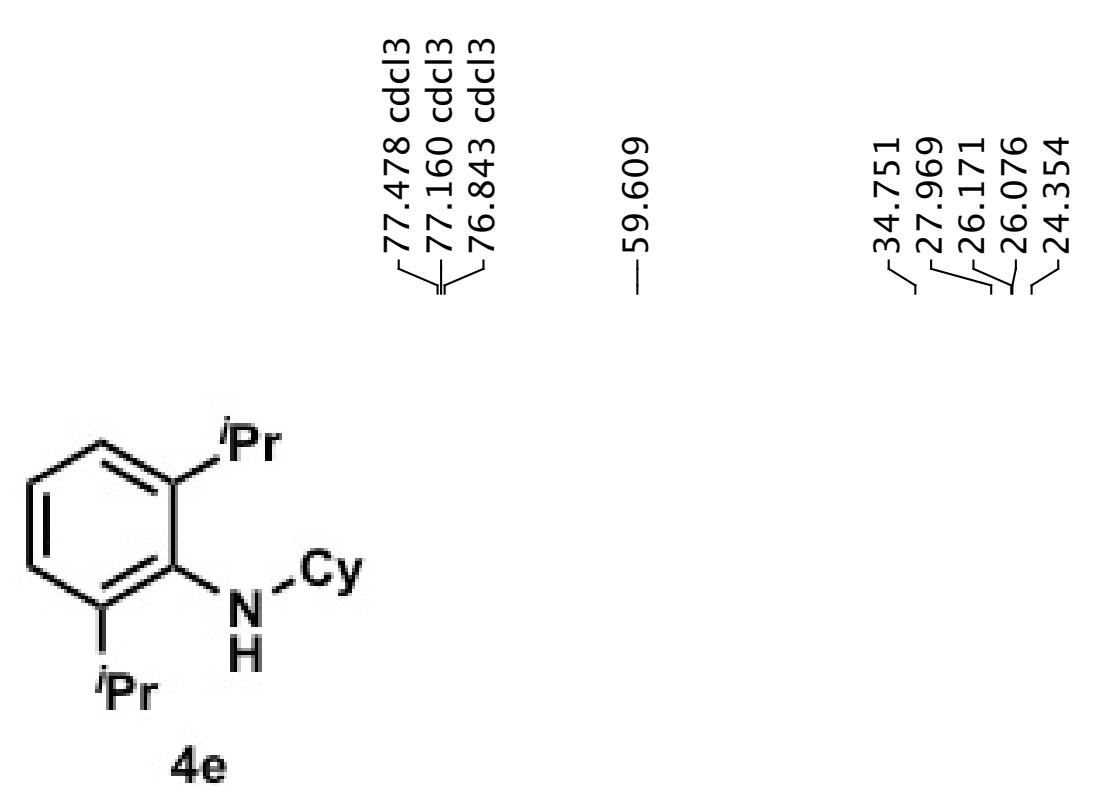

m.

N N 

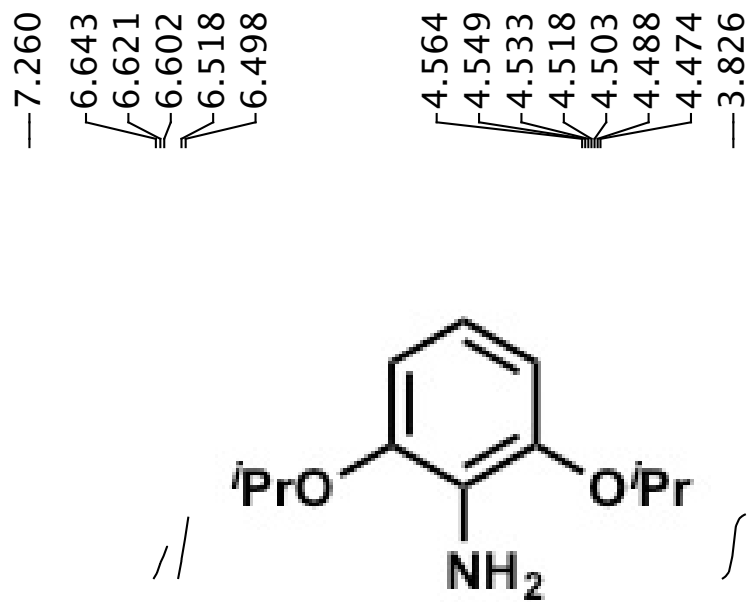

SI-3

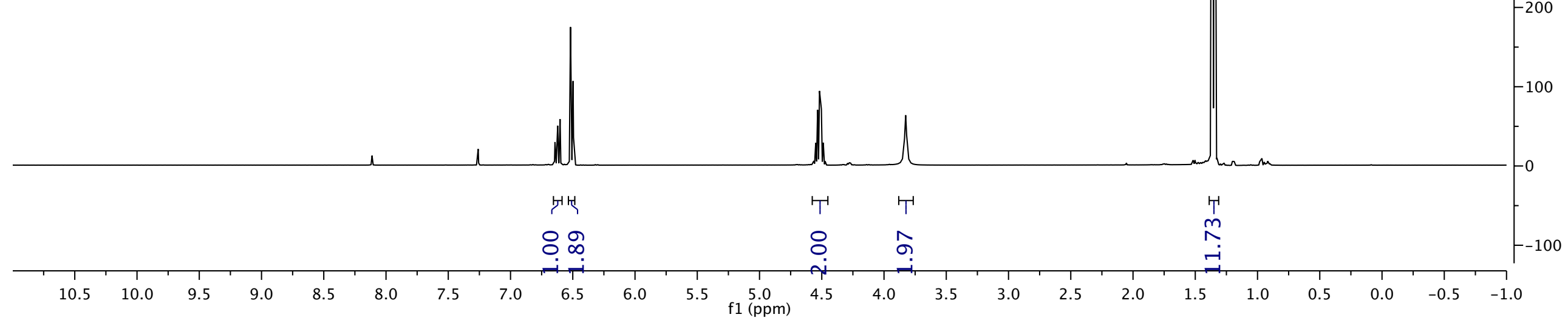




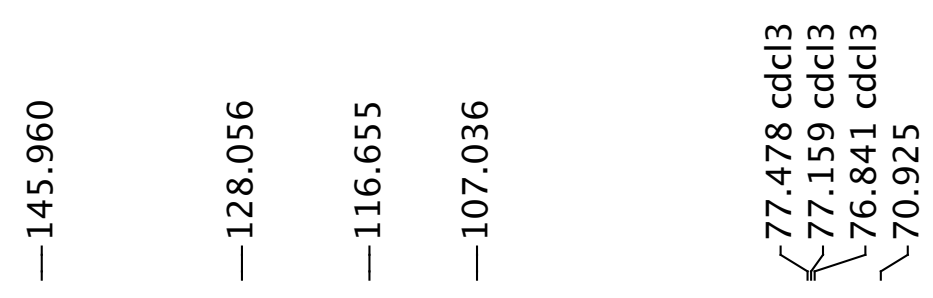

ר్

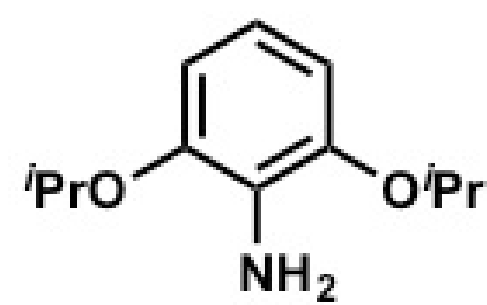

$\stackrel{\sim}{\sim} \underset{\sim}{\sim}$

SI-3

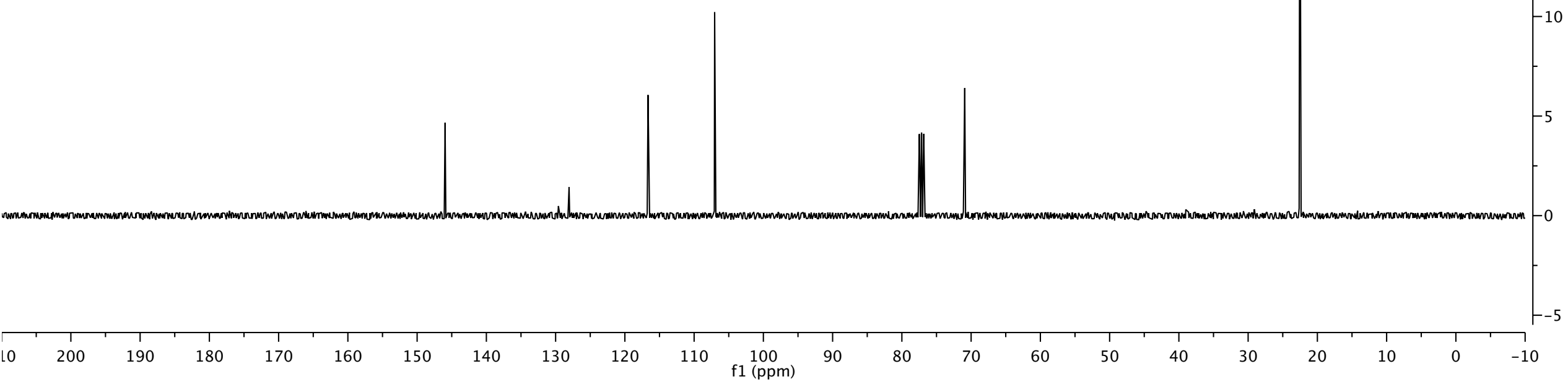




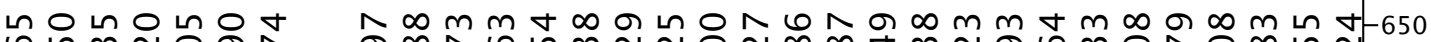

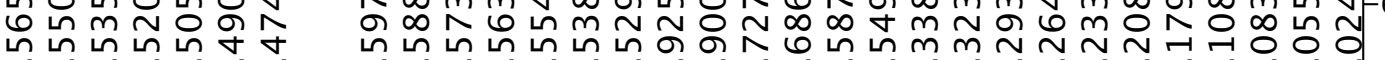<smiles>CCCOc1cccc(OCCC)c1C</smiles>

NHCy

$4 f$
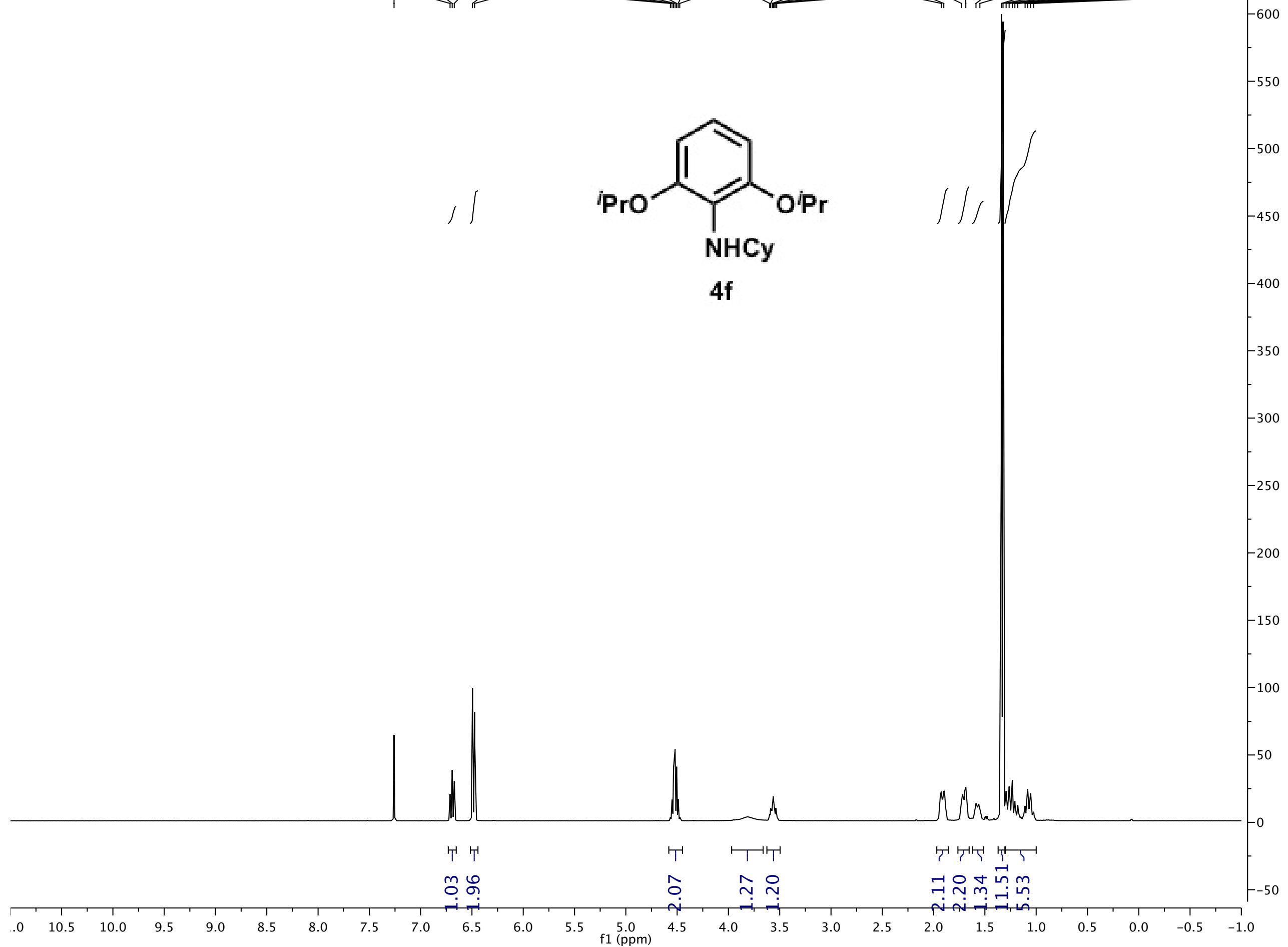


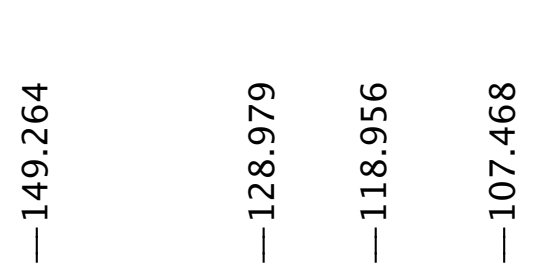<smiles>CCCOc1cccc(OCCC)c1NC(C)C</smiles>

$4 f$ 


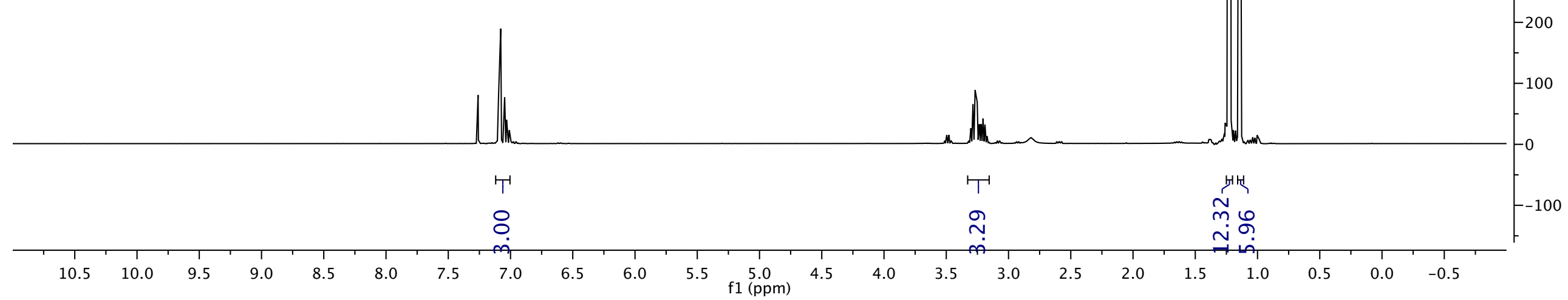



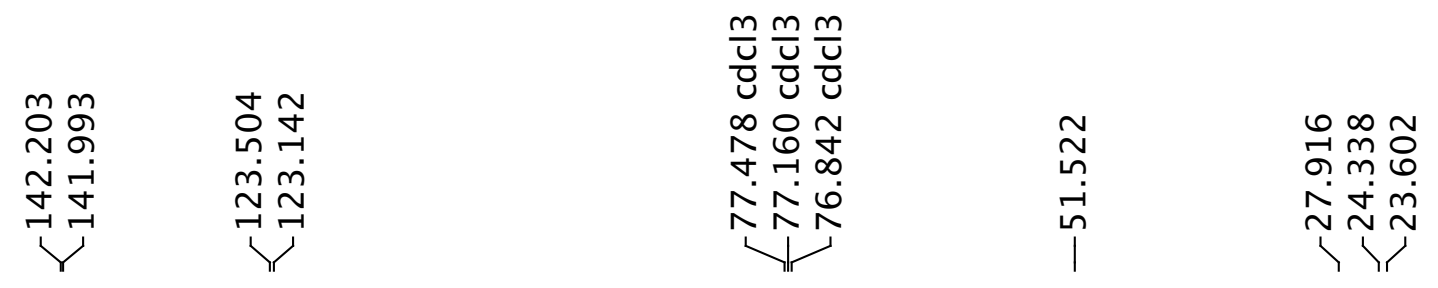<smiles>CC(C)Nc1c(C(C)C)cccc1C(C)C</smiles>

$4 \mathrm{~g}$ 


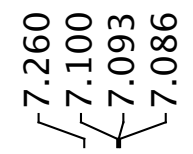

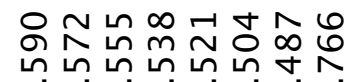

$\dot{m} \dot{m} \dot{m} \dot{m} \dot{m} \tilde{\sim}$

L

نَ
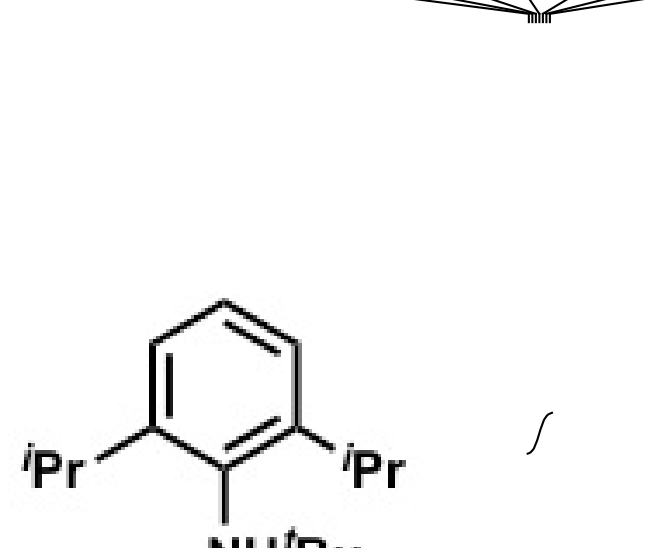

$\mathrm{NH}^{t} \mathrm{Bu}$

$4 \mathrm{~h}$

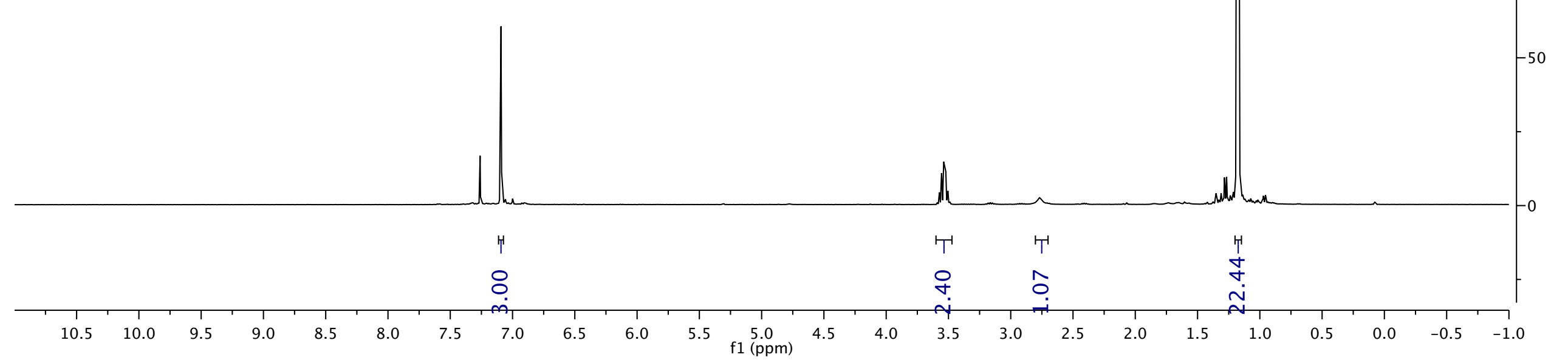




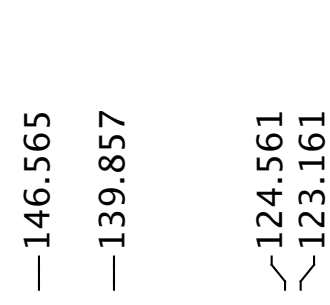

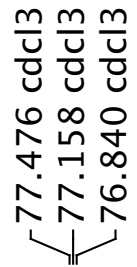

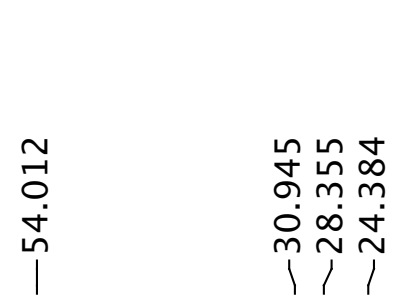<smiles>CCCc1cccc(C(C)C)c1N[R15](C)(C)C</smiles>

4h 


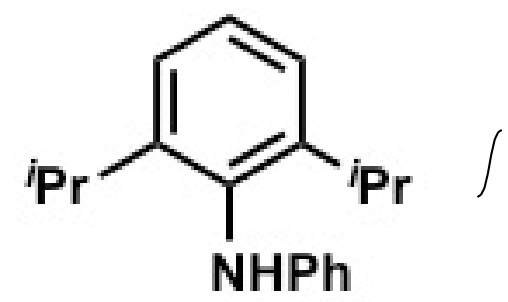

$4 i$

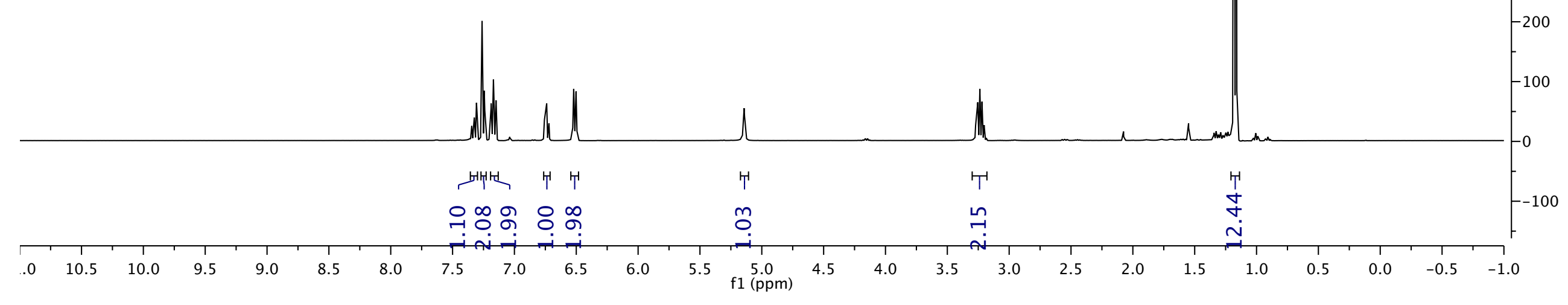



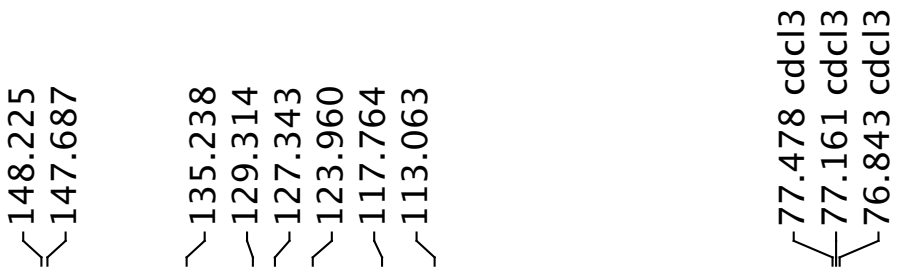<smiles>CCCc1cccc(C(C)C)c1Nc1ccccc1</smiles>

$4 i$

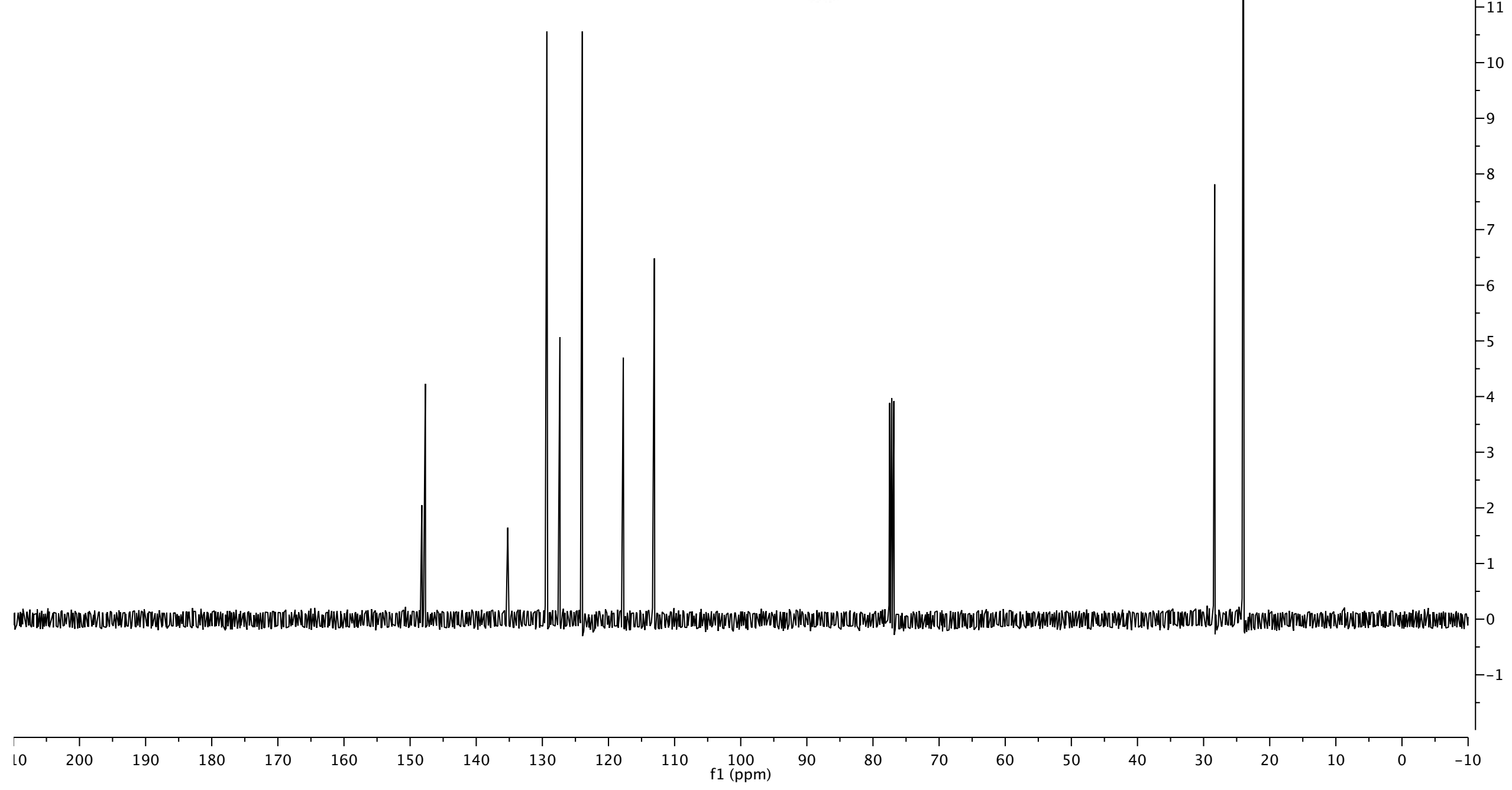

